\title{
Petrographic and Chemical
}

Reconnaissance Study of Some

Granitic and Gneissic Rocks Near

The San Andreas Fault From

Bodega Head to Cajon Pass,

California

$\begin{array}{lllll}\text { GEOLOGICAL SURVEY PROFESSIONAL PAPER } & 698\end{array}$ 
Petrographic and Chemical

Reconnaissance Study of Some

Granitic and Gneissic Rocks Near

The San Andreas Fault From

Bodega Head to Cajon Pass,

California

By DONALD C. ROSS

GEOLOGICAL SURVEY PROFESIONAL PAPER 698

A contribution of the National Center for

Earthquake Research of the Geological Survey

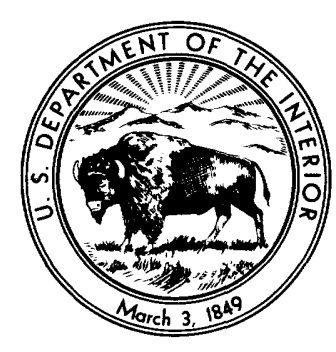

UNITED STATES GOVERNMENT PRINTING OFFICE, WASHINGTON : 1972 


\section{UNITED STATES DEPARTMENT OF THE INTERIOR}

ROGERS G. B. MORTON, Secretary

\section{GEOLOGICAL SURVEY}

V. E. McKelvey, Director

Library of Congress catalog-card No. 72-600089

For sale by the Superintendent of Documents, U.S. Government Printing Office Washington, D.C. 20402

Stock Number 2401--2090 


\section{CONTENTS}

Abstract

Introduction

Basement rocks of the Coast Ranges...............

Central Coast Ranges. ...........................

Quartz diorite of Bodega Head ............ Granitic basement rocks of the Point Reyes area

Setting and general description

Microscopic description

Granodiorite of Point Reyes........

Alaskite and aplite.......

Metamorphic rocks................

Distinguishing features...................

Granodiorite of Southeast Farallon Island . . . -

Granitic rocks of Montara Mountain.........

Basement rocks of the Ben Lomond area ......

Setting and general description.........

Microscopic description................

Quartz diorite of Ben Lomond......

Alaskite of Smith Grade...........

Other rock types.

Distinguishing features..................

Quartz diorite of Cordell Bank . . . . . .

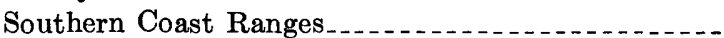

Granitic rocks of the Gabilan Range........

Quartz monzonite of Fremont Peak . .....

Granodiorite of the Gloria-Bickmore Road.

Miscellaneous rocks of the Gabilan Range.

Quartz diorite of Vergeles..........

Granodiorite of Grass and Thompson Creeks

Quartz monzonite of the Gloria-Bickmore Road

Quartz monzonite of the Metz railroad tunnel

Granitic rocks in isolated fault slivers between

the Gabilan Range and Gold Hill

Granitic rocks of Stockdale Mountain ....-

Quartz diorite of Taylor and Varian

Ranches.-.-.........................

Gneissic rocks of Red Hills

Setting and general description

Microscopic description

Gneissic granitic rocks or granitic gneiss _.........................

Augen gneiss. ......................

Miscellaneous rock types.........

Summary of petrographic character of Red Hills gneiss

Granodiorite-quartz monzonite of the La Panza Range

Quartz monzonite of San Juan Creek
Page

1
Basement rocks of the Coast Ranges-Continued Southern Coast Ranges-Continued

Gneiss and alaskite of Barrett Ridge........ Setting and general description......... Microscopic description

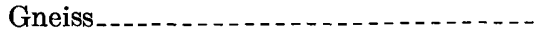

Quartzite (quartz schist) _............

Alaskite and aplite................

Gabbroic rocks of Logan and Gold Hill........

Basement rocks of the Santa Lucia Range ...... -

Petrographic and structural summary of the granitic basement in the Coast Ranges. . . . .

Central Coast Ranges...........

Southern Coast Ranges..........................

Regional considerations . . . . . . . . . . . . . . . .

Implications on the origin of the Salinian block . . . - -

Basement rocks of the Transverse Ranges. . . . . . . .

Biotite granodiorite of Cedar Springs..............

Basement rocks of the Wrightwood-Holcomb area...

Gneiss of the Wrightwood area.......... Granodiorite of Holcomb Ridge............

Rocks structurally transitional between Holcomb and Wrightwood types........

Felsic granodiorite of Largo Vista

Felsic gneiss of Largo Vista . . . . . . . . . .

Gneiss of Pinyon Ridge

Granodiorite of Fairmont Reservoir

Granodiorite of Burnt Peak ......................

Gneissic granitic rocks of Bouquet Reservoir.......

Granitic rocks of Liebre Mountain.......

Granodiorite of the Lebec area.....................

Setting and general description...........

Microscopic description..........

Distinguishing features . . . . . . . . . . . . . .

Alaskite of Brush Mountain

Gabbroic rocks of the Eagle Rest Peak area........

Basement rocks of the Mount Abel-Mount Pinos area. Homogenized gneissic rocks of the central block

Intrusive granitic rocks of the south flank of

Mount Abel-Mount Pinos _.............

Porphyroblastic gneiss of Frazier Mountain . ......-

Contrast between basement rocks of the Mount Abel-Mount Pinos and Frazier Mountain areas.-

Tejon Lookout Granite of Crowell (1952) .........

Granodiorite of Mutau and Piru Creeks.........

Basement rocks of the Mojave Desert in the Lancaster-

Victorville area.....

Granodiorite of Lovejoy Buttes.........

Granodiorites of Hi Vista and Adobe Mountain and

possibly related hybrid rocks of Black Mountain - -

Augite monzonite of Granite Mountain ..........

Miscellaneous granitic rocks of the Mojave region.-.
Page 
Basement rocks of the Mojave-Continued

Miscellaneous granitic rocks, etc. - Continued

Granodiorite of Victorville

Quartz monzonite of the Mojave River and miscellaneous granitic rocks.

Granodiorite of Bell Mountain and miscellaneous dark hybrid(?) rocks. . . . .

Chemical characteristics

Variation diagrams

Page
60
60
60
61
72

Chemical characteristics-Continued

Peacock index

Selected oxide plots $\ldots \ldots \ldots$

Normative mineral plots.................. 83

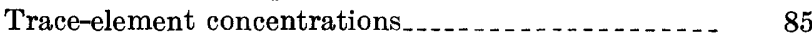

Average chemical composition of biotite and hornblende.

Conclusions. . . .

References cited.

\section{L L U S T R A T I O N}

Plate 1. Map showing generalized geology and sample locations in the granitic and gneissic rocks, central and

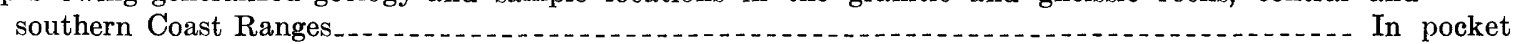

2. Map showing generalized geology and sample locations in the granitic and gneissic rocks, Transverse Ranges and Mojave Desert .

Frgure 1. Map showing exposures of granitic and gneissic basement rocks from Bodega Head to the Cajon Pass area _-.-

2. Histograms showing area of granitic outcrops by rock type in the Coast Ranges

3-15. Triangular diagrams showing modal plots of-

3. Granitic rocks in the Coast Ranges

4. Quartz diorite of Bodega Head.

5. Granitic rocks of the Point Reyes area

7. Granitic rocks of Montara Mountain

8. Granitic rocks of the Ben Lomond area

9. Granitic rocks of the Gabilan Range

10. Granitic rocks of Stockdale Mountain, and Taylor and Varian Ranch fault slivers...............

11. Gneissic 1ocks of Red Hills......

12. Granodiorite and quartz monzonite of the La Panza Range

13. Quartz monzonite of San Juan Creek

14. Alaskite of Barrett Ridge

15. Hornblende quartz gabbro of Gold Hill, Logan, and Eagle Rest Peak areas

16. Map of possible basement slices in the Salinian block

17-31. Triangular diagrams showing modal plots of -

17. Granitic rocks in the Transverse Ranges

18. Biotite granodiorite of Cedar Springs

19. Basement rocks of the Wrightwood-Holcomb area

20. The Pinyon Ridge area...

21. Rocks of Fairmont Reservoir area

22. Gneiss of Bouquet Reservoir area

23. Granitic rocks of Liebre Mountain

24. Granodiorite and related rocks of the Lebec area

25. Rocks in the Mount Abel-Mount Pinos al ea .

26. Rocks on Tejon Peak

27. Granodiorite of Mutau and Piru Creeks.

28. Selected granitic masses, Mojave Desert

29. Granodiorite of Lovejoy Buttes

30. Rocks of Hi Vista, Adobe Mountain, and Black Mountain

31. Miscellaneous granitic rocks in the Mojave Desert

32. Silica-variation diagrams

33-39. Graphs showing-

33. Least-squares line fits of silica-variation diagram data

34. Percentage of various oxides plotted against differentiation index, Coast and Transverse Ranges _.

35. Peacock index of intrusive rocks in the Coast and Transverse Ranges...

36. Peacock index of Coast Ranges granitic rocks_.

37. Peacock index of selected batholithic areas

38. Comparison of percentage of total $\mathrm{Fe}$ as $\mathrm{FeO}$ plotted against $\mathrm{MgO}$ for several granitic suites

39. Comparison of percentage of total $\mathrm{Fe}$ as $\mathrm{FeO}+\mathrm{MgO}$ plotted against $\mathrm{CaO}$ for several granitic suites - - 
FigdRes 40-43. Triangular diagrams showing-

40. Plots of Alk-F-M data

41. Plots of normative quartz, orthoclase, and plagioclase $(\mathrm{Ab}+\mathrm{An})$

42. Plots of normative orthoclase, albite, and anorthite

43. Modes of chemically analyzed specimens, Coast and Transverse Ranges

44. Normative quartz, orthoclase, albite, and anorthite projected to faces of tetrahedron showing mineral phases of the system $\mathrm{Or}\left(\mathrm{KAlSi}_{3} \mathrm{O}_{8}\right)-\mathrm{Ab}\left(\mathrm{NaAlSi}_{3} \mathrm{O}_{8}-\mathrm{An}\left(\mathrm{CaAlSi}_{2} \mathrm{O}_{8}\right)-\mathrm{Q}\left(\mathrm{SiO}_{2}\right)-\mathrm{H}_{2} \mathrm{O}\right.$ at 5,000 bars water pressure - -

45. Histograms showing number of occurrences of "midpoint" trace-element concentration

46. Graphs showing variation of some trace elements with percentage of $\mathrm{SiO}_{2}$

\section{T A B L E S}

TABLES 1-28. Modes of-

1. Quartz diorite and granodiorite of Bodega Head.

2. Granitic rocks of the Point Reyes area_.

3. Granodiorite of Southeast Farallon Island

4. Quartz diorite and felsic rocks of Montara Mountain

5. Granitic rocks of the Ben Lomond area .

6. Granitic rocks of the Gabilan Range

7. Granitic rocks of Stockdale Mountain and fault slivers of Taylor and Varian Ranches

8. Gneissic rocks of Red Hills.

9. Granodiorite-quartz monzonite of the La Panza Range

10. Quartz monzonite of San Juan Creek

11. Alaskite of Barrett Ridge

12. Hornblende quartz gabbro of Logan

13. Honrblende quartz gabbro of Gold Hill

14. Biotite granodiorite of Cedar Springs

15. Basement rocks of the Wrightwood-Holcomb area.

16. Rocks of Pinyon Ridge.

17. Rocks of Fairmont Reservoir area

18. Gneiss of Bouquet Reservoir

19. Rocks of Liebre Mountain

20. Granodiorite and related masses of the Lebec area

21. Hornblende quartz diorite-quartz gabbro of Eagle Rest Peak locality

22. Basement rocks of the Mount Abel-Mount Pinos area

23. Granitic rocks on Tejon Peak

24. Granodiorite of Mutau and Piru Creeks

25. Granodiorite of Lovejoy Buttes

26. Rocks of Hi Vista, Adobe Mountain, and Black Mountain

27. Augite monzonite of Granite Mountain

28. Miscellaneous granitic rocks of the Mojave Desert

29. Chemical data on basement rocks of central Coast Ranges.

30. Chemical data on basement rocks of southern Coast Ranges

31. Chemical data on basement rocks of Transverse Ranges and Mojave Desert _...

32. Average chemical composition and structural formulas for biotite and hornblende in basement rocks of the

Coast and Transverse Ranges 


\title{
PETROGRAPHIC AND CHEMICAL RECONNAISSANCE STUDY OF SOME GRANITIC AND GNEISSIC ROCKS NEAR THE SAN ANDREAS FAULT FROM BODEGA HEAD TO CAJON PASS, CALIFORNIA
}

\author{
By Donaid C. Ross
}

\begin{abstract}
This petrographic and chemical study is based on reconnaissance sampling of granitic and related gneissic rock in the California Coast and Transverse Ranges. In the Coast Ranges, granitic rocks are restricted to an elongate belt, the Salinian block, between the San Andreas and Sur-Nacimiento fault zones. These rocks have a considerable compositional range, but are dominantly quartz monzonite and granodiorite. Most of the Salinian block seems to be a structurally coherent basement block of chemically related granitic rocks. However, on both the east and the west sides of the block, gneiss crops out in abundance; these rocks may be structurally separate from the main part of the Salinian block. In the Transverse Ranges, the granitic and related rockls are dominantly of granodiorite composition, and in many areas granitic and gneissic rocks are intimately intermixed.

Chemically the rocks of the California Coast and Transverse Ranges are somewhat intermediate in character between those of the east-central part of the Sierra Nevada batholith and those of the western part of the Sierra Nevada batholith and the southern California batholith. Probably the closest similarity is to the east-central Sierra Nevada rocks, but the rocks of the Coast and Transverse Ranges are somewhat higher in $\mathrm{Al}_{2} \mathrm{O}_{3}$ and lower in $\mathrm{K}_{2} \mathrm{O}$ than Sierran rocks of the comparable $\mathrm{SiO}_{2}$ content.

Granitic basement rocks of the Salinian block are now anomalously sandwiched between Franciscan terranes. The petrographic and chemical data are compatible with the concept that the Salinian rocks were originally part of the great batholithic belt along the west coast, which is exemplified by the Sierra Nevada batholith. It also seems most likely that the Salinian block was transported from somewhere south of the Sierra Nevada batholith by large-scale right-lateral movement along the San Andreas fault zone.
\end{abstract}

\section{INTRODUCTION}

A reconnaissance sampling of granitic and related gneissic basement rocks was undertaken in the California Coast and Transverse Ranges as part of the west coast earthquake investigations of the U.S. Geological Survey. More specifically, this part of the program is concerned with the granitic basement between the San Andreas fault zone and the Sur-Nacimiento fault zone from Bodega Head south to the intersection of the Coast Ranges and the Transverse Ranges (except for the Santa Lucia Range). The region between these fault zones is now commonly referred to as the Salinian block (Compton, 1966, p. 277). Granitic and gneissic rocks were sampled on both sides of the San Andreas fault in the Transverse Ranges to about as far east as Cajon Pass. The areas sampled are shown on plates 1 and 2 and in figure 1.

The principal objective of the field investigations was to examine the granitic and gneissic rocks and to collect rock types that were common and characteristic as well as to collect distinctive rock types that might be useful for basement correlations or for tracing Cenozoic gravel clasts to their source areas.

Laboratory investigations consisted chiefly of the petrographic study of numerous thin sections and stained slabs; the aim of this study was to determine the modal composition of the various basement masses and how these masses relate to one another. About 75 chemical analyses of major elements and spectrographic analyses of trace elements were made for this study. These analyses, plus some 25 made previously, furnish the basis for generalizations about the chemical nature of the Coast and Transverse Ranges granitic rocks and also form a basic block of data that can be used for comparing these rocks with the granitic basement of other areas, particularly the Sierra Nevada and southern California batholiths.

The present study is by no means a comprehensive petrologic and petrochemical study, but is a preliminary attempt to present regional data that can serve as a base on which to build further studies. Very little petrographic data have been available on these rocks, as most previous studies have merely outlined areas of granitic or basement rocks and have made no attempt to subdivide granitic terranes ranging from quartz monzonite to anorthositic gabbro. 


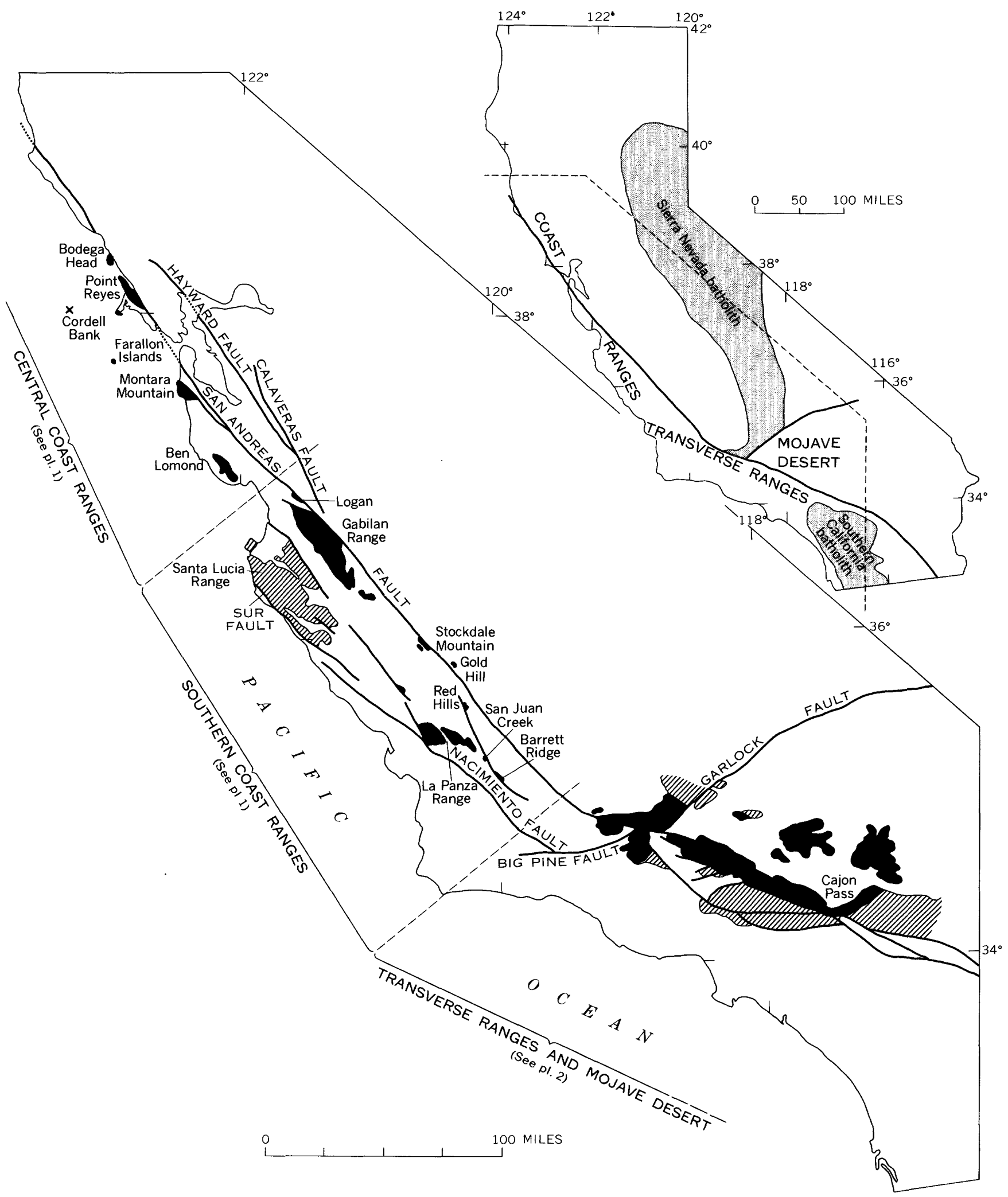

Fraure 1.-Exposures of granitic and gneissic basement rocks from Bodega Head to the Cajon Pass area. Sampled areas shown in solid black. Localities of samples shown on plates 1 and 2. 
One of the major obstacles to deciphering the basement geology of this region, particularly in the Coast Ranges, is the limited exposure of rocks within areas mapped as basement as well as the limited area of basement rock that protrudes through the Cenozoic cover. Within individual basement rock areas it is generally possible to obtain fairly fresh hand-specimen-sized material that is, hopefully, representative. The real difficulty lies in delineating units and determining the relations between rocks of different outcrop areas.

The present study involved very little geologic mapping. Most of the basement rock areas had been reasonably well delineated by earlier workers, and it soon became apparent to me that detailed geologic mapping of any one area would not only be frustrating because of the difficulties in determining rock relations, but would suffer because of the lack of background data to tie into. It was this general frame of thinking that prompted me to a reconnaissance sampling program-the basis for this report.

Each of the numerous basement rock areas is described separately. The format used begins with a general description and the setting of each area, followed by a brief discussion of petrographic features seen in thin section. Finally, for most areas, distinguishing features are noted that might aid in correlation. Petrographic description has been divided into four parts: central Coast Ranges, southern Coast Ranges, Transverse Ranges, and Mojave Desert. The Coast Ranges and the Transverse Ranges are different physiographic provinces, and there is a 40-mile gap in basement rock exposures between them. The division of the Coast Ranges into central and southern is made between Ben Lomond and the Logan-Gabilan outcrops. This is not a natural geologic split, but merely a convenience for grouping the data. The data in this report represent field collections made through September 1969.

\section{BASEMENT ROCKS OF THE COAST RANGES}

About 450 square miles of granitic basement rocks are exposed in the Coast Ranges from Barrett Ridge north to Bodega Head. Metamorphic rocks are present in most granitic areas as inclusions or pendants. These consist mostly of marble and less commonly of schist, quartzite, amphibolite, and gneiss. Marble is particularly abundant in the northern part of the Gabilan Range.

Exposures in the Coast Ranges have been divided for convenience into central and southern parts. In the central Coast Ranges, outcrops occur at Bodega Head, Point Reyes, in the Farallon Islands, at Montara Mountain, Ben Lomond, and Cordell Bank. The major granitic types in these six areas seem to be grossly similar enough to suggest that they represent a closely related granitic suite. In the southern Coast Ranges, outcrops are found in the Gabilan Range, at Stockdale Mountain, in the Red Hills, La Panza Range, at San Juan Creek, and Barrett Ridge, as well as in some other small basement slivers in the San Andreas fault zone. These granitic rocks are generally more felsic than those of the central Coast Ranges, and as can be seen from figure 2, they are dominantly quartz monzonite and granodiorite, whereas the granitic rocks of the central Coast Ranges are dominantly quartz diorite. Some evidence suggests that the La Panza, Stockdale Mountain, and San Juan Creek exposures represent a single mass, or one group of closely related rock types. Also, the gneissic rocks of Barrett Ridge and Red Hills may be part of a gneissic basement separated from the La Panza granitic basement by the Red Hills-San JuanChimeneas fault.

The hornblende quartz gabbro and anorthositic gabbro of Logan and Gold Hill are markedly different from the other granitic rocks of the Coast Ranges (Ross, 1970). Both occurrences may be rootless fault horses, whose point of origin is unknown. They may or may not be part of the Coast Ranges basement and for this reason are discussed separately.

A composite plot (fig. $3 A$ ) of more than 200 modes of the granitic rocks of the Coast Ranges shows a rather good linear trend across the quartz monzonite, granodiorite, and quartz diorite fields and further shows that quartz is abundant and relatively constant over the entire compositional range. The separate plots of central and southern Coast Ranges modes (figs. $3 B, 3 C$ ) have essentially the same trend as the composite plot, but the southern Coast Ranges plot shows some decrease in quartz in the more plagioclase-rich rocks. The composite plot (fig. $3 A$ ) does not show all the points plotted in figures $3 B$ and $3 C$. The Ben Lomond modes of Leo (1967) in figure $3 B$ were omitted from the composite plot. I felt that these modes plus the ones I made from the same area would overwhelm the composite plot with Ben Lomond data. The gabbro modes from Gold Hill and Logan in figure $3 C$ were also omitted from the composite plot as they probably are exotic fault slivers that do not belong to the Salinian block basement. Comparison of this composite plot (fig. $3 A$ ) with one for the Transverse Ranges (fig. 17) shows some differences. In the Transverse Ranges plot, the slope of the trend line to less quartz in the more plagioclase-rich rocks is greater, and there is a tailing off of modes into the diorite field. In addition, the whole field is somewhat displaced toward less quartz. It also appears that the Transverse Ranges rocks are dominantly granodiorite in contrast to the rocks of the Coast Ranges that appear to be more evenly spread across the compositional range 

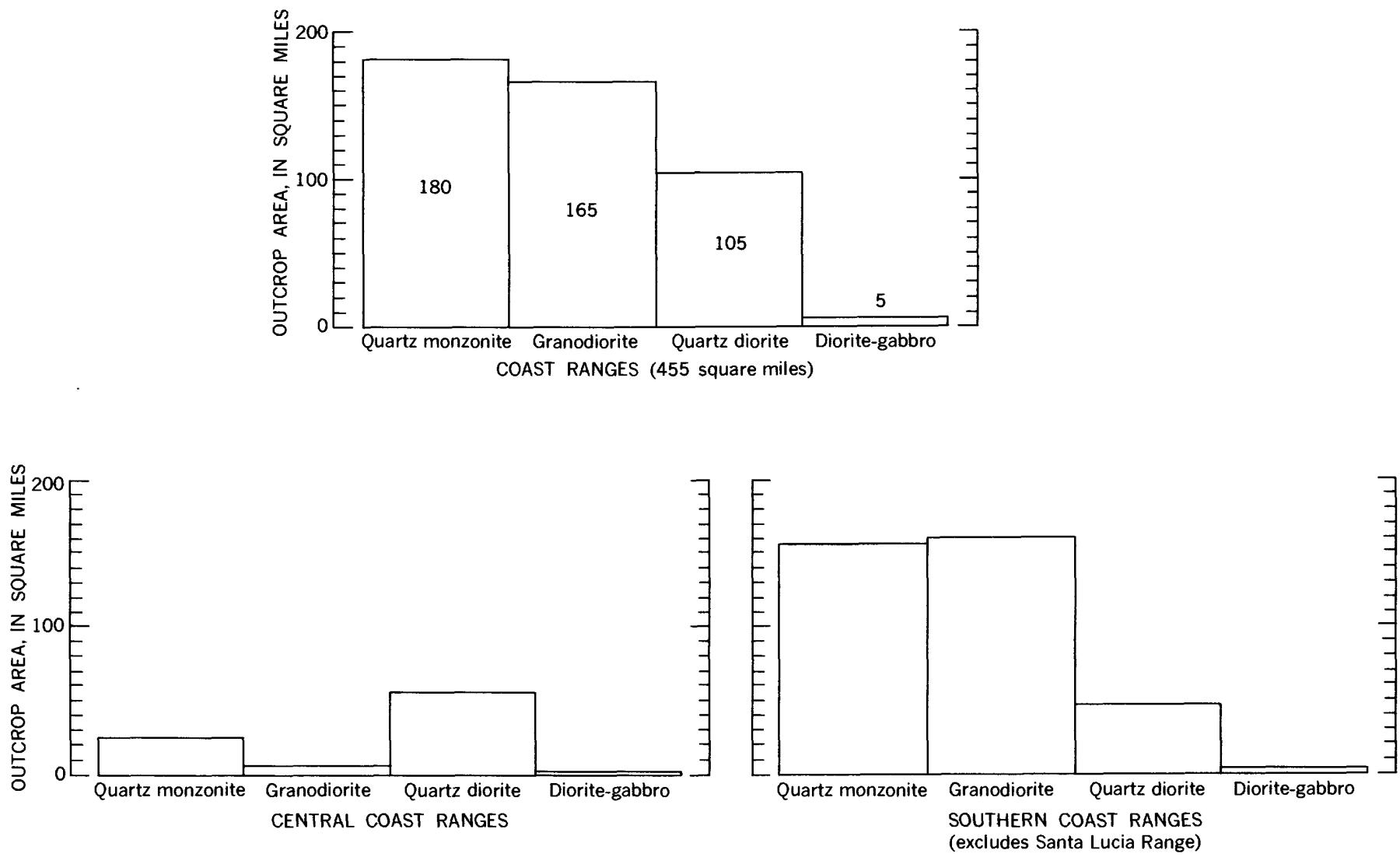

Frauke 2.-Area of granitic outcrops by rock type in the Coast Ranges

from quartz diorite to quartz monzonite. These composite plots probably give a good indication of the gross field and trend of the modal data, but it should be kept in mind that sample density varies considerably. In general, larger areas like the Gabilan and La Panza Ranges were not sampled as extensively as smaller areas like Southeast Farallon Island.

The nearly "horizontal" trend of Coast Ranges modes contrasts with modal averages that have been published for rocks of the Sierra Nevada. The modal trend of rocks of the eastern Sierra Nevada (Bateman, 1965, p. 102) is markedly tilted toward the diorite corner, and the trend of western Sierra Nevada rocks (Ross, 1958, p. 10) is also slanted, but not as much. The generally "horizontal" trend of the Coast Ranges modes suggests that those rocks in the quartz diorite field with abundant quartz might be trondhjemites. Johannsen (1932, p. 383-387) compiled modes and analyses that indicate trondhjemites from the type area in Norway are characterized by about one-third quartz, two-thirds plagioclase (mainly oligoclase), no more than 10 percent biotite, and traces of $\mathrm{K}$-feldspar and amphibole. The quartz diorites of the Coast Ranges in contrast have andesine plagioclase and generally both biotite and hornblende in abundance. Chemically the Norwegian trondhjemites are characterized by high soda (4-6.5 percent) as well as combinations of high silica with high lime and high soda with low $\mathrm{K}_{2} \mathrm{O}$. This is not the chemical pattern of the quartz diorites of the Coast Ranges.

I think it is important to emphasize that in the Coast Ranges there is a wide range of rock types and that in the exposed areas I have sampled, quartz monzonite and granodiorite are dominant (fig. 2). The addition of the Santa Lucia rocks, on the basis of Compton's data (1966) and my brief field examination, probably would give a picture of about equal amounts of quartz diorite, granodiorite, and quartz monzonite for the exposed Coast Ranges granitic basement.

\section{GENTRAL COAST RANGES}

\section{QUARTZ DIORITE OF BODEGA HEAD}

\section{SETTING AND GENERAL DESGRIPTION}

Granitic rocks are exposed for an area of less than 2 square miles at Bodega Head. Although small, this exposure is important, because it is the northernmost land outcrop of granitic rock west of the San Andreas 


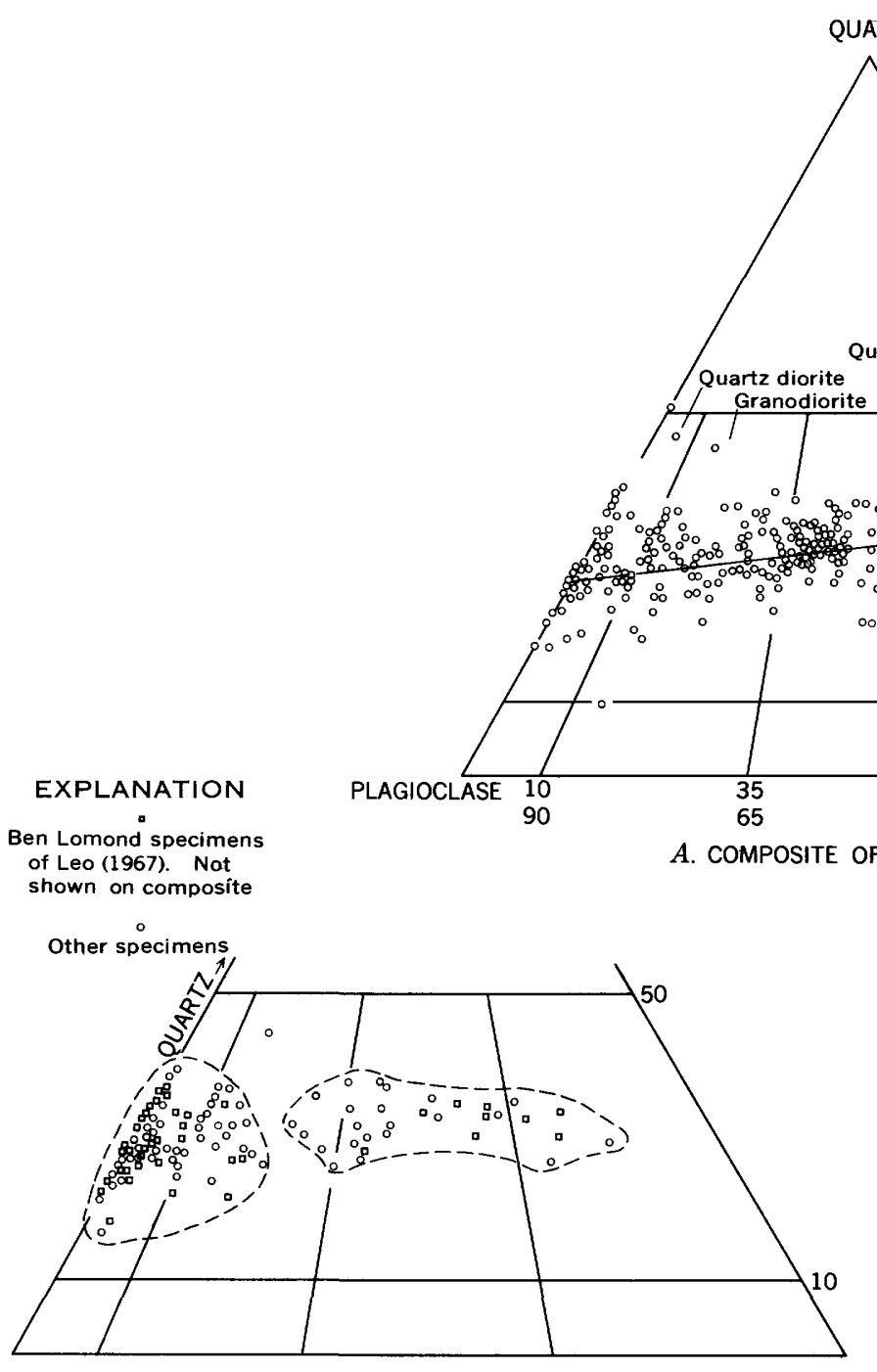

B. CENTRAL COAST RANGES
QUARTZ

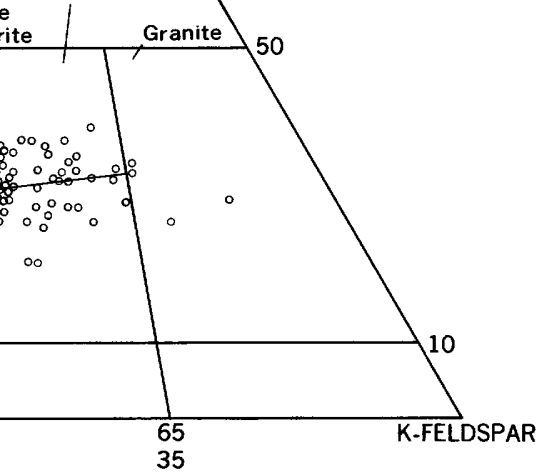

RANGES
EXPLANATION

Logan and Gold Hill specimens. Not shown on composite

Other specimens

Figure 3.-Composite modal plots of granitic rocks in the Coast Ranges.

fault. The width of the San Andreas fault zone here is uncertain, but almost surely the granitic basement butts against the west side of the zone.

The granitic rock is white to light gray with abundant black mottling of biotite and homblende. Dark mineral content varies considerably, but similar primary foliation, general appearance, and local visible variation indicate that all the granitic rocks of Bodega Head are part of one intrusive mass. Foliation is well developed and is shown both by well-alined dark minerals and by elongate dark inclusions and schlieren, which are locally very abundant. The foliation is generally northwesterly and steeply dipping, but at both the north and south ends of the area, foliation is northeasterly and vertical. Aplite, alaskite, and simple pegmatite dikes and pods are present, but not abundant. At the north end of the outcrop area one irregular- shaped pegmatite dike several feet thick contains crystals as large as 1 foot across of quartz, $K$-feldspar, and sodic plagioclase.

$\mathrm{K}$-feldspar is virtually absent in the north half of the area, but makes up as much 10 percent of the rock exposed in beach cliffs to the south. In stained slabs the $\mathrm{K}$-feldspar seems to be concentrated, almost lenslike, parallel to the foliation. In outcrops also, pinkish Kfeldspar seems to be in lenslike segregations, rather than evenly distributed. Thin veinlets of K-feldspar, associated with as well as separated from pegmatite dikes, point to mobility of late $\mathrm{K}$-feldspar in these rocks. Some beach cobbles have relatively well-formed salmon-pink $\mathrm{K}$-feldspar phenocrysts that are as much as 10 millimeters long, but no porphyritic rocks have been seen in place at Bodega Head.

Shear zones from a fraction of an inch to several 
feet wide are conspicuous, as are joints; some parallel the northwest-trending foliation, but they also occur in other orientations. These zones contain chloritic, clayey, and broken granitic material and commonly weather as slots in the sea cliffs. Dikes of pegmatite and inclusions are cut off by some of these zones; so there has been movement along them. Some zones show offsets of a few inches or feet, but for some, the offset dike segments cannot be found, and magnitude of movement is unknown.

Figure 4 and table 1 show the modes of representative samples of Bodega Head granitic rock. The average composition of these rocks is quartz diorite, but some are granodiorite. They have a hornblende-to-biotite ratio of about $1: 1$. The data in figure 4 point out the abundance of total dark minerals as well as of hornblende. The rocks contrast sharply with the nearest granitic rocks to the south, at Tomales Point, where hornblende and total dark minerals are significantly less abundant except near the north end of Tomales Point.

\section{MICROSCOPIC DESGRIPTION}

The texture of these rocks is typically granitic, ranging from xenomorphic- to hypautomorphic-granular. The appearance is decidedly ragged, however, mostly from the irregular dark minerals in a foliated fabric.

Plagioclase is well twinned, generally fresh, and zoned mostly within the sodic andesine range. Some plagioclase crystals have relatively fresh cores that are peppered with small hornblende and biotite crystals. These cores are surrounded by a zone of sericitic and epidote alteration, which in turn is surrounded by a clean rim. All zones are in optical continuity.

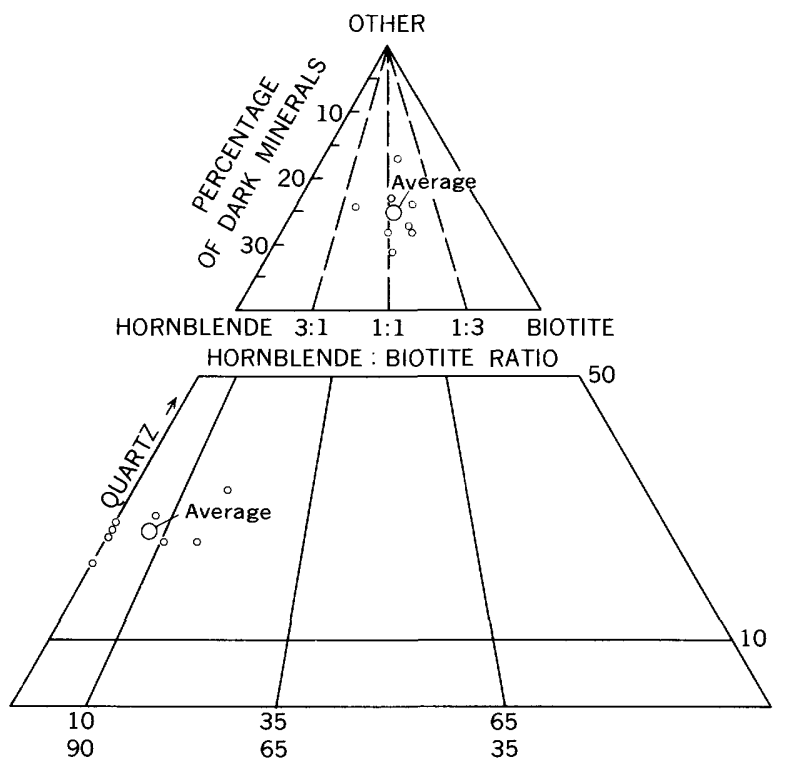

PLAGIOCLASE

K-FELDSPAR

FIgure 4.-Modal plot of quartz diorite of Bodega Head.
TABLE 1.-Modes of quartz diorite and granodiorite of Bodega Head

\begin{tabular}{|c|c|c|c|c|c|c|}
\hline No. & $\begin{array}{l}\text { Plagio- } \\
\text { clase }\end{array}$ & $\begin{array}{l}\text { K-feld- } \\
\text { spar }\end{array}$ & Quartz & Biotite & $\begin{array}{l}\text { Horn- } \\
\text { blende }\end{array}$ & $\begin{array}{l}\text { Specific } \\
\text { gravity }\end{array}$ \\
\hline $\begin{array}{r}\text { D R-505 } \\
506 \\
507 \\
508 \mathrm{~A} \\
509 \\
510 \mathrm{~A} \\
511 \mathrm{~A} \\
512 \ldots \\
\end{array}$ & $\begin{array}{l}48 \\
46 \\
50 \\
52 \\
53 \\
53 \\
54 \\
52\end{array}$ & $\begin{array}{r}9 \\
10 \\
4 \\
6 \\
<1 \\
<1 \\
<1 \\
<1\end{array}$ & $\begin{array}{l}19 \\
27 \\
22 \\
19 \\
20 \\
19 \\
15 \\
20\end{array}$ & $\begin{array}{r}8 \\
10 \\
15 \\
12 \\
16 \\
14 \\
16 \\
17\end{array}$ & $\begin{array}{r}16 \\
7 \\
9 \\
11 \\
11 \\
14 \\
15 \\
11\end{array}$ & $\begin{array}{l}2.71 \\
2.72 \\
2.75 \\
2.75 \\
2.75 \\
2.77 \\
2.77 \\
2.75 \\
\end{array}$ \\
\hline Average . . . . . . & 51 & 4 & 20 & 13 & 12 & 2.75 \\
\hline
\end{tabular}

K-feldspar, even where present in only trace amounts, commonly engulfs other minerals. Where fairly abundant, it forms lenslike lacy concentrations (poikilocrysts) similar to those noted on a larger scale in outcrop.

Quartz is abundant in these rocks and about as common in rocks with no K-feldspar as in those with abundant K-feldspar. Some quartz has apparently replaced plagioclase, leaving scalloped, embayed boundaries with plagioclase crystals. Despite the prominent foliation of this rock and the abundant shear zones, quartz generally does not appear unduly strained. Most shows undulatory extinction, but sutured mosaics of quartz crystals, and granulation are only present locally.

Biotite is in ragged, irregular crystals. Most is relatively unaltered, but specimen 505 contains intensely chloritized biotite accompanied by trains of sphene droplets in the chlorite paralleling the original biotite cleavage. The pleochroism of the biotite is $\mathbf{X}=$ grayish yellow to grayish orange and $Z=$ moderate brown to dark yellowish brown. This is notably in contrast to the generally reddish brown color of many of the biotites immediately to the south in the Point Reyes area.

Hornblende is also irregular in habit and generally unaltered. It is about as abundant as biotite and commonly associated with it. The pleochroism is similar throughout Bodega Head: $\mathrm{X}=$ moderate greenish yellow, $\mathrm{Y}=$ light olive, and $\mathrm{Z}=$ moderate yellowish green to grayish green. This pleochroism is generally similar to that of the hornblende of the Point Reyes area.

Apatite and zircon are the most common accessory minerals; allanite is rare. All the specimens contain scattered tiny irregular crystals and sparse stringers and trains of tiny sphene grains, but only specimen 508 contains abundant subhedral typical honey-brown crystals that are large enough to be visible to the naked eye. Metallic opaque minerals are present in trace amounts in hornblende, but in specimen 511 they are present in biotite and hornblende in near "normal" amounts. On the whole, both sphene and metallic opaque minerals are uncommon enough to be noteworthy; most sphene oc- 
curs as tiny grains in biotite, and most metallic opaque minerals as tiny grains in hornblende.

Inclusions and schlieren range from medium to fine grained and are darker than the enclosing quartz diorite. Most have an almost aplitic texture that resembles hornfels. In some inclusions, coarser crystals of plagioclase, poikilitic hornblende, and biotite are set in the finer grained aplitic matrix. The plagioclase is well twinned and zoned, generally in the sodic to intermediate andesine range. Quartz is much less abundant in the inclusions than in the enclosing grantitic rocks. Biotite and hornblende are similar to those minerals in the granitic rock and have similar pleochroism. Accessory minerals are also similar to those in the enclosing rocks, except that one specimen has a liberal sprinkling of metallic opaque grains, presumably ilmenite (they are not attracted to a magnet).

One of the more noteworthy characteristics of most of these rocks is that they are virtually unaltered, despite the abundance of shear zones that could have served as channels for later solutions.

\section{DISTINGUISHING FEATURES}

The dark well-foliated quartz diorite of Bodega Head contrasts with the somewhat lighter and less foliated rocks of the Point Reyes area, though the rocks of Tomales Point, nearest to Bodega Head, are similar. The abundant dark dioritic inclusions, in part in swarms, are somewhat atypical of central Coast Ranges granitic rocks.

Brown biotite without red tints is distinct from the reddish-brown biotite that occurs in granitic rocks elsewhere in the central Coast Ranges. Also, the "lenticular" poikilocrysts of $\mathrm{K}$-feldspar are possibly somewhat different from those in other outcrop areas. The rarity of sphene and, especially, magnetite is noteworthy.

\section{GRANITIC BASEMENT ROCKS OF THE POINT REYES AREA}

\section{SETTING AND GENERAL DESCRIPTION}

Granitic rocks are exposed along the west side of the San Andreas fault zone and presumably butt against it for a length of about 18 miles in a southeasterly direction from Tomales Point to the Mount Wittenberg area. Similar rocks also crop out through Tertiary sedimentary deposits at Point Reyes. Inclusions and small roof pendants of schist, quartzite, calc-hornfels, and marble, as well as an unusual cummingtonite amphibolite and a sillimanite-bearing micaceous hybrid(?) rock, are present in the granitic rocks. Dikes and small irregularshaped masses of aplite, alaskite, and less commonly simple pegmatite intrude the granitic rocks.

The granitic rocks of the Point Reyes area vary con- siderably in composition, from quartz diorite to quartz monzonite, as can be seen from figure 5 and table 2 . The average modal composition is granodiorite. Particularly noteworthy are the number of specimens that are quartz monzonite and that have 20 percent or more $\mathrm{K}$-feldspar. The variation appears to be somewhat systematic; the rocks along the northern part of Tomales Point and those of Point Reyes are generally less felsic than those of the Mount Wittenberg area, which have more K-feldspar and less dark minerals. The sparse number of sampled localities permits no more than a hint of a possible bimodal distribution, and there is no way, with the present data, to choose between separate intrusives and one large zoned mass.

TABLE 2.-Modes of granitic rocks of the Point Reyes area [n.d. $=$ not determined]

\begin{tabular}{|c|c|c|c|c|c|c|}
\hline No. & $\begin{array}{l}\text { Plagio- } \\
\text { clase }\end{array}$ & $\begin{array}{l}\text { K-feld- } \\
\text { spar }\end{array}$ & Quartz & Biotite & $\begin{array}{l}\text { Horn- } \\
\text { blende }\end{array}$ & $\begin{array}{l}\text { Specific } \\
\text { gravity }\end{array}$ \\
\hline 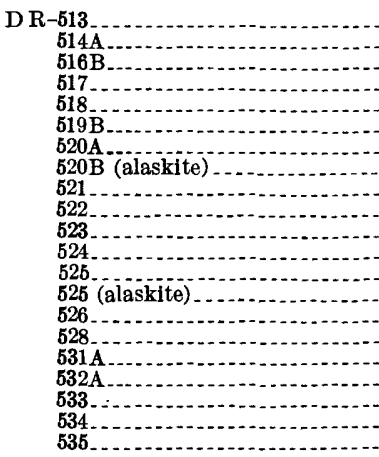 & $\begin{array}{l}39 \\
36 \\
39 \\
48 \\
34 \\
38 \\
37 \\
24 \\
54 \\
53 \\
36 \\
34 \\
47 \\
13 \\
55 \\
36 \\
42 \\
45 \\
51 \\
48 \\
38\end{array}$ & $\begin{array}{r}24 \\
23 \\
26 \\
15 \\
26 \\
22 \\
21 \\
41 \\
1 \\
5 \\
28 \\
25 \\
9 \\
55 \\
1 \\
26 \\
8 \\
18 \\
13 \\
18 \\
25\end{array}$ & $\begin{array}{l}27 \\
28 \\
28 \\
23 \\
35 \\
38 \\
30 \\
34 \\
25 \\
23 \\
30 \\
36 \\
25 \\
29 \\
26 \\
32 \\
41 \\
28 \\
25 \\
31 \\
23\end{array}$ & $\begin{array}{r}10 \\
13 \\
7 \\
12 \\
5 \\
5 \\
12 \\
1 \\
19 \\
15 \\
6 \\
5 \\
13 \\
3 \\
15 \\
6 \\
9 \\
8 \\
11 \\
3 \\
9\end{array}$ & $\begin{array}{r} \\
\\
0\end{array}$ & $\begin{array}{l}2.62 \\
2.60 \\
2.63 \\
2.70 \\
2.62 \\
2.59 \\
2.61 \\
2.60 \\
2.71 \\
2.69 \\
2.63 \\
2.63 \\
2.72 \\
\text { n.d. } \\
2.72 \\
2.63 \\
2.66 \\
2.66 \\
2.67 \\
2.63 \\
2.65\end{array}$ \\
\hline $\begin{array}{l}\text { Average (alaskite not } \\
\text { counted in average) }\end{array}$ & 43 & 17. & 29 & & .5 & 2.65 \\
\hline
\end{tabular}

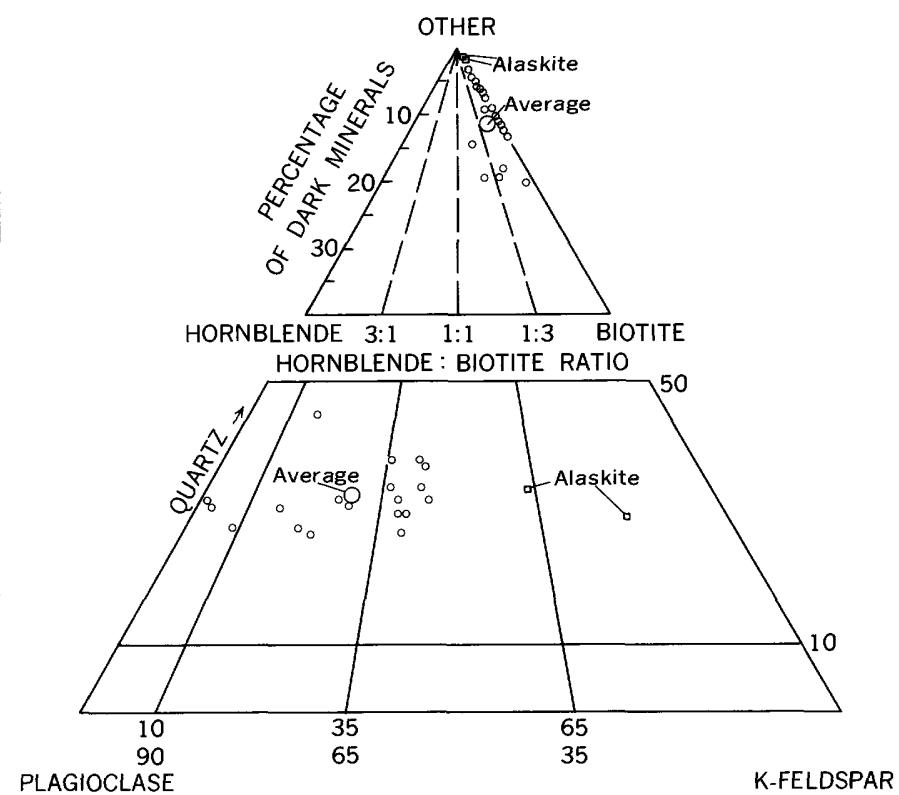

Figure 5.-Modal plot of granitic rocks of the Point Reyes area. 
PETROGRAPHIC, CHEMICAL STUDY, GRANITIC AND GNELSSIC ROCKS, SAN ANDREAS FAULT, CALIF.

These rocks are medium to coarse grained; where fresh, they are white to light gray, and mottled with black biotite and hornblende. Probably the most notable characteristic of hand specimens is the irregular, shredded appearance of the dark minerals. Poikilitic almost lacy $\mathbf{K}$-feldspar crystals locally as long as $30 \mathrm{~mm}$ also accentuate the irregular texture on stained slab surfaces. Foliation is locally shown by elongate dioritic inclusions and mineral elongation; locally some subtle banding also is present.

Intruding the granitic rocks are dikes and masses of aplite and alaskite that commonly weather to shades of yellow and orange. These rocks seem particularly abundant in the Mount Wittenberg area.

\section{MICROSGOPIC DESCRIPTION}

Granodiorite of Point Reyes

The granitic rocks exposed at Point Reyes are generally xenomorphic- to hypautomorphic-granular. Some specimens are in part aplitic, as shown by scattered rounded quartz crystals.

Plagioclase is cleanly twinned and has oscillatory zoning. It ranges in composition from sodic oligoclase to calcic andesine; sodic andesine is probably the average composition. The plagioclase has been altered to sericite in varying degree : from mere traces of sericite, through widespread dusting, to intense replacement. Unaltered sodic rims are noted in some plagioclase crystals, particularly in those that abut $K$-feldspar and much less commonly in those that abut quartz.

$\mathrm{K}$-feldspar ranges from irregular shreds of interstitial grains to large poikilitic masses, commonly engulfing other constituents. Much shows well-developed grid twinning, and some is perthitic, but patchy rather than evenly banded.

Quartz is particularly abundant in these rocks, averaging nearly 30 percent. It is generally as abundant in the quartz diorite as in the quartz monzonite. The quartz is irregular shaped; in some specimens, rounded interstitial grains give the rock an almost aplitic appearance, but in others, where quartz makes up 35-40 percent, though irregular, the quartz can hardly be termed interstitial. That some quartz has replaced plagioclase is shown by embayed and scalloped contacts. Most of the quartz has undulatory extinction and incipient mosaicking, but well developed mosaicked grains with sutured boundaries are rare; the quartz does not reflect undue strain. Myrmekite is locally abundant, particularly in specimens with the rounded quartz grains.

Biotite is characteristically very irregular and commonly shredlike. In the northern part of Tomales Ridge, it is generally in coarser plates, up to $10 \mathrm{~mm}$ across, but is still irregular shaped. The degree of alteration is variable; in some specimens biotite is virtually unaltered, whereas in others chlorite is abundant and associated with stringers of sphene along the cleavage traces. The pleochroism of the biotite is $\mathrm{X}=$ grayish orange to grayish yellow and $Z=$ moderate brown to moderate reddish brown; some dominantly brown biotite has reddish bands.

Hornblende is uncommon in these rocks, except at the north end of Tomales Point and Point Reyes. It is in irregular grains, some of which have lacy margins that include quartz. Also, some small crystals of hornblende are zonally arranged in plagioclase crystals. In one specimen the hornblende is extensively altered to chlorite and epidote, whereas associated biotite is virtually unaltered. Most hornblende, however, is relatively fresh. The pleochroism is $\mathrm{X}=$ moderate greenish yellow, $\mathrm{Y}=$ light olive, and $\mathrm{Z}=$ light olive to grayish and dark yellowish green. Some pale fibrous grains may be actinolite, rather than hornblende.

Apatite and zircon are present in all specimens, and allanite is much less common. Sphene is present only at Point Reyes and on the northern part of Tomales Ridge. It is in irregular grains generally closely associated with or included in biotite. Some sphene appears to be an alteration product of biotite, but in books of seemingly unaltered biotite thin stringers and beadlike trains of sphene grains outline cleavage traces and appear to be primary. Most specimens lack metallic opaque minerals, although trace amounts are included in hornblende and biotite locally. Both sphene and metallic opaque minerals are virtually absent in rocks of the Mount Wittenberg area.

\section{Alaskite and Aplite}

The alaskite and aplite are medium to fine grained and generally have an aplitic texture marked by rounded quartz grains. Petrographically they have little to distinguish them. Thinly twinned plagioclase ranges from albite to andesine. Grid-twinned $\mathrm{K}$-feldspar is particularly abundant. In some obviously sheared zones, quartz displays mortar structure, but elsewhere quartz with undulatory extinction shows little evidence of strain. Biotite is sparse and scattered; in part it is pleochroic in reddish shades and in part in shades of orange and brown. These rocks contain apatite and zircon, and one specimen contains very small amounts of sphene and metallic opaque minerals.

\section{Metamorphig Rogks}

Schist, micaceous quartzite, marble, and calc-hornfels in inclusions or roof pendants in the granitic rocks have been examined very cursorily.

Near Point Reyes Station (DR-516), micaceous 
quartzite that contains garnet forms an inclusion in the granitic rock. The quartzite contains plagioclase and moderate-reddish-brown biotite and small amounts of muscovite sprinkled in a mat of mosaicked quartz.

A variety of metamorphic rocks are present along the shore of Tomales Bay at Tomales Bay State Park. These include dark schistose rocks rich in K-feldspar and reddish-brown biotite. Some layers are rich in quartz and are liberally peppered with sphene and metallic opaque minerals. Also found here, interlayered with the schists, are clinopyroxene-plagioclase calc-hornfels layers and associated marble. Other schists in this area are rich in cummingtonite and contain grayish-green garnet(?).

Another somewhat unusual rock, possibly metamorphic, is found along the road at DR-531. This medium-gray micaceous rock is medium to fine grained and has a hornfelsic texture. It has the same mineralogy as the enclosing granitic rock and similar reddish-brown biotite that is speckled with many pleochroic halos. Sillimanite and a metallic opaque mineral that is not attracted by a magnet, presumably ilmenite, are also found in the rock.

\section{DISTINGUISHING FEATURES}

The granitic rocks in the Point Reyes area are generally somewhat lighter colored than those to the north at Bodega Head and those to the south at Montara Mountain. Also, the abundance here of aplite and alaskite empirically seems to be associated with the presence of more-felsic granitic rocks. Also related to this general difference in rock type is the lesser amount of dark minerals, particularly the sparsity of hornblende. The lighter color of some hornblende may also be distinctive. The sparsity of metallic opaque minerals and sphene is particularly noteworthy in these granitic rocks. Cummingtonite and sillimanite in the metamorphic rocks may also prove to be distinctive.

\section{GRANODIORITE OF SOUTHEAST FARALLON ISLAND}

SETTING AND GENERAL DESGRIPTION

The Farallon Islands are a group of small barren islands about 30 miles west of San Francisco. The largest island, Southeast Farallon, is about 100 acres in area; the other islands are much smaller and almost inaccessible. Presumably all the islands are granitic, but how the rest compare with Southeast Farallon is not known. Access to Southeast Farallon was arranged by courtesy of the U.S. Coast Guard. Exposures are virtually continuous, but most are deeply weathered. In addition much of the outcrop is sprinkled to covered with guano, as the island provides nesting grounds for a large, and noisy, population of gulls, cormorants, and murres.
Locally along the shoreline, in some cobble beaches, the granodiorite is fresh and shows a mottled mixture of white feldspar, gray quartz, and irregular-shaped dark minerals. Scattered large biotite books up to 10 $\mathrm{mm}$ in size are characteristic. Equant masses of quartz are as much as $5 \mathrm{~mm}$ across. The weathered rock ranges from grayish orange to pale yellowish brown. The weathered surfaces are commonly etched and pock marked in such a way that they resemble coral masses.

Iron-stained chloritic or clay stringers along joints or shear zones make an irregular pattern, but some follow a northwesterly trend and are probably the zones of the weakness that have been the control for deep narrow sea slots along the shoreline.

The modes of the Farallon rocks are given in table 3 and plotted in figure 6. Considering the small size of the island, the number of samples reflects oversampling compared with other Coast Ranges areas. It is evident, however, that the rocks exposed on Southeast Farallon Island are rather homogenous granodiorite.

\section{MICROSCOPIC DESCRIPTION}

The granodiorite has a hypautomorphic-granular texture; plagioclase is generally well formed. Probably the most distinctive textural feature is the discreet large nearly equant quartz masses. These are particularly striking on an etched and stained surface.

Plagioclase is cleanly twinned and is generally sodic andesine. In part it is oscillatorily zoned, and some grains are composite. Much is thickly dusted with sericite. K-feldspar occurs solely as lacy interstitial

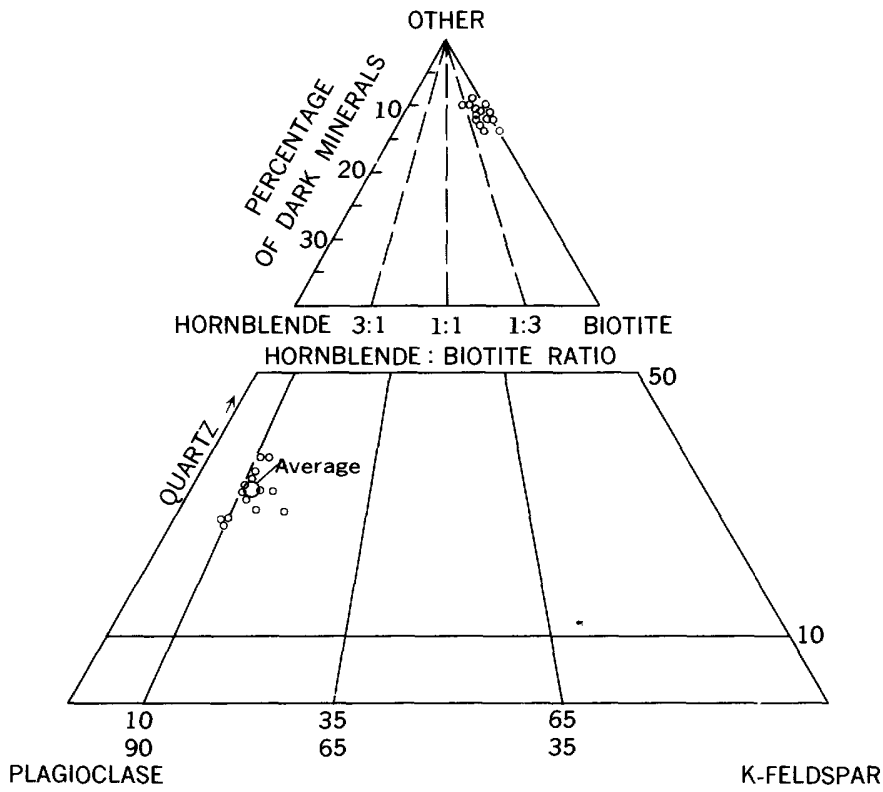

FIGURE 6.-Modal plot of granodiorite of Southeast Farallon Island. 
TABLE 3.-Modes of granodiorite of Southeast Farallon Island

\begin{tabular}{|c|c|c|c|c|c|c|}
\hline No. & $\begin{array}{l}\text { Plagio- } \\
\text { clase }\end{array}$ & $\begin{array}{l}\text { K-feld- } \\
\text { spar }\end{array}$ & Quartz & Biotite & $\begin{array}{c}\text { Horn- } \\
\text { blende }\end{array}$ & $\begin{array}{l}\text { Specific } \\
\text { gravity }\end{array}$ \\
\hline 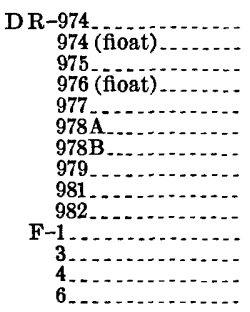 & $\begin{array}{l}54 \\
57 \\
53 \\
53 \\
51 \\
56 \\
55 \\
51 \\
51 \\
57 \\
52 \\
53 \\
54 \\
49\end{array}$ & $\begin{array}{r}6 \\
6 \\
9 \\
6 \\
10 \\
6 \\
7 \\
7 \\
6 \\
12 \\
6 \\
8 \\
6 \\
6 \\
7\end{array}$ & $\begin{array}{l}28 \\
25 \\
25 \\
31 \\
28 \\
24 \\
28 \\
33 \\
26 \\
23 \\
28 \\
32 \\
28 \\
33\end{array}$ & $\begin{array}{r}10 \\
10 \\
11 \\
10 \\
11 \\
12 \\
8 \\
7 \\
10 \\
14 \\
12 \\
8 \\
12 \\
10\end{array}$ & $\begin{array}{r}2 \\
2 \\
3 \\
1 \\
<1 \\
<1 \\
<1 \\
1\end{array}$ & $\begin{array}{l}2.62 \\
2.68 \\
2.63 \\
2.67 \\
2.53 \\
2.59 \\
2.59 \\
2.61 \\
2.67 \\
2.66 \\
2.60 \\
2.51 \\
2.61 \\
2.54\end{array}$ \\
\hline Average...... & 54 & 7 & 28 & 10 & 1 & 2.61 \\
\hline
\end{tabular}

grains that are sporadically distributed through the rock; the lack of poikiloblasts of $\mathrm{K}$-feldspar is atypical of this province. Quartz is highly fractured, but only weakly mosaicked; it reflects moderate strain.

Biotite as irregular crystals is the dominant dark mineral. Some grains are kinked and bent, and chloritization is variable but generally minor. In thin sections of the fresh rocks the green chloritic alteration shows strong ultrablue interference colors, whereas in thin sections of weathered specimens the chlorite is bleached and less distinctive. The biotite pleochroism is $\mathrm{X}=$ gray to moderate yellow and $\mathrm{Z}=$ moderate brown and moderate to dark yellowish brown. Hornblende is rather uncommon and occurs as irregular crystals. Some is almost completely replaced by pseudomorphs of brownish iron-stained chloritic(?) material. The pleochroism is $\mathrm{X}=$ moderate greenish yellow, $\mathrm{Y}=$ light to moderate olive, and $Z=$ light olive to moderate yellowish green.

Sphene, zircon, and apatite are found in all specimens, and allanite is found in most. Metallic opaque minerals are extremely rare; but do occur as small grains in hornblende. The sphene is generally irregular and interstitial; very few crystals are euhedral. The allanite is in part reddish brown, and some zoned crystals are rimmed with epidote. At least some epidote is probably primary. A patite generally occurs as abundant euhedral inclusions in biotite.

\section{DISTINGUISHING FEATURES}

In unweathered outcrop the granodiorite of Southeast Farallon Island generally resembles some of the granitic rocks on the mainland that extend from Bodega Head to Ben Lomond. The large scattered grains of dark minerals are the most obvious similarity.

The occurrence of $\mathrm{K}$-feldspar in the Farallon rocks is somewhat distinctive. $\mathrm{K}$-feldspar occurs only as lacy interstitial grains, whereas in most areas in the central Coast Ranges it tends to be at least locally poikiloblastic.
The virtual absence of metallic opaque minerals, except in trace amounts in hornblende, is also noteworthy. Coupled with this is the rarity of euhedral sphene, although irregular to skeletal grains are relatively common.

\section{GRANITIC ROCKS OF MONTARA MOUNTAIN}

\section{SETTING AND GENERAL DESGRIPTION}

The granitic mass making up Montara Mountain covers some 30 square miles along the Pacific coast south of San Francisco. In part the mass is bounded by faults; elsewhere Cenozoic rocks overlap the granitic outcrops. The rocks are generally deeply weathered and are poorly exposed in brushland and grassland. Fresh rock is uncommon in even rather deep roadcuts south of Devils Slide along Highway 1 and the nearby sea cliffs.

Fresh rocks are medium gray to medium dark gray and contain abundant hornblende and biotite. These rocks have a distinctive appearance, which is probably a combination of generally coarse-grained size and an abundance of dark minerals. The dark minerals tend to occur in rather irregular splotchy clusters. Commonly the rock is strongly foliated by the alinement of both dark minerals and dark dioritic inclusions. The foliation is steep, and the few observations made indicate that the trend is northwest roughly parallel to the trend of the Pilarcitos fault. This fault bounds the granitic mass on the east and is a possible ancestral branch of the San Andreas fault. In the Devils Slide area, the rock is cataclastically deformed along shear zones. Pegmatite and quartz veins in this area exhibit striking boudinaged and disrupted outcrop patterns, particularly in the well-exposed sea cliffs.

The modal data given in table 4 and plotted in figure 7 show that most of the Montara Mountain mass is quartz diorite containing very little K-feldspar. However, a few specimens have as much as 20 percent K-feldspar, although megascopically they appear identical with the other rocks. This variation seems to result from the sporadic occurrence of $\mathbf{K}$-feldspar rather than from multiple intrusions.

Dikes and small masses of aplite, alaskite, and simple pegmatite are present locally. On top of Montara. Mountain some fair-sized coarse-grained felsic bodies intrude the quartz diorite.

\section{MICROSCOPIC DESGRIPTION}

The granitic rocks of Montara Mountain are generally hypautomorphic- to xenomorphic-granular and are commonly somewhat cataclastic. Anastomosing shear zones in some thin sections are the most obvious signs 


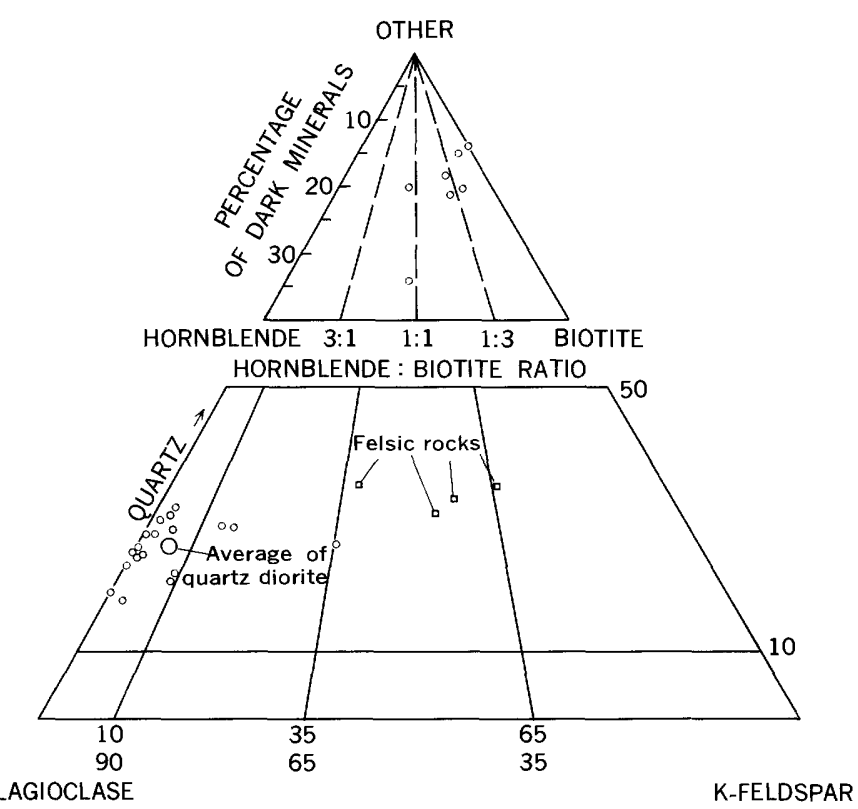

FraUre 7.-Modal plot of granitic rocks of Montara Mountain.

of shearing. More commonly, strain and incipient shearing are marked by undulatory extinction and mosaicking in quartz masses. Contacts between quartz grains are sutured, and granulation occurs where the shearing has been more pronounced. Some bent plagioclase crystals and biotite books were also noted.

TABLE 4.-Modes of quartz diorite and felsic rocks of Montara Mountain

\begin{tabular}{|c|c|c|c|c|c|c|}
\hline No. & $\begin{array}{l}\text { Plagio- } \\
\text { clase }\end{array}$ & $\begin{array}{c}\text { K-feld- } \\
\text { spar }\end{array}$ & Quartz & Biotite & $\begin{array}{l}\text { Horn- } \\
\text { blende }\end{array}$ & $\begin{array}{l}\text { Specific } \\
\text { gravity }\end{array}$ \\
\hline \multicolumn{7}{|c|}{ Quartz diorite } \\
\hline 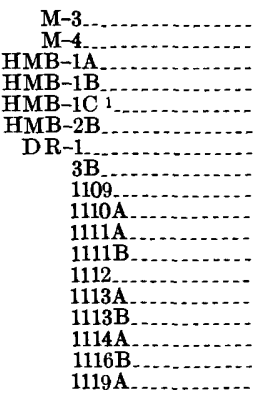 & $\begin{array}{l}57 \\
37 \\
59 \\
54 \\
57 \\
57 \\
53 \\
59 \\
54 \\
50 \\
48 \\
48 \\
57 \\
51 \\
54 \\
51 \\
49 \\
58\end{array}$ & \begin{tabular}{r}
21 \\
20 \\
2 \\
2 \\
1 \\
1 \\
1 \\
1 \\
5 \\
\hdashline 9 \\
9 \\
8 \\
\hdashline- \\
-1 \\
1 \\
5 \\
1
\end{tabular} & $\begin{array}{l}22 \\
20 \\
25 \\
26 \\
26 \\
22 \\
12 \\
20 \\
17 \\
15 \\
23 \\
23 \\
13 \\
17 \\
23 \\
17 \\
14 \\
19\end{array}$ & $\begin{array}{r}15 \\
14 \\
13 \\
13 \\
16 \\
16 \\
9\end{array}$ & $\begin{array}{lr} & 6 \\
23 & \\
& 5 \\
& 2 \\
& 4 \\
& 18 \\
& 11 \\
24 & \\
35 & \\
20 & \\
21 & \\
30 & \\
32 & \\
22 & \\
31 & \\
32 & \\
22 & \end{array}$ & $\begin{array}{ll}6 & 2.72 \\
& 2.69 \\
- & 2.70 \\
5 & 2.71 \\
2 & 2.70 \\
4 & 2.71 \\
8 & 2.81 \\
1 & 2.66 \\
& 2.73 \\
2.70(?) \\
2.67(?) \\
2.70 \\
2.68 \\
2.75 \\
2.70 \\
2.69 \\
2.69\end{array}$ \\
\hline A verage & 53 & 3 & 20 & 24 & & 2.71 \\
\hline \multicolumn{7}{|c|}{ Felsic rocks } \\
\hline $\begin{array}{r}\text { HMB-1D }{ }^{2} \\
\text { D R-1115A } \\
1115 \mathrm{~B} \\
1116 \\
\end{array}$ & $\begin{array}{l}22 \\
39 \\
30 \\
29\end{array}$ & $\begin{array}{l}42 \\
24 \\
34 \\
37\end{array}$ & $\begin{array}{l}34 \\
34 \\
29 \\
33\end{array}$ & $\begin{array}{l}3 \\
7 \\
1\end{array}$ & & $\begin{array}{l}2.58 \\
2.61 \\
2.54 \\
2.60\end{array}$ \\
\hline Average. . . & 30 & 34 & 33 & 3 & & 2.58 \\
\hline
\end{tabular}

1 Mode includes sphene, 1.
2 Mode includes chlorite, 2.
Plagioclase is common as well-formed crystals that are generally rather clean; in some specimens, however, alteration ranges from fine dusting with sericitic material to intense saussuritization in the cores of crystals. The index of refraction indicates the most calcic plagioclase to be sodic labradorite; crystals are zoned and grade to sodic andesine at the rims. Oscillatory zoning is present but is generally rather subtle.

Quartz is generally in space-filling irregular masses, as is $\mathrm{K}$-feldspar.

Both hornblende and biotite are abundant throughout this body in somewhat variable proportions, but biotite generally is more abundant. The habit of these minerals varies; some are well formed, and some are shredlike. Hornblende is skeletal in some specimens. Commonly the two minerals are intergrown or in clusters. The biotite is pleochroic from grayish yellow to various shades of brown. Hornblende is pleochroic from yellow green to darker shades of green, commonly with an olive hue. In some specimens biotite is fresh, but more commonly it is partly chloritized and in some specimens it is completely replaced by chlorite pseudomorphs. By contrast, hornblende is almost everywhere relatively unaltered, though some alteration to epidote is noted. The hornblende crystals are apparently relatively brittle, for they are generally much fractured and shattered, presumably from the cataclastic deformation of these rocks.

Apatite, zircon, and sphene are ubiquitous; allanite is locally present. Probably the most distinctive petrographic feature of these rocks is that metallic opaque minerals are generally absent or rare, which seems unusual in view of the high percentage (20 percent or more) of dark minerals.

\section{BASEMENT ROCKS OF THE BEN LOMOND AREA}

SETTING AND GENERAL DESGRIPTION

About 40 square miles of the Ben Lomond Mountain area, just north of Santa Cruz, is underlain by granitic and metamorphic rocks that form an irregular-shaped window through capping Cenozoic deposits. Small exposures east of this basement mass indicate a much greater extent of granitic basement at rather shallow depth beneath the Cenozoic cover.

Hornblende-biotite quartz diorite is the most abundant rock type, but an area of several square miles is underlain by metamorphic rocks-mica schist, quartzite, and marble-that are intruded by the quartz diorite. A small alaskitic plug and several satellitic alaskitic bodies also intrude the metamorphic sequence, but their age relative to the quartz diorite is uncertain. 
Small bodies of hornblende-cummingtonite gabbro are present in the quartz diorite.

These basement rocks have been described by Leo (1967). His report and map served as a valuable aid in locating good outcrops of the various rock types. Generally, the following discussion of the petrography is based on my limited observations and collections in the area, and where Leo's data are referred to, they will be specifically noted.

The quartz diorite of Ben Lomond is white to light gray and mottled with black hornblende and biotite on freshly broken surfaces. However, most outcrops appear dark because of weathering, lichen cover, and moss. Some specimens with abundant, large, and somewhat irregular-shaped books of biotite have a splotchy appearance reminiscent of some rocks from Montara Mountain. Variation in grain size within a single outcrop is also common. Dark fine-grained dioritic ovoid inclusions are present, and foliation is relatively common. Aplite, alaskite, and pegmatite dikes locally intrude the quartz diorite. Some of these dikes closely resernble the rocks of the small alaskite plug (Smith Grade pluton of Leo, 1967) that intrudes the metamorphic sequence.

The alaskite plug and related satellite bodies (Smith Grade pluton of Leo, 1967) are dominantly medium- to coarse-grained light-gray rocks that commonly weather light shades of yellow and orange. Coarser grained pegmatite and finer grained aplite are associated in these masses. Probably the most noteworthy feature of these rocks is the scattered pink garnet in many exposures. Black shiny biotite flakes are also sprinkled through the rock, and muscovite is found in trace amounts.

The isolated granitic outcrops east of the main basement mass generally seem to be petrographically different from both the quartz diorite and alaskite. These rocks are medium to coarse grained and rather felsic; their average modal composition is that of quartz monzonite. The close association of these rocks with $\mathrm{K}$-feldspar-poor rocks that in some outcrops look like the quartz diorite of Ben Lomond suggests, however, that they may be a variation of the quartz diorite. Leo (1967, p. 37) indeed suggested that these outcrops may be a late border phase of the quartz diorite of Ben Lomond. The present limited modal data (fig. 8), which plot in a distinctly different and separate field from the quartz diorite of Ben Lomond, suggest that these rocks may be a separate intrusive mass. Though the modes plot near the alaskite of Smith Grade, the rocks are quite different. The isolated quartz monzonite outcrops do not contain garnet, and they have significantly more biotite and some hornblende.
Modes of the quartz diorite of Ben Lomond and the alaskite of Smith Grade are given in table 5 and plotted in figure 8. They have about the same range as those reported by Leo (1967), also plotted in figure 8. These data emphasize that the great bulk of the quartz diorite of Ben Lomond has from 0 to 4 percent $\mathrm{K}$-feldspar but that locally, and seemingly sporadically, the K-feldspar content is significantly higher. The isolated masses east of Ben Lomond could well be more felsic variants on this same trend.

Less than 1 square mile is underlain by hornblende gabbro of variable grain size. These dark rocks look much like other hornblende gabbro that is widespread in the Transverse Ranges but which does not seem to be so common in the Coast Ranges. The relations of this rock with the quartz diorite are somewhat uncertain. Leo (1967) mapped a gradational contact between them, and at one outcrop area the gabbro looks as if it might be a variation of the quartz diorite. Unfortunately, poor exposures of this dark easily weathered rock preclude discussion of outcrop relations.

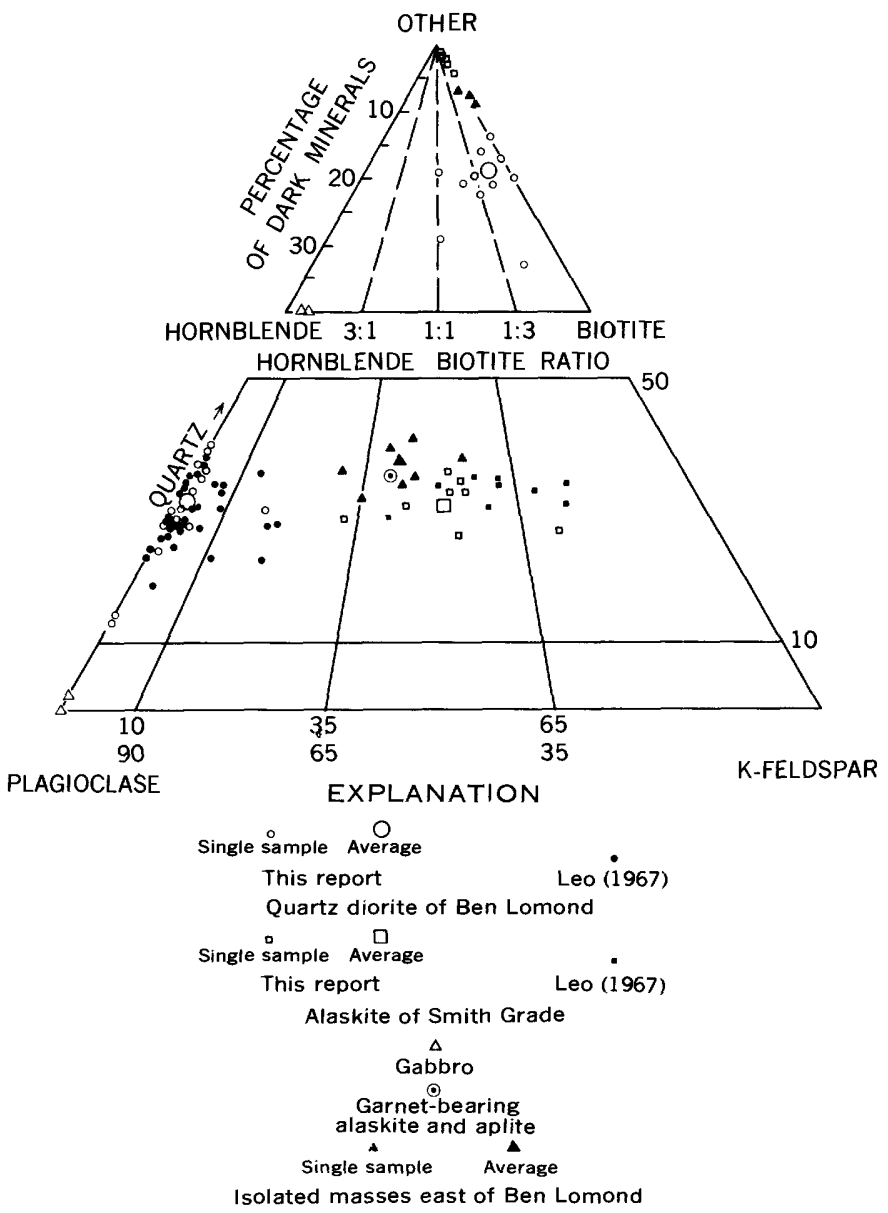

FIgure 8.-Modal plot of granitic rocks of the Ben Lomond area. 
TABLE 5.-Modes of granitic rocks of the Ben Lomond area $[\mathrm{G}=$ garnet, $\mathrm{Cum}=$ cummingtonite, $\mathrm{Clp}=$ clinopyroxene, $\mathrm{Tr} .=$ trace]

\begin{tabular}{|c|c|c|c|c|c|c|c|}
\hline No. & $\begin{array}{l}\text { Plagio- } \\
\text { clase }\end{array}$ & $\begin{array}{c}\text { K- } \\
\text { feldspar }\end{array}$ & Quartz & Biotite & e $\begin{array}{c}\text { Horn- } \\
\text { blende }\end{array}$ & Other & $\begin{array}{l}\text { Specific } \\
\text { gravity }\end{array}$ \\
\hline \multicolumn{8}{|c|}{ Quartz diorite of Ben Lomond } \\
\hline Leo-126 & $\begin{array}{l}50 \\
53\end{array}$ & 1 & 28 & $\begin{array}{l}14 \\
15\end{array}$ & $\begin{array}{r}7 \\
14\end{array}$ & & $\begin{array}{l}2.77 \\
2.77\end{array}$ \\
\hline & $\begin{array}{l}69 \\
69\end{array}$ & $\begin{array}{l}1 \\
3 \\
1\end{array}$ & 24 & 14 & $\ldots$ & & 2. 67 \\
\hline DR-494 & $\begin{array}{l}53 \\
50\end{array}$ & $\begin{array}{l}1 \\
\text { Tr. }\end{array}$ & $\begin{array}{l}27 \\
34\end{array}$ & $\begin{array}{l}10 \\
14\end{array}$ & $\begin{array}{l}9 \\
2\end{array}$ & & $\begin{array}{l}2.75 \\
2.72\end{array}$ \\
\hline 4978 & 56 & .... & 24 & 20 & & $\ldots$ & 2. 69 \\
\hline $\begin{array}{l}497 \mathrm{C}- \\
501\end{array}$ & $\begin{array}{l}58 \\
56\end{array}$ & $\operatorname{Tr}^{1}$ & ${ }_{22}^{24}$ & $\begin{array}{l}17 \\
17\end{array}$ & 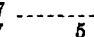 & & $\begin{array}{l}2.70 \\
2.74\end{array}$ \\
\hline $503 \ldots$ & 50 & $i$ & 29 & 15 & & & 2.71 \\
\hline & $\begin{array}{l}50 \\
67\end{array}$ & Tr. & $\begin{array}{l}29 \\
10\end{array}$ & $\begin{array}{l}18 \\
14\end{array}$ & & & $\begin{array}{l}2.73 \\
2.75\end{array}$ \\
\hline & 50 & 10 & 26 & & 14 & & 2.68 \\
\hline & 54 & Tr. & & 19 & $\begin{array}{r}5 \\
14\end{array}$ & & 2.75 \\
\hline $\begin{array}{l}11 \\
49\end{array}$ & 41 & $\cdots$ & 26 & 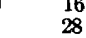 & ${ }_{5}^{14}$ & 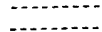 & $\begin{array}{l}2.73 \\
2.73\end{array}$ \\
\hline$\cdots$ & $\begin{array}{lllll}41 \\
41\end{array}$ & 17 & 33 & & & 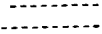 & 2.62 \\
\hline 110 & 35 & 26 & 32 & 6 & 1 & -. & 2.64 \\
\hline 110 & ${ }_{32}^{27}$ & $\begin{array}{l}32 \\
26\end{array}$ & $\begin{array}{l}36 \\
32\end{array}$ & & ${ }_{10}^{5}$ & (n......... & $\begin{array}{l}2.64 \\
2.63\end{array}$ \\
\hline & 41 & 22 & 30 & & 7 & 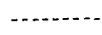 & 2. 66 \\
\hline & & & & & & & 2.65 \\
\hline $1106 \mathrm{~A}$ & 34 & 2 & 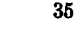 & & 9 & & 2. \\
\hline $\begin{array}{c}\text { Average (Leo-126- } \\
\text { D R-1106B) }\end{array}$ & 55 & 1 & 23 & 15.5 & 5.5 & $\cdots$ & 2.73 \\
\hline A98D-1106A) & 34 & 24 & 34 & & 18 & 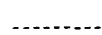 & 2.64 \\
\hline
\end{tabular}

\begin{tabular}{|c|c|c|c|c|c|c|}
\hline \multicolumn{7}{|c|}{ Alaskite of Smith Grade } \\
\hline $\begin{array}{r}\text { Le0-66A } \\
263 \\
310 \\
\text { DR-496A } \\
496 \mathrm{~B} \\
1107 \mathrm{~A} \\
1107 \mathrm{~B} \\
1108 \\
1103 \text { (dike) }\end{array}$ & $\begin{array}{l}21 \\
32 \\
30 \\
38 \\
47 \\
29 \\
33 \\
29 \\
38\end{array}$ & $\begin{array}{l}52 \\
34 \\
32 \\
30 \\
23 \\
35 \\
37 \\
34 \\
26\end{array}$ & $\begin{array}{l}27 \\
33 \\
34 \\
31 \\
28 \\
32 \\
26 \\
33 \\
35\end{array}$ & 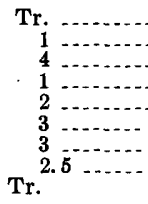 & \begin{tabular}{l} 
\\
\hdashline (G) 1 \\
(G) 1.5 \\
(G) 1
\end{tabular} & $\begin{array}{l}2.60 \\
2.61 \\
2.63 \\
2.63 \\
2.61 \\
2.63 \\
2.63 \\
2.63 \\
2.62\end{array}$ \\
\hline Average..... & 33 & 34 & 31 & 2 & $<1$ & 2.62 \\
\hline
\end{tabular}

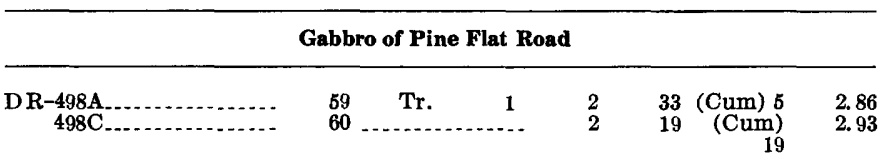

\begin{tabular}{llllllllll}
\hline \multicolumn{8}{c}{ Granodiorite orthogneiss of Laguna Creek of Leo (1967) } \\
\hline DR-499 & $\ldots \ldots \ldots \ldots \ldots \ldots$. & 47 & 6 & 30 & 13 & 4 & $\left(\begin{array}{c}\text { (Clp) } \\
<1\end{array}\right.$ & 2.70 \\
\hline
\end{tabular}

1 Biotite dominant.

The metamorphic rocks mentioned earlier are dominantly dark-colored mica schist and micaceous quartzite with lesser amounts of marble. I have examined them only briefly. In general they look like other schist and quartzite, with little to distinguish them. Some specimens contain garnet and cordierite, and Leo (1967, p. 40) noted sillimanite. Of possible note is a unit that Leo $(1967$, p. 32$)$ called granodiorite orthogneiss. He interpreted this rock to be a synkinematic intrusion into the schist and quartzite sequence; it may, however, be part of the schist and quartzite sequence. Both in hand specimen and thin section it is a rather distinctive foliated rock that is a combination of white and black minerals where the rock is fresh. It is not a gneiss in the sense of having segregated dark and light bands, but it is strongly foliated owing to the alinement lenticular masses of dark minerals in a light-colored, shapeoriented matrix.

\section{MICROSCOPIG DESCRIPTION \\ Quartz Diorite of Ben Lomond}

The quartz diorite of Ben Lomond is generally hypautomorphic-granular, but displays a variety of textures, ranging from a "clean" texture with neareuhedral hornblende and subhedral plagioclase to a "messy" texture with irregular dark minerals and few well-formed crystals. Some foliation is shown in thin section by orientation of dark minerals and quartz.

The plagioclase is commonly subhedral and cleanly and sharply twinned. Oscillatory zoning is clearly evident, and the range of zoning is within the field of andesine. Most of the plagioclase seems to be sodic andesine. Alteration is surprisingly uncommon; some chloritic and clay-altered cores of crystals are present, but there is little sericitization. Small hornblende crystals are enclosed within some plagioclase grains.

K-feldspar, generally rare, occurs as interstitial stringers. It is absent from many specimens.

Quartz is an abundant constituent, as common as in the alaskitic rocks. It forms masses comparable in size to the plagioclase crystals. Most quartz has undulatory extinction, and in some specimens it is mosaicked and has sutured intergranular contacts. Some quartz is highly mosaicked and almost granulated. The amount of strain shown by the quartz in this mass is rather variable. In some specimens the quartz appears to have replaced plagioclase along scalloped contacts; some plagioclase is markedly embayed by quartz.

Biotite is the most abundant dark mineral, making up as much as 20 percent of some rocks. It ranges from rather well-formed books to irregular, shredlike grains and aggregates, the largest of which are $10 \mathrm{~mm}$ across. Biotite is pleochroic from $\mathrm{X}=$ grayish yellow to grayish orange to $Z=$ moderate reddish brown and less commonly moderate to dark yellowish brown. Chloritic alteration is uncommon, particularly north of the Bald Mountain fault.

Hornblende is nearly as abundant as biotite in some specimens, but it is generally subordinate, and in some specimens it is absent. It is in part well formed, but more commonly is in irregular crystals. Rocks south of the Bald Mountain fault generally contain less hornblende, and, where present, the hornblende forms shredded pale-green aggregates; in contrast, biotite books are fresh and well formed in the same specimens. In one of these specimens, matted aggregates of biotite are suggestive of pseudomorphs after hornblende. The pleochroism of the hormblende is $\mathrm{X}=$ moderate yellowish green, $Y=$ light olive to light olive brown, and $Z=$ 
moderate yellowish green and less commonly dusky yellow and light olive brown. The shredlike crystals range from almost colorless to pale green. In general the hornblende of this mass is lighter colored than other hornblende in the region. It also seems unusual for a quartz diorite to have upwards of 20 percent biotite and no hornblende. Leo $(1967$, p. 36$)$ noted color differences in hornblende on opposite sides of the Bald Mountain fault, which he says may be related to the ferrous-ferric iron ratio. There may well be something unusual about the dark mineral relations in this mass.

Metallic opaque minerals and sphene are extremely rare to absent in these rocks. The former, where present, occur as small crystals in hornblende and biotite. Most sphene is in trains of tiny grainlets along cleavage traces in somewhat altered biotite. Some sphene occurs as small discrete grains, but these are irregular; no wedgeshaped euhedral crystals were found. Apatite is the only accessory mineral that seems to be present in all the specimens. Zircon is fairly widespread, and allanite is rare.

\section{Alaskite of Smith Grade}

The alaskite of Smith Grade is generally xenomorphic-granular with a rather "messy," irregular fabric. It grades to pegmatitic coarser phases and to aplitic finer grained rocks. These rocks resemble late felsic differentiates-the type of aplite-alaskite-pegmatite sequence present in all the Coast and Transverse Ranges granitic areas.

Plagioclase occurs as irregular, ragged crystals and is in the albite-oligoclase range. Commonly it is liberally dusted with sericitic alteration material, but adjacent to $\mathbf{K}$-feldspar a clean rim of possibly exsolved plagioclase (albite?) is generally present. The K-feldspar is also quite irregular in habit; it encloses plagioclase and quartz and is strongly grid twinned.

Quartz occurs as masses as much as $10 \mathrm{~mm}$ across which show very little evidence of strain. Some undulatory extinction is found in most sections, and so is some incipient mosaicking. On the whole, quartz in the alaskite shows less strain than in the quartz diorite of Ben Lomond.

Biotite, where present, is in scattered dark flakes; some is extensively altered to chlorite and iron oxides. The least altered flakes have the following pleochroism: $\mathrm{X}=$ grayish yellow to grayish orange and $\mathrm{Z}=$ moderate reddish brown and less commonly moderate yellowish brown, generally similar to the biotite of the quartz diorite.

Pink garnet, in part euhedral, is sprinkled through this rock and makes it very distinctive. Minor apatite and zircon, and rare metallic opaque minerals and blue tourmaline are also found.
Large masses, as much as several hundred feet across, of fine-grained dark-colored sugary material with a dioritic composition are abundant in the alaskite along the Empire Grade. These masses appear to be inclusions, as they are crisscrossed with dikes of garnet-bearing rock that resembles the Smith Grade mass. Dikes of this sugary material also cut the Smith Grade rocks. The origin of these masses is not known, but they are similar in texture and composition to hornfelsed schist near some granitic contacts in the Ben Lomond area. Most probably, the sugary "dioritic" masses are hornfelsed schist inclusions that were locally mobile enough to be squirted around as dikes.

Leo (1961) made the first detailed study of the alaskite. He considered it to be the youngest granitic rock in the area (younger than the quartz diorite). Compton (1966), who subsequently examined the Smith Grade rocks, reported biotite lineations that were generally parallel to fold axes and mineral lineations in the metamorphic rocks. This led Leo $(1967$, p. 33) to reconsider his conclusions and to suggest that intrusion of the Smith Grade rocks was synkinematic, older than the quartz diorite, and of about the same age as a strongly deformed granodiorite orthogneiss in the schist and quartzite sequence.

From my limited field and thin section study of the Smith Grade rocks, I am extremely wary of considering this an old, deformed granitic body; the alaskitic rock has much virtually unstrained quartz, appears undeformed, and physically resembles young dike rocks in the Ben Lomond area.

If the alaskite is young and is a late differentiate of the granitic suite, one would expect intrusions into the quartz diorite. Garnet-bearing alaskite-aplite that resembles the alaskite of Smith Grade intrudes quartz diorite near DR-497 and the isolated granitic masses east of Ben Lomond.

To me, the evidence is equivocal, and the age of the alaskite relative to the quartz diorite is at present uncertain. However, at Leo's locality 66, where garnetbearing alaskite intrudes schist and quartzite, the intrusion certainly postdates metamorphism.

\section{Other Rock Types}

The isolated masses east of Ben Lomond have a coarse anhedral texture. The plagioclase is probably mostly oligoclase. Brown biotite and lesser amounts of green hornblende generally occur as irregular crystals and aggregates and have the same pleochroism as in the quartz diorite of Ben Lomond. Both quartz and K-feldspar occur as irregular crystals that are very coarse locally. The usual granitic accessory minerals are present, but metallic opaque minerals are rare. 
The dark gabbroic rocks as already noted, have little to distinguish them in hand specimen. In thin section they have a xenomorphic texture that looks almost hornfelsic or aplitic. Nearly colorless, optically positive amphibole, which is probably cummingtonite, is common in these rocks. It occurs as distinct crystals and also as cores of light-brown optically negative hornblende that has somewhat greenish tints in part. The hornblende (?) is lighter colored than "typical" hornblende of gabbros. A small amount of red-brown biotite is present, but there is no clinopyroxene. Leo (1967, p. 34) did note some hypersthene locally. Metallic opaque minerals are common, particularly in the amphibole; much is probably ilmenite.

The granodiorite orthogneiss of Leo (1967, p. 32) has a strongly alined fabric with shape-oriented minerals. It has well-twinned sodic andesine, grid-twinned $\mathrm{K}$ feldspar, and sutured and mosaicked quartz. The dominant dark mineral is biotite, which is pleochroic from grayish orange to moderate reddish brown. Hormblende, less abundant, is pleochroic from moderate greenish yellow to light olive. Some of the hornblende occurs as lacy crystals that include partly replaced clinopyroxene. The presence of well-rounded grains of zircon that look detrital suggests that this rock may be a highly metamorphosed sedimentary unit.

\section{DISTINGUISHING FEATURES}

In general compositional and textural range, the quartz diorite of Ben Lomond strongly resembles rocks of the Montara Mountain mass. The extreme rarity of metallic opaque minerals and sphene is certainly distinctive in rocks that have generally $15-20$ percent of dark minerals. Probably the most distinctive feature of the quartz diorite is that the hornblende is somewhat lighter colored than that in quartz diorite elsewhere in the region; also, a number of specimens lack hornblende. The somewhat sporadic occurrence of hormblende, its lighter color, and the virtual absence of metallic opaque minerals seem to point to a possibly distinctive rock.

The alaskite of Smith Grade is a rather prosaic alaskite-aplite-pegmatite mass, but the liberal sprinkling of pink garnet crystals is noteworthy because of their rarity in Coast Ranges felsic granitic rocks.

The gabbroic rocks are distinctive in containing cummingtonite, somewhat pale hornblende, and no clinopyroxene. The outcrops and hand specimens do not betray this rather distinctive mineralogy, however.

The granodiorite orthogneiss of Leo $(1967$, p. 32$)$ is an unusual rock type for this region. It has the appearance of a high-grade metamorphic rock, seemingly out of place in the general metamorphic terrane of Ben Lomond.

\section{QUARTZ DIORITE OF GORDELL BANK}

During investigation of the geology of the continental slope off central Califormia, dredge hauls brought up granitic rocks from at least five localities on Cordell Bank (Hanna, 1952). These areas of presumably submarine granitic outcrop are about 20 miles west of the Point Reyes granitic outcrops and about 30 miles northwest of the Southeast Farallon Island granitic outcrops. These outcrops on the edge of the continental shelf are the westernmost "exposures" of Salinian block granitic rocks.

Chesterman (1952, p. 360-361) briefly described the petrography of these rocks. He noted that the specimens are coarse grained, equigranular, massive to slightly gneissoid, and composed dominantly of plagioclase $\left(\mathrm{An}_{25-35}\right)$ and quartz. They contain small amounts of $\mathrm{K}$-feldspar and varying amounts of dark-brown biotite and dark-green hornblende; biotite is most common. Sphene, zircon, apatite, and magnetite occur sporadically as inclusions in other minerals.

\section{SOUTHERN COAST RANGES}

\section{GRANITIC ROGKS OF THE GABILAN RANGE}

The Gabilan Range is a dominantly granitic massif more than 350 square miles in area, rising more than 3,000 feet above the Salinas Valley. The granitic mass contains abundant roof pendants and inclusions of dominantly carbonate rocks, and less commonly schist and calc-hornfels. The included metamorphic rocks seem more abundant in the northern part of the range. In addition to the generally sharply defined metamorphic pendants and inclusions, there are minor less welldefined gneissic zones.

The granitic basement rocks are cut off along the east side of the range by the San Andreas fault and along the north side by the Vergeles fault (pl. 2). The south and southwest sides of this granitic block are overlapped by valley fill and other late Cenozoic sedimentary deposits.

The limited sample coverage of the Gabilan Range shows that two granitic types dominate the range. Much of the north end of the range is underlain by a large mass of coarse-grained felsic rock that will be referred to as the quartz monzonite of Fremont Peak. The central and southern part of the range is dominated by a much larger mass that will be tentatively called the granodiorite of the Gloria-Bickmore Road. The preliminary data in this report establish that the Gabilan plutonic rocks are a composite batholithic mass. Fur- 
ther sampling and mapping are now underway to delineate and further refine the geology; the result of that work will be presented later and will undoubtedly change the present rather simple picture.

Several smaller masses have been delineated that include (1) the quartz diorite of Vergeles at the extreme north end of the range, (2) the granodiorite of Grass and Thompson Creeks, (3) the quartz monzonite of the Gloria-Bickmore Road, and (4) the quartz monzonite of the Metz railroad tunnel.

Each of the Gabilan Range rock types will be described separately, and their relations and significance will be summarized. It is important to remember that the Gabilan Range is by far the largest granitic outcrop area in the Coast Ranges.

\section{QUARTZ MONZONITE OF FREMONT PEAK}

\section{Setting and General Description}

A large part of the northern Gabilan Range may be underlain by the quartz monzonite of Fremont Peak, a coarse-grained felsic rock. Exposures are generally poor and roadcuts are deeply weathered, but some fairly fresh outcrops are found locally. The rocks weather to light shades of yellow and orange. Sparse amounts of biotite are sprinkled through the rock. In places the $\mathrm{K}$-feldspar is slightly pinkish and in spongy poikiloblasts as large as $15 \mathrm{~mm}$. In some outcrops the rock ranges from coarse to fine grained. The finer grained rocks have an almost salt-and-pepper texture. In part, these rocks of variable grain size are somewhat gneissic.

The average of the modal analyses (table 6, fig. 9) of 18 specimens shows that the two feldspars and quartz are present in nearly equal amounts. This modal composition and empirically the general appearance suggest rocks associated with the "low melting trough"possibly one of the younger rocks in the Gabilan granitic suite.

\section{Microscopic Description}

These rocks generally have a xenomorphic texture; some are in part aplitic and are characterized by sprinklings of quartz droplets. Locally there is strong shape orientation of quartz and feldspar in the felsic rocks. Along the east side of the Gabilan Range, along Thompson Creek, the rocks appear to be more gneissic, and also some float in the creek is foliated.

The zoned, well-twinned plagioclase ranges from oligoclase to sodic andesine, and some is as sodic as albite. K-feldspar occurs as abundant, irregular crystals that corrode and engulf other constitutents. Grid-twinning is fairly common, and patchy perthite is also present. Quartz is equal in abundance to both plagioclase and $\mathrm{K}$-feldspar. It ranges from small interstitial grains to masses several millimeters in size that are generally mosaicked. Most of the quartz has undulatory extinction, and some intragranular contacts in the quartz masses are sutured. Most of the quartz reflects some strain, but locally coarse masses show almost no sign of strain. Some quartz is sprinkled through the rock in rounded crystals in addition to its normal habit.

TABLE 6.-Modes of granitic rocks of the Gabilan Range

[E=epidote, $\quad \mathrm{S}=$ sphene, $\quad \mathrm{Me}=$ metallic opaque minerals, $\quad \mathrm{Ch}=$ chlorite, $\mathbf{M u}=$ muscovite, $\mathbf{A p}=$ apatite, $\mathrm{Tr} .=$ trace]

\begin{tabular}{|c|c|c|c|c|c|c|}
\hline No. & $\begin{array}{c}\text { Plagio- } \\
\text { clase }\end{array}$ & $\begin{array}{c}\text { K-feld- } \\
\text { spar }\end{array}$ & Lartz Biotite & $\begin{array}{l}\text { Horn- } \\
\text { blende }\end{array}$ & Other & $\begin{array}{l}\text { Specific } \\
\text { gravity }\end{array}$ \\
\hline \multicolumn{7}{|c|}{ Quartz monzonite of Fremont Peak } \\
\hline 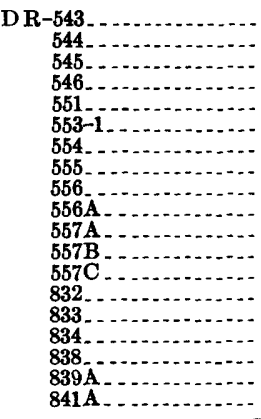 & $\begin{array}{l}27 \\
28 \\
33 \\
24 \\
31 \\
24 \\
29 \\
29 \\
31 \\
39 \\
37 \\
31 \\
38 \\
30 \\
29 \\
35 \\
34 \\
30 \\
29\end{array}$ & $\begin{array}{l}\mathbf{3 3} \\
\mathbf{3 5} \\
\mathbf{3 5} \\
\mathbf{3 5} \\
\mathbf{3 1} \\
\mathbf{4 0} \\
36 \\
\mathbf{3 8} \\
\mathbf{3 3} \\
\mathbf{2 3} \\
\mathbf{2 7} \\
\mathbf{2 8} \\
\mathbf{3 1} \\
\mathbf{3 1} \\
\mathbf{3 4} \\
27 \\
\mathbf{3 3} \\
\mathbf{3 5} \\
\mathbf{3 4}\end{array}$ & $\begin{array}{l}\mathbf{3 6} \\
33 \\
28 \\
39 \\
32 \\
31 \\
33 \\
27 \\
33 \\
33 \\
28 \\
36 \\
27 \\
35 \\
32 \\
35 \\
30 \\
\mathbf{3 2} \\
\mathbf{3 3}\end{array}$ & \begin{tabular}{l}
0 \\
\hdashline \\
\hdashline \\
0
\end{tabular} & & $\begin{array}{l}2.61 \\
2.60 \\
2.62 \\
2.61 \\
2.62 \\
2.62 \\
2.58 \\
2.63 \\
2.62 \\
2.62 \\
2.63 \\
2.64 \\
2.62 \\
2.63 \\
2.62 \\
2.64 \\
2.61 \\
2.62\end{array}$ \\
\hline Avera & 31 & 33 & 32 & & & 2.6 \\
\hline
\end{tabular}

Granodiorite of Gloria-Bickmore Road

\begin{tabular}{|c|c|c|c|c|c|c|c|}
\hline $\begin{array}{r}\text { DR-563A } \\
563 \mathrm{~B} \\
564\end{array}$ & $\begin{array}{l}49 \\
52 \\
51\end{array}$ & $\begin{array}{r}15 \\
13 \\
6\end{array}$ & $\begin{array}{l}24 \\
23 \\
29\end{array}$ & $\begin{array}{r}12 \\
11 \\
9\end{array}$ & & $\begin{array}{cl}1 & (\mathrm{E})<1 \\
1 & \begin{array}{l}(\mathrm{S}) 1 \\
(\mathrm{~S}) 1 \\
(\mathrm{Me}) 1\end{array} \\
& (\mathrm{E}) 1\end{array}$ & $\begin{array}{l}2.69 \\
2.68 \\
2.72\end{array}$ \\
\hline $\begin{array}{l}565 \mathrm{~A}- \\
565 \mathrm{~B}\end{array}$ & & 5 & 22 & 21 & & $1 \ldots$ & $\begin{array}{l}2.72 \\
2.67\end{array}$ \\
\hline 566 & & 11 & 0 & $\begin{array}{l}15 \\
15\end{array}$ & & $8(\mathrm{E})^{2}$ & 2.0 \\
\hline & 53 & $\begin{array}{l}10 \\
20\end{array}$ & $\frac{18}{20}$ & ${ }_{13}^{11}$ & & & 2.7 \\
\hline & 54 & 2 & 19 & 12 & & 10 & \\
\hline & 52 & 14 & 23 & 13 & & $7^{-(C h) 11}$ & \\
\hline & 39 & 24 & so & 10 & & (Ch) 7 & 2. \\
\hline & $\begin{array}{ll}44 \\
42\end{array}$ & 19 & $\begin{array}{l}32 \\
31\end{array}$ & 5 & & 2 (S)i & 2.6 \\
\hline $\begin{array}{l}574 \mathrm{~A}_{-} \\
575 \mathrm{~B}\end{array}$ & 45 & $\begin{array}{l}15 \\
20\end{array}$ & $\frac{3}{2}$ & 9 & & 1 & \\
\hline $577-$ & 40 & 19 & 30 & 10 & & (E) 1 & . \\
\hline $580 \mathrm{~A}^{-}$ & 49 & $\begin{array}{l}21 \\
16\end{array}$ & 18 & 17 & & & $\ddot{a}$ \\
\hline $\begin{array}{l}\text { 581A. } \\
\text { 582.. }\end{array}$ & $\begin{array}{l}51 \\
42\end{array}$ & 18 & $\begin{array}{l}16 \\
34\end{array}$ & $\begin{array}{r}20 \\
5\end{array}$ & 1 & 3 & \\
\hline 584- & 48 & 8 & 19 & 12 & & 2 (S) 1 & 7 \\
\hline & 59 & $<1$ & 24 & 13 & & 1 (S)1, (E)2 & \\
\hline 84 & $\begin{array}{l}44 \\
54\end{array}$ & $\begin{array}{r}3 \\
<1\end{array}$ & $\begin{array}{l}41 \\
32\end{array}$ & & 2 & ............. & 2. \\
\hline $\begin{array}{l}84 \\
84\end{array}$ & 39 & & 40 & 21 & & - & 71 \\
\hline & 44 & $\begin{array}{r}9 \\
18\end{array}$ & $\begin{array}{l}28 \\
24\end{array}$ & 11 & & $2(\mathrm{~S}, \mathrm{Me}) 1$ & 2.7 \\
\hline 851 & 40 & 21 & $\mathbf{3 3}$ & 6 & & & 2.6 \\
\hline G- & $48 \quad-$ & 16 & 23 & 11 & & $1(\mathrm{~S}, \mathrm{Me}) 1$ & \\
\hline$\cdots$ & 48 & & 31 & $\begin{array}{l}5 \\
6\end{array}$ & & & 2.66 \\
\hline $\begin{array}{l}104 \\
104\end{array}$ & $\begin{array}{l}48 \\
38\end{array}$ & $\begin{array}{l}22 \\
24\end{array}$ & $\begin{array}{l}32 \\
33\end{array}$ & $\begin{array}{l}6 \\
5\end{array}$ & & ..... & .64 \\
\hline & 46 & 17 & 30 & 6 & & & \\
\hline & 51 & 9 & 3 & & 8 & ..... & \\
\hline & 4 & 10 & & & & $7^{-1}$ & 78 \\
\hline . & & 2 & 16 & 16 & & 3 (S)1, (E)4 & 2.73 \\
\hline -.. & 47 & 13 & 26 & 11 & & & \\
\hline
\end{tabular}



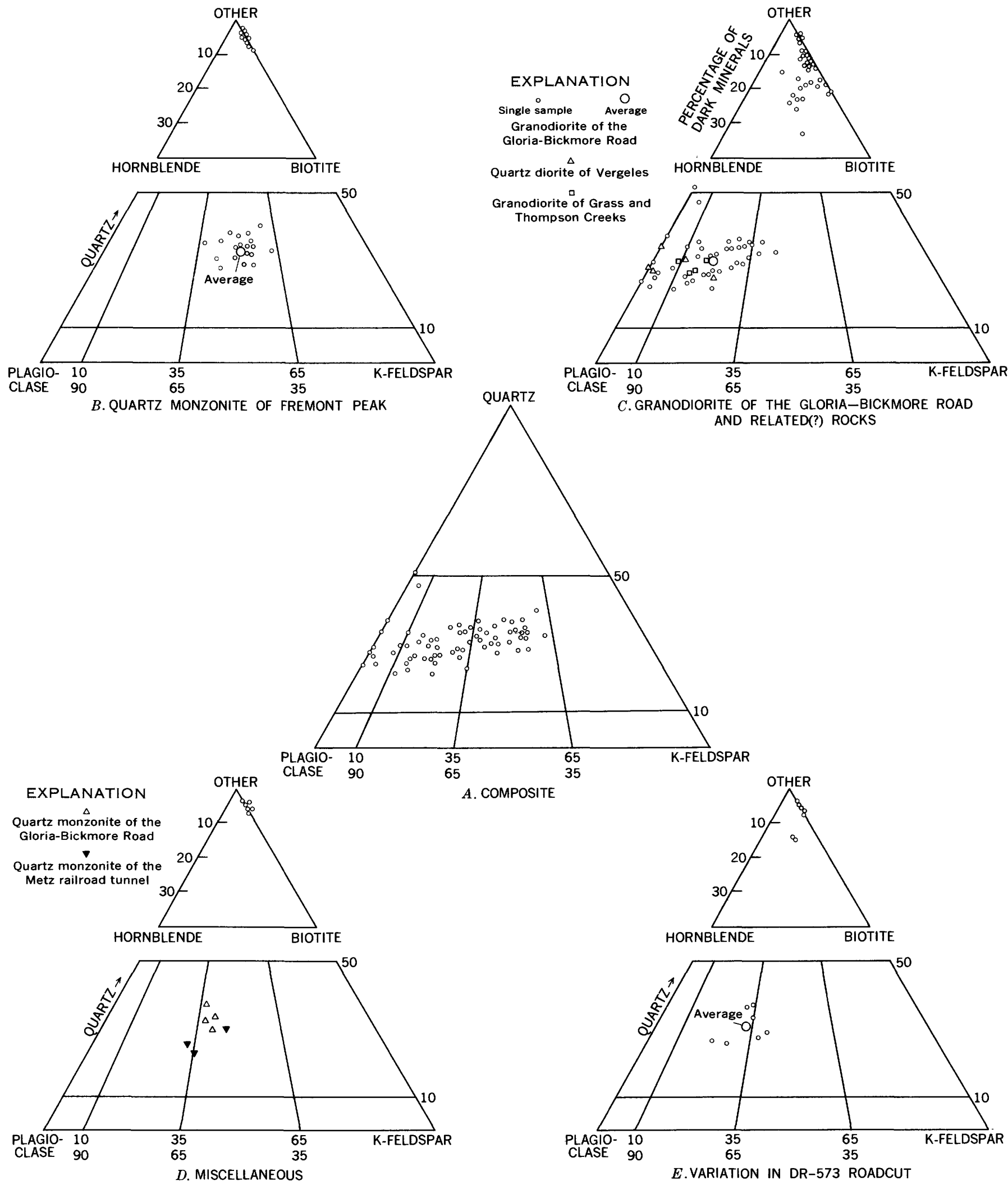
TABLE 6.-Modes of granitic rocks of the Gabilan Range-Continued

\begin{tabular}{|c|c|c|c|c|c|c|c|}
\hline No. & $\begin{array}{l}\text { Plagio- } \\
\text { clase }\end{array}$ & $\begin{array}{l}\text { K-feld- } \\
\text { spar }\end{array}$ & Quartz & Biotite & $\begin{array}{l}\text { Horn- } \\
\text { blende }\end{array}$ & Other & $\begin{array}{l}\text { Specific } \\
\text { gravity }\end{array}$ \\
\hline \multicolumn{8}{|c|}{ Variation in granodiorite of Gloria-Bickmore Road in DR-573 roadcut } \\
\hline 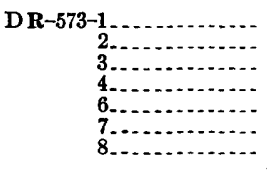 & $\begin{array}{l}39 \\
42 \\
48 \\
40 \\
46 \\
40 \\
41\end{array}$ & $\begin{array}{l}27 \\
26 \\
14 \\
19 \\
17 \\
20 \\
21\end{array}$ & $\begin{array}{l}27 \\
26 \\
23 \\
34 \\
22 \\
36 \\
30 \\
\end{array}$ & & $\begin{array}{r}7 \\
3 \\
3 \\
\cdots \\
\cdots\end{array}$ & $\begin{array}{l}(\mathrm{S}) 1 \\
(\mathrm{Me}) 1 \\
(\mathrm{~S}) 1 \\
(\mathrm{M} e, \mathrm{~S}) 1 \\
\end{array}$ & $\begin{array}{l}2.63 \\
2.66 \\
2.74 \\
2.67 \\
2.72 \\
2.66 \\
2.66 \\
\end{array}$ \\
\hline Average........... & 42 & 21 & 28 & 7 & 2 & & 2.68 \\
\hline \multicolumn{8}{|c|}{ Quartz diorite of Vergeles } \\
\hline $\begin{array}{r}\text { DR-539A } \\
540, \ldots \\
541 \mathrm{~A} \\
541 \mathrm{~B} \\
548 \\
\end{array}$ & $\begin{array}{l}53 \\
56 \\
49 \\
57 \\
54\end{array}$ & $\begin{array}{r}1 \\
7 \\
15\end{array}$ & $\begin{array}{l}20 \\
27 \\
21 \\
29 \\
21\end{array}$ & $\begin{array}{r}15 \\
10 \\
6 \\
12 \\
14\end{array}$ & \begin{tabular}{c}
11 \\
\hdashline 9 \\
1 \\
9
\end{tabular} & $\begin{array}{l}(\mathrm{S}, \mathrm{Ap}) 1 \\
(\mathrm{~S}) 1,(\mathrm{E}) 1\end{array}$ & $\begin{array}{l}2.75 \\
2.67 \\
2.74 \\
2.72 \\
2.73\end{array}$ \\
\hline A verage........... & 54 & 5 & 24 & 11 & 6 & & 2.72 \\
\hline
\end{tabular}

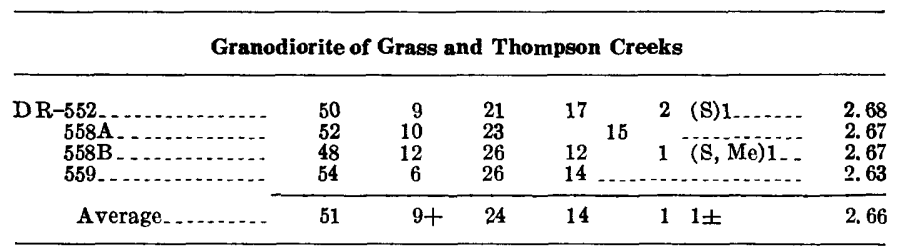

\begin{tabular}{|c|c|c|c|c|c|c|}
\hline \multicolumn{7}{|c|}{ Quartz monzonite of the Gloria-Bickmore Road } \\
\hline $\begin{array}{r}\text { DR-561B } \\
562 \mathrm{~A} \\
852 \mathrm{~A} \text { (fioat) } \\
852 \mathrm{~B} \text { (fioat) } \ldots . . . \\
\end{array}$ & $\begin{array}{l}40 \\
38 \\
39 \\
37\end{array}$ & $\begin{array}{l}24 \\
26 \\
26 \\
22\end{array}$ & $\begin{array}{l}32 \\
33 \\
28 \\
34\end{array}$ & $\begin{array}{ll}4 & 4 \\
3 & \ldots \ldots \ldots \\
5 & \ldots \ldots \ldots \\
6 & -\ldots \ldots \ldots \\
\end{array}$ & $\begin{array}{l}(\mathrm{Mu}) 2 \\
(\mathrm{Mu}) 1\end{array}$ & $\begin{array}{l}2.63 \\
2.63 \\
2.62 \\
2.62\end{array}$ \\
\hline Average ........... & 39 & 24 & 32 & $4 \ldots \ldots$ & 1 & $\overline{2.62}$ \\
\hline
\end{tabular}

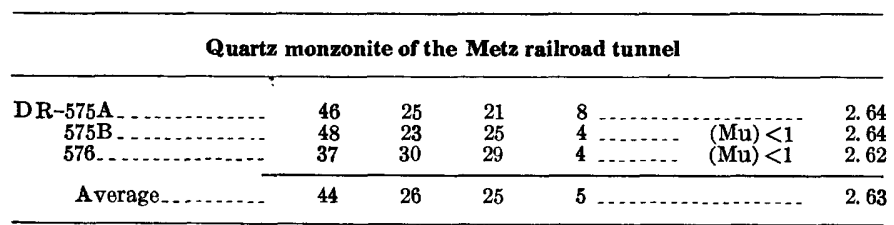

Biotite as irregular, ragged crystals is the only dark mineral found, except for one occurrence of pale-green hornblende in a gneissic rock on Thompson Creek. The pleochroism of the biotite is $\mathrm{X}=$ grayish orange and $Z=$ various shades of dark yellowish brown and grayish brown, and some olive shades.

Zircon is the most widespread accessory mineral, and apatite is also found in nearly all specimens. Sphene and metallic opaque minerals are definitely not common. In several thin sections neither mineral was seen, and where they do occur they tend to be rare.

Alteration is slight in this mass. Minor amounts of sericite in plagioclase, local alteration of biotite to chlorite, and some iron oxide staining mark these generally chemically fresh rocks. Even some of the impressively weathered rocks make notably "clean" thin sections.

\section{Distinguishing Features}

The general physical appearance of these rocks is rather nondescript. Coarse-grained felsic quartz monzo- nite that weathers to shades of yellow and orange has little to distinguish it. The nearest similar-looking granitic rock is the alaskite of Smith Grade in the Ben Lomond area, but that mass has accessory pink garnet, which has not been seen in the Gabilan mass. The rarity of metallic opaque minerals and sphene and the presence of scattered rounded quartz grains, giving an aplitic texture overprint to some specimens, are the only features that seem even possibly distinctive in this mass.

GRANODIORITE OF THE GLORIA-BICKMORE ROAD

Setting and General Description

More than 200 square miles of the central and southern part of the Gabilan Range may be underlain by the granodiorite of the Gloria-Bickmore Road. Exposures are locally fresh, but in much of the area rocks are poorly exposed. Fresh rocks are white to gray and mottled with an average of about 15 percent of dark biotite and hornblende. Most of these rocks are equigranular, but in part they are seriate and contain salmon to pinkish $\mathrm{K}$-feldspar crystals as large as $25 \mathrm{~mm}$. In some rocks coarse hornblende crystals as large as $15 \mathrm{~mm}$ are evident.

The modal plot (fig. $9 C$ ) shows a spread from quartz monzonite to quartz diorite but along a fairly well defined linear trend. Though this modal spread may look excessive for a single intrusive unit, it may reflect a real variation in one unit, not necessarily the presence of multiple intrusions. The best example of this variation is in the excellent roadcut outcrops from which specimen DR-573 was obtained. The rocks there exhibit a marked range in grain size, dark mineral proportions, and feldspar ratio. This range is illustrated in figure $9 E$ and table 6 (specimens 573-1 to 573-8). The most obvious variation in the outcrop is in the dark minerals, which range from exclusively peppery biotite to nearly equal amounts of biotite and euhedral hornblende within short distances. This outcrop also has schlierenlike concentrations of hornblende.

Further detailed fieldwork in 1971 has indeed shown that there are at least two separate intrusive formations in what is called the granodiorite of the GloriaBickmore Road in this report. The "variation" at locality 573 is largely explained by the presence of these two distinctive units.

Where the rock is foliate, the foliation is shown by mineral alinement or the elongation of inclusions and schlieren. Ellipsoidal dioritic inclusions range from abundant to rare; in general the darker more calcic rocks have more inclusions and schlieren. The rather wide variation in amount of inclusion material seems 
to be a characteristic associated with the rather wide range in mineral percentages in this mass.

Near the mouths of Bryant and Stonewall Canyons on the west side of the range, the granitic rocks are strongly foliated, contain abundant schlieren and inclusions, are in part migmatitic, and are associated with schist, calc-hornfels, and quartzite. Up both canyons the rocks assume the appearance of other rocks of the granodiorite of the Gloria-Bickmore Road, and I have concluded that the foliated quartz diorite (represented by samples DR-844, 845, 846, 847-D) is a local contaminated area, not a separate intrusive. The contaminated area may well reflect nearness to the border of the mass and nearness to metamorphosed wallrocks. On the other hand, these foliated rocks could be nearly homogenized remnants of a gneissic terrane.

It is interesting to note the striking resemblance of much of the rock in Bryant Canyon to the rocks of the La Panza Range, where local contamination also appears to be related to large inclusions that are in part schistose. In Stonewall Canyon are rocks that greatly resemble the outcrops of ghost gneiss in the Red Hills; that is, they look more like homogenized gneissic rocks. The Stonewall-Bryant Canyons area thus has suggestions of both contaminated granitic rocks and homogenized gneissic rocks. In essence, both processes can produce similar-looking rocks. The vast areas of homogeneous granitic rock in the Gabilan Range, however, seem to strongly suggest that the Stonewall-Bryant area is a local contaminated granitic area, not that it is the last unhomogenized remnant of a vast granitized terrane.

\section{Microscopic Description}

Most specimens are xenomorphic-granular, but some are seriate with poikilitic $\mathbf{K}$-feldpar crystals as large as $15 \mathrm{~mm}$.

Plagioclase ranges from well-formed, cleanly zoned, and twinned fresh crystals to strongly saussuritized crystals, generally in the andesine range, most commonly sodic andesine. K-feldspar has its usual irregular, engulfing habit. Crystals range from small interstitial masses to poikilitic phenocrysts that are $10-15 \mathrm{~mm}$ long, and they engulf grains of all other minerals. Irregular quartz masses range from very small to $5 \mathrm{~mm}$; most are at least somewhat mosaicked, and some are intricately sutured. Some of the foliated rocks (DR-845, 847-D) contain more quartz than "normal" granitic rocks.

Biotite in irregular ragged shreds tends to cluster with hornblende and accessory minerals. The biotite pleochroism is $\mathbf{X}=$ grayish orange to grayish yellow and $\mathrm{Z}=\mathrm{a}$ considerable range of shades of olive and brown, most commonly moderate olive brown, dark yellowish brown, moderate brown, and grayish brown.
Hornblende also occurs as irregular crystals, but in some rocks where it is abundant it occurs as rather euhedral large crystals. It is pleochroic as follows: $\mathrm{X}=$ moderate greenish, $\mathrm{Y}=$ light olive, and $Z=$ grayish green to moderate, yellowish green. Both biotite and hornblende range from extremely fresh to highly altered masses of chlorite and epidote. Generally biotite is the most altered of the two.

These rocks are characterized by an abundance of metallic opaque minerals, sphene, and epidote. Zircon and apatite are found in nearly all specimens. In some specimens, the abundance of discrete epidote crystals that do not seem to be alterations of dark minerals suggests that at least part of the epidote is primary. Also, some allanite crystals are rimmed with what appears to be primary epidote. Generally, abundant sphene and abundant metallic opaque minerals go together. In these rocks, euhedral sphene crystals include abundant metallic opaque crystals in somewhat Arabiccharacter shapes. One notable exception, however, is specimen 584, which contains about 1 percent euhedral sphene, yet only the merest trace of metallic opaque minerals. Because this rock has 24 percent dark minerals, one would expect it to have abundant metallic opaque minerals. Some specimens of this unit have very small amounts of both sphene and metallic opaque minerals.

\section{Distinguishing Features}

In hand specimen this rock is not particularly distinctive, yet in outcrop the rather rapid textural-structural and mineralogical changes over short distances do seem noteworthy. The abundance of possibly primary epidote is probably the most distinctive feature of this unit. Also the local abundance of euhedral sphene with abundant Arabic-character inclusions of metallic opaque minerals is distinctive.

\section{MISGELLANEOUS ROGKS OF THE GABILAN RANGE}

\section{Quartz Diorite of Vergeles}

At the north end of the Gabilan Range, just south of the Vergeles fault, are outcrops of a quartz diorite that most closely resembles the granodiorite of the GloriaBickmore Road. These rocks are tentatively considered to be a separate intrusive, though there is good reason to believe that they are a Gloria-Bickmore correlative whose original continuity has been interrupted by the quartz monzonite of Fremont Peak. Intrusive into the Vergeles rocks are aplite and fine-grained biotite quartz monzonite. Fine-grained irregular-textured rocks, in part foliated, and possibly hybrid, are also associated with the Vergeles rocks. 
The texture of these rocks is xenomorphic- to hypautomorphic-granular. In part, alined dark minerals and inclusions define a foliation, and one rock, specimen 548 , has an anastomosing fabric shown by sliverlike, highly strained quartz and bent biotite. The plagioclase seems to be mostly sodic andesine that is only slightly altered. K-feldspar is entirely lacking in some specimens and makes up several percent of other specimens. Pronounced, small-scale local variation, as in the quarry of specimen 541, is similar to that in the Gloria-Bickmore rocks. Biotite, the dominant dark mineral, is pleochroic as follows: $\mathrm{X}=$ grayish orange to pale yellow and $Z=$ various shades of olive, yellowish, and moderate brown. Some of the biotite has a reddish color. Hornblende is absent in some rocks and abundant in others, again similar to the Gloria-Bickmore rocks. It is pleochroic as follows: $\mathrm{X}=$ moderate greenish yellow, $\mathrm{Y}$ $=$ light olive, and $Z=$ grayish green to light olive.

Apatite and zircon are found in nearly all specimens. Sphene is common in some, but virtually absent in others. Metallic opaque minerals are generally rare, and allanite is also rare. Epidote is present in all specimens, mostly as an alteration product, but some of it may be primary in specimen 548 .

Too few specimens are available from which to draw conclusions about distinguishing features of this rock. The rock does, however, seem to be rather variable in texture and in dark-mineral ratio; this coincides with other features that suggest it is related to, or is part of, the Gloria-Bickmore mass. The abundance of biotite and the composition of the plagioclase rule out correlation with the Logan quarry rocks (pl. 2), which in part it resembles in the field.

\section{Granodiorite of Grass and Thompson Creeks}

Granodiorite has been examined in two small areas on Grass and Thompson Creeks. Its relation to the surrounding quartz monzonite of Fremont Peak is not known, because of the lack of exposed contacts. The rocks are probably not variants of the Fremont Peak rocks, but they could be part of the Gloria-Bickmore mass. They are medium to fine grained, medium gray, generally equigranular, and have scattered poikilitic Kfeldspar crystals as much as $10 \mathrm{~mm}$ long. Petrographically they are much like the Gloria-Bickmore rocks. Plagioclase, mostly andesine, is most abundant, and K-feldspar engulfs other minerals. Quartz displays undulatory extinction and is mosaicked and sutured. Biotite is pleochroic from $X=$ grayish orange to $Z=$ dark yellowish brown to moderate reddish brown. Hornblende is much less common and is pleochroic in light shades of green. Sphene is abundant; metallic opaque minerals are abundant to rare; and allanite, apatite, and zircon are present. Epidote is abundant in one specimen.

\section{Quartz Monzonite of the Gloria-Bigkmore Road}

Near the east end of the Gloria-Bickmore Road are outcrops of quartz monzonite that contain salmon-colored $\mathbf{K}$-feldspar and grade to a pegmatitic texture. These rocks are in part porphyritic, with $\mathrm{K}$-feldspar phenocrysts as much as $25 \mathrm{~mm}$ long. Contacts were not observed, but presumably these rocks intrude the granodiorite of the Gloria-Bickmore Road. Granitic float in the wash near the east entrance to the Pinnacles National Monument resembles these rocks; thus, there is more of this rock east of the Pinnacles volcanic rocks.

These rocks are composed chiefly of albite to oligoclase plagioclase, poikilitic, engulfing $\mathbf{K}$-feldspar, and strongly sutured and mosaicked quartz. Myrmekite is also common. Biotite is pleochroic from $\mathbf{X}=$ grayish orange to $\mathrm{Z}=$ moderate yellow brown to opaque. Muscovite, minor metalic opaque minerals, zircon, and apatite are present, but sphene seems to be lacking.

\section{Quartz Monzonite of the Metz Railroad Tunnel}

Quartz monzonite that is exposed near the Metz railroad tunnel is characterized by a somewhat aplitic texture, with quartz "droplets" scattered throughout the specimens to give stained surfaces a rather fuzzy look. Though these rocks are somewhat different in appearance from the quartz monzonite of the Gloria-Bickmore Road, they seem to have a similar setting: both seem to be late felsic plugs into the granodiorite of the GloriaBickmore Road.

These rocks have little to distinguish them, beyond the "subaplitic" texture and the presence of muscovite. They contain metallic opaque minerals, but virtually no sphene.

\section{GRANITIC ROCKS IN ISOLATED FAULT SLIVERS BETWEEN THE GABILAN RANGE AND GOLD HILL}

GRANITIC ROGKS OF STOCKDALE MOUNTAIN

Setting and General Description

Small outcrops of granitic rock protrude through Miocene volcanic and nonmarine sedimentary rocks about 1 mile west of the main trace of the San Andreas fault, near the north end of Cholame Valley. These granitic rocks, separated from the La Panza Range by a vast sea of Plio-Pleistocene nonmarine deposits, are nevertheless somewhat similar to the granitic rocks of La Panza Range.

Medium-light-gray medium-grained rocks of peppery 
texture that are only weakly seriate make up these exposures. In part the $K$-feldspar is pinkish to salmon colored, but generally these rocks, where fresh, are shades of gray.

The San Luis Obispo geologic map sheet (Jennings, 1959 ) shows a belt of granitic outcrop that is separated into three parts by alluvium. Specimen 142 was collected from the north end, and specimens 143 and 145 were collected from the south end of the northernmost. segment. The middle and south segments were not examined.

The modal data (table 7; fig. 10) show a considerable spread, but the compositional spread and the average are not too different from those of the La Panza granitic rocks.

In the area of specimens 143 and 145, there is a prominent knob, several hundred feet across, of coarse-grained calcite marble. The marble is considerably brecciated, but irregular bedding is visible at the south end of the outcrop. Metamorphic minerals are present; the most common are grossularite garnet, with an index of refraction of about 1.760, and colorless to pale-yellow mica, probably phlogopite, that is biaxial negative with a very low $2 \mathrm{~V}$ and a beta index of about 1.585 .

\section{Microscopic Description}

The northernmost sample (specimen 142) is somewhat coarser than the other granitic rocks of this area. It is hypautomorphic-granular and contains quartz that does not seem to be as sutured and mosaicked as quartz in
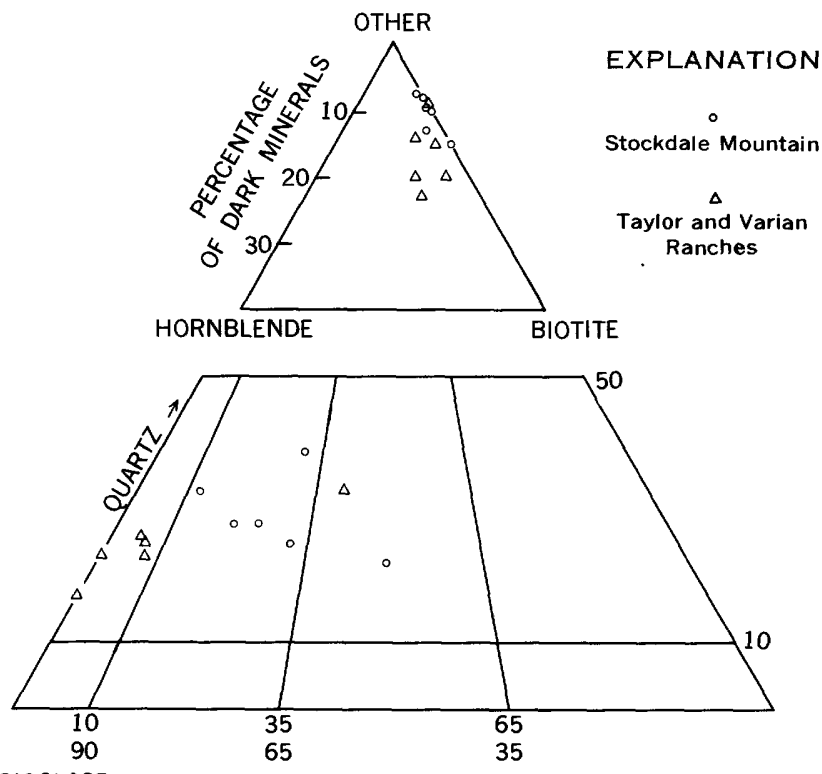

PLAGIOCLASE

K-FELDSPAR

Figure 10.-Modal plot of granitic rocks of Stockdale Mountain, and Taylor and Varian Ranch fault slivers.
TABLE 7.-Modes of granitic rocks of Stockdale Mountain and fault slivers of Taylor and Varian Ranches

$[S=$ sphene, n.d. $=$ not determined, $T r .=$ trace]

\begin{tabular}{|c|c|c|c|c|c|c|c|}
\hline No. & $\begin{array}{l}\text { Plagi- } \\
\text { oclase }\end{array}$ & $\underset{\text { feldspar }}{\mathbf{K} \text { - }}$ & Quartz & $\underset{\text { tite }}{\text { Bio- }}$ & $\begin{array}{l}\text { Horn- } \\
\text { blende }\end{array}$ & Other & $\begin{array}{l}\text { Specific } \\
\text { gravity }\end{array}$ \\
\hline \multicolumn{8}{|c|}{ Stockdale Mountain } \\
\hline $\begin{array}{r}\text { DR-142A } \\
143 \mathrm{~A} \\
143 \mathrm{~B} \\
145 \mathrm{~B} \\
145 \mathrm{C}-\ldots, \\
145 \mathrm{D}\end{array}$ & $\begin{array}{l}48 \\
38 \\
49 \\
48 \\
46 \\
37\end{array}$ & $\begin{array}{r}17 \\
17 \\
7 \\
13 \\
21 \\
\mathbf{3 5}\end{array}$ & $\begin{array}{l}25 \\
35 \\
28 \\
24 \\
22 \\
20\end{array}$ & $\begin{array}{r}10 \\
8 \\
15 \\
11 \\
9 \\
7\end{array}$ & Tr. & (S) 1 & $\begin{array}{l}2.68 \\
\text { n.d. } \\
\text { n.d. } \\
2.71 \\
\text { n.d. } \\
\text { n.d. }\end{array}$ \\
\hline Average_. & 44.5 & 18.5 & 26 & 10 & Tr. & 1 & (n........... \\
\hline
\end{tabular}

\begin{tabular}{|c|c|c|c|c|c|c|}
\hline \multicolumn{7}{|c|}{ Taylor and Varian Ranchea } \\
\hline $\begin{array}{r}\text { DR-1065-1.. } \\
1066 \\
1067 \mathrm{~A} \\
1067 \mathrm{~B} \\
1068 \\
1070 \\
1070\end{array}$ & $\begin{array}{l}57 \\
64 \\
60 \\
60 \\
\mathbf{3 6} \\
\mathbf{6 2}\end{array}$ & \begin{tabular}{r}
5 \\
\hdashline 3 \\
4 \\
25 \\
---
\end{tabular} & $\begin{array}{l}18 \\
13 \\
22 \\
22 \\
30 \\
18\end{array}$ & $\begin{array}{r}17 \\
15 \\
13 \\
10 \\
9 \\
13\end{array}$ & $\begin{array}{l}3 \\
3 \\
8\end{array}$ & $\begin{array}{l}2.75 \\
2.78 \\
2.71 \\
2.74 \\
2.67 \\
2.74\end{array}$ \\
\hline
\end{tabular}

specimens of granitic rocks from the La Panza Range. Plagioclase is about $\mathrm{An}_{30}$. The $\mathrm{K}$-feldspar, in part, has grid twinning, but some is very patchy. Biotite is relatively abundant. It occurs as 2- to 4-mm-sized grains and thus is different from the shredlike peppery biotite in other Stockdale Mountain specimens. Pleochroism ranges from $\mathrm{X}=$ grayish yellow to $\mathrm{Z}=$ light olive to moderate olive brown. In the accessory minerals the only noteworthy feature is possible primary epidote in discrete crystals, not obviously connected with any alteration.

The specimens from the south end of the northernmost band of outcrop (specimens 143, and 145) more closely resemble the Ia Panza granitic rocks. They are medium light gray, peppered with dark minerals, and are in part weakly seriate. Thin sections show a good granitic texture with sutured, mosaicked, and somewhat granulated quartz. Plagioclase is unaltered, well twinned, and zoned generally in the sodic andesine range. $\mathbf{K}$-feldspar is in part grid twinned and engulfs other constituents. Myrmekite is present at some contacts between plagioclase and K-feldspar. Biotite occurs as small irregular flecks and is only slightly chloritized. It is pleochroic from $\mathrm{X}=$ grayish yellow to $\mathrm{Z}=$ light olive to moderate yellowish brown. This is somewhat more olive and less brown than biotite from the La Panza Range. Green hormblende is present in only one specimen and is pleochroic as follows: $\mathbf{X}=$ moderate greenish yellow, $\mathrm{Y}=$ dark yellowish green, and $\mathrm{Z}=$ grayish green. The usual accessories, apatite, allanite, zircon, sphene, and metallic opaque minerals, are present. Discrete crystals of epidote also appear to be primary, which seems plausible because these rocks show little alteration. Sphene is particularly abundant and is liberally studded with inclusions of metallic opaque minerals. 
QUARTZ DIORITE OF TAYLOR AND VARIAN RANGHES

Setting and General Desgription

East of the Stockdale Mountain occurrences are two areas of granitic rock that are presumably fault slivers in the San Andreas fault zone. The southernmost, at Taylor Ranch (pl. 2), is poorly exposed and deeply weathered. Some marble is associated with the rocks there. The northernmost, at Varian Ranch, is fairly fresh and well exposed. From the small areas examined there is reason to suspect that the major rock type is the same in the two areas.

The freshest rocks are distinct in texture, with abundant coarse irregular black biotite and hornblende crystals as large as $10 \mathrm{~mm}$ across in a white matrix of feldspar and quartz. Primary foliation is shown by alinement of dark minerals. The outcrops show abundant shearing and shattering, although fresh unsheared rocks are present as blocks. Some felsic material intrudes these rocks. The modes show a good grouping in figure 10 and table 7, except for specimen 1068, which is more gneissic than the other specimens. The general appearance of these rocks is quite different from that of nearby granitic outcrops in the southern Coast Ranges. In physical appearance these rocks are most like some of the quartz diorite with coarse biotite books and hornblende crystals that crops out in the central Coast Ranges at Ben Lomond and Tomales Point.

\section{Migroscopic Desgription}

These rocks have a granitic texture, but most exhibit considerable strain as shown by strongly sutured, mosaicked, and slivered quartz, as well as by bent biotite and plagioclase crystals. Plagioclase is well twinned and zoned in the andesine range. In some specimens the plagioclase is completely altered. $\mathbf{K}$-feldspar is generally minor. Most occurs as late veinlets or as small irregular interstitial grains. Even in specimen 1068 the highest concentration of $\mathrm{K}$-feldspar is in a band that may be intrusive or may have been sweated out at a later time.

Biotite where fresh is pleochroic from $X=$ grayish orange to $\mathrm{Z}=$ moderate brown. Hormblende is somewhat less abundant and is pleochroic from $\mathrm{X}=$ moderate greenish yellow to grayish yellow green, to $\mathrm{Y}=$ light olive, to $Z=$ dark yellowish green. Both biotite and hornblende are irregular and poikilitic at thin-section scale, but in hand specimen some of the hornblende looks euthedral.

Sphene is the most common accessory, but zircon, apatite, and allanite are also present. Metallic opaque minerals appear to be rare and to be restricted to small sprinklings in hornblende, a habit they have in common with the central Coast Ranges outcrops.

\section{Distinguishing Features}

The coarse, abundant biotite and hornblende crystals distinguish this rock from any nearby basement occurrence. The general sparsity of $\mathrm{K}$-feldspar and its presence as interstitial grains as well as late veinlets are also noteworthy. The rarity of opaque minerals and their restriction to the hornblende crystals may also be significant. All these features suggest the similarity of the Taylor and Varian Ranches occurrences to the central Coast Ranges granitic outcrops.

\section{GNEISSIC ROGKS OF RED HILLS}

\section{SETTING AND GENERAL DESGRIPTION}

Gneissic basement rocks protrude through the Tertiary cover in a number of places in the Red Hills over an area about 1 mile wide and 3 miles long. About 1 square mile of basement outcrop is present in these hills, which are named for the distinctly colored Tertiary clastic rocks that are exposed there. The Red Hills basement outcrops are about 5 miles west of the San Andreas fault, and they are immediately east of, and in part butt into, a prominent fault zone named in its different parts the Red Hills fault, San Juan fault, and Chimeneas fault.

Generally, exposures are poor and the basement rocks are weathered, but fairly fresh exposures are present in stream valleys and locally on hillsides. A variety of rock types is exposed, but most common is a mediumgrained medium-dark-gray gneissic rock with a quartz diorite composition. Augen gneiss, biotite-rich gneiss, and amphibolite are less common, and there is one layer of coarse-grained graphite-flecked marble. Coarsegrained granitic pegmatite with abundant salmoncolored $\mathbf{K}$-feldspar occurs as dikes and sills as well as in irregular patches that grade into the gneissic rock.

A rather consistent foliation, which generally strikes northwest and dips moderately to steeply southwest, marks these outcrops. Where exposures are good, areas of homogeneous granitic-looking rock grade into gneissic rocks, and patchy gneissic rocks are included in homogeneous granitic-looking rocks. The gneissic bands, where best developed, are from half an inch to several inches thick. On close observation even surficially homogeneous granitic-looking rocks are in part gneissic. Specimen 100 shows this by the distribution of $\mathrm{K}$ feldspar-rich layers alternating with $\mathrm{K}$-feldspar-poor layers on stained specimens that look homogeneous or only vaguely foliated in hand specimen.

In part the gneissic layering is sharp and well defined. However, the layers are generally less sharp than, for example, the gneiss at Barrett Ridge, farther south. Gradational variation from well-defined gneissic 
layering to homogeneous granitic-looking rocks is characterized by intermediate stages that $I$ refer to in the field as ghost gneiss. Subtle patchy gneissic areas in granitic rocks suggest that a homogenization process has converted gneissic rocks to a granitic-textured rock. The grossly layered sequence of quartz diorite gneiss, amphibolite, biotite-rich gneiss, marble, and augen gneiss suggests that this is a highly metamorphosed pile of sedimentary rocks (plus possibly volcanic rocks).

Modes of several of the gneisses are listed in table 8 and are plotted in figure 11. Though there is variation, the general grouping of points suggests that most of the gneiss has a quartz diorite composition with rather abundant quartz. Only one gneiss specimen departs markedly from this grouping. Specimen 100, selected in the field as an example of the homogeneous, graniticlooking rocks of the Red Hills, has remarkably well defined gneissic bands an inch or more wide. Layers alternately rich in and nearly devoid of $\mathrm{K}$-feldspar have a mineral content as given in table 8 . The alternation is chiefly in the plagioclase and $K$-feldspar, as the variation of quartz and mafic minerals is not significant. This layering is hard to account for. It was probably "inherited," but both the segregation and the abundance of $\mathrm{K}$-feldspar are uncommon in the Red Hills.

\section{MICROSCOPIC DESGRIPTION}

The basement rocks of the Red Hills can be grossly divided into three categories: (1) granitic-looking rocks that are generally gneissic, (2) augen gneiss, and (3) amphibolite, pegmatite, and other miscellaneous types.

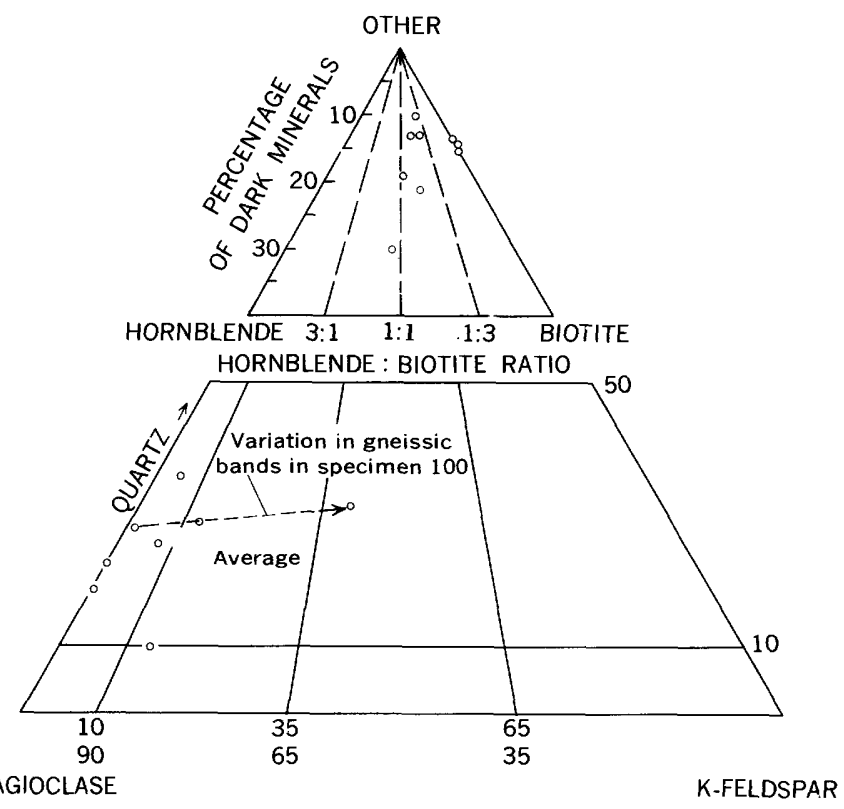

Froure 11.-Modal plot of gneissic rocks of Red Hills.
TABLE 8.-Modes of gneissic rocks of Red Hills

[Ac=accessory minerals, $\mathrm{S}=$ sphene, $\mathrm{Al}=$ allanite, $\mathrm{Tr}=$ trace]

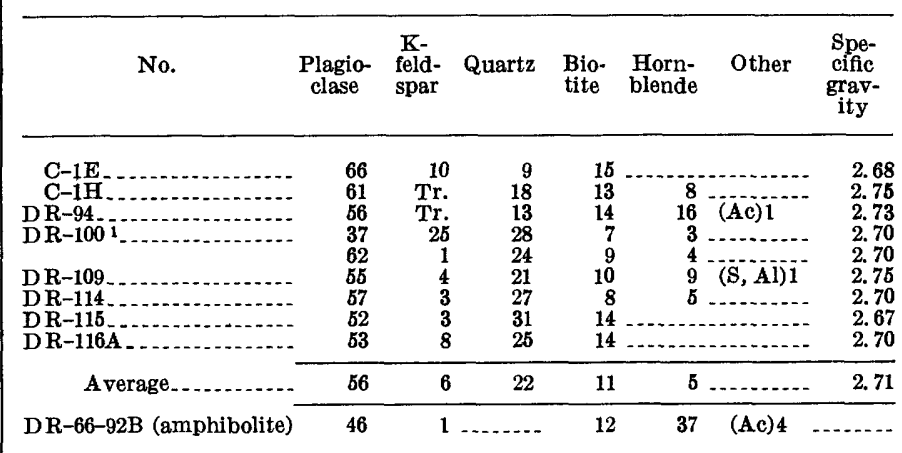

1 Variation in gneissic layers.

Gneissig Granitic Rogks or Granitic Gneiss

The most common, and characterizing, rocks of the Red Hills basement are gneissic rocks of granitic composition and, in part, appearance. These rocks although generally somewhat gneissic in outcrop, are rarely obviously gneissic in thin section. In part an alinement of dark minerals outlines a foliation, but generally the texture is xenomorphic- to hypautomorphicgranular so that from thin section texture alone these rocks are granitic.

Plagioclase, the most abundant mineral, is generally relatively unaltered, well twinned, and zoned in the andesine range. The andesine is generally only weakly dusted with alteration products or has minor saussuritization, though locally alteration is intense.

$\mathrm{K}$-feldspar is much subordinate to plagioclase and occurs mostly as irregular interstitial grains, but some crystals are as large as the plagioclase crystals. The $\mathrm{K}$ feldspar in these rocks does not have microcline grid twinning.

Irregular interstitial masses of quartz are generally rather abundant in these rocks. The quartz is highly sutured and mosaicked. Rarely is there much granulation or milling down of the quartz masses, but the evidence of highly strained rocks is compelling. Stretchedout crystals of quartz show deep, intricate suturing and interlocking mosaicking of variably oriented crystal segments.

Both biotite and hornblende are generally abundant, but the ratio between them varies; hornblende is even missing in some specimens. Though some dark minerals, particularly hornblende, occur as well-formed crystals, the dark minerals are, in general, shredlike or irregular. In some rocks the dark minerals are strung out to define a foliation. Most of the biotite and hornblende is fresh, but partial alteration or complete pseudomorphing by chlorite and epidote is impressive in some specimens. Both minerals are strongly pleochroic. The brown biotite has the following pleochroism: $\mathrm{X}=$ 
grayish orange to grayish yellow and $\mathrm{Z}=$ moderate brown to grayish brown. The green hornblende has the following pleochroism: $\mathrm{X}=$ moderate greenish yellow, $\mathrm{Y}=$ light to grayish olive and dark yellowish green, and $Z=$ dark yellowish green and grayish green.

Almost all specimens contain small amounts of zircon, sphene, apatite, allanite, and metallic opaque minerals. Hematite is less common, and in some specimens leucoxene is present as an alteration of sphene. The amount of metallic opaque minerals seems anomalously low for rocks in which dark minerals are so abundant.

Probably the most distinctive features of these rocks are (1) the vague to prominent gneissic character of large specimens or outcrops, (2) the intense suturing and mosaicking of the quartz, and (3) the sparsity of metallic opaque minerals.

\section{Augen Gneiss}

In thin section the augen gneiss has a granoblastic texture of sutured, mosaicked, and stretched-out granulated quartz masses. Trains of biotite, the only dark mineral, also help define the structure. The largest, most distinct eyes are generally $\mathrm{K}$-feldspar, though plagioclase is also present in some less-sheared pockets.

Plagioclase and K-feldspar are present in about equal amounts. Plagioclase is in the range from calcic oligoclase to sodic andesine, and it is well twinned, generally fresh, and zoned. Biotite is pleochroic from $X=$ grayish yellow and grayish orange to $\mathrm{Z}=$ grayish brown. It is only slightly chloritized; most flakes are fresh.

The same accessory minerals are present as in the other Red Hills rocks, except for sphene. In one specimen, rounded zircon grains up to $0.1 \mathrm{~mm}$ in diameter suggest a detrital source.

\section{Misgellaneous Rock Types}

Rocks of the third category-amphibolite, hornblende schist, dioritic hornblende pegmatite, granite pegmatite, and marble, as well as some miscellaneous gneiss or hornfels rich in dark minerals-cover a small total area.

These rocks, with the exception of the granite pegmatite and of course the marble, have the same essential mineralogy as the bulk of the gneiss of Red Hills. Their compositions range from quartz diorite to diorite with andesine plagioclase. The dark minerals, in varying proportions, have the same general character and pleochroism as those in the gneisses. One exception is a schistose rock with pale-green amphibole that may be actinolitic.

A distinctive rock in the Red Hills is the granite pegmatite, in which moderate-orange-pink $\mathbf{K}$-feldspar in coarse crystals dominates and makes a sharp contrast with the generally somber gray gneiss. These pegmatitic rocks were definitely mobile and intrusive in part, but they also occur as coarse-grained patches that grade into the surrounding rocks, as if they were sweated out of the gneiss.

A tongue of coarse-grained calcite marble about 200 feet wide and 500 feet long is present in the northernmost Red Hills basement outcrop. This rather nondescript rock has minor silty layers; they define bedding and are generally alined with the gneiss foliation. Graphite flakes speckle the marble, but calc-hornfels layers appear to be absent.

Summary of Petrographic Character of Red Hills Gieiss

The typical basement rock of the Red Hills is a faintly to strongly gneissic rock of generally quartz diorite composition. The pervasive gneissic structure, so evident in outcrop, is generally not reflected in thin sections, except in a most subtle way. Rather intense strain effects are shown by sutured, mosaicked quartz. Many of the more homogeneous granitic-looking specimens have a rather hard-to-define granular appearance that seems to result because generally well-formed plagioclase crystals float in a matrix of other constituents; this floating appearance is accentuated in weathered outcrops. Perhaps this rather subtle textural feature is distinctive of the Red Hills gneiss.

No particular mineral seems distinctive in the Red Hills exposures. Possibly the paucity of metallic opaque minerals in rocks with a fairly high percentage of dark minerals will serve to differentiate these rocks from some other basement rock units.

\section{GRANODIORITE-QUARTZ MONZONITE OF THE LA PANZA RANGE}

SETTING AND GENERAL DESCRIPTION

Granitic basement rocks are exposed throughout an area of some 100 square miles in the La Panza Range east of Santa Margarita. The rocks are overlapped by Cretaceous and Cenozoic sedimentary units and are probably truncated against a branch of the Nacimiento fault on the west and against the Red Hills-San JuanChimeneas fault on the east. About 1 square mile of presumably correlative granitic rock is exposed northwest of Paso Robles (specimen A-1), and the granitic rocks on San Juan Creek are probably also part of the same mass. The La Panza Range is rather heavily covered with brush and timber, and exposures are generally poor and rather deeply weathered. Some surprisingly good outcrops, however, are present and furnish relatively fresh samples. Reconnaissance sampling so far suggests that the La Panza Range granitic basement is one rather homogeneous intrusive body.

The granitic rocks are generally medium light gray 
to medium gray where fresh, but weathered specimens tend to be shades of orange and yellow. A mediumgrained groundmass is commonly studded with $\mathrm{K}$-feldspar crystals as large as $40 \mathrm{~mm}$ across giving a prominent seriate texture to many outcrops. In some outcrops the coarser $\mathrm{K}$-feldspar crystals are absent and the rocks are equigranular; no distribution pattern has yet been seen for these large crystals. In general the granitic rocks have a peppery texture with a liberal sprinkling of small biotite flakes. Inclusions are not common, but some are several feet long, biotite rich, and in part schistose. Large inclusion masses near La Panza are as much as 75 feet across and are composed of about the same material. Light-colored aplite, alaskite, and simple pegmatite are relatively common; some dikes are several feet thick, but most are only a few inches thick. In the vicinity of specimens $\mathrm{P}-6$ and SLO-2, in the northwestern part of the range, some large masses of alaskite and aplite of unknown size intrude the granitic rocks. A small mass of coarse-grained calcite marble is included in the granitic rocks near $\mathrm{P}-6$. In general, however, xenolithic material is scarce.

In the field, foliation was noted at only a few outcrops, where schlieren, or inclusions, or minerals (particularly $\mathrm{K}$-feldspar) were alined. However, staining of the numerous slabs that were used for modal analysis showed that mineral alinement is more common than field observations suggested.

Modal data on specimens from this mass are given in table 9 and plotted in figure 12. The relatively compact modal field indicates a suite of related rocks. The general trend shows essentially the same quartz content throughout the mass, except for some rocks that are possibly contaminated.

\section{MICROSCOPIC DESGRIPTION}

The granodiorite-quartz monzonite is generally xenomorphic- tó hypautomorphic-granular to seriate. As already noted, foliation caused by mineral alinement is relatively common. Some sheared, granulated zones were noted in thin section, but mostly intricately sutured, mosiacked, and somewhat granulated quartz identifies the effects of some strain in these rocks. Bent, kinked, and somewhat crumpled biotite flakes and broken plagioclase crystals with minor saussuritization along the cracks also point out some cataclastic effects.

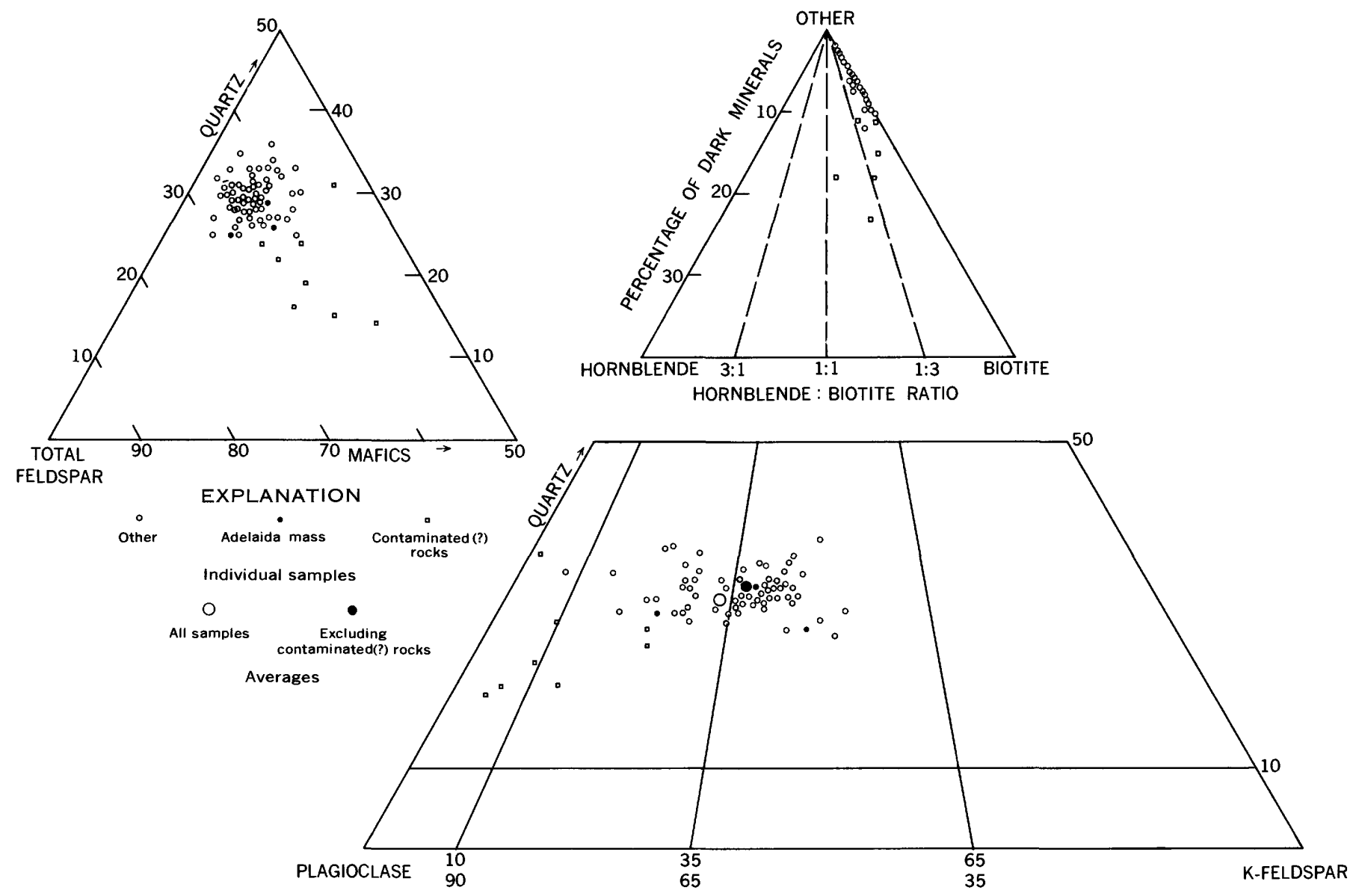

Frgure 12.-Modal plot of granodiorite and quartz monzonite of the La Panza Range. 
$\mathrm{T}_{\mathrm{ABLE}}$ 9.-Modes of granodiorite-quartz monzonite of the La Panza Range

[Samples A-1 to DR-1157A from Adelaida mass; samples B R-6-3A to DR-1156 contaminated(?); n.d.= not determined; Tr. =trace]

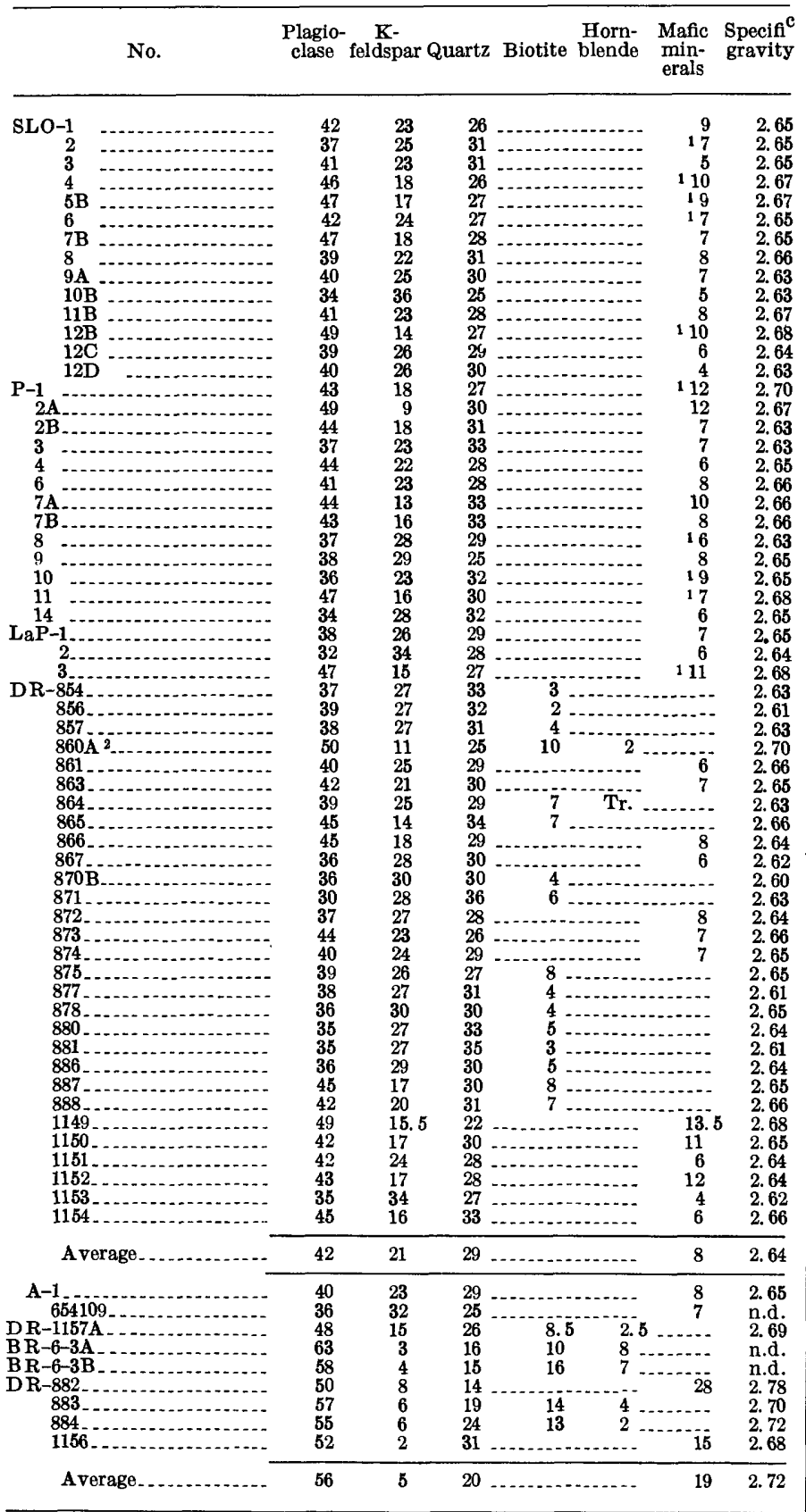

1 Less than 1 percent green hornblende.

2 Mode includes metallic opaque minerals, 1 , and sphere, 1

Plagioclase is well twinned; much of it occurs as well-formed crystals which in part have oscillatory zoning and are relatively unaltered. The most calcic zones are generally sodic andesine. $\mathbf{K}$-feldspar is abundant and locally perthitic and does not show grid twinning. It has very impressively engulfed all the other constituents of the rock. It is commonly myrmekitic against the plagioclase. The most common inclusions in the
$\mathrm{K}$-feldspar are nearly euhedral crystals of plagioclase, which in part are alined along growth lines of the $\mathrm{K}$-feldspar. Clearly $\mathrm{K}$-feldspar is the latest mineral to crystallize in these rocks, for it looks porphyroblastic and appears to have grown at the expense of all the earlier formed minerals. Biotite makes up 5-10 percent of most rocks. It occurs as small irregular flecks that are partly altered to chlorite. The biotite pleochroism is generally $\mathrm{X}=$ grayish orange and $\mathrm{Z}=$ moderate brown, moderate olive brown, or dark yellowish brown. Green hornblende is also present in trace amounts, as irregularshaped crystals, in some specimens.

The accessory minerals present are sphene, apatite, zircon, allanite, possibly primary epidote, and metallic opaque minerals. Allanite crystals, deeply pleochroic in shades of brown and as large as $0.5 \mathrm{~mm}$, are particularly noticeable. Some of the sphene is intergrown with metallic opaque material.

Yellowish-gray alaskite and aplite in this mass look much like similar rocks elsewhere. About the only possibly distinctive feature found was a trace of red garnet in one specimen.

\section{INGLUSIONS AND RELATED ROGKS}

Dark-gray medium- to fine-grained inclusions are not common, but are locally present; a few occur in swarms. Some isolated inclusions are several feet long; one mass as large as 75 feet across was found near La Panza. Most inclusions are diorite or quartz diorite and contain both biotite and hornblende; however, some have only biotite. Some are massive, and others are notably schistose. The schistose inclusions appear to be related to a metamorphic rock, whereas the massive ones have an essentially granitic fabric. The inclusions seem to be in general equilibrium with the granitic rocks, as far as composition of plagioclase is concerned. Also, the biotite and the hornblende of the inclusions are similar in general habit, color, and pleochroism to the dark minerals of the granodiorite-quartz monzonite. The granitic rocks around a large inclusion mass near La Panza seem to be contaminated, for they are quartz diorite. Two specimens (BR-6-3A, 3B) whose modes plot considerably away from the main modal field (fig. 12) are not exposed in contact with inclusion material, but they are close to large masses of biotite schist. Also, they look like the darker contaminated rocks near the large inclusion near La Panza. South of La Panza, in the area of specimens 882,883 , and 884 as well as in the isolated outcrop east of the main mass near La Panza, the rocks are also darker and low in K-feldspar. In the area between specimens 878 and 880 , mica schist interleaved with granitic rocks is exposed in roadcuts, and biotite-rich streaks in the granitic rocks are parallel to 
the schist layering. This apparent contamination of the granitic rock with schistose metamorphic material probably also explains the biotite-rich streaks elsewhere in the granitic mass that are not obviously associated with metamorphic rocks.

That all these presumably contaminated granitic rocks, the inclusion masses, and the micaceous schist seem to be concentrated near the east end of the La Panza granitic outcrop indicates nearness to significant amounts of metamorphic rocks that are not now exposed.

\section{DISTINGUISHING FEATURES}

The strikingly homogeneous granitic rocks of the La Panza Range are probably most distinguished by their texture. The peppery texture, combined with the seriate nature in many areas, produces a distinctive rock. $\mathbf{K}$-feldspar seems to entirely lack grid twinning in this mass also.

\section{QUARTZ MONZONITE OF SAN JUAN GREEK}

SETTING AND GENERAL DESCRIPTION

Five small exposures of basement rocks protrude through the Cenozoic rocks along San Juan Creek (sec. 25 , T. 30 S., R. 17 E.) about $31 / 2$ miles southeast of the extensive granitic basement exposures in the La Panza Range. The total area of the exposures is about half a square mile. The San Juan Creek exposures are also only about 3 miles northwest of the gneissic rocks of Barrett Ridge, but they are on the opposite side of the Chimeneas fault. The smallest, northernmost outcrop is marble; the others are granitic rock.

The San Juan Creek granitic rocks are medium-gray to medium-light-gray felsic quartz monzonite in which sparse biotite is the only dark mineral. Outcrops are sparse and generally much weathered. To date, only the granitic rock in the largest outcrop has been sampled. It varies somewhat from medium fine grained to coarse grained. Modes of four specimens that represent the textural range of the largest granitic outcrop are given in table 10 , and the quartz and feldspar values, recalculated to 100 percent, are plotted in figure 13 . These rocks are quartz monzonite and have a rather low specific gravity because of low dark-mineral content (and also possibly their degree of weathering).

Irregular biotite-rich inclusions in the quartz monzonite are locally present and are as large as several feet across. These inclusions resemble similar biotite-rich inclusions of the La Panza Range granitic rocks. As in the La Panza Range, these inclusions are large, irregular, and sparse in normal occurrence.

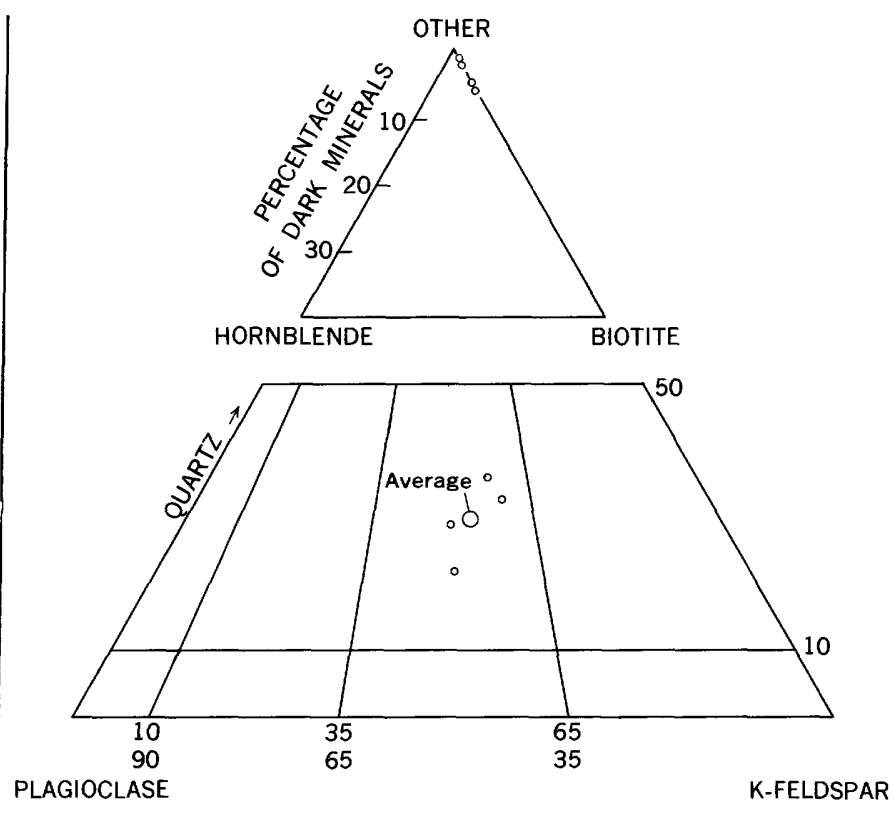

Figure 13.-Modal plot of quartz monzonite of San Juan Creek.

TABLE 10.-Modes of quartz monzonite of San Juan Creek

\begin{tabular}{|c|c|c|c|c|c|}
\hline No. & $\begin{array}{l}\text { Plagio- } \\
\text { clase }\end{array}$ & $\begin{array}{c}\text { K-feld- } \\
\text { spar }\end{array}$ & Quartz & Biotite & $\begin{array}{l}\text { Specific } \\
\text { gravity }\end{array}$ \\
\hline $\begin{array}{r}D R-66-63 A \\
66-64 \\
66-66 \\
\quad 66-67 \\
\end{array}$ & $\begin{array}{l}27 \\
34 \\
28 \\
37\end{array}$ & $\begin{array}{l}39 \\
33 \\
35 \\
37\end{array}$ & $\begin{array}{l}32 \\
26 \\
35 \\
21\end{array}$ & $\begin{array}{l}2 \\
5 \\
2 \\
5\end{array}$ & $\begin{array}{l}2.61 \\
2.60 \\
2.61 \\
2.62\end{array}$ \\
\hline Average..... & 32 & 36 & 29 & 3 & 2.61 \\
\hline
\end{tabular}

The marble is rather nondescript white to light-gray thinly bedded coarsely crystalline calcite. The small exposure is almost isolated, but below one part of it a small amount of granitic rock and pegmatite appear to be in contact with the marble. Presumably, the marble is a pendant or an inclusion in the granitic rock.

The San Juan Creek granitic rocks are grossly similar in appearance to some La Panza Range granitic rocks. The main difference is that the San Juan Creek specimens are equigranular, whereas many La Panza Range granitic specimens are seriate. Modes show that the San Juan Creek rocks are more felsic and have a higher proportion of K-feldspar than La Panza Range rocks.

The San Juan Creek granitic rocks are probably part of the La Panza Range granitic mass, but are now isolated from it by Tertiary cover. Interestingly enough, the nearest specimen of the La Panza mass for which there is a mode $(\mathrm{LaP}-1)$ is a quartz monzonite similar to the San Juan Creek rock in modal composition and general appearance. Though somewhat seriate, LaP-1 is not as coarsely seriate as La Panza Range specimens to the west. Although the present data are inconclusive, 
most likely the quartz monzonite of San Juan Creek is the easternmost outcrop of the La Panza Range mass, and most likely this granitic massif is cut off by the Chimeneas fault.

\section{MICROSCOPIG DESGRIPTION}

In thin section these rocks have a xenomorphicgranular texture; the finer grained variety is almost aplitic. Distinctive features are lacking in these rocks. The sodic plagioclase is generally only slightly altered, and twinning is not distinct.

The $\mathbf{K}$-feldspar, which is in part perthitic and lacks grid twinning, is in irregular grains that in part engulf other constituents, particularly plagioclase. Myrmekite pods are locally common; in one specimen rather unusual widely scattered quartz "worms" mark the myrmekite pods. Small amounts of brown biotite are pleochroic as follows: $\mathrm{X}=$ grayish orange to grayish yellow and $\mathrm{Z}=$ moderate yellowish brown to moderate brown. Minor amounts of metallic opaque minerals, apatite, and zircon are also present. One specimen (DR-66-66) has an unusual abundance of zircon, broken as well as euhedral.

\section{GNEISS AND ALASKITE OF BARRETT RIDGE}

SETTING AND GENERAL DESGRIPTION

About 7 miles southwest of Soda Lake in the Carrizo Plain is a 6-mile-long outcrop of gneiss, quartzite, and alașkite, associated with fault horses of marble. The gneiss is well exposed along Barrett Creek, and the other rock types occur on the elongate ridge that is cut by the creek. About 4 square miles of basement rock is exposed; about 1 square mile at the south end is an aplite and alaskite intrusion in the gneiss, and the remainder of the outcrop area is dominantly gneiss.

The west side of the elongate exposure is cut off by the Chimeneas fault. Cretaceous and Tertiary sedimentary rocks butt against the basement along this fault. The outcrop pattern indicates that the basement has been faulted up against the younger sedimentary rocks with considerable dip-slip displacement. A line of marble horses strung out for more than 3 miles along the Chimeneas fault also suggests strike-slip movement along this zone. Presumably the Chimeneas-San Juan-' Red Hills fault is a significant structural feature that superimposes distinctive and different basement rock suites against each other. Along the east side of the basement, Tertiary rocks lap up on the basement with generally gentle dips.

The strongly foliated gneiss generally strikes northwest to west with gentle to intermediate north ward dips. Minor folds, some rather intricate, were noted, but no
GNEISSIC ROCKS, SAN ANDREAS FAULT, CALIF.

major folds were recognized. Some of the dip reversals near the fault may well be drag effects. It seems likely that the three large lenses of quartzite were originally part of one layer in this sequence. The distribution of the marble indicates that it has been smeared out along the fault, and it cannot be assumed to be part of this same sequence. The alaskite-aplite mass is crosscutting and definitely intrudes the gneiss sequence. Dikes and sills of aplite, alaskite, or pegmatite are also common in the gneiss. In addition, granitic-looking pods grade out into the gneiss, as if they were sweated out of the gneiss. We cannot at present say how much of the granitic material is essentially ultrametamorphosed gneiss that has moved only a short distance. The shape of the basement outcrop appears to be controlled by the Chimeneas fault rather than the strike of the resistant gneiss. The riblike ridge exposure which parallels the fault is at an angle to the strike of the gneiss.

\section{MIGROSGOPIC DESGRIPTION}

\section{GNeISS}

These rocks are dominantly quartzo-feldspathic gneiss that grades with increase in dark minerals to biotite-rich gneiss and less commonly to biotite and hornblende schist. A granoblastic fabric typifies these rocks, but the minerals clearly display preferred orientations, particularly biotite. Most specimens have some cataclastic features, and some are augen gneiss with anastomosing trains of feldspar, quartz, and biotite molded around more resistant feldspar eyes. Deeply sutured and intricately mosaicked quartz and rounded quartz grains scattered through some feldspar crystals indicate cataclasis and rehealing. Locally, the gneiss grades into medium-grained strongly oriented schist in rocks particularly rich in biotite or hornblende.

Plagioclase, K-feldspar, quartz, and minor biotite make up the felsic gneiss. An increase in biotite and the appearance of hornblende mark the darker layers. The plagioclase is clean, sharply twinned, zoned, and in the oligoclase-andesine range. The $\mathrm{K}$-feldspar shows no twinning, but it is somewhat perthitic and locally myrmekitic against plagioclase. The ratio of plagioclase to K-feldspar varies widely, and some of the darker biotite-rich layers are particularly rich in K-feldspar. Biotite, generally well oriented in the gneissic banding or schistose layering, is mostly pleochroic from $\mathrm{X}=$ grayish yellow to $\mathrm{Z}=$ light to moderate brown and yellowish brown. Hornblende is present only locally, but is abundant in some hornblende schist. It looks like the green hornblende of the granitic rocks of the region and is pleochroic in shades of yellowish to grayish green and olive. 
The accessory minerals sphene, zircon, apatite, allanite, and metallic opaque minerals are present in most specimens. Some grains are rounded and may be detrital.

\section{Quartzite (Quartz Sahist)}

At the south end of the Barrett Ridge basement exposure are three masses of quartzite (more correctly, quartz schist) whose relation to each other is unknown. The northernmost mass is a layer in the gneiss sequence. Most of the quartzite is light to medium gray, in part pinkish, and relatively dense. Layering, possibly original bedding, is shown by scattered spots and trains of $\mathrm{K}$-feldspar and sodic plagioclase and minor muscovite. This layering parallels a conspicuous shape orientation of the strongly sheared quartz grains, which are deeply and intricately sutured. Layering is also shown by variation in amount of metallic opaque minerals. Locally flakes of moderate-brown biotite and moderate-yellowgreen chlorite reflect layering. In one specimen, scattered needles and bundles of needles somewhat resemble sillimanite; this rock contains traces of muscovite and biotite, but no feldspar. Rounded, detrital zircon and epidote, and very locally garnet, are also present in the quartzite.

\section{Alaskite and Aplite}

Medium-grained alaskite is the predominant rock type of the felsic alaskite-aplite suite. Much less common is sugary aplite, which in part intrudes the alaskite. Pods and veins of simple quartz-feldspar pegmatite are also present and, in part, associated with vein quartz. Most of these rocks are light gray to pinkish gray and medium to fine grained and have a granitic texture. Locally, they are somewhat seriate, with pink $\mathrm{K}$-feldspar crystals as large as $5 \mathrm{~mm}$, but generally they are equigranular. The granitic texture is somewhat modified by granulation of some quartz and intricate mosaicking and suturing of most of the remaining quartz. This somewhat cataclastic overprint seems to be largely rehealed : there are no shear zones, and broken grains are not common. Scattered rounded quartz grains are found in some of the feldspar.

Plagioclase is generally sharply twinned and is in part zoned. Most seems to be oligoclase. The K-feldspar is in part grid twinned, and some is perthitic. The rock contains small amounts of grayish-yellow to moderatebrown biotite and traces of olive-brown biotite. The most common accessories are metallic opaque minerals and lesser amounts of zircon, apatite, and allanite.

Modes of five alaskites are given in table 11 and plotted in figure 14. Generally, K-feldspar is in excess of plagioclase, and quartz is abundant.
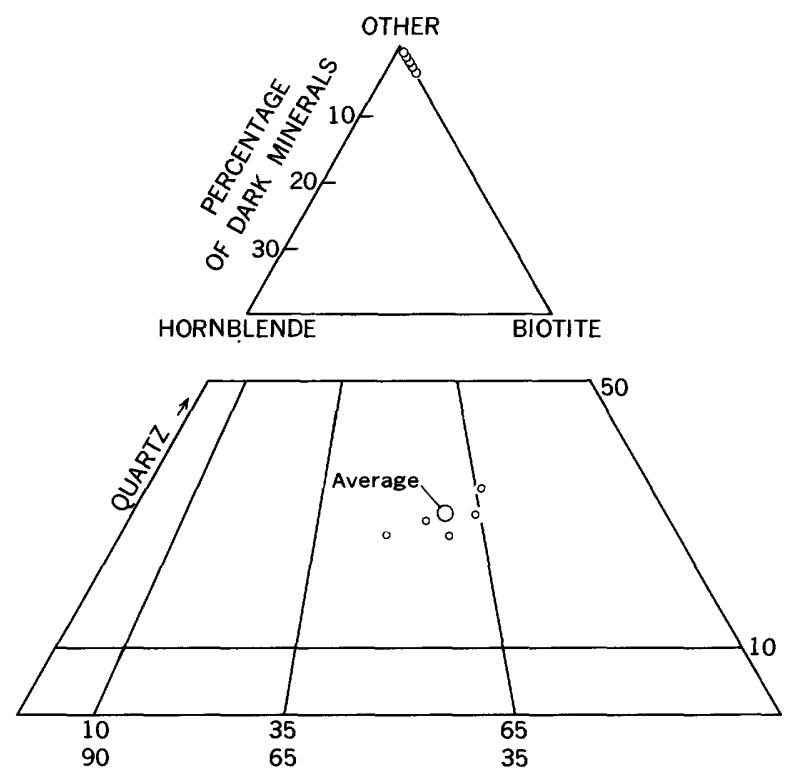

PLAGIOCLASE

K-FELDSPAR

FIgURe 14.-Modal plot of alaskite of Barrett Ridge.

TABLE 11.-Modes of alaskite of Barrett Ridge

[n.d.=not determined]

\begin{tabular}{|c|c|c|c|c|c|}
\hline No. & $\begin{array}{l}\text { Plagio- } \\
\text { clase }\end{array}$ & $\begin{array}{l}\text { K-feld- } \\
\text { spar }\end{array}$ & Quartz & Biotite & $\begin{array}{l}\text { Specific } \\
\text { gravity }\end{array}$ \\
\hline $\begin{array}{r}\mathrm{BM}-1 \mathrm{~A} \\
\mathrm{DR}-66-11 \ldots \\
66-24 \mathrm{~B} \\
66-38 \\
66-89 \mathrm{~B}\end{array}$ & $\begin{array}{l}37 \\
22 \\
24 \\
30 \\
32\end{array}$ & $\begin{array}{l}34 \\
43 \\
44 \\
42 \\
38\end{array}$ & $\begin{array}{l}27 \\
34 \\
29 \\
27 \\
29\end{array}$ & $\begin{array}{l}2 \\
1 \\
3 \\
2 \\
-\end{array}$ & $\begin{array}{l}2.63 \\
2.60 \\
2.61 \\
\text { n.d. } \\
2.61\end{array}$ \\
\hline Average & 29 & 40 & 29 & 2 & 2.61 \\
\hline
\end{tabular}

The large body of alaskite definitely intrudes the gneiss and quartzite sequence. Elsewhere in the gneiss sequence, dikes and sills of alaskitic rock (and other felsic types) are also common and are a few inches to a few feet thick. In additition to the definitely intrusive rocks, some alaskite, aplite, and pegmatite appear to have been sweated out of the gneiss. Strongly foliated gneiss grades almost imperceptibly into alaskitic rock, and ghost gneiss is seen in the alaskite. It is difficult, if not impossible, to assess how much of the alaskitic rock has been transformed essentially in place and how much has been intruded (and how far) from a genetically unrelated mass. The field evidence, however, suggests that much, if not all, of the alaskite and related rocks may have been sweated out of the relatively high grade granitic gneiss and that where enough material was mobilized, the masses moved relatively short distances.

\section{GABBROIC ROCKS OF LOGAN AND GOLD HILL}

Strikingly unusual gabbroic rocks are found along the San Andreas fault zone near Logan north of the Gabilan Range and at Gold Hill near Cholame (pl. 2). 
These rocks and their possible significance have been discussed by Ross (1970); so only a brief synopsis of those data will be presented here.

The outcrop at Gold Hill is a sliver in the San Andreas fault zone (Dickinson, 1966, p. 707). The outcrops at Logan probably are also part of a sliver in the fault zone, as they are significantly different from the basement rocks of nearby Salinian block outcrops. One of the most significant features of these gabbroic rocks is that they are unlike any other plutonic rocks of the Salinian block.

Two main rock types are present at Logan and also at Gold Hill. The most common one is hornblende quartz gabbro, which is composed of calcic plagioclase, darkgreen hornblende, and from 10 to 20 percent quartz. Only minor pyroxene or biotite is present. The other rock type is anorthositic gabbro composed of calcic plagioclase, rather pale-green amphibole, and clinopyroxene, which has a coarse-grained bizarre layered appearance that suggests a cumulate origin. Petrographically both of these rock types are extremely unusual. The physical similarity between the exposures at Logan and those at Gold Hill is very remarkable. Modal similarity of the quartz gabbros can be seen from figure 15 and tables 12 and 13 . The chemical similarity of the quartz gabbros is shown by the analyses given in table 30 .

The presence of both these unusual rock types in the San Andreas fault zone and their absence elsewhere in the Coast Ranges certainly suggest that they may be

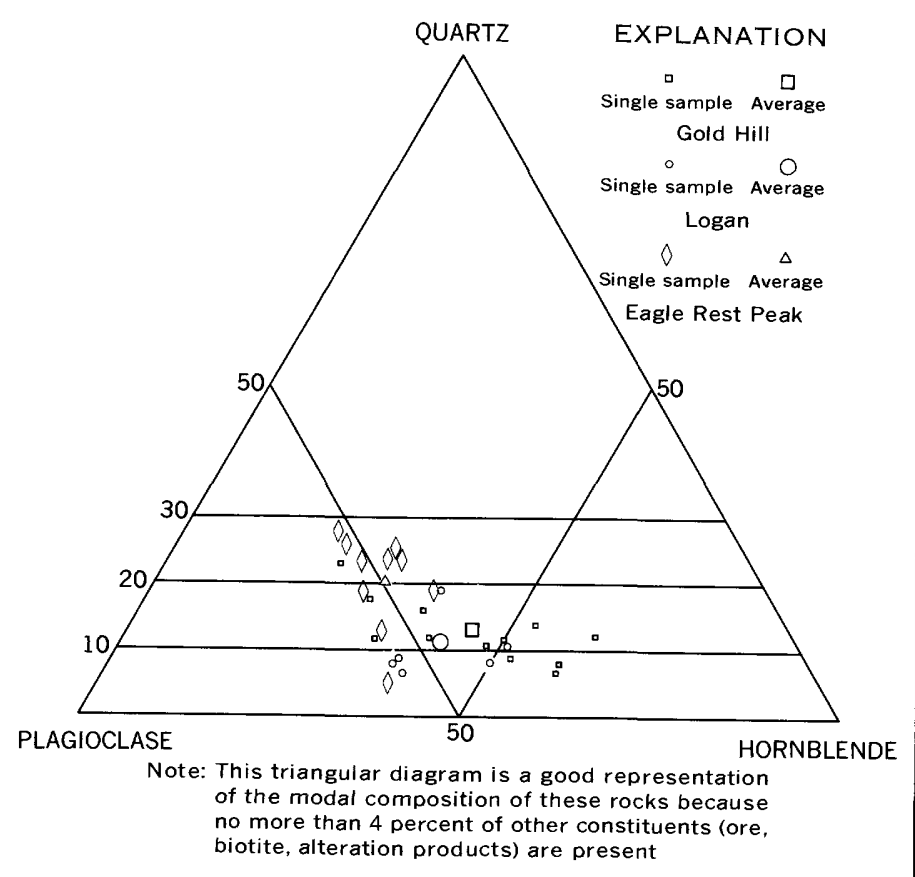

Figure 15.-Modal plot of hornblende quartz gabbro of Gold Hill, Logan, and Eagle Rest Peak areas.
TABLE 12.-Modes of hornblende quartz gabbro of Logan

[ $\mathrm{Ch}=$ chlorite, $\mathrm{Me}=$ metallic opaque minerals, $\mathbf{E}=$ epidote, Orp=orthopyroxene, $\mathrm{Clp}=$ clinopyrozene, $\mathbf{M u}=$ muscovite, $\mathbf{T r} .=$ trace, $\mathrm{n} . \mathrm{d} .=$ not determined

\begin{tabular}{|c|c|c|c|c|c|c|}
\hline No. & $\begin{array}{c}\text { Plagio- } \\
\text { clase } \\
\text { (An) }\end{array}$ & Quartz & Biotite & $\begin{array}{l}\text { Horn- } \\
\text { blende }\end{array}$ & Other & $\begin{array}{l}\text { Specific } \\
\text { gravity }\end{array}$ \\
\hline SJB-1 $\ldots$ & $37(72)$ & 10 & (?) & 48 & $\underset{(\mathrm{Me}) 1}{(\mathrm{Ch}) 4}$ & n.d. \\
\hline $\mathrm{DR}-\mathbf{5 8 8 \mathrm { A }}$ & $\begin{array}{l}52(72) \\
46(64)\end{array}$ & $\begin{array}{r}7 \\
12\end{array}$ & $\begin{array}{l}<1 \\
\text { Tr. }\end{array}$ & $\begin{array}{l}37 \\
34\end{array}$ & $\begin{array}{l}(\mathrm{Me}) 4 \\
(\mathrm{Me}) 2,(\mathrm{E}) 3 \\
(\mathrm{Ch}) 2\end{array}$ & $\begin{array}{l}\text { n.d. } \\
2.86\end{array}$ \\
\hline $\begin{array}{l}589 \mathrm{~A} \\
589 \mathrm{~B} \\
998\end{array}$ & $\begin{array}{l}42(70) \\
53(70) \\
41(75)\end{array}$ & $\begin{array}{r}19 \\
8 \\
8\end{array}$ & $\begin{array}{l}2 \\
2\end{array}$ & $\begin{array}{l}37 \\
35 \\
49\end{array}$ & $\begin{array}{l}\text { (Me)2 } \\
\text { (Orp)2, } \\
\text { (Clp)Tr. } \\
\text { (Me)<i }\end{array}$ & $\begin{array}{l}2.85 \\
2.81 \\
\text { n.d. }\end{array}$ \\
\hline A verage....... & 45 & 11 & 1 & 40 & 3 & $\ldots$ \\
\hline DR-589-1 (aplite) .. & $5 \overline{6}$ & 34 & & & $\begin{array}{l}\text { (Mu) 4, } \\
\text { (Ch)4, } \\
\text { (E)2 }\end{array}$ & 2.69 \\
\hline
\end{tabular}

TABLE 13.-Modes of hornblende quartz gabbro of Gold Hill

[Samples DR-1061 to 1065-2 are fragments from Cenozoic (?) deposits near Gold Hilli; $\mathrm{Me}=$ metallic opaque minerals, $\mathrm{Alt}=$ alteration minerals, n.d. $=$ not determined, Tr. $=$ trace]

\begin{tabular}{|c|c|c|c|c|c|c|}
\hline No. & $\begin{array}{l}\text { Plagio- } \\
\text { clase } \\
\text { (An) }\end{array}$ & Quartz & Biotite & $\begin{array}{l}\text { Horn- } \\
\text { blende }\end{array}$ & Other & $\begin{array}{l}\text { Speciffc } \\
\text { gravity }\end{array}$ \\
\hline
\end{tabular}

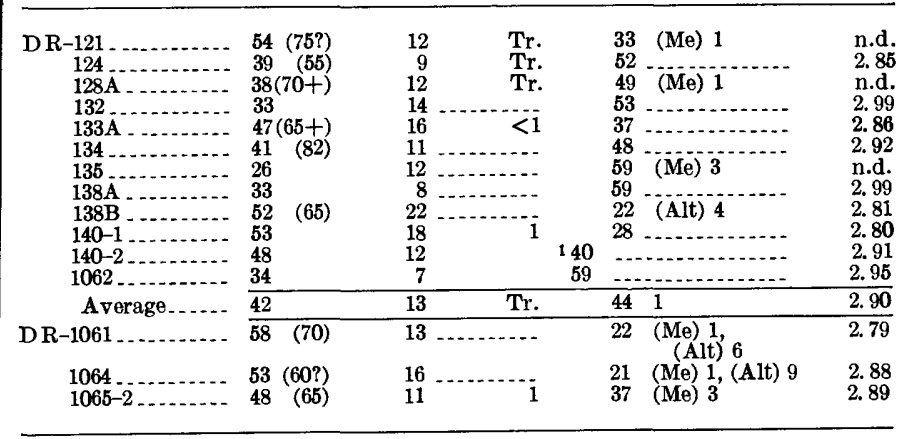

1 Abundant alteration products.

correlative. The Gold Hill and Logan outcrops are now 100 miles apart. This separation of what may have once been one gabbroic mass is possibly due to lateral movement on the San Andreas fault zone. If both gabbroic areas are rootless slivers in the fault zone, their separation is a minimum displacement.

The original site of intrusion of these gabbro slivers is not known. No rocks like them are known from the Salinian block of the Coast Ranges, although they somewhat resemble the quartz gabbro and anorthositic gabbro which form the westernmost basement outcrops of the San Emigdio Mountains, in the Eagle Rest Peak area (pl. 2). Possibly the Gold Hill and Logan rocks have been sliced off this body in the San Emigdio Mountains.

These gabbros may be slivers of ophiolitic oceanic crust. Quartz gabbro and coarse-grained gabbros with exotic textures are being found in increasing amounts in terranes of mafic and ultramafic rocks in the Coast Ranges. Bailey, Blake, and Jones (1970) interpreted these mafic and ultramafic sequences as oceanic crust. This interpretation raises the possibility that the Gold 
Hill and Logan gabbro may have "leaked up" along the San Andreas fault zone from underlying oceanic basement. Nevertheless, the presence in the San Andreas fault zone of the two very distinctive and unusual rock types at Gold Hill and Logan seems to be good evidence that the two may have been parts of one body, even if there is an underlying basement of oceanic mafic and ultramafic rocks in the region.

\section{BASEMENT ROCKS OF THE SANTA LUCIA RANGE}

The basement rocks of the Santa Lucia Range west of Salinas Valley have not been examined in this study, yet they are a vital part of any discussion of the basement rocks of the Coast Ranges. For this reason a short summary of the metamorphic and granitic rocks is presented here; this summary is based largely on the work of Compton $(1960,1966)$. The area of exposed basement rocks in the Santa Lucia Range is estimated from the Santa Cruz sheet of the geologic map of California (Jennings and Strand, 1959) to be about 400 square miles of metamorphic rocks and slightly more than 200 square miles of granitic rocks. These figures are only crudely approximate, but they do convey the picture that metamorphic rocks dominate the Santa Lucia basement; in most other Coast Ranges basement areas, granitic rocks are dominant.

Compton (1966, p. 278-284) stated that the metamorphic rocks are mainly biotite-feldspar quartzite and quartzo-feldspathic gneiss and granofels with many associated layers of calc-hornfels, amphibolite, aluminous schist, and calcite and dolomite marble. He further stated that the general association suggests metamorphosed platform-type sediments and that the bulk composition of impure quartzite and quartzo-feldspathic gneiss suggests a granitic source for the bulk of these sediments.

The Santa Lucia granitic rocks range in composition from peridotite to granite and in form from nebulous spots, veins, and dikes to discrete large masses (Compton, 1966, p. 281). There are virtually no published modal data on these granitic rocks and only sparse chemical data. In addition, most published descriptions of these rocks (Fiedler, 1944; Trask, 1926; Compton, $1960,1966)$ give little information about proportions of the various rock types. A more recent report by Wiebe (1970), however, does describe and show a map of the distribution of the granitic and gabbroic rocks of a 100square-mile area in the northern part of the Santa Lucia Range. If a generalization can be made at this stage, it is that quartz diorite and granodiorite are dominant and that quartz monzonite is less common but present in significant amounts, particularly at the north end of the range. I feel that the tendency to lump all granitic rocks under the classic name of "Santa Lucia quartz diorite," particularly in the older reports, tended to underplay the range of composition and the significance and abundance of felsic, potassic granitic rocks in the Santa Lucia block. But until more modal and chemical data become available, we cannot make any meaningful quantitative statements about the composition of the Santa Lucia granitic basement.

\section{PETROGRAPHIC AND STRUCTURAL SUMMARY OF THE GRANITIC BASEMENT IN THE COAST RANGES}

\section{GENTRAL COAST RANGES}

The granitic rocks of the central Coast Ranges (fig. 1), which are largely of quartz diorite-granodiorite composition, have an overall similarity that suggests they are comagmatic and may well be part of one intrusive mass. Probably the most obvious comparative feature of these rocks is the coarse irregular habit of the dark minerals. In particular, large books of biotite seem to characterize these masses. Also, these rocks are relatively rich in quartz, even where no $\mathbf{K}$-feldspar is present. Spotts (1962) sampled and studied zircon and other accessory minerals from the granitic masses of the central Coast Ranges. He concluded that the general similarity in heavy-mineral assemblages indicates a similar magmatic source and is evidence that these isolated masses came from closely related magmas. Spotts emphasized that these data alone are not conclusive but do support an origin from similar magmas.

Two significant variations from the quartz diorite type are present. At Ben Lomond a garnet-bearing alaskite is a separate intrusive whose relation to the quartz diorite is unclear. At Point Reyes, rocks in the Mount Wittenberg area range from quartz diorite to quartz monzonite, but it is not known whether this is a separate intrusion or a gradation from rocks with more calcic plagioclase. In addition to these two rather well defined variants, there are other local gradations to quartz monzonite. Field evidence shows that some of the felsic variance is in separate, presumably later intrusions, and the presence of alaskite, aplite, and simple pegmatite also indicates late alkali-rich material. Also, variation in late $\mathrm{K}$-feldspar concentration produces local alkali-rich patches. It should be emphasized, therefore, that although the outcrop is dominantly quartz diorite-granodiorite, there are significant variations to more felsic rocks.

The modal field in figure $3 B$ can be divided into two fields: one of the quartz diorite type and one largely of the alaskitic rocks of Ben Lomond and the more felsic rocks of Point Reyes. It is tempting to postulate these as two separate intrusive types. However, the gap in 
figure $3 B$ may be due to insufficient samples, and the known local variation in the quartz diorite suite also makes this a dubious conclusion.

A reasonable conclusion is that for about 125 miles along the Salinian block from Bodega Head to Ben Lomond there is a comagmatic suite of rocks; in other words, this area is underlain by a relatively coherent block of basement rocks.

\section{SOUTHERN COAST RANGES}

The division of the basement rocks of the southern Coast Ranges (fig. 1) from those of the central Coast Ranges is not intended to imply a geologic boundary. In fact, the northernmost rocks of the Gabilan Range are similar to the quartz diorite of Ben Lomond. The granitic rocks of the central Coast Ranges are a relatively well-defined, presumably closely related unit, whereas those of the southern Coast Ranges are more varied and can more conveniently be discussed separately.

The largest basement mass in the Coast Ranges, excluding the Santa Lucia Range, is the Gabilan Range. This range covers about 350 square miles and consists largely of granitic rocks and lesser amounts of metamorphic rocks. The southern two-thirds of the range is mostly underlain by a variable group of rocks ranging from quartz diorite to quartz monzonite that I refer to as the granodiorite of the Gloria-Bickmore Road. Near the mouths of Stonewall and Bryant Canyons (pl. 2) gneissic variants seem to be related to nearby metamorphic rocks. The Gloria-Bickmore mass, in particular, presents the problem of how to map variable granitic masses in an area of scattered exposures. How much variability can there be in a single granitic mass? Here, the answer seems to be, a great deal.

One of the Gloria-Bickmore variants is a relatively felsic rock, peppered with biotite and containing scattered poikilitic potassium feldspar phenocrysts. This type seems more common near the south end of the Gabilan Range. Also, it is physically and modally very similar to the granitic rock of the La Panza Range. The La Panza rocks are notably homogeneous. Although these rocks have a fair modal range (fig. 12), they are remarkably similar over an outcrop area of about 100 square miles. Unfortunately, there is very little basement outcrop in the 50-mile gap between the La Panza Range and the southern part of the Gabilan Range. The many wells that have bottomed in basement rocks show that there is granitic rock between the two ranges, but its petrographic character is as yet unkown to me. The small Adelaida granitic mass north of Paso Robles is similar to the La Panza rock, as is the rock along the west side of the San Andreas fault in the area of Stock- dale Mountain. These rocks could all be part of one intrusive mass or possibly closely related intrusives from a similar magma. It does seem that there is possibly a large coherent block in the Salinian block that stretches from the southern Gabilan Range to San Juan Creek, a distance of about 125 miles.

The dominant rock type in the northern part of the Gabilan Range is the coarse-grained biotite quartz monzonite of Fremont Peak. This is a relatively nondescript "low-melting trough" rock that is composed of about equal parts of $\mathbf{K}$-feldspar, sodic plagioclase, and quartz. No intrusive relation with the Gloria-Bickmore has been seen. There is a general resemblance to the alaskite in the Ben Lomond area, but the Ben Lomond mass has rather abundant accessory pink garnet, whereas I have not seen garnet in the Fremont Peak mass. Other felsic quartz monzonites in the Gabilan Range (fig. $9 D$ ) are similarly undiagnostic.

East of the La Panza Range and butting against the east side of the Chimeneas-San Juan-Red Hills fault zone are the gneissic basement rocks of Red Hills and Barrett Ridge. Several square miles of quartzofeldspathic gneiss, associated with lesser amounts of biotite-rich gneiss, biotite and hornblende schist, and quartzite, makes up the Barrett Ridge outcrops. Quartz diorite gneiss, augen gneiss, biotite gneiss, amphibolite, and minor amounts of marble make up the Red Hills outcrops. The gradation of the gneiss of Red Hills to homogeneous granitic rock suggests ultrametamorphism or granitization of a gneissic terrane. The presence of all stages from sharply layered gneiss through patchy banding to homogeneous rocks that contain ghost gneiss patches with grossly parallel foliation suggests strongly that these rocks are part of a highly metamorphosed dominantly sedimentary sequence, rather than a primary gneissic intrusive sequence. Thus, it appears from these meager outcrops that the Chimeneas-San JuanRed Hills fault zone may separate the granitic terrane of the La Panza Range area from a much different basement to the east represented by the Barrett Ridge and Red Hills rocks. Also, this fault zone might be a branch of the San Andreas system. The ChimeneasSan Juan-Red Hills fault zone appears to have a strikeslip component, as suggested by fault horses of marble strung out like beads along a 3-mile segment of the fault in the Barrett Ridge area. The fault north of Red Hills almost surely merges with the San Andreas fault zone, but south of the Barrett Ridge its extent is not clear. Possibly it could curve back toward the San Andreas fault zone through Cuyama Valley. Thus we can speculate that a large fault lozenge may be present here in the San Andreas system that is about the same 
size as the block between the San Gabriel and San Andreas faults.

On the other hand, the Chimeneas-San Juan-Red Hills fault may continue southeastward, parallel to the Barrett Ridge trend, and intersect the Big Pine fault. If it does, the Mount Abel-Mount Pinos rocks would be in this block. These rocks are typified by homogenized gneiss and are unlike the basement rocks north across the San Andreas fault and east across Big Pine fault (pl. 3).

In addition to the outcrops in the southern Coast Ranges that have already been discussed, basement slivers in the San Andreas fault zone crop out. The exposures of hornblende quartz gabbro and anorthositic gabbro at Logan and Gold Hill are unlike any known outcrops in the Salinian block. Also, the rocks exposed in the fault zone at the Taylor and Varian Ranches (pl. 2) are unlike most of the rocks of the Gabilan and La Panza Ranges. These rocks somewhat resemble rocks of the central Coast Ranges, and coarse irregular dark minerals, K-feldspar in minor amounts as stringers and lacy patches, a locally prominent primary foliation, and the general appearance are reminiscent of some rocks of Bodega Head and the Farallon Islands. In general, the quartz content is a bit lower in the Taylor and Varian rocks, but not significantly so.

\section{REGIONAL CONSIDERATIONS}

The Coast Ranges granitic basement has a rather special and unusual setting - a long, thin belt bounded on the east by the San Andreas fault zone and on the west by the Sur-Nacimiento fault zone. The basement on both sides of this belt is devoid of granitic rocks. This setting has raised the question of whether this block reached its present position as a relatively coherent unit along faults or whether the granitic basement outcrop areas are more or less unrelated blocks that owe their present distribution to iceberglike rafting in a sea of Franciscan rocks, which in turn were moved as a unit along faults to the present configuration.

This petrographic reconnaissance suggests that the Coast Ranges granitic basement of the Salinian block (fig. 16) is a closely related group of rocks and not a heterogeneous and rather random gathering of a wide variety of basement types. The bulk of the granitic rocks from Bodega Head to Ben Lomond are very probably comagmatic and may well be part of one variable intrusive mass. Likewise, the rocks in the southern part of the Gabilan Range and the La Panza Range are very similar. There is even a suggestion that the northernmost rocks in the Gabilan Range are similar to the Ben Lomond rocks, a correlation which would provide a tie between the two major segments of the Salinian block. The rocks east of the Chimeneas-San Juan-Red Hills fault and the Mount Abel-Mount Pinos basement, which are typified by gneissic rocks, are an exception to this coherent picture; they may be a large fault segment of unknown relation to the rest of the Salinian block-that is, a large fault lozenge in the San Andreas fault system. Another anomaly in this block is the presence of the gabbroic rocks of Logan and Gold Hill, which have no exposed counterparts in the Salinian block, but which are most likely fault slivers in the San Andreas fault zone. Nevertheless, the rather simple general pattern of the granitic rock distribution in the Salinian block suggests the granitic rocks form a relatively coherent basement block.

A possibly significant petrographic characteristic of the Coast Ranges rocks is the rarity, and even in part the complete absence, of metallic opaque minerals in rocks with abundant dark minerals. This characteristic, stressed in the individual unit descriptions, is widespread enough to be considered a regional characteristic of the Coast Ranges granitic rocks. Spotts' data (1962, tables 3-5) confirm the indications from the petrographic study of thin sections that metallic opaque minerals are rare in these central Coast Ranges masses. Absence and rarity of sphene are also notable in some areas in rocks that have abundant dark minerals.

In conclusion, it should again be stressed that the granitic rocks of the Coast Ranges (Salinian block) range from quartz monzonite to quartz diorite (fig. 3) and that quartz content is much the same throughout this compositional range. Also, in the 450 square miles of granitic rock outcrop sampled (fig. 1), quartz monzonite and granodiorite are about equally abundant, and quartz diorite is somewhat less abundant (fig. 2).

These conclusions have not taken into account the largest area of basement rocks in the Salinian block, the Santa Lucia Range granitic and metamorphic rocks. This complex area of highly metamorphosed quartzofeldspathic gneiss, quartzite, amphibolite, schist, and marble intermixed with a wide variety of granitic rocks has most recently been studied in part by Compton (1966, p. 278) and Wiebe (1970), but was examined only very cursorily by me in the present study. There may be fundamental differences between the basement terrane of the Santa Lucia Range and the rest of the Salinian block. The abundance of quartzo-feldspathic gneiss and the migmatitic mixing of metamorphic and granitic material, as well as the presence of some granulitegrade metamorphism and locally abundant garnet in both the metamorphic and granitic rocks, are in marked contrast to the dominantly granitic terrane in the 
AND GNEISSIC ROCKS, SAN ANDREAIS FAULT, CALIF.

Gabilan Range and to its discrete roof-pendantlike metamorphic bodies.

A major structural break may be present between these two basement terranes along the Salinas Valley. The Reliz, Espinosa, San Marcos, and Rinconada faults (Jennings and Strand, 1959; Jennings, 1959; pl. 2) make a prominent fault zone that diverges from the
Nacimiento fault zone (fig. 16). This possible major structural break and the marked contrast of the granitic rocks of the La Panza and Gabilan Ranges with the metamorphic and migmatitic basement of the Santa Lucia Range strongly suggest a basement slice between the Sur-Nacimiento fault zone and the diverging fault zone to the east (fig. 16).

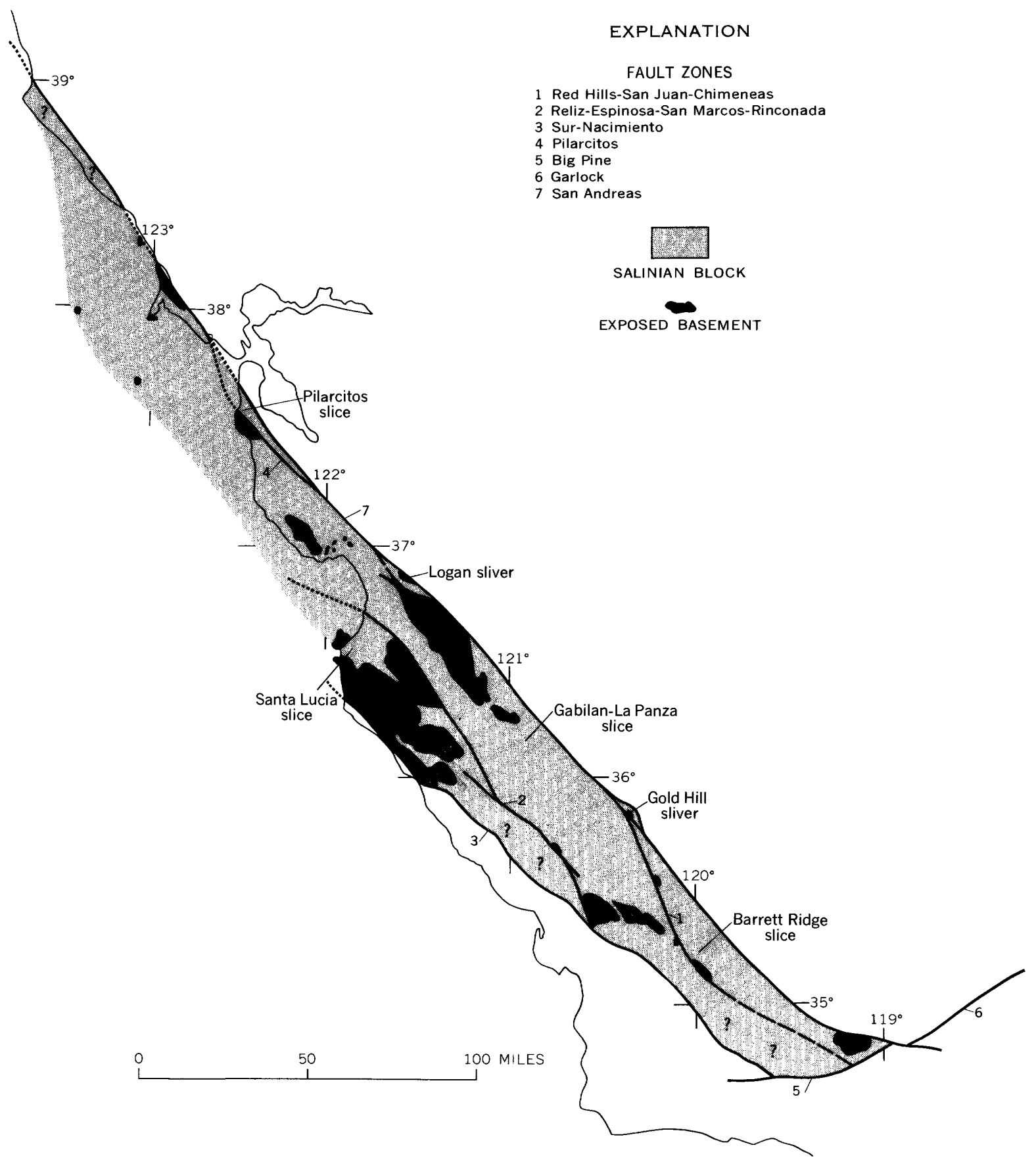

Figure 16.-Possible basement slices in the Salinian block. 


\section{IMPLICATIONS ON THE ORIGIN OF THE SALINIAN BLOCK}

The preceding discussion identifies a central core slice of dominantly granitic rock bounded by slices that contain abundant gneissic rocks (fig. 16). These three slices in combination make up the Salinian block, whose granitic basement, completely devoid of Franciscan and ultramafic rocks, is in contact on both sides with Franciscan terrane that lacks associated granitic rocks. The origin of this block, sandwiched between the San Andreas and Nacimiento-Sur fault zones, has long been an enigma.

Perhaps the quartz diorite line should be mentioned at this point. Moore (1959) compiled a considerable amount of data on the distribution of granitic rock types in the western United States in an attempt to evaluate suggestions made as early as 1915 by Lindgren that the granitic rocks "became more acidie" eastward from the continental margin. Moore's compilation map $(1959$, p. 199), based on very limited data in the Coast Ranges, shows the rocks of the entire region to be dominantly quartz diorite. The moderate amount of modal data that I have collected (fig. 3) suggests otherwise. Yeats (1968) attempted to revise Moore's line in the Coast Ranges largely on the basis of the generalized descriptions by Compton (1966). Yeats' revised quartz diorite line in the Coast Ranges (1968, p. 311-312) was drawn between Bodega Head and Point Reyes, a line which does not seem likely from the data I have. He also drew the quartz diorite line between the Gabilan and Santa Lucia Ranges and thus left the very significant mass of felsic quartz monzonite of the Monterey Peninsula on the "wrong" side of the line. The data presented in this report suggest that the whole Salinian block may well be on the "wrong" side of the quartz diorite line in its present position, for the Salinian block appears to be an anomaly in the regional picture Moore (1959) described. One possible reason for this anomalous position might be large-scale displacement of the block from its original site of intrusion by movement of the San Andreas fault zone.

Cumulative evidence from many sources leaves little doubt that the San Andreas fault zone is a fundamental and rather simple break between granitic and Franciscan basement in the Coast Ranges; in other words, the east boundary of the Salinian block is relatively well defined. The west boundary of the Salinian block appears to be more complex. The Nacimiento and Sur faults are commonly connected on small-scale compilations to create an oversimplified fault boundary parallel to the east margin of the Salinian block, as shown in figure 16. Plate 2 shows that at larger scales there is no master break. Loney (1970) pointed out that local complications along what has traditionally been called the Nacimiento fault zone indicate the need for more detailed work to delineate the fault zone and clarify relations along it. Studies along other parts of this zone have also brought out conflicts and uncertainties about direction and magnitude of movement. (See Vedder and Brown, 1968, p. 242.) Page (1970) also pointed out the complications along this zone and emphasized the importance of the Sur-Nacimiento fault zone in continental margin tectonics.

A belief has been built up that the Salinian block has almost miraculously appeared in the midst of the dominantly Franciscan basement of the Coast Ranges. The Franciscan west of the Nacimiento-Sur and east of the San Andreas faults by this thesis is assumed to be more or less in place and the intervening Salinian granitic rocks are assumed to be exotic. Gastil (1968, p. 208-210) suggested that large-scale right-lateral movement on the San Andreas fault zone to emplace the Salinian block also required equal and opposite left-lateral movement on the Nacimiento zone.

The thesis of sea-floor spreading postulates the piling up of trench material, the Franciscan, against the continental margin as the conveyer belt of oceanic crust impinges on the continent. The Sur-Nacimiento fault zone may well be an ancient continental-oceanic interface as Page (1969, p. 51) suggested; such a tectonic relationship would explain why contorted Franciscan of the coastal belt butts against the Salinian granitic basement. Gastil $(1968$, p. 210) was concerned because the Coast Ranges do not have an intermediate belt of batholithic rocks that intrude eugeosynclinal rocks to separate Franciscan rocks from a belt of batholithic rocks that intrude miogeosynclinal rocks, a relationship he notes is the general case in California east of the San Andreas fault and in the Peninsular Ranges. If we accept the conveyer-belt mechanism of sea-floor spreading, however, the absence of such an intermediate belt can be explained by the impinging oceanic crust and its crushed-up rider, the Franciscan trench deposits, grinding and eating their way into and through the eugeosynclinal belt and into the miogeosynclinal belt. The eugeosynclinal rocks were carried down the oceancontinental interface below the continent, leaving the present configuration of Franciscan butting against the Salinian block (Page, 1969, p. 51). This means that the Sur-Nacimiento zone is no less a fundamental break than the San Andreas; however, because of its different origin, one would expect it to be irregular and characterized by contortions. The physical emplacement of the Salinian block and the Franciscan terrane west of 
the Salinian block could most easily be accounted for by lateral movement on the San Andreas fault zone. Such movement would readily explain why the present configuration of the Salinian granitic belt and the Franciscan coastal belt essentially duplicates rock relations that exist from the Klamath Mountains south to the Peninsular Ranges.

\section{BASEMENT ROCKS OF THE TRANSVERSE RANGES}

To provide a sample of the basement rocks, the major granitic and gneissic units along the San Andreas fault from the Cajon Pass area west to the Mount Abel area were examined and sampled for petrographic and chemical study. As shown on plate 2, the units studied include, from east to west, (1) the gneissic and granitic complex of Cedar Springs, (2) the gneiss of Wrightwood, (3) the granodiorite of Holcomb Ridge and the presumably related rocks of the Largo Vista area, (4) the gneiss of Pinyon Ridge, (5) the granodiorite of Fairmont Reservoir and the presumably related rocks of Burnt Peak, (6) the gneiss of Bouquet Reservoir, (7) the gneissic and granitic complex of Liebre Mountain, (8) the granodiorite of Lebec and the related rocks of Brush Mountain, (9) the porphyroblastic gneiss of Frazier Mountain, and (10) the homogenized gneiss of the Mount Abel-Mount Pinos area. Other smaller basement masses will be described very briefly.

A composite plot (fig. 17 A) of more than 230 modes of Transverse Ranges specimens makes a fairly well defined field that shows the generally quartz-rich nature of the suite. Granodiorite is the dominant rock type. To see if there was any significant difference in the basement on opposite sides of the San Andreas fault,

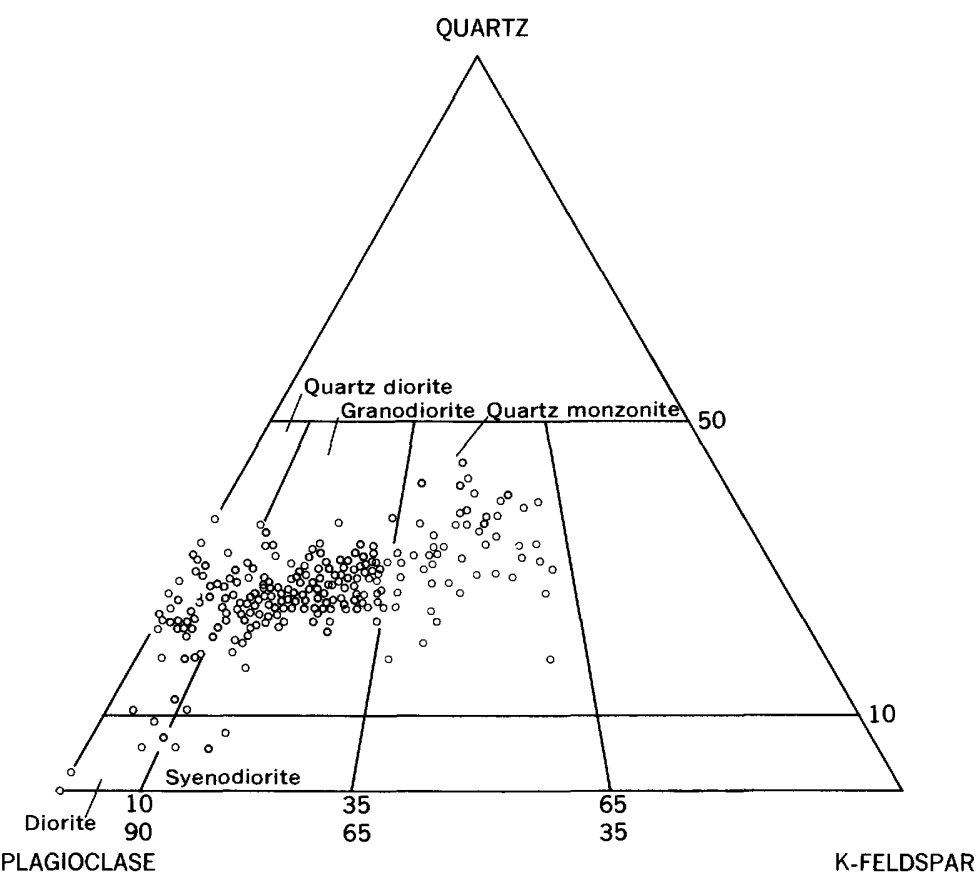

$A$. COMPOSITE OF MODES OF TRANSVERSE RANGES

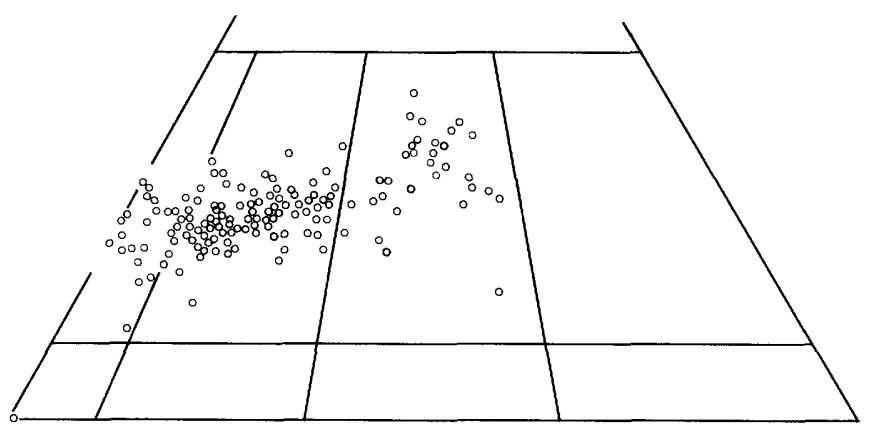

$B$. COMPOSITE OF MODES NORTH OF SAN ANDREAS FAULT

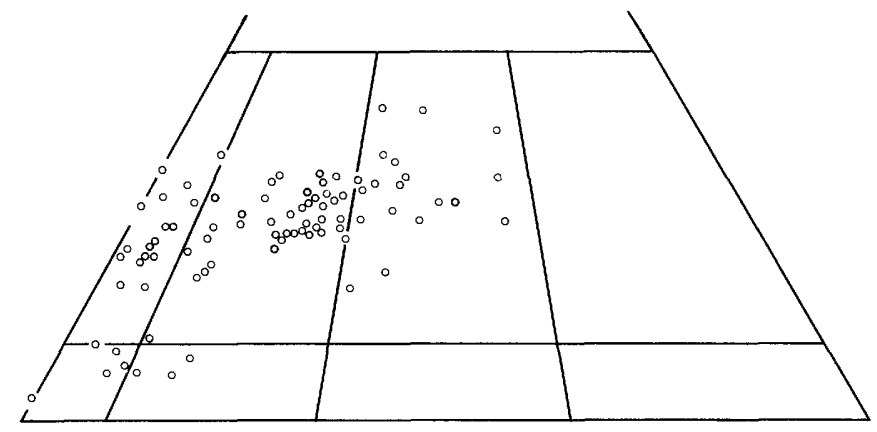

C. COMPOSITE OF MODES SOUTH OF SAN ANDREAS FAULT

Figure 17.-Composite of modal plots of granitic rocks in the Transverse Ranges. 
specimens north and south of the fault were plotted separately (figs. $17 B, C$ ). These two plots have trends that are virtually identical with the trend in the composite plot. These similarities in trend may or may not be significant, because if large numbers of quartz-bearing granitic rocks from different areas are compared, their average compositional trends will probably be essentially the same. I do think, however, that these data do not support the rather prevalent thought that the San Andreas fault juxtaposes significantly different basement rocks in the Transverse Ranges. This by no means precludes large lateral movements along this zone, because a large gneissic shield area, of which the Transverse Ranges are probably a part, could undergo considerable movement and still juxtapose similar gneissic and granitic rocks. In other words, the present gross distribution of granitic and gneissic basement along both sides of the San Andreas fault in the Transverse Ranges cannot be used by itself as evidence for or against large lateral movement along this fault zone.

\section{BIOTITE GRANODIORITE OF CEDAR SPRINGS}

\section{SETTING AND GENERAL DESCRIPTION}

The northern slope of the San Bernardino Mountains westward from the Cedar Springs area to the Cajon Pass area is underlain by a medium-dark-gray mediumgrained biotite granodiorite that is mostly seriate to porphyritic and has a remarkably uniform texture over the examined outcrop area of some 25 square miles. Similar rocks presumably extend south and east of Cedar Springs (Dibblee, 1967), but I have not examined them. The homogeneity of the specimens shown in figure 18 and table 14 is somewhat misleading, as there is considerable admixture of gneissic rocks with the granodiorite, particularly in the Cedar Springs area. In part, the granodiorite appears to intrude the gneiss, but more commonly the intergradation of the two suggests that the granodiorite may be the homogenized end product of ultrametamorphism in a high-grade metamorphic terrane. The granodiorite of Cedar Springs appears to be intrusive into the gneiss of the Wrightwood area at its western outcrop limit, near Cajon Pass.

The seriate to porphyritic parts of this mass have pink- to salmon-colored $\mathrm{K}$-feldspar crystals that are as long as $50 \mathrm{~mm}$ but that in general do not exceed 15 $\mathrm{mm}$. Associated with this rock type are abundant dikes and masses of coarse pegmatite that have K-feldspar of the same color as that in the seriate parts of the granodiorite.

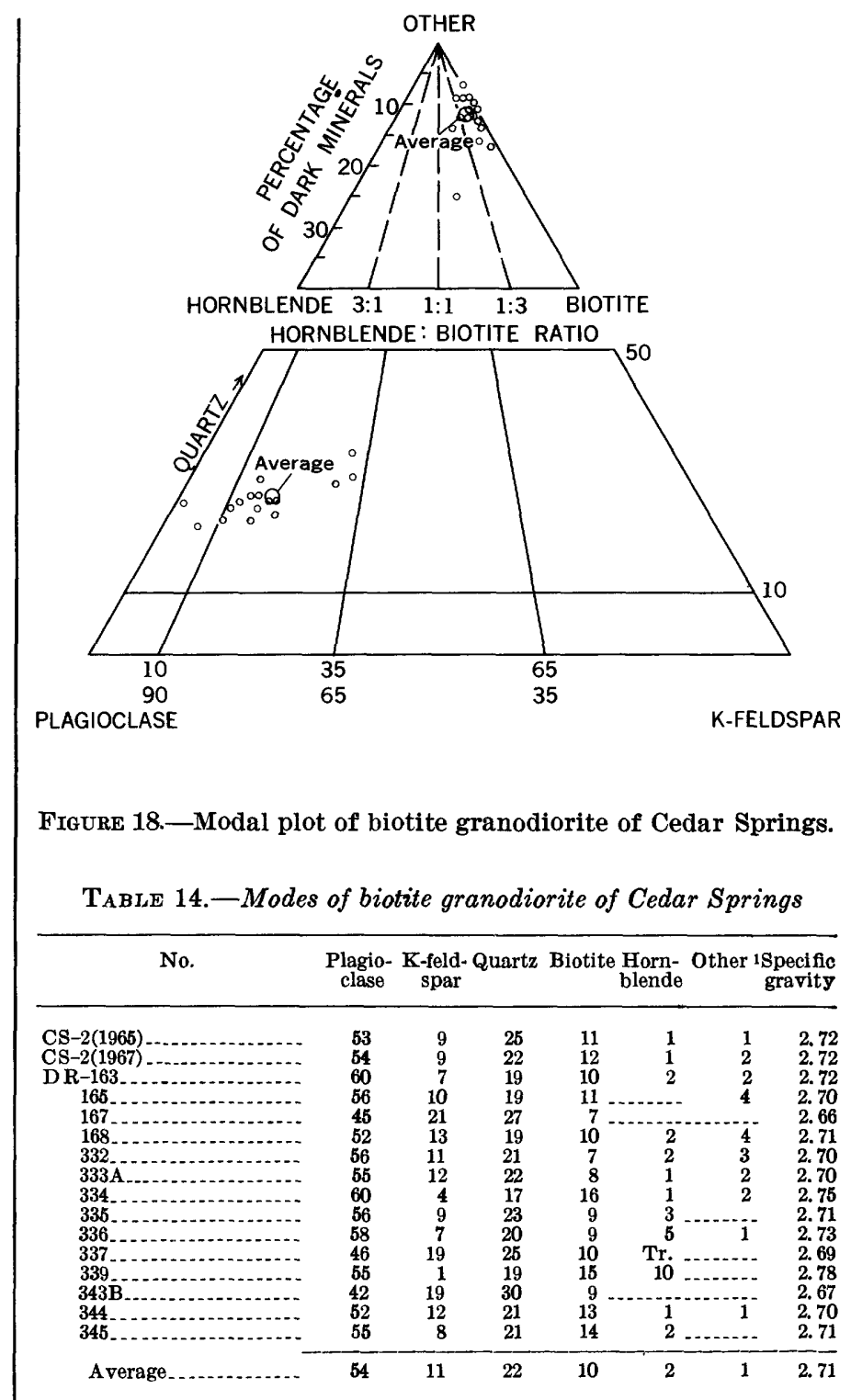

1 Mostly sphene and metallic opaque minerals.

\section{MICROSCOPIC DESCRIPTION}

The texture of this rock ranges from hypautomorphic to xenomorphic and from equigranular through seriate to porphyritic. That most of these rocks have undergone considerable strain is indicated by mosaicked and sutured quartz, which is locally granulated, and bent plagioclase and biotite crystals. Also, locally, quartz is deformed into slivers in constrictions between feldspar crystals.

The most abundant mineral, plagioclase, is generally sodic andesine. It is cleanly twinned and oscillatorily zoned. The only alteration is minor dusting of sericite; most plagioclase is notably fresh. The $\mathrm{K}$-feldspar is 
late and has inclusions of all the other major rock constitutents. Although partly interstitial, the K-feldspar is more commonly present as "poikilitic phenocrysts." It exemplifies one of the few coarse-grained granitic rocks that $I$ have seen that is truly porphyritic (bimodal) and not seriate (gradational), but these rocks grade to seriate and equigranular types, all with a remarkably similar groundmass.

The dark minerals, biotite and hornblende, range from well-formed crystals to shredded aggregates. Alteration is minor: biotite is in part altered to chlorite (probably penninite), which has stringers and blebs of sphene in it; very little hornblende is altered, but epidote and calcite alteration products are seen in some crystals. Pleochroism of the biotite is $\mathrm{X}=$ grayish yellow to grayish orange and $Z=$ dark yellowish brown. Pleochroism of the hornblende is $\mathrm{X}=$ moderate greenish yellow, $\mathrm{Y}=$ light olive, and $\mathrm{Z}=$ dark yellowish green.

Sphene is the most common accessory mineral, making up 2-3 percent of some specimens. It occurs commonly as euhedral crystals that are peppered with metallic opaque inclusions that form patterns reminiscent of Arabic characters. Some specimens have as much as 2 percent metallic opaque minerals, dominantly magnetite, but most specimens contain less than 1 percent. Apatite and zircon are ever present; allanite is found in some specimens. Zircon is abundant in some specimens.

\section{DISTINGUISHING FEATURES}

The general texture of this rock in outcrop is distinctive in this region. The rather homogeneous granitic texture over an extensive area, though gneissic rocks are mixed throughout the mass, is also distinctive. In some places, the $\mathrm{K}$-feldspar is concentrated solely in phenocrysts; its absence from the groundmass is noteworthy. Scattered, rare phenocrysts as long as $50 \mathrm{~mm}$ accentuate this texture. The virtual absence of dioritic inclusions in a granitic rock of this composition is diffcult to explain, but it helps to identify this body. The peppering of sphene crystals with grains of metallic opaque minerals and a more than average amount of zircon in some specimens may also be distinctive.

\section{BASEMENT ROCKS OF THE WRIGHTWOOD-HOLCOMB AREA}

The granodiorite of Holcomb Ridge, part of which was previously called the Holcomb Quartz Monzonite by Noble (1954), and the gneiss of the Wrightwood area crop out in a narrow belt about 45 miles long, on the north side of the San Andreas fault from near Cajon Pass west to the vicinity of Palmdale. Though the two units have been mapped separately (Dibblee, 1967, pl. 1), they have much in common.

Both the granodiorite and the gneiss have grossly parallel foliation that trends northwest and dips steeply, generally to the northeast. Both units also have northwest-trending marble layers. In addition, where the "contact" between the two units is relatively well exposed, in the Largo Vista area, it is mixed and gradational, and the granodiorite to the west bears many gneissic zones that resemble the gneiss of the Wrightwood area. Also, the two units have the same general composition range and the same mineralogy.

Thus, there is much to suggest a close genetic relation between the gneiss and the granodiorite. The belt of marble along Holcomb Ridge, the abundant foliation and gneissic zones in the granodiorite parallel to the gneiss, and the fuzzy contact all suggest that the granodiorite is a homogenized or granitized variant of the high-grade gneiss of the Wrightwood area. Although the outcrop belt becomes narrower and exposures are much poorer to the west, the granodiorite may become more homogeneous and less gneissic and foliated in that direction.

This simplified picture is complicated, in the Largo Vista area, by the granitic rocks and felsic gneiss, which are generally more felsic than either the granodiorite of Holcomb Ridge or the gneiss of Wrightwood, yet are considered gradational with both those types. In figure 19 the felsic Largo Vista rocks have been plotted with a distinguishing symbol. Rocks similar to the Holcomb, Wrightwood, and Largo Vista types are also found farther east, at Mescal Creek. Though there is considerable spread in the modal field when all these rocks are plotted together (fig. 19), they may well be one related suite. Certainly there has been mobilization and intrusion, but its magnitude is not known. Some felsic and coarse-grained layers in the gneissic sequence are similar to rocks from areas of massive granitic rock that appear to be intrusive.

The rock types in this suite seem to have a gross, beltlike distribution. East of the most prominent zone of marble in the gneiss of Wrightwood, marble seems particularly abundant, and coarse distinctive phlogopite is common in the carbonate layers. The belt of rocks cutting through the Largo Vista area is more felsic, and the belt of Holcomb rocks farther west is more 
mafic and also seems to have more marble. Perhaps the three belts could be defined as formations with more detailed mapping. The rock distribution and the gross structure, as noted by Dibblee (1967), suggest a homoclinal sequence, but a simple sequence seems rather unlikely in this structurally complex region. The Holcomb fault (Noble, 1954), which separates the Holcomb rocks from the felsic rocks of the Largo Vista area, also must be considered in this belt concept. The magnitude of displacement of this fault is not known but is probably not great, for the Holcomb rocks are grossly similar to some of the gneiss of Wrightwood.

\section{GNEISS OF THE WRIGHTWOOD AREA}

\section{SETTING AND GENERAL DESGRIPTION}

From the area of Cajon Pass northwestward for some 20 miles, gneissic rocks form a narrow belt of outcrop between the San Andreas fault on the south and Cenozoic deposits of the Mojave Desert on the north.

Most of the gneissic rocks in this belt are medium grained and medium to dark gray owing to the combination of white quartz and feldspar and black hornblende and biotite. $\mathbf{K}$-feldspar tends to be pinkish to salmon colored in the coarser, more felsic gneiss layers. In general the gneissic rocks are well banded, but there are gradations to more homogeneous rocks that could as well be called granofels. The more homogeneous variations, in part, look like the rocks of the Holcomb area. Dibblee's (written commun., 1967) distinction of quartz diorite and gneiss at the time he mapped this mass probably equates with an attempt to separate the more homogeneous rocks from the gneiss. Also coarser, apparently sweated-out, felsic layers have been in part mobilized and intruded into the surrounding rock as attested to by dikes and small plugs of similar composition. These small felsic masses are grossly similar to the felsic rock of Largo Vista that is associated with the Holcomb rocks.

The Wrightwood sequence is a highly metamorphosed sedimentary terrane whose map pattern suggests a homoclinal sequence, but local structural contortions and the general structural complexity of this area argue against this simple picture. The foliation is generally northwesterly with intermediate to steep dips to the northeast. Abundant marble layers, though locally contorted, also have the same trend. Most of the marble is concentrated in zones separated by gneiss sequences that are relatively marble free.
The few modes of the Wrightwood rocks presented in figure 19 and table 15 can hardly be considered a representative sample, but they do give some idea of the range in composition. It is tempting to speculate that the average composition of these widely scattered modes, which is close to the average of the rocks of the Holcomb area, represents the composition that homogenization of these rocks will yield.
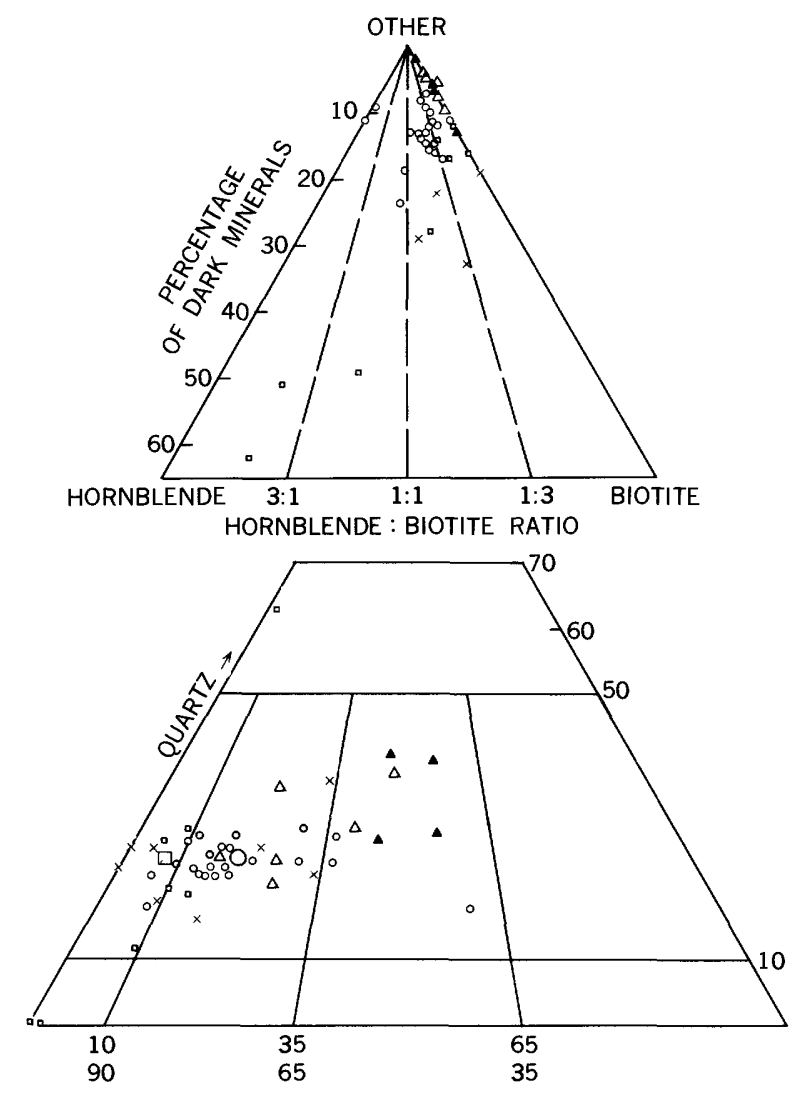

PLAGIOCLASE

EXPLANATION

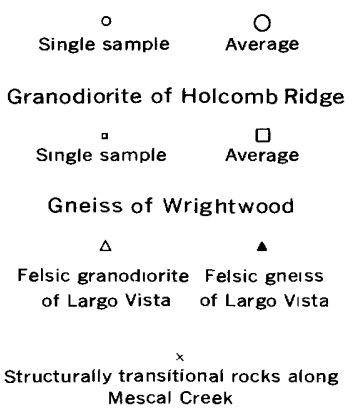

FIgURE 19. - Modal plot of basement rocks of the WrightwoodHolcomb area. 
PETROGRAPHIC, CHEMICAL STUDY, GRANITIC AND GNEISSIC ROCKS, SAN ANDREAS FAULT, CALIF.

TABLE 15.-Modes of basement rocks of the Wrightwood-Holcomb area

$[\mathbf{A}=$ apatite. $\mathbf{A}]=$ allanite. $\mathbf{T r} .=$ trace $. \mathrm{n} . \mathrm{d} .=$ not determined $]$

\begin{tabular}{|c|c|c|c|c|c|c|c|c|c|}
\hline No. & $\begin{array}{l}\text { Plagio- } \\
\text { clase }\end{array}$ & $\begin{array}{l}\text { K-feld- } \\
\text { spar }\end{array}$ & Quartz & $\begin{array}{c}\text { Bio- } \\
\text { tite }\end{array}$ & $\begin{array}{l}\text { Horn- } \\
\text { blende }\end{array}$ & $\begin{array}{l}\text { Metallic } \\
\text { opaque } \\
\text { min- } \\
\text { erals }\end{array}$ & Sphene & Other & $\begin{array}{l}\text { Specific } \\
\text { gravity }\end{array}$ \\
\hline \multicolumn{10}{|c|}{ Granodiorite of Holcomb } \\
\hline $\begin{array}{r}\mathrm{V}-2 \mathrm{~A}(65) \\
2 \mathrm{~B}(65) \\
2(66) \\
4(65) \\
4 \mathrm{~B}(65) \\
4(66) \\
\mathrm{DR}-207 \mathrm{~A} \\
210 \mathrm{~A} \\
220 \mathrm{~A} \\
221 \\
223 \\
225 \\
228 \\
229 \mathrm{~A} \\
231 \mathrm{~A} \\
235 \\
238 \\
286 \mathrm{~A} \\
360 \mathrm{~A} \\
360 \mathrm{~B} \\
413 \\
414\end{array}$ & $\begin{array}{l}54 \\
42 \\
54 \\
54 \\
51 \\
53 \\
56 \\
56 \\
53 \\
57 \\
56 \\
53 \\
56 \\
53 \\
60 \\
43 \\
58 \\
29 \\
52 \\
52 \\
44 \\
38\end{array}$ & $\begin{array}{r}11 \\
24 \\
11 \\
10 \\
11 \\
9 \\
10 \\
5 \\
7 \\
6 \\
10 \\
13 \\
9 \\
12 \\
4 \\
19 \\
6 \\
43 \\
15 \\
12 \\
19 \\
22\end{array}$ & $\begin{array}{l}24 \\
26 \\
19 \\
20 \\
23 \\
19 \\
23 \\
14 \\
25 \\
24 \\
20 \\
20 \\
20 \\
21 \\
19 \\
27 \\
21 \\
16 \\
23 \\
26 \\
21 \\
20\end{array}$ & $\begin{array}{r}8 \\
6 \\
9 \\
9 \\
9 \\
13 \\
11 \\
13 \\
11 \\
10 \\
9 \\
7 \\
9 \\
11 \\
6 \\
10 \\
-7 \\
7 \\
\text { Tr. } \\
11 \\
9\end{array}$ & $\begin{array}{r}2 \\
1 \\
5 \\
5 \\
3 \\
4 \\
11 \\
4 \\
2 \\
3 \\
6 \\
4 \\
4 \\
5 \\
2 \\
5 \\
11 \\
2 \\
9 \\
5 \\
10\end{array}$ & $\begin{array}{r}1 \\
1 \\
1 \\
1 \\
5 \\
1\end{array}$ & 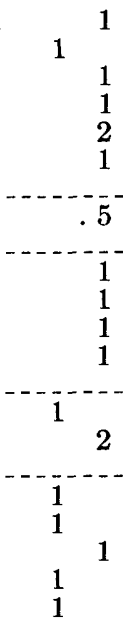 & 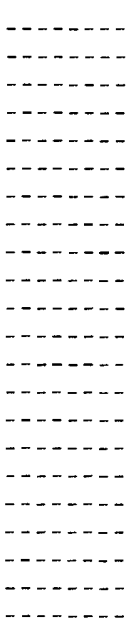 & $\begin{array}{l}\text { 2. } 71 \\
\text { 2. } 67 \\
\text { 2. } 72 \\
\text { 2. } 73 \\
\text { n.d. } \\
\text { 2. } 74 \\
2.69 \\
2.76 \\
2.72 \\
2.70 \\
2.71 \\
\text { 2. } 69 \\
\text { 2. } 74 \\
2.72 \\
2.71 \\
2.68 \\
2.72 \\
2.67 \\
2.69 \\
2.67 \\
2.70 \\
2.69\end{array}$ \\
\hline Average & 51 & 13 & 21 & 9 & 5 & .5 & .5 & $\ldots$ & 2. 70 \\
\hline \multicolumn{10}{|c|}{ Gneiss of Wrightwood } \\
\hline $\begin{array}{r}\text { DR-148A } \\
149 \mathrm{~A} \ldots \\
160 \mathrm{~A} \\
174 \ldots \\
176 \ldots \\
182 \mathrm{~A} \\
182 \mathrm{~B} \\
202 \mathrm{~A}\end{array}$ & $\begin{array}{l}54 \\
43 \\
49 \\
56 \\
59 \\
30 \\
41 \\
35\end{array}$ & $\begin{array}{r}5 \\
\text { Tr. } \\
3 \\
9 \\
7 \\
1 \\
4 \\
\text { Tr. }\end{array}$ & $\begin{array}{r}25 \\
-20 \\
16 \\
17 \\
53 \\
6 \\
\text { Tr. }\end{array}$ & $\begin{array}{r}16 \\
9 \\
17 \\
14 \\
11 \\
12 \\
18 \\
10\end{array}$ & $\begin{array}{r}42 \\
11 \\
3 \\
3 \\
-31 \\
52\end{array}$ & $\begin{array}{l}6 \\
1 \\
1 \\
4 \\
-2\end{array}$ & $\begin{array}{r}1 \\
2 \\
\end{array}$ & (Ap) 1 & $\begin{array}{l}\text { 2. } 70 \\
2.99 \\
\text { 2. } 76 \\
\text { 2. } 72 \\
\text { 2. } 73 \\
\text { 2. } 78 \\
\text { 2. } 85 \\
2.96\end{array}$ \\
\hline Average...... & 46 & 4 & 17 & 13 & 18 & 2 & $<1$ & - & 2. 81 \\
\hline \multicolumn{10}{|c|}{ Felsic gneiss of Largo Vista } \\
\hline $\begin{array}{r}\text { DR-206A } \\
210 \mathrm{~B} \\
212 \\
226 \mathrm{~A}\end{array}$ & $\begin{array}{l}29 \\
35 \\
31 \\
25\end{array}$ & $\begin{array}{l}25 \\
28 \\
38 \\
30\end{array}$ & $\begin{array}{l}37 \\
24 \\
28 \\
37\end{array}$ & $\begin{array}{r}6 \\
12 \\
2 \\
7\end{array}$ & (-n- & $\begin{array}{r}1.5 \\
1\end{array}$ & $\begin{array}{r}1.5 \\
1 \\
1\end{array}$ & 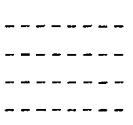 & $\begin{array}{l}\text { 2. } 69 \\
\text { 2. } 66 \\
\text { 2. } 61 \\
\text { 2. } 67\end{array}$ \\
\hline Average..... & 30 & 30 & 32 & 7 & - n & & 1 & $\ldots$ & 2. 66 \\
\hline \multicolumn{10}{|c|}{ Felsic granodiorite of Largo Vista } \\
\hline $\begin{array}{r}\text { DR-207B } \\
208 \\
215 \\
959 \\
962 \\
963 \mathrm{~B}_{1}\end{array}$ & $\begin{array}{l}31 \\
40 \\
44 \\
50 \\
56 \\
54\end{array}$ & $\begin{array}{l}27 \\
27 \\
14 \\
18 \\
11 \\
20\end{array}$ & $\begin{array}{l}35 \\
28 \\
33 \\
23 \\
23 \\
21\end{array}$ & $\begin{array}{r}6 \\
5 \\
8 \\
10 \\
5\end{array}$ & Tr. & 1 & & $\begin{array}{l}-1 \\
\cdots-1 \\
\cdots-1\end{array}$ & $\begin{array}{l}2.65 \\
2.65 \\
2.65 \\
2.69 \\
2.68 \\
2.65\end{array}$ \\
\hline Average_._. - & 46 & 20 & 27 & 7 & & & & & 2. 66 \\
\hline
\end{tabular}


TABLE 15.-Modes of basement rocks of the Wrightwood-Holcomb area-Continued

\begin{tabular}{|c|c|c|c|c|c|c|c|c|c|}
\hline No. & $\begin{array}{l}\text { Plagio- } \\
\text { clase }\end{array}$ & $\begin{array}{l}\text { K-feld- } \\
\text { spar }\end{array}$ & Quartz & $\begin{array}{l}\text { Bio- } \\
\text { tite }\end{array}$ & $\begin{array}{l}\text { Horn- } \\
\text { blende }\end{array}$ & $\begin{array}{c}\text { Metallic } \\
\text { opaque } \\
\text { min- } \\
\text { erals }\end{array}$ & Sphene & Other & $\begin{array}{l}\text { Specific } \\
\text { gravity }\end{array}$ \\
\hline \multicolumn{10}{|c|}{ Structurally transitional rocks along Mescal Creek } \\
\hline $\begin{array}{r}\text { DR-956 } \\
\mathbf{9 6 5} \mathrm{A} \\
\mathbf{9 6 5} \mathrm{B} \\
\mathbf{9 6 6} \mathrm{B} \\
\mathbf{9 6 6} \mathrm{C} \\
\mathbf{9 6 8} \\
\mathbf{9 6 9} \\
\mathbf{9 7 0}\end{array}$ & $\begin{array}{l}\mathbf{4 1} \\
\mathbf{5 1} \\
\mathbf{5 0} \\
\mathbf{5 6} \\
39 \\
\mathbf{6 1} \\
\mathbf{6 2} \\
\mathbf{5 0}\end{array}$ & $\begin{array}{r}21 \\
-2 \\
\text { Tr. } \\
19 \\
12 \\
6 \\
15\end{array}$ & $\begin{array}{l}19 \\
16 \\
19 \\
21 \\
34 \\
14 \\
16 \\
24\end{array}$ & $\begin{array}{l}19 \\
24 \\
16 \\
15\end{array}$ & $\begin{array}{rr} & 9 \\
& 13 \\
8 & 7 \\
13 & \\
16 & \\
11 & \end{array}$ & 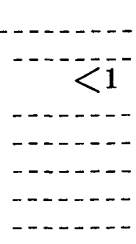 & 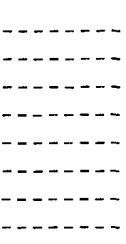 & $(\mathrm{A} \bar{l}) \overline{1}$ & $\begin{array}{l}2.73 \\
2.77 \\
2.76 \\
2.77 \\
2.69 \\
2.71 \\
2.73 \\
2.70\end{array}$ \\
\hline Average_...- & 51 & 9 & 20 & & 20 & & . & 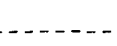 & 2. 73 \\
\hline
\end{tabular}

\section{MICROSCOPIC DESCRIPTION}

The texture of these rocks in thin section can probably best be described as granoblastic. Though foliation is evident in most sections, the overall fabric is fairly nondirectional. In some of the more highly foliated rocks, however, dark minerals are molded around quartz and feldspar to produce an incipient augen structure. The less well foliated rocks are hornfelsic, and the texture in some merges to granitic (xenomorphic-granular). In texture and overall mineralogy, these rocks are reminiscent of the rocks of the Red Hills, and to a lesser extent some of the more felsic gneisses look like the rocks of Barrett Ridge.

Plagioclase in these rocks is invariably sharply twinned and well zoned. It ranges from fresh to intensely sericitized. The plagioclase is generally in the same compositional range as the Holcomb rocks, sodic to intermediate andesine. The crystals are mostly anhedral, but some are subhedral.

$\mathrm{K}$-feldspar ranges from sparse interstitial stringers in the gneiss of quartz diorite composition to about a third of the rock in the intruded quartz monzonite and the coarser, felsic layers in the gneiss. The coarser grains are irregular and poikilitic. Locally these crystals have grown to an inch in length. In one specimen a sweatedout dikelet of $\mathbf{K}$-feldspar-rich material cuts across the foliation with a sharp contact on one side and a gradational contact on the other.

Quartz is abundant in most specimens and ranges from masses a few millimeters across that are mosaicked and show undulatory extinction, to granulated interstitial trains of grains. These highly sutured interstitial trains of grains are strongly shape oriented and are in part molded around more resistant plagioclase to present an anastomosing pattern, approaching an augen texture. In some specimens, rounded quartz grains are scattered in other minerals, particularly hornblende and plagioclase. The quartz in all specimens shows some degree of strain, but mortar structure is extremely rare. Myrmekite is rather widespread.

Brown biotite is present in all specimens. It is generally in irregular crystals of various sizes, and its alinement is one of the main markers of the foliation. Chloritization of the biotite is widespread but variable. The biotite pleochroism is $\mathbf{X}=$ grayish yellow to grayish orange and $Z=$ moderate to dark yellowish brown. Much of the biotite has reddish tints in part.

Green hornblende has a very spotty distribution in this unit. It is absent in many of the gneissic layers, even in some with abundant dark minerals, where it would be expected. It occurs in small amounts in the somewhat homogenized gneiss (specimens 174,176 ) that bears some resemblance to the Red Hills rock, and it is a major constituent of the amphibolite layers (specimens 149, 182, 202). Locally such rocks are coarse grained. Hornblende crystals are generally irregular shaped, but are better formed in the coarser grained hornblende-rich rocks. Epidote and chloritic alteration products are present, but most of the hornblende is rather fresh. Some is lighter green than typical hornblende of the Holcomb rocks, but this is not common. The pleochroism is $\mathrm{X}=$ moderate greenish yellow, $\mathrm{Y}=$ light olive, and $Z=$ grayish green to moderate yellowish green.

Rather abundant small crystals of red garnet were found in one dark layer in the gneissic rocks (specimen 149). The garnet, probably almandine, is nearly colorless in thin section and has an index of refraction greater than 1.800 .

The accessory minerals zircon, apatite, sphene, metallic opaque minerals, and to a lesser extent allanite are widespread, but vary in abundance. Metallic opaque minerals have the widest range-they make up as much as 6 percent of some of the amphibolitic rocks (specimen 
149A) but are absent from some other rocks (specimen $160 \mathrm{~A}$ ). Several other gneiss specimens have mere traces of metallic opaque minerals. Sphene content, also highly variable, is as much as much as 2 percent in some rocks and in very small amounts in others. Zircon is widespread and rather abundant; it seems to occur both as euhedral crystals and rounded, possibly detrital grains. Apatite, sphene, and allanite are also commonly rounded and look detrital. In general, the abundance of rounded accessory minerals, of the kinds common in granitic rocks, suggests that the gneiss complex of Wrightwood is metamorphosed from a sedimentary pile that had a largely granitic source.

\section{METAMORPHIC MINERALS IN MARBLE LAYERS}

In the gneiss sequence east of Wrightwood, prominent dark phlogopite flakes as large as $3 \mathrm{~mm}$ across pepper layers and lenses of marble, which is largely coarsegrained calcite. This appears to be an extremely noteworthy, if not unique, occurrence of abundant, coarse phlogopite in marble in this region. Phlogopite is not uncommon in marble, but its abundance and coarseness here seem unusual.

The phlogopite is brownish to opaque black in hand specimen and is various shades of orange and brown in thin flakes; some is almost colorless. The $2 \mathrm{~V}$ is very small, and some crystals appear to be uniaxial. The range in beta index is shown below :

\section{Metamorphic minerals in marble layers of gneiss of Wrightwood \\ Specimen
DR-151A A \\ 151B $\ldots$ Phlogopite $\left(n_{\beta}=1.567-1.562\right)$, chrysotile, graph- ite. \\ $152 \mathrm{~A}_{\text {_... }}$ Phlogopite $\left(n_{\beta}=1.588\right)$, tremolite, quartz \\ 153 . . . . Phlogopite $\left(n_{\beta}=1.558-1.580\right)$, tremolite \\ $155 \mathrm{~A}$...- Phlogopite $\left(n_{\beta}=1.590\right)$, chlorite, talc, quartz, hornblende(?). \\ 156 . . . - Phlogopite $\left(n_{\beta}=1.577-1.598\right)$, chlorite, quartz \\ 157 - . Phlogopite $\left(n_{\beta}=1.575\right)$, talc, graphite, quartz(?). \\ $177 \ldots \ldots$ Phlogopite $\left(n_{\beta}=1.574-1.578\right)$, graphite.}

In general, the darker the flakes, the higher the index of refraction. Serpentine minerals (mostly chrysotile), tremolite, graphite, chlorite, and talc are associated with the phlogopite in varying but generally small amounts.

This general assemblage of minerals is suggestive of the albite-epidote hornfels facies of contact metamorphism (Fyfe and others, 1958, p. 203), but the association of these marble layers with medium- to coarsegrained quartzo-feldspathic gneisses suggests a higher grade of metamorphism.

\section{DISTINGUISHING FEATURES}

The general appearance or mineralogy of the gneiss of Wrightwood is not particularly distinctive. The absence of hornblende in layers that are relatively rich in dark minerals may be noteworthy. Also, the fact that the well-banded gneissic sequence grades into more homogeneous, dioritic masses and that locally sweatedout layers are rich in salmon-pink K-feldspar may be distinctive.

Layers of marble are probably the most characteristic feature of this gneiss terrane. The abundance of dark flakes of phlogopite in the marble in the eastern part of the gneiss belt is probably the single most distinctive feature of this group of rocks.

\section{GRANODIORITE OF HOLGOMB RIDGE}

SETTING AND GENERAL DESGRIPTION

A thin discontinuous belt of granodiorite, the granodiorite of Holcomb Ridge, underlies an area of about 20 square miles, from the vicinity of Llano westward to Palmdale. These rocks are light to medium dark gray, owing to the combination of white to clear quartz and feldspar, and black biotite and hornblende. Most of the rocks are medium grained, but locally some are finer grained. Generally the rocks are equigranular, but poikilitic K-feldspar phenocrysts (or porphyroblasts) up to 1 inch in length occur locally; some of these are pinkish. Scattered well-shaped hornblende crystals are also characteristic of this mass. Although biotite is the dominant dark mineral in most specimens, hornblende is abundant in places and is dominant locally. Honeybrown sphene crystals are large enough to be readily obvious in some hand specimens.

Foliation is very prevalent in this unit; possibly it is somewhat less well developed in the northwestern part of the belt of outcrop. It is most commonly shown by alinement of dark minerals. Preferred orientation of quartz and feldspar is more subtle, but is clearly shown on some stained rocks surfaces. Foliation is also accentuated by gneissic patches and schlieren in the granodiorite; these are very distinctive in some places and are subtle, almost ghostlike remnants elsewhere. The foliation is notably concordant with bedding of included marble layers.

The general modal range as shown by figure 19 and table 15 has considerable spread, but there is a rather good grouping of most specimens in the granodiorite field. The one really aberrant point (specimen $286 \mathrm{~A}$ ) is from mixed rocks that show strong local variation in $\mathrm{K}$-feldspar. The range (if $286 \mathrm{~A}$ is excepted) and trend are certainly compatible with a not too heterogeneous intrusive granitic rock. On the other hand, the compositional trend and range of the Holcomb Ridge rocks may be indicative of a homogenized end member of a gneissic complex (the Wrightwood rocks). 
Aplite, alaskite, and coarse-grained simple pegmatite with pinkish K-feldspar are locally very abundant. Some of these felsic rocks are somewhat foliated and are intruded as sills parallel to the granitic foliation. Hornblende diorite and gabbro, of coarse and variable grain size, are present locally, most commonly northwest of Valyermo.

\section{MICROSCOPIC DESCRIPTION}

The texture of the Holcomb Ridge rocks ranges from hypautomorphic- to xenomorphic-granular; some look almost granoblastic. In general the texture is irregular. Quartz ranges from slivers to larger sutured, mosaicked masses; dark minerals are irregular and shredlike in part. Almost invariably these rocks show some foliation, mostly by preferred orientation of the dark minerals, but also by elongation of interstitial $K$-feldspar and particularly quartz. In some specimens, strongly alined quartz and dark minerals are wrapped around feldspar grains to produce an incipient augen structure. Bent biotite books and warped twinning in plagioclase also mark strain in some specimens.

Plagioclase in the Holcomb rocks is sharply and cleanly twinned and oscillatorily zoned. Some is remarkably fresh, but sericitic alteration is present to some degree in most specimens. The zoning range does not seem to be great; most is in the sodic to intermediate andesine range.

The $\mathrm{K}$-feldspar content is rather variable, and the habit of the mineral ranges from interstitial stringers to poikilitic phenocrysts or porphyroblasts. The larger $\mathrm{K}$-feldspar crystals invariably engulf all the other minerals of the rock; particularly noteworthy and rather widespread are inclusions of rounded quartz grains. Small amounts of myrmekite are present in most specimens. The myrmekite seems particularly abundant in association with the intricately sutured and mosaicked quartz of some specimens.

Quartz is abundant in these rocks and is distinctive because it commonly is intricately sutured and mosaicked. The range in quartz habit is rather large: some crystals are merely weakly undulatory, but in the same thin section quartz may be in sutured, mosaicked masses and in thinly slivered, strongly oriented interstitial masses that are molded around other minerals, mostly plagioclase. In general, the quartz shows the effects of moderate to intense strain.

Brown biotite is present throughout the mass. It is mostly in irregular to shredlike crystals and is somewhat altered to chlorite in most rocks. Associated with this alteration are stringers of sphene and some magnetite. Pleochroism is generally $\mathbf{X}=$ grayish yellow to grayish orange and $\mathrm{Z}=$ moderate yellowish brown to moderate brown. Some specimens have a reddish tint.

Green hornblende is generally less abundant than biotite, but locally it may be the only dark mineral. It may also be absent. Although crystals are generally irregular shaped, some crystals are nearly euhedral. Even the euhedral crystals, however, tend to be "spongy" with lacy irregular margins. Some inclusions of epidote, chlorite, and calcite appear to be the result of alteration, but most of the hornblende is essentially fresh. The pleochroism is $\mathrm{X}=$ moderate greenish yellow, $\mathrm{Y}=$ light olive, and $Z=$ dark yellowish green, moderate yellowish green, and grayish green.

The usual accessory minerals of granitic rockssphene, apatite, metallic opaque minerals, zircon, and allanite-are present in most specimens. Allanite seems to be particularly abundant in some of the finer grained rocks. Metallic opaque minerals are virtually absent in some specimens, one of which (specimen 210A) seems particularly unusual, for it has abundant normal-looking hornblende and biotite and thus would be expected to contain abundant metallic opaque minerals. The same specimen also has irregular sphene crystals, whereas most other specimens have wedge-shaped crystals. In some specimens, sphene contains metallic opaque inclusions; in others, the sphene and metallic minerals seem to cluster together with the dark minerals, but the sphene lacks inclusions. Well-formed discrete epidote crystals in some specimens look primary.

\section{DISTINGUISHING FEATURES}

The overall appearance of this rock, particularly in the Holcomb Ridge area, is somewhat distinctive. The general abundance of dark minerals, the presence of well-formed coarse hormblende, the conspicuous foliation, and the presence of gneissic zones and patches serve to identify the unit. Also noted is the rarity of dark dioritic inclusions that one might expect to be abundant in a granitic rock of this composition.

The most distinctive features of this mass are the gneissic patches and lenses that are grossly concordant with both the granitic foliation and the bedding in the included marble layers. And to further emphasize a point, the regional grain in the Holcomb rocks is concordant with the regional grain of the gneiss of Wrightwood.

\section{ROCKS STRUCTURALLY TRANSITIONAL BETWEEN HOLCOMB AND WRIGHTWOOD TYPES}

Rocks along Mescal Creek and farther east are included with the gneiss of Wrightwood because although they have an almost granitic texture, they are in gneissic 
GNEISSIC ROCKS, SAN ANDREAS FAULT, CALIF.

layers. They are not intrusive sills, but are largely gneissic rocks that have been homogenized or ultrametamorphosed to a near-granitic appearance. In addition, there are gradationally bordered bodies of gneiss in the granodiorite of Holcomb Ridge that further accentuate the transition between these two rock types.

In hand specimen these rocks are mainly intermediate shades of gray. Their texture ranges from weakly gneissic to xenomorphic-granular; many could be called either, but in view of their association with dominantly gneissic rocks, granoblastic is a fitting term for most. The plagioclase (andesine) is cleanly twinned and in part well zoned, and it has an igneous appearance despite being present in a gneissic sequence. These rocks have a considerable range of plagioclase and $\mathrm{K}$-feldspar content (fig. 19 ; table 15), and they commonly have intricately sutured and mosaicked quartz. Dark minerals are abundant; biotite is generally in excess of hornblende. Biotite is pleochroic from $\mathrm{X}=$ moderate to grayish yellow and grayish orange to $Z=$ moderate olive brown and other shades of brown. Hornblende is pleochroic as follows: $\mathrm{X}=$ moderate greenish yellow, $\mathrm{Y}=$ light olive, $Z=$ moderate to dusky yellowish green. The normal granitic accessory minerals are present, but allanite is unusually abundant in one specimen.

\section{FELSIC GRANODIORITE OF LARGO VISTA}

The rocks designated "Largo Vista" on plate 2 are finer grained and more felsic than the Holcomb Ridge rocks, but may locally grade to similar rocks. They are most common in the belt of outcrop designated "Largo Vista" on plate 2, north of the gneiss of Wrightwood, although they are also present within the area shown on "Wrightwood" on plate 2. Some are seriate, and wisps of ghost gneiss and gneissic layers are present locally. Similar felsic rocks are also present near the head of Mescal Creek. These rocks seem intimately related to a felsic gneiss along the Largo Vista road. (See next section.) They may be a separate intrusive unit, or material sweated out and mobilized from the felsic gneiss.

The granodiorite is medium to fine grained and ranges from equigranular to seriate. Nothing in thand specimen or thin section distinguishes it. The plagioclase is andesine and is oscillatorily zoned. Biotite is generally the only dark mineral; grayish-green hornblende is present locally. The biotite is pleochroic from $\mathrm{X}=$ pale yellowish orange and grayish yellow to $Z=$ various shades of moderate to dark brown. Allanite and zircon seem particularly abundant in some specimens. Metallic opaque minerals, sphene, and apatite are also present.

\section{FELSIC GNEISS OF LARGO VISTA}

Gneissic specimens from along the Largo Vista road are somewhat lighter and contain much more potassium feldspar than most Wrightwood gneiss specimens to the east. The extent of this felsic variation is not known, but it is virtually certain these rocks are part of the Wrightwood suite, for they grade to typical gneiss of Wrightwood. The felsic gneisses are well banded, but some bands are diffuse and the rocks approach a granitic appearance, which is in part aplitic. As can be seen from figure 19 and table 15 , these rocks have the composition of quartz monzonite. The plagioclase is andesine; the sole dark mineral is biotite, which is pleochroic from $X=$ grayish yellow and orange to $Z=\bmod$ erate brown and moderate yellowish brown. Sphene and metallic opaque minerals are generally common, and in some specimens zircon is abundant. Petrographically these rocks are rather nondescript.

\section{GNEISS OF PINYON RIDGE}

Between the San Andreas fault and the Punchbowl fault (Noble, 1954) in the Valyermo area, the basement rock is dominantly gneiss, with lesser amounts of granitic rock. Originally Noble (1954) named this unit the Pinyon Ridge Granodiorite, but he noted that it commonly contained gneissic rocks.

These rocks have a gross similarity to the gneiss of Wrightwood, but varieties rich in euhedral hornblende crystals are more common on Pinyon Ridge. Also, carbonate rocks do not seem to be present on Pinyon Ridge. Homogenization of some of the Pinyon Ridge gneiss appears to have yielded granitic-looking rocks; this process has also occurred in the Wrightwood gneiss. A few modes are summarized in figure 20 and table 16 .

The gneissic rocks are commonly various shades of gray and range from well banded through gradational irregular textures to the homogeneous rocks that caused Noble (1954) to characterize this mass as granodiorite. Most of the plagioclase is andesine, but some is oligoclase. Some of the more homogeneous specimens have concentrically zoned plagioclase. $\mathrm{K}$-feldspar rather typically is irregularly distributed. Much quartz is intricately sutured and mosaicked.

Well-formed hornblende is widespread enough to be typical of this gneiss, and the ratio of hornblende to biotite varies considerably. The hornblende is typical green "granitic" amphibole that is pleochroic from $\mathrm{X}=$ moderate greenish yellow, to $\mathrm{Y}=$ light olive, to $\mathrm{Z}=$ moderate yellowish green and grayish green. Brown biotite commonly is intensely chloritized, but where fresh is pleochroic from $\mathbf{X}=$ grayish to moderate yellow and grayish orange to $Z=$ shades of brown. Metallic 


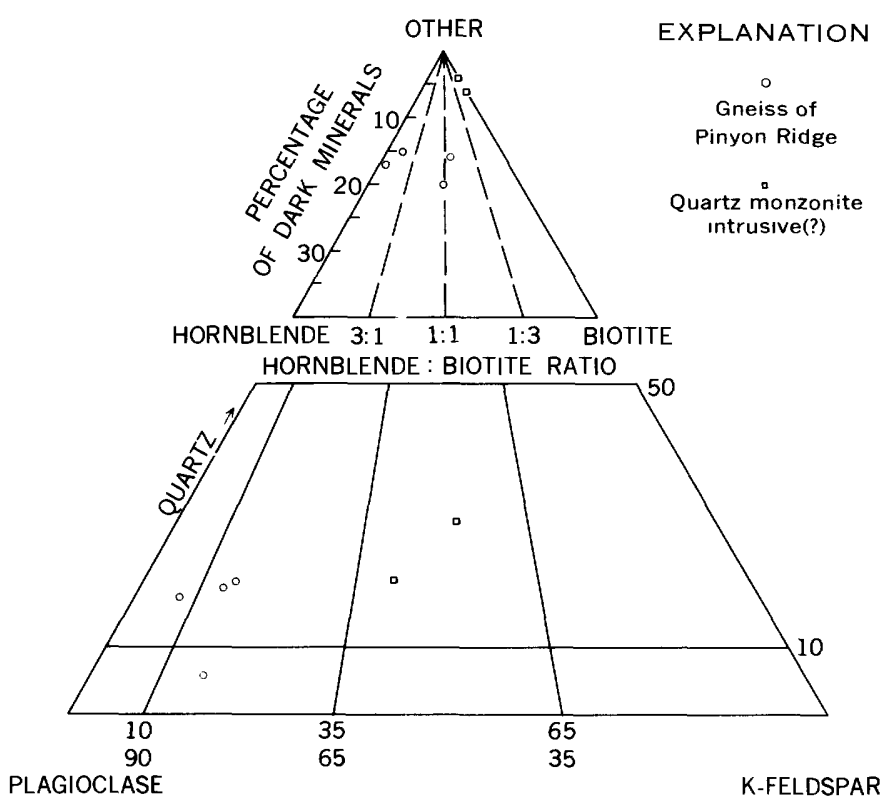

Figure 20.-Modal plot of the Pinyon Ridge area.

TABLE 16.-Modes of rocks of Pinyon Ridge $[\mathrm{S}=$ sphene $]$

\begin{tabular}{|c|c|c|c|c|c|c|c|}
\hline No. & $\begin{array}{l}\text { Plagio- } \\
\text { clase }\end{array}$ & $\underset{\text { spar }}{\text { K-feld- }}$ & Quartz & Biotite & $\begin{array}{c}\text { Horn- } \\
\text { blende }\end{array}$ & Other & $\begin{array}{l}\text { Specific } \\
\text { gravity }\end{array}$ \\
\hline \multicolumn{8}{|c|}{ Gnelss } \\
\hline $\begin{array}{r}\text { DR-190 } \\
197 \ldots \\
363 . \ldots \\
365 \\
\end{array}$ & $\begin{array}{l}56 \\
56 \\
67 \\
63\end{array}$ & $\begin{array}{r}9 \\
10 \\
13 \\
5\end{array}$ & $\begin{array}{r}15 \\
17 \\
5 \\
15\end{array}$ & $\begin{array}{r}10 \\
9 \\
2 \\
1\end{array}$ & $\begin{array}{l}10 \\
7 \\
13 \\
16\end{array}$ & (S) 1 & $\begin{array}{l}2.74 \\
2.73 \\
2.74 \\
2.64(?)\end{array}$ \\
\hline \multicolumn{8}{|c|}{ Quartz monzonite } \\
\hline $\begin{array}{r}\text { DR-372 } \\
373 .\end{array}$ & $\begin{array}{l}33 \\
44\end{array}$ & $\begin{array}{l}35 \\
31\end{array}$ & $\begin{array}{l}28 \\
19\end{array}$ & $\begin{array}{l}4 \\
6\end{array}$ & & & $\begin{array}{l}2.61 \\
2.62\end{array}$ \\
\hline
\end{tabular}

opaque minerals, sphene, apatite, zircon, and allanite are present as accessary minerals.

Some coarse-grained felsic quartz monzonite appears to intrude the gneissic and granodioritic sequence, and pegmatite is also intrusive, but not abundant.

\section{GRANODIORITE OF FAIRMONT RESERVOIR}

\section{SETTING AND GENERAL DESCRIPTION}

The granodiorite of the Fairmont Reservoir is exposed between Antelope Valley and the San Andreas fault along a 16-mile segment that is no more than 3 miles wide. West of the specimen 615 locality, a long thin tongue of alluvium separates Fairmont rocks from a granitic rock that is distinctly different, at least in exposures examined near the San Andreas fault. The northern part of this area was not examined, and pos- sibly it also includes Fairmont rocks. The poorly exposed granitic rocks of Fairmont Butte have not been examined either; they may well be the Fairmont type. Thus, this rather homogenous granitic rock is exposed over an area of at least 20 square miles, and additional exposures may exist at two localities.

The rock is white to gray and liberally mottled with black biotite and some hornblende. Both honey-brown sphene and green epidote are visible in some hand specimens. The grain size varies somewhat, and some specimens have an almost salt-and-pepper look. Sparsely scattered through the rock are pinkish $\mathrm{K}$-feldspar crystals as much as $25 \mathrm{~mm}$ long. Small dark inclusions and schlieren locally are relatively abundant and, along with elongated dark minerals, define a foliation. Generally, however, inclusions and schlieren are rare. Foliation with the form of streaking is locally reflected by grainsize variation and dark-mineral concentration. Gougefilled thin shear zones are locally present, but mostly this rock shows only minor evidence of shearing. Aplite, alaskite, and pegmatite in small dikes and masses intrude the granodiorite. Coarser and more felsic rocks represented by specimens $590,592,595 \mathrm{~B}$, and $600 \mathrm{~A}$ may be intrusive into the granodiorite, or they must be variants of the granodiorite. They do seem to be modally quite distinct from the bulk of the Fairmont rocks.

Figure 21 and table 17 show the modal variation of this mass. Perhaps the most noteworthy characteristic is the almost constant quartz percentage in specimens that span the granodiorite and quartz diorite fields.

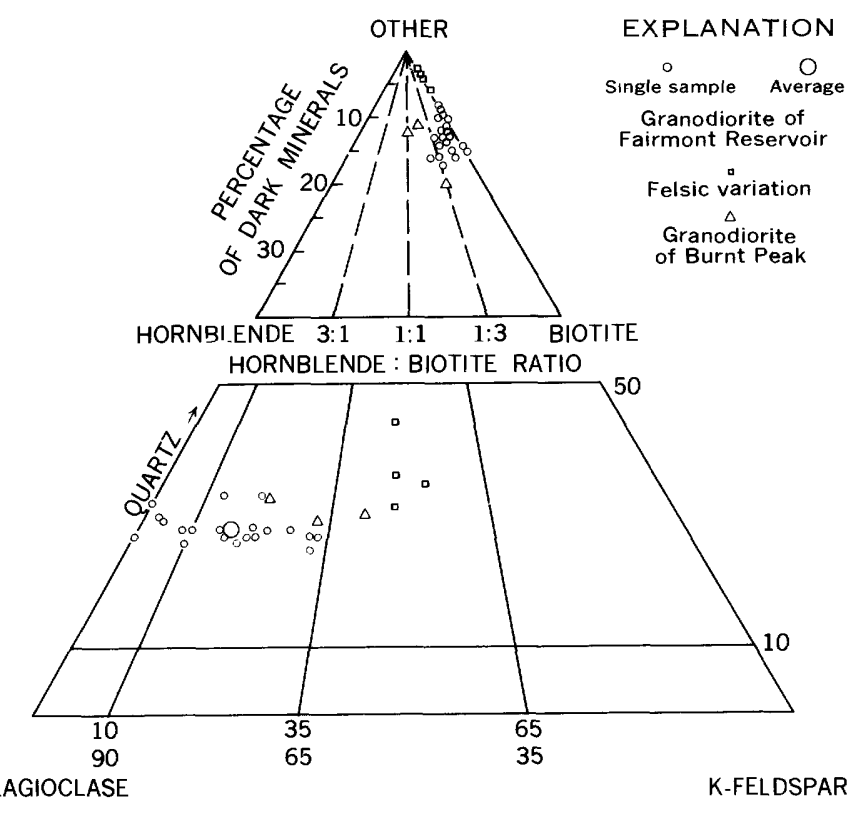

Figure 21.-Modal plot of rocks of Fairmont Reservoir area. 
TABLE 17.-Modes of rocks of Fairmont Reservoir area

$[\mathrm{S}=$ sphene, $\mathrm{E}=$ epidote, $\mathrm{Me}=$ metallic opaque minerals, n.d.=not determined]

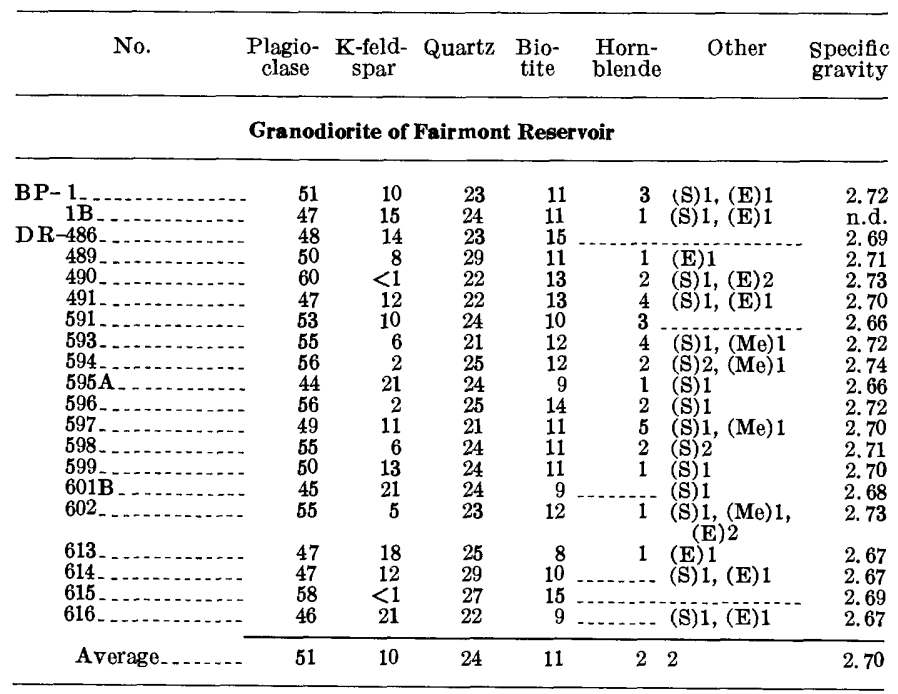

Felsic rocks of Fairmont Reservoir area

\begin{tabular}{|c|c|c|c|c|c|}
\hline $\begin{array}{r}\text { DR } 590 \\
592 \\
595 \mathrm{~B} \\
600 \mathrm{~A}\end{array}$ & $\begin{array}{l}32 \\
29 \\
36 \\
30\end{array}$ & $\begin{array}{l}28 \\
25 \\
31 \\
33\end{array}$ & $\begin{array}{l}34 \\
42 \\
30 \\
33\end{array}$ & $\begin{array}{l}6 \\
6 \\
3 \\
3 \\
4\end{array}$ & $\begin{array}{l}2.62 \\
2.64 \\
2.65 \\
2.60\end{array}$ \\
\hline Average. & 32 & 29 & 35 & 4 & 2.8 \\
\hline
\end{tabular}

Granodiorite of Burnt Peak (Burnt Peak No. 2 type)

\begin{tabular}{|c|c|c|c|c|c|c|}
\hline $\begin{array}{l}\text { BP- } 2 \\
\text { DR-617- } \\
\quad 618\end{array}$ & $\begin{array}{l}42 \\
42 \\
36\end{array}$ & $\begin{array}{l}20 \\
11 \\
25\end{array}$ & $\begin{array}{l}25 \\
26 \\
26\end{array}$ & $\begin{array}{r}6 \\
15 \\
7\end{array}$ & $\begin{array}{ll}6 & (\mathrm{~S}, \mathrm{E}) 1 \\
5 & (\mathrm{~S}, \mathrm{E}) 1 \\
4 & (\mathrm{~S}) 2\end{array}$ & $\begin{array}{l}2.69 \\
2.66 \\
2.65\end{array}$ \\
\hline Average & 40 & 19 & 26 & 9 & $\begin{array}{ll}5 & 1 \\
\end{array}$ & 2.67 \\
\hline
\end{tabular}

\section{MIGROSCOPIC DESGRIPTION}

In general these rocks are hypautomorphic-granular to seriate and little altered. Plagioclase, in well-formed crystals, is cleanly twinned and oscillatorily zoned, and most is sodic andesine. $\mathbf{K}$-feldspar content ranges from traces to more than 20 percent. The mineral ranges from small interstitial grains to large poikilitic crystals that characteristically include all other constituents of the rock. Most of the quartz is rather strongly mosaicked and sutured and in part granulated, but locally the quartz is virtually unstrained. Biotite as irregular crystals is the common dark mineral. It is pleochroic from $\mathrm{X}=$ grayish orange to grayish yellow to $Z=$ light to moderate olive brown and less commonly moderate to dark yellowish brown or light olive. In some specimens the olive to brown biotite grades to a grass-green variety with high birefringence that may represent a transitional stage in chloritization. Hornblende ranges from irregular shreds to rather well-formed bladed crystals. Pleochroism is $\mathrm{X}=$ moderate greenish yellow, $\mathrm{Y}=$ light to grayish olive, and $Z=$ moderate yellowish green.

Sphene is abundant in irregular to euhedral wedgeshaped crystals that commonly contain inclusions of metallic opaque minerals, probably mostly, if not all, magnetite. Some of the inclusions have shapes vaguely reminiscent of Arabic characters; others are droplike. Allanite (in part rimmed with epidote), zircon, and apatite are also present. Epidote is common in these rocks, yet alteration of dark minerals is extremely uncommon. At least some of the epidote is probably primary.

The felsic rocks, mentioned above, generally are xenomorphic-granular and almost aplitic. Rounded quartz grains are the most characteristic differences from the granodiorite. Also, the felsic rocks lack hornblende. Other than this, there is little to distinguish them in thin section from the granodiorite.

\section{DISTINGUISHING FEATURES}

In hand specimen these rocks are not particularly distinctive. Modally, the constant quartz percentage through the range from granodiorite to quartz diorite is noteworthy. In thin section, the abundance of sphene, magnetite, and epidote is significant. The abundance of euhedral sphene with numerous magnetite inclusions is distinctive.

\section{GRANODIORITE OF BURNT PEAK}

West of the westernmost outcrops of the granodiorite of Fairmont Reservoir, across an alluviated valley, the granitic rock of Burnt Peak is distinctly different. Hornblende is abundant and well formed, and the general texture of the rock is different from the Fairmont Reservoir type. Unfortunately, a gap of about 2 miles separates samples of the two types, and it is possible that the two types could be variants of one mass. However certain features seem dissimilar enough to at least point out the possibility that the rock of Burnt Peak is a separate mass.

The Burnt Peak rocks in part have a striking texture with well-formed plagioclase, $\mathrm{K}$-feldspar, and dark minerals. Hornblende, particularly, and even some biotite are euhedral. The general modal composition, however, is not too different from Fairmont Reservoir speciments (fig. 21 ; table 17). Hornblende is generally more abundant relative to biotite than in the Fairmont rock, but because the samples are few, this is a shaky conclusion. Biotite is pleochroic from $\mathrm{X}=$ grayish yellow to grayish orange to $Z=$ light olive. Hornblende is pleochroic as follows: $\mathrm{X}=$ moderate greenish yellow, $\mathrm{Y}=$ light olive to moderate olive brown, and $Z=$ moderate yellowish green to moderate green.

Sphene is an abundant accessory, partly as euhedral crystals. Zircon, apatite, and mere traces of metallic opaque minerals in hornblende comprise the remainder 
of the accessories. Alteration products-epidote, chlorite, and sericite-are relatively abundant.

The rarity of metallic opaque minerals in a rock with abundant dark minerals, particularly hornblende, is in marked contrast to the abundance of opaque minerals in the Fairmont Reservoir rocks.

\section{GNEISSIC GRANITIC ROCKS OF BOUQUET RESERVOIR}

\section{SETTING AND GENERAL DESGRIPTION}

Gneissic granitic rocks form a 5-mile-wide belt that extends from the San Andreas fault westward more than 20 miles between schistose rocks of the Sierra Pelona on the south and granitic rocks of Liebre Mountain on the north. Only the eastern part of this mass has been sampled, and very sparsely at that. The only part of the mass that can be described with any confidence is a belt along the south side of the mass from the San Andreas fault to the area of Bouquet Reservoir.

The rocks of this belt, though variable in details, have a gross similarity. Most are relatively dark colored and are medium to coarse grained with an irregular somewhat splotchy overall texture. All these rocks are foliated to some degree, but only a few are gneissic. The fabric is more granitic than metamorphic; there is a general resemblance in part to the granodiorite of Holcomb Ridge, though most of the Bouquet Reservoir rocks are somewhat darker. The Bouquet Reservoir rocks could be regarded as either homogenized gneissic rocks or somewhat gneissic granitic rocks.

Scattered observations north of the sampled belt suggest that Bouquet Reservoir rocks are more gneissic and are in part highly contorted. Also, there appear to be some hybrid rocks that, though somewhat granitic looking, have unusual mineralogy (specimen 488). Aplite, alaskite, and simple pegmatite intrude the Bouquet Reservoir rocks, in variable amounts.

The modes (fig. 22; table 18) show an interesting trend, plunging steeply toward the plagioclase corner of the triangle, but more samples are needed from elsewhere in the mass to determine if this trend is representative. Most of the samples have a granodiorite to quartz diorite composition.

In outcrop the presence of well-formed hornblende crystals is commonly striking. Biotite is generally more abundant than hornblende (fig. 22), but is commonly altered; thus the fresher hormblende is more noticeable. The only rock with a marked predominance of hornblende is an unusual hybrid (specimen 488).

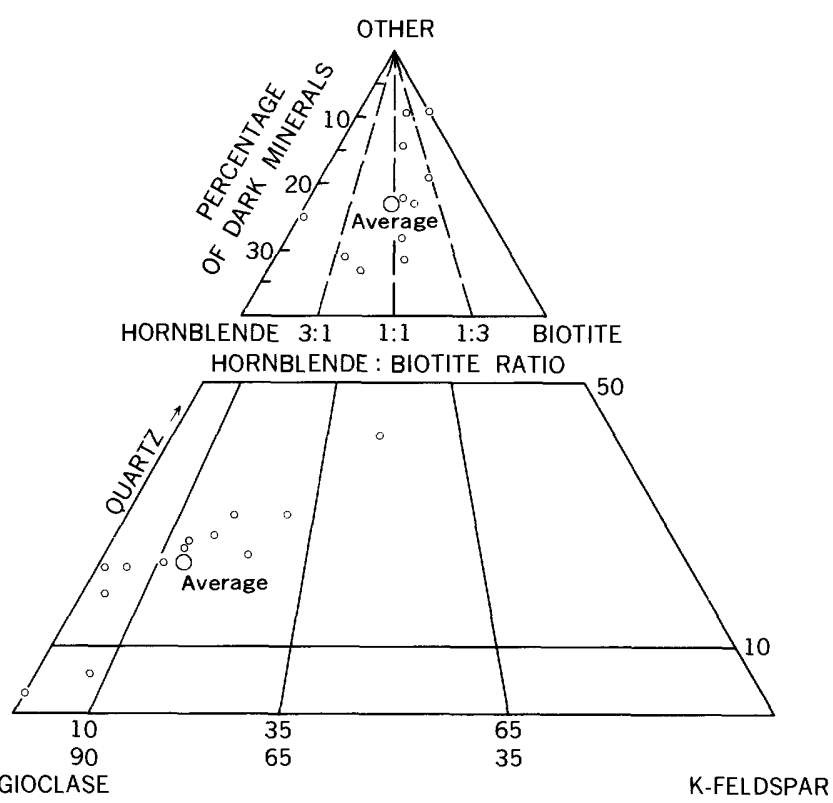

FIGURE 22.-Modal plot of gneiss of Bouquet Reservoir area.

TABLE 18.-Modes of gneiss of Bouquet Reservoir

\begin{tabular}{|c|c|c|c|c|c|c|c|c|c|}
\hline No. & $\begin{array}{l}\text { Plagio- } \\
\text { clase }\end{array}$ & $\begin{array}{l}\text { K- } \\
\text { feld- } \\
\text { spar }\end{array}$ & Quartz & $\begin{array}{l}\text { Bio- } \\
\text { tite }\end{array}$ & $\begin{array}{l}\text { Horn- } \\
\text { blende }\end{array}$ & Sphene & $\begin{array}{l}\text { Metal- } \\
\text { lic } \\
\text { opaque } \\
\text { min- } \\
\text { erals }\end{array}$ & Other & $\begin{array}{l}\text { Spe- } \\
\text { cific } \\
\text { gravity }\end{array}$ \\
\hline 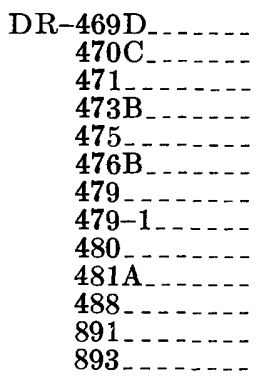 & $\begin{array}{l}54 \\
65 \\
49 \\
45 \\
54 \\
42 \\
57 \\
52 \\
51 \\
25 \\
62 \\
47 \\
55\end{array}$ & $\begin{array}{r}6 \\
\text { Trace } \\
8 \\
11 \\
12 \\
18 \\
2 \\
1 \\
3 \\
28 \\
5 \\
16 \\
8\end{array}$ & $\begin{array}{r}18 \\
2 \\
20 \\
24 \\
24 \\
26 \\
13 \\
15 \\
15 \\
38 \\
4 \\
20 \\
21\end{array}$ & $\begin{array}{r}12 \\
12 \\
14 \\
14 \\
6 \\
8 \\
15 \\
9 \\
17 \\
9 \\
<1\end{array}$ & $\begin{array}{r}10 \\
21 \\
9 \\
5 \\
3 \\
6 \\
13 \\
22 \\
14 \\
-25\end{array}$ & $\begin{array}{l}-\overline{1} \\
3\end{array}$ & 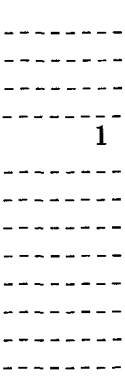 & $\begin{array}{c}1 \\
\\
\\
\\
\\
\end{array}$ & $\begin{array}{l}2.77 \\
2.89 \\
2.79 \\
2.73 \\
2.71 \\
2.71 \\
2.81 \\
2.79 \\
2.79 \\
2.67 \\
2.82 \\
2.73 \\
2.73\end{array}$ \\
\hline Average..... & 51 & 8 & 18 & 11 & 12 & 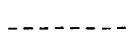 & 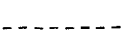 & & 2. 76 \\
\hline
\end{tabular}




\section{MICROSCOPIC DESCRIPTION}

The texture of these rocks is somewhat difficult to describe. Most can probably best be considered granoblastic, but some are more granitic (xenomorphic-granular). Most thin sections show strong foliation, and some have an incipient augen structure with quartz that is strongly shape oriented as well as intricately sutured, mosaitked, and woven around the more resistant feldspar grains. There are, however, gradations to much less strained and more homogeneous rocks.

Plagioclase makes up about half these rocks. It is well twinned and zoned and generally sodic to intermediate andesine, in part subhedral but more generally anhedral. It forms the more resistant crystals around which quartz and biotite are wrapped in the anastomosing augen rocks. Saussuritization is abundant in some rocks.

K-feldspar forms interstitial wisps and crystals except rarely where it has grown to poikilitic crystals up to $10 \mathrm{~mm}$ across. $\mathrm{K}$-feldspar, even in the interstitial crystals, seems to locally engulf other minerals.

Quartz is about as abundant in most of these rocks as it is in the unquestionably granitic rocks of this region. Although relatively abundant, it is mostly interstitial in extremely strained, shape-oriented trains of crystals. In this regard, its habit is certainly metamorphic, rather than granitic.

Biotite tends to be irregular, in shreds, and appears to wrap around resistant plagioclase. The brownish biotite is pleochroic from $\mathbf{X}=$ grayish yellow to grayish orange to $\mathrm{Z}=$ moderate brown to moderate reddish brown. The reddish tints are common. Chloritic alteration is widespread, and in some rocks all biotite is converted to chlorite. The greenish, smeared appearance of some hand specimens reflects this abundant alteration.

Green hornblende ranges from thin irregular shreds to euhedral crystals up to $10 \mathrm{~mm}$ long. Most hornblende crystals are relatively large and well formed; a few bent crystals are found in rocks with incipient augen structure. The larger hornblende crystals commonly include rounded and irregular quartz grains, and less commonly biotite and plagioclase. Hornblende is generally unaltered or has minor epidote or chlorite alteration in contrast to the much altered associated biotite. The hornblende appears to have recrystallized late and engulfed other constituents. The pleochroism is $\mathrm{X}=$ moderate greenish, $\mathrm{Y}=$ light olive, and $\mathrm{Z}=$ moderate yellowish green to grayish green.

Granitic-type accessory minerals-apatite, allanite, sphene, zircon, and metallic opaque minerals-are found in the specimens. In some specimens $(469 \mathrm{D}, 479,479-1$, 480) metallic opaque minerals are rare or absent, which seems unusual for rocks with abundant hornblende and biotite. Also, sphene is virtually absent in most of these same rocks; this is even more unusual because sphene is so common in the basement rocks of this region. Generally the accessory minerals look primary, but zircon commonly is rounded and may be largely inherited from the sedimentary (?) parent rocks of this gneissic complex.

\section{DISTINGUISHING FEATURES}

The relatively dark, foliated (but not gneissic) rocks of the belt from specimen 469 to specimen 480 (pl. 2) are somewhat distinctive, but hard to describe. The incipient augen structure, the distinctive hornblende crystals, and the smeared greenish foliation surfaces define a group of rocks that are structurally and texturally somewhere between the Wrightwood and Holcomb rocks. The Bouquet Reservoir rocks are darker and more foliated than the Holcomb rocks and contain much less well-banded gneiss than the Wrightwood rocks. Of course, further sampling in the Bouquet Reservoir area may modify this conclusion.

\section{GRANITIC ROCKS OF LIEBRE MOUNTAIN}

The mixed granitic and gneissic rocks of Liebre Mountain are exposed for about 20 miles along the south side of the San Andreas fault east of Gorman. These rocks were separated in mapping from the gneiss of Bouquet Reservoir by Dibblee $(1967, \mathrm{pl} .1$ ) because the Liebre is dominantly granitic, whereas the Bouquet Reservoir rocks are dominantly gneissic. It should be pointed out, however, that there is abundant gneissic material in the Liebre, and the distinction between the Liebre and Bouquet Reservoir units may be somewhat less than that shown by Dibblee (1967). Granitic rock does seem to dominate the west end of the Liebre area, but the relation of these rocks to the more gneissic rocks to the east is poorly known.

\section{SETTING AND GENERAL DESCRIPTION}

The granitic rocks, which dominate the west end of Liebre Mountain and are also associated with gneiss in the central part, are medium to light gray, medium grained, and mostly equigranular; they have an average composition of granodiorite. Intruding these rocks is a coarser, more felsic rock (specimen 632) that is much less abundant.

The granodiorite is foliated in part and locally contains schistose inclusions several feet long. Some foliation is accented by sheetlike concentrations of micaceous material in a somewhat homogeneous granitic matrix. This texture grades into concordant gneissic rocks. Ellipsoidal dioritic inclusions vary considerably in abundance-in one roadcut they are abundant, and a 
short distance away as few as one per 20 square feet are found. Dikes of dark fine-grained rock are also common locally in the granodiorite.

Modal analyses of these rocks are plotted in figure 23 and given in table 19. The overall spread and the average are rather close to the granodiorite of the Fairmont Reservoir, but the field is a little more scattered, particularly in quartz percentage. The dark mineral percentage and ratio are comparable.

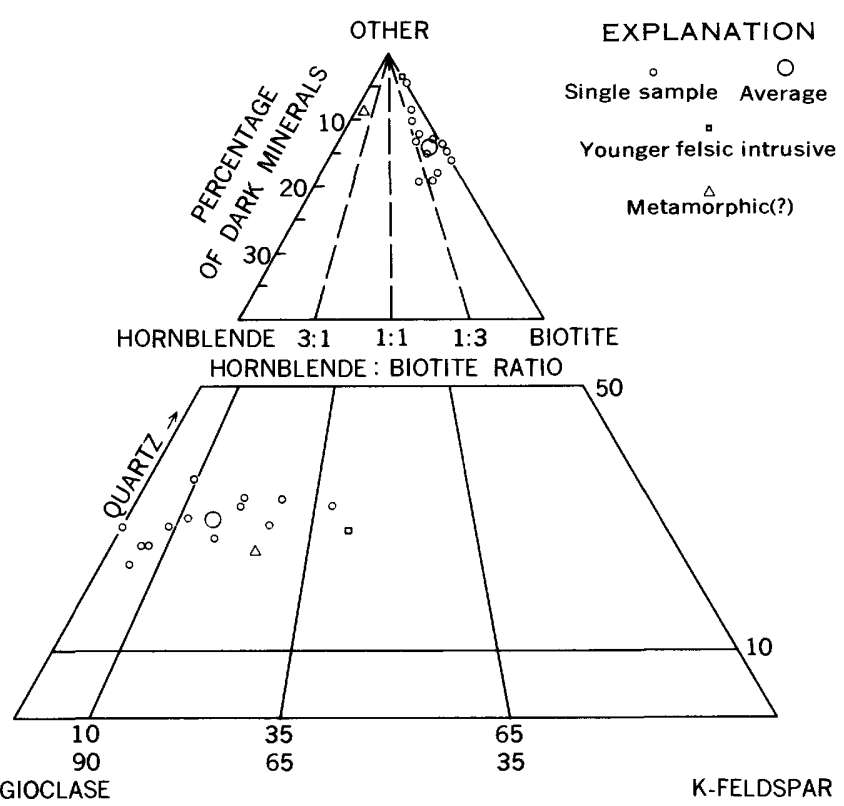

Figure 23.-Modal plot of granitic rocks of Liebre Mountain.

TABLE 19.-Modes of rocks of Liebre Mountain

[S $=$ sphene, $\mathbf{M e}=$ metallic opaque minerals, n.d. $=$ not determined]

\begin{tabular}{llll}
\hline No. & $\begin{array}{c}\text { Plagio- K-feld- Quartz } \\
\text { clase }\end{array} \underset{\text { spar }}{\substack{\text { Bio- } \\
\text { tite }}} \begin{array}{c}\text { Horn- } \\
\text { blende }\end{array}$ & Other & $\begin{array}{c}\text { Specific } \\
\text { gravity }\end{array}$ \\
\hline
\end{tabular}

\begin{tabular}{|c|c|c|c|c|c|c|}
\hline \multicolumn{7}{|c|}{ Granitic rocks } \\
\hline 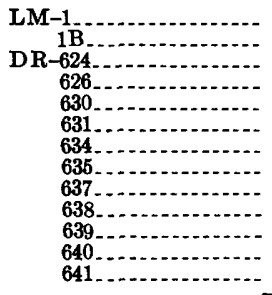 & $\begin{array}{l}40 \\
44 \\
52 \\
50 \\
60 \\
46 \\
46 \\
55 \\
57 \\
47 \\
57 \\
53 \\
59\end{array}$ & $\begin{array}{r}25 \\
17 \\
7 \\
5 \\
-17 \\
12 \\
5 \\
3 \\
12 \\
3 \\
11 \\
3\end{array}$ & $\begin{array}{l}31 \\
28 \\
25 \\
31 \\
25 \\
26 \\
28 \\
25 \\
21 \\
28 \\
21 \\
24 \\
19\end{array}$ & $\begin{array}{r}4 \\
9 \\
16 \\
14 \\
15 \\
8 \\
12 \\
12 \\
13 \\
10 \\
15 \\
10 \\
15\end{array}$ & 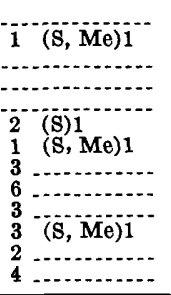 & $\begin{array}{l}2.66 \\
\text { n.d. } \\
2.70 \\
2.68 \\
2.72 \\
2.69 \\
2.66 \\
2.72 \\
2.73 \\
2.69 \\
2.72 \\
2.70 \\
2.73\end{array}$ \\
\hline Average. ......... & 51 & 9 & 26 & 12 & $2 \ldots$ & 2.70 \\
\hline \multicolumn{7}{|c|}{ Coarse felsic rock } \\
\hline
\end{tabular}

Metamorphic(?) rock

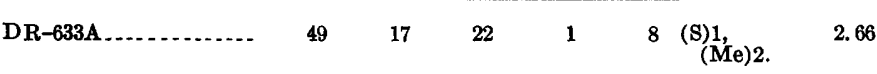

\section{MICROSCOPIC DESCRIPTION}

These rocks range from xenomorphic- to hypautomorphic-granular. Very locally they are seriate, but the large poikilitic $\mathrm{K}$-feldspar crystals are lacy and not as discrete as those in the Fairmont mass. The pinkish feldspar crystals of the Fairmont mass are readily visible in hand specimen, whereas those in the Liebre mass are obvious only on a selectively stained surface. Plagioclase is mostly fresh and cleanly twinned in these rocks. Also, oscillatory zoning is evident even in specimens associated with gneissic rocks and in some foliated rocks that may be partly homogenized gneisses. The plagioclase is andesine, mostly sodic. As already mentioned, $\mathrm{K}$-feldspar is characteristically interstitial, and even large crystals are weblike nets engulfing other minerals. Quartz is generally strongly mosaicked and sutured and in part seems to replace plagioclase. Biotite, the dominant dark mineral, is pleochroic from $\mathbf{X}=$ grayish yellow to grayish orange to $Z=$ moderate to dark yellowish brown and less commonly light to moderate olive brown. Hornblende is much less common than biotite and is absent in some specimens. It is pleochroic from $\mathrm{X}=$ moderate greenish yellow, to $\mathrm{Y}=$ light olive to dusky yellow green, to $Z=$ grayish green and less commonly moderate to dark yellowish green.

Sphene and magnetite are present in all specimens, but locally magnetite is rare. In some specimens sphene is euhedral and contains magnetite inclusions shaped like Arabic characters or in rounded blebs. In other specimens, magnetite and sphene are clustered together, and no magnetite is found in the sphene. Allanite (in part crusted with epidote), zircon, and apatite are also present. Alteration is uncommon in this rock, but the epidote that is present in small amounts probably is largely an alteration product. This is one difference between this mass and the epidote-bearing Fairmont Reservoir rocks.

\section{DISTINGUISHING FEATURES}

The granitic rocks at the west end of Liebre Mountain are not particularly distinctive. In part dark ellipsoidal inclusions are common; except for the presence of these inclusions, the Liebre rocks resemble the granodiorite of the Fairmont Reservoir, adjacent to Liebre Mountain on the north side of the San Andreas fault.

Despite the gross physical resemblance between the Liebre and Fairmont rocks, there do seem to be some differences, some of which are admittedly very subtle. $\mathrm{K}$-feldspar is dominantly interstitial in the Liebre rocks, whereas discrete pinkish $\mathrm{K}$-feldspar poikiloblasts are scattered through the Fairmont mass. Sphene and magnetite are abundant in both masses, but somewhat 
more so in the Fairmont mass. Also, in the Fairmont mass, the sphene is more commonly euhedral and contains more of the magnetite inclusions that are shaped like Arabic characters. Epidote is almost a characterizing accessory in the Fairmont rocks, whereas it is much less common in the Liebre rocks.

The Liebre rocks should also be compared with the granodiorite of Holcomb Ridge, for Dibblee (1968, p. 263) suggested that these two suites may be correlative. In physical appearance they are grossly similar, and the modal plot and mineral percentages are similar. Also, both the Holcomb and Liebre have associated foliated and gneissic rocks. Some Holcomb specimens also are unusual because of magnetite inclusions in sphene, but most do not have magnetite inclusions. In general, $\mathrm{K}$-feldspar and hornblende are more common in the Holcomb rocks, but their presence is not overly impressive.

It would be virtually impossible from the data at hand to separate the Holcomb, Fairmont, and Liebre masses with any degree of confidence. In other words, many granitic rocks look like other granitic rocks, and distinction or correlation should be approached very cautiously. It does seem worth suggesting, however, that three masses which are so similar could possibly belong to the same intrusive suite.

\section{GRANODIORITE OF THE LEBEC AREA}

\section{SETTING AND GENERAL DESCRIPTION}

The granodiorite of the Lebec area, a small part of which was named the Lebec Quartz Monzonite by Crowell $(1952$, p. $8-10)$, is exposed for a 20 -mile stretch, along the north side of the San Andreas fault and along the north side of the Garlock fault east of where it intersects the San Andreas. The granodiorite is believed to be thrust northward over gneissic rocks in the vicinity of Tejon Pass (Crowell, 1952, p. 8 and pl. 1). This thrust, which has been mapped eastward by Dibblee (oral commun., 1969) to where it intercepts the Garlock fault, marks the northern and eastern limit of the Lebec rocks. To the west the thrust relation is less certain, though the northern limit of Lebec rocks is fairly well known.

Most outcrops expose a light-gray rock liberally sprinkled with dark minerals, which tend to give the rocks a peppery appearance. The most distinctive handspecimen characteristic of these rocks is the brownish staining of some dark minerals. In thin section these crystals turn out to be iron-stained amphibole crystals that contain ghostlike clinopyroxene remnants. Although in most specimens dark minerals are small and irregular, some specimens contain scattered biotite books distinctly larger than the rest of the dark minerals. Most specimens are equigranular, but some have markedly poikilitic $K$-feldspar crystals as large as $15 \mathrm{~mm}$. These poikilitic crystals are not readily visible in field exposures, but require selective staining to make them obvious. Rounded quartz masses to $5 \mathrm{~mm}$ in diameter are distinctly darker than the light-gray feldspar and give a characteristic spotty appearance to many outcrops. Ovoid dioritic inclusions are small and rare. Roof pendants or inclusions are relatively abundant; marble is most common, and schist, hornfels, and quartzite are less common.

The modes of the Lebec rocks are given in table 20 and summarized in figure 24. The field is markedly elongate and shows a relatively constant quartz content as the feldspar ratio changes.

Coarse-grained felsic yellowish-weathering rocks are found locally in the Lebec outcrops. These alaskitic rocks may well be intrusive into the granodiorite, but no contact relations were seen. Crowell $(1952$, p. 9) noted a coarse-grained facies, having gradational but indistinct contacts with the dominant medium-grained gray rocks.

Fine-grained medium-gray rocks with very fine peppery dark minerals and scattered larger biotite books form small masses intrusive into metasedimentary rocks west of the main Lebec body. These rocks may be finegrained equivalents of the granodiorite of Lebec, but their modal plot (fig. 24) is somewhat different. Probably these fine-grained rocks are somewhat younger, more felsic derivatives of the granodiorite, as dikes of somewhat similar rocks intrude the granodiorite farther east.

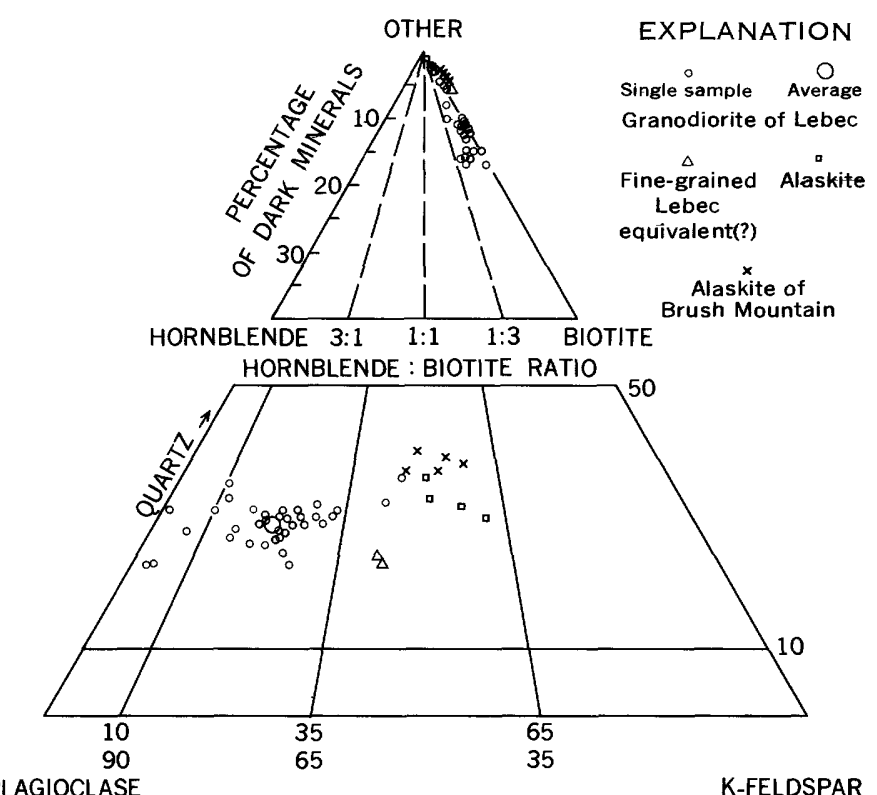

FIGURE 24.-Modal plot of the granodiorite and related rocks of the Lebec area. 
TABLE 20.-Modes of granodiorite and related masses of the Lebec area

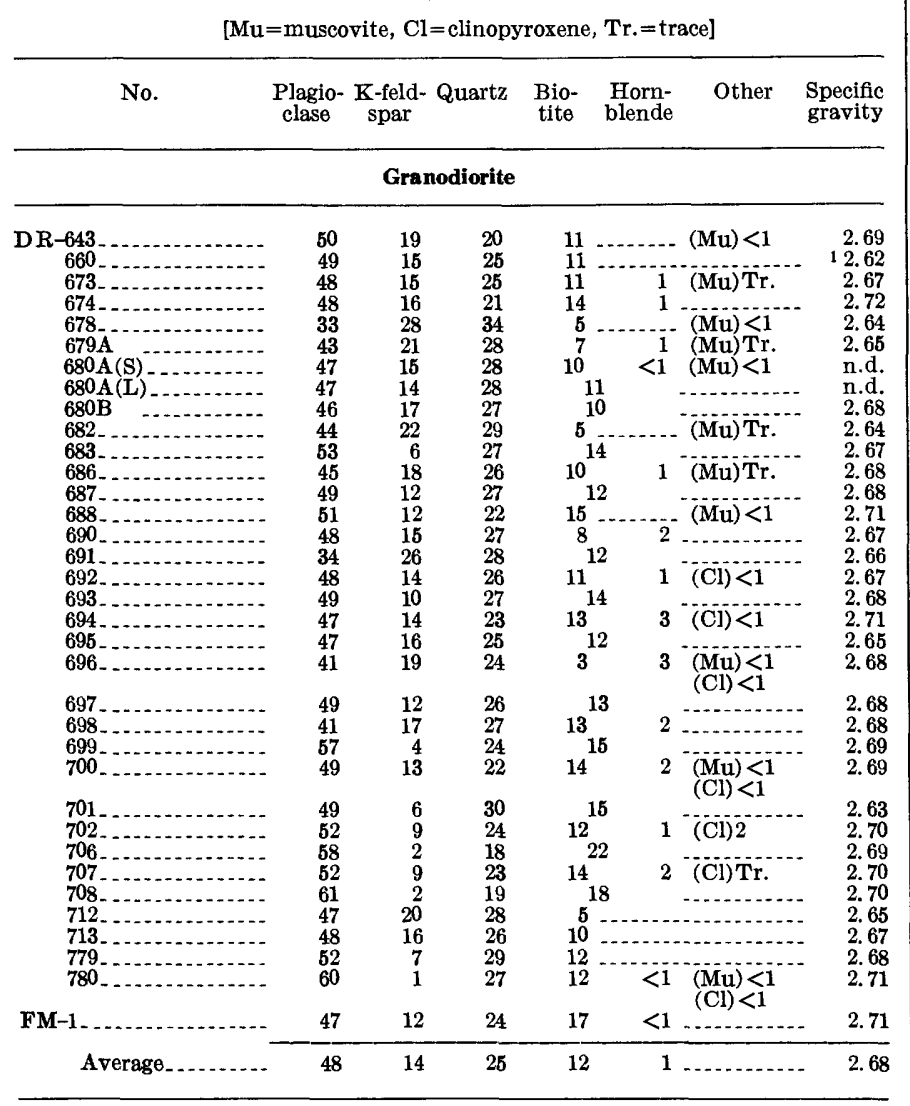

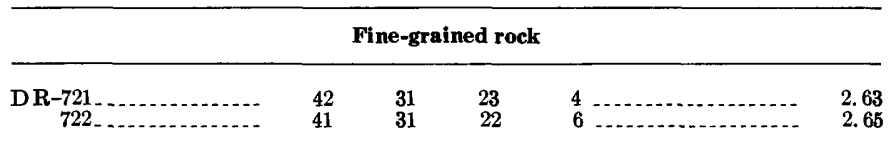

\begin{tabular}{|c|c|c|c|c|c|}
\hline \multicolumn{6}{|c|}{ Alaskite } \\
\hline $\begin{array}{r}\text { D R-646.... } \\
\quad 676 \\
\quad 681 \\
710\end{array}$ & $\begin{array}{r}29 \\
31 \\
27 \\
3\end{array}$ & $\begin{array}{l}38 \\
31 \\
42 \\
33\end{array}$ & $\begin{array}{l}31 \\
35 \\
30 \\
32\end{array}$ & $\begin{array}{l}2 \\
2 \\
3 \\
1 \\
1 \\
3\end{array}$ & $\begin{array}{l}2.59 \\
2.58 \\
2.60 \\
2.59\end{array}$ \\
\hline Average........... & 3 & 36 & 32 & $2 \ldots$ & 2.59 \\
\hline
\end{tabular}

\begin{tabular}{|c|c|c|c|c|c|}
\hline \multicolumn{6}{|c|}{ Alaskite of Brush Mountain } \\
\hline 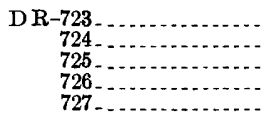 & $\begin{array}{l}30 \\
32 \\
25 \\
29 \\
27\end{array}$ & $\begin{array}{l}28 \\
28 \\
34 \\
32 \\
32\end{array}$ & $\begin{array}{l}39 . \\
35 \\
36 \\
36 \\
37\end{array}$ & 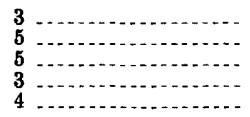 & $\begin{array}{l}2.62 \\
\text { 2. } 62 \\
2.62 \\
\text { 2. } 61 \\
\text { 2. } 62\end{array}$ \\
\hline Average.. & 29 & 31 & 36 & 4 & 2.62 \\
\hline
\end{tabular}

1 Weathered.

\section{MICROSCOPIC DESGRIPTION}

The granodiorite of the Lebec area is hypautomorphic-granular to seriate. Most is massive, but minor offects of shearing are evident in some thin sections. Plagioclase, the most abundant mineral, is cleanly twinned and oscillatorily zoned, mostly in the sodic andesine range. It is unaltered to impressively sericitized in places. K-feldspar ranges from trace amounts to nearly 30 percent of the rock. It is notably irregular and space filling, but it also engulfs all other constitutents and has grown to large lacy poikilitic crystals that have irregular to euhedral shapes. Quartz is interstitial and irregular, but in part forms rounded masses to $5 \mathrm{~mm}$ in diameter. Locally the quartz is strongly mosaicked, sutured, and even granulated, but most shows very little evidence of strain.

Biotite is in shreds and irregular grains; the larger books are also irregular. Pleochroic halos around very small crystals, presumably zircon, are common enough to be characteristic in this mass. Alteration is variable, but in some specimens almost all biotite has been converted to green chlorite, sparsely speckled with opaque grains. The biotite is strongly pleochroic from $\mathbf{X}=$ grayish orange to $Z=$ moderate reddish brown and much less commonly light to moderate brown. The dominant reddish-brown biotite helps to distinguish this mass from the Liebre, Fairmont, and Holcomb masses to the east which are grossly similar in modal composition.

Hornblende is a minor constitutent, but it is rather widespread. It is rarely in clean well-formed grains, but is spongy to lacy and mixed with biotite and the alteration products chlorite and calcite. Surprisingly, very little epidote is associated with these hornblende crystals. Perhaps the most distinctive feature of the hornblende crystals is the lacy colorless clinopyroxene cores that are stained with iron oxide, which accounts for the brownish-stained dark minerals that characterize outcrops of the Lebec rocks. The hornblende is pleochroic from $\mathrm{X}=$ moderate greenish yellow, to $\mathrm{Y}=$ light olive to light olive brown, to $Z=$ light olive to pale green. Much of the hornblende is very pale compared with other hornblende in the region.

Zircon, and possibly other highly birefringent, highrelief minerals, and apatite are common as inclusions in the biotite. Allanite is scattered in zoned, pleochroic grains that are reddish brown. Sphene is rare to fairly common, generally in irregular grains, and most frequently in biotite crystals as stringers and droplets. Opaque minerals are rare and are almost always associated with altered biotite. One specimen contains a little blue tourmaline.

The coarse-grained felsic yellowish-weathering alaskitic rocks in part have scattered rounded quartz grains that give a hint of aplitic texture. Coarse, patchy perthite in the $\mathrm{K}$-feldspar is also characteristic. The large masses of quartz show few signs of strain. Zircon is the only accessory mineral, and it is relatively abundant in biotite, with associated pleochroic halos. One specimen (DR-646) has a few grains of pink garnet. 


\section{DISTINGUISHING FEATURES}

The Lebec rocks are in part characterized by rounded gray quartz masses that make darker spots in an overall white to light-gray feldspar matrix. The scattered larger biotite books also contribute to a rather distinctive spotted look. On close observation of outcrops, however, the most characteristic feature of this mass is the scattered brown-stained dark minerals.

In thin section the most distinctive features of the Lebec rocks are reddish-brown biotite, reddish-brown allanite, very pale green hornblende, and the ghostlike iron-stained clinopyroxene cores in the hornblende crystals.

\section{ALASKITE OF BRUSH MOUNTAIN}

Coarse-grained felsic granitic rock (specimens 723727) crops out on the slopes of Brush Mountain, in the Eagle Rest Peak 71/2-minute quadrangle. It generally resembles the alaskitic rocks that possibly intrude the Lebec rocks farther to the east. The relation of the Brush Mountain rocks to the granodiorite of Lebec is not known. The rocks contain prominent pinkish- to salmon-colored K-feldspar and a fair sprinkling of biotite-perhaps too much to be classed as alaskites. Their microscopic texture suggests affinities with the alaskites to the east, however. Basically these rocks are xenomorphic-granular, but an "overprint" of rounded quartz grains gives an essentially aplitic appearance in thin section. The rounded quartz grains are particularly common in plagioclase, which is oligoclase in these rocks. Perthitic K-feldspar is also present. Quartz, which is present in large masses as well as in rounded "droplets," shows relatively little strain. Biotite is pleochroic in shades of yellow and brown and forms irregular-shaped crystals. The only accessory minerals are zircon, monazite, and a little apatite in biotite. The plagioclase contains a little sericite; otherwise, these rocks are virtually unaltered.

\section{GABBROIC ROGKS OF THE EAGLE REST PEAK AREA}

The westernmost outcrops of basement rock in the San Emigdio Mountains (pl. 2) are a suite of unusual gabbroic and related rocks that are separated from the much different granitic basement of the main San Emigdio basement by a cover of Tertiary rocks. These racks were studied by Hammond (1958), whose map was used for the area on plate 2 and as a base for sampling. The significance of these gabbroic rocks and their possible relation to the gabbros of Gold Hill and Logan were also discussed by Ross (1970). Three main rock types are exposed in the Eagle Rest Peak area; in presumed order of decreasing age they are (1) fine-grained metamorphosed igneous rocks with relic diabasic texture, (2) gabbro and pyroxenite, and (3) homblende quartz diorite-quartz gabbro.

The gabbro and pyroxenite make up about half the outcrop area. The gabbro consists of calcic plagioclase (labradorite-bytownite), pale somewhat fibrous amphibole, clinopyroxene, a little orthopyroxene, and metallic opaque minerals. Coarse exotic textures of these gabbros are very similar to those of the anorthositic gabbros of Gold Hill and Logan. The associated pyroxenite, which is locally abundant, is composed dominantly of various proportions of clinopyroxene and orthopyroxene.

The hornblende quartz diorite-quartz gabbro is the next most abundant rock type. These rocks are composed of about 50 percent plagioclase (andesine to labradorite), 30-35 percent green hormblende, and 20-25 percent quartz; a little biotite and metallic opaque minerals are also present. Modes of several of these specimens are summarized in figure 15 and given in table 21 . The plagioclase is generally less calcic than that in comparable rocks at Gold Hill and Logan, and quartz is also commonly more abundant. Nevertheless, the general physical and mineralogic character is similar to these other quartz gabbro outcrops.

The other major rock type at Eagle Rest Peak is a group of dark fine- to medium-grained generally foliated plagioclase-hornblende rocks that commonly have a diabasic texture. The mineralogical composition of these rocks, their texture, and a complete absence of associated pelitic or carbonate rocks suggest that they are metamorphosed igneous rocks, possibly originally a volcanic pile with associated diabase.

Table 21.-Modes of hornblende quartz diorite-quartz gabbro of Eagle Rest Peak locality $[\mathrm{B}=$ biotite, $\mathrm{Me}=$ metallic opaque minerals, $\mathbf{A l t}=$ alteration products, $\mathbf{M u}=$ muscovite,
$\mathbf{E}=$ epidote, $\mathrm{n} . \mathrm{d}=$ not determined $]$

\begin{tabular}{|c|c|c|c|c|}
\hline No. & $\begin{array}{c}\text { Plagio- } \\
\text { clase } \\
\text { (An max) }\end{array}$ & Quartz & $\begin{array}{l}\text { Horn- } \\
\text { blende }\end{array}$ & $\underset{\text { Specific }}{\text { gravity }}$ \\
\hline I-1(Hammond) & $44(75)$ & 22 & 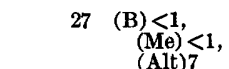 & n.d. \\
\hline DR-668 & 46 & 22 & $\begin{array}{l}23 \quad(\mathbf{B}) 3 \\
(\mathbf{M u}) 1 \\
(\mathbf{M e}) 1 \\
(\mathbf{E}) 4\end{array}$ & 2.82 \\
\hline $670 \mathrm{~A}$ & 52 & 13 & $32 \quad \begin{array}{c}\text { (B) } 1 \\
(\mathrm{Me}) 1 \\
(\mathrm{E}) 1\end{array}$ & 2.84 \\
\hline $1169 A$ & $57(70)$ & 5 & $37 \quad(\mathrm{Me}) 1$ & 2.95 \\
\hline $1169 \mathrm{~B}$ & 47 & 23 & $\begin{array}{l}\text { (B) } 23 \\
\text { (Me)1, } \\
\text { (Alt) } 4\end{array}$ & n.d. \\
\hline 1174-1(float) & $52(70)$ & 28 & 16 (B) 3 & 2.79 \\
\hline $\begin{array}{l}1180 \mathrm{~A} \\
1182 \mathrm{~A} \\
1182 \mathrm{~B} \\
1182 \mathrm{C} \\
1183\end{array}$ & $\begin{array}{l}52 \\
46(55) \\
44(75) \\
53(65) \\
46\end{array}$ & $\begin{array}{l}26 \\
24 \\
19 \\
19 \\
25\end{array}$ & $\begin{array}{ll}20 & (\mathrm{~B}) 2 \\
28 & (\mathrm{~B}) 2 \\
35 & (\mathrm{~B}) 2 \\
27 & (\mathrm{~B}) 1 \\
129 & \end{array}$ & $\begin{array}{l}2.78 \\
2.81 \\
2.85 \\
2.81 \\
2.78\end{array}$ \\
\hline Average . . . . . . & 49 & 20 & $\begin{array}{ll}26 & \text { (B) } 11 \\
\text { (Alt)3 }\end{array}$ & 2.82 \\
\hline
\end{tabular}

1 Intensely altered hornblende and biotite. 
In summary, these gabbroic and related rocks of the Eagle Rest Peak area have strong similarities to the gabbros of Gold Hill and Logan and marked dissimilarity to the granitic basement of the San Emigdio Mountains. As discussed by Ross (1970, p. 3659), these rocks may be representative of ophiolitic ocean crust.

\section{BASEMENT ROCKS OF THE MOUNT ABEL-MOUNT PINOS AREA}

A block of basement covers an area of about 60 square miles between the Big Pine and San Andreas faults. Though complex in detail, the gross pattern is relatively simple (pl.2). On the north side of the block is a faultbounded wedge of Pelona Schist. On the south are intrusive granodiorite and quartz monzonite. Between these, in the core of the block, is a complexly contorted mass of gneiss and migmatite and homogenized gneiss that has an almost igneous appearance. The Mount Abel-Mount Pinos block is the westernmost assemblage of basement rock of the Transverse Ranges on the south side of the San Andreas fault.

\section{HOMOGENIZED GNEISSIG ROGKS OF THE GENTRAL BLOCK}

A high-grade complex of banded gneiss, augen gneiss, migmatite, and amphibolite is characterized by widespread apparent gradation of metamorphic rocks into homogeneous granitic-looking rocks. This granitization or ultrametamorphism has produced a medium-gray quartz diorite to granodiorite that contains considerable accessory muscovite. Figure 25 and table 22 show the general modal range of these rocks.

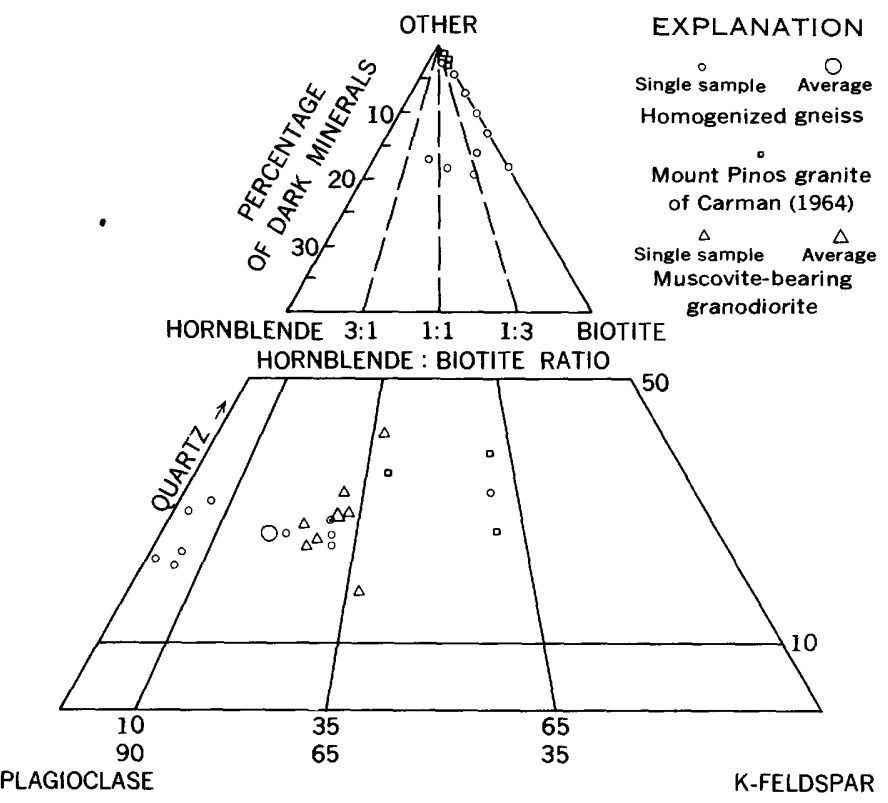

Frgure 25.-Modal plot of rocks in the Mount Abel-Mount Pinos area.
The texture of these rocks is largely granitic. Some are slightly porphyritic, others are somewhat aplitic. Well-formed cleanly twinned andesine that is weakly concentrically zoned in part emphasizes the igneous appearance of these rocks. $\mathbf{K}$-feldspar is commonly perthitic and in irregular grains. Much of the quartz is intricately sutured and mosaicked, and some is granulated and in slivery interstitial lenses. Myrmekite is common in these rocks.

TABLE 22.-Modes of basement rocks of the Mount Abel-Mount Pinos area

[ $\mathrm{Mu}=$ muscovite, $\mathrm{Me}_{\mathrm{e}}=$ metallic opaque minerals, $\mathrm{S}=$ sphene, $\mathbf{E}=$ epidote]

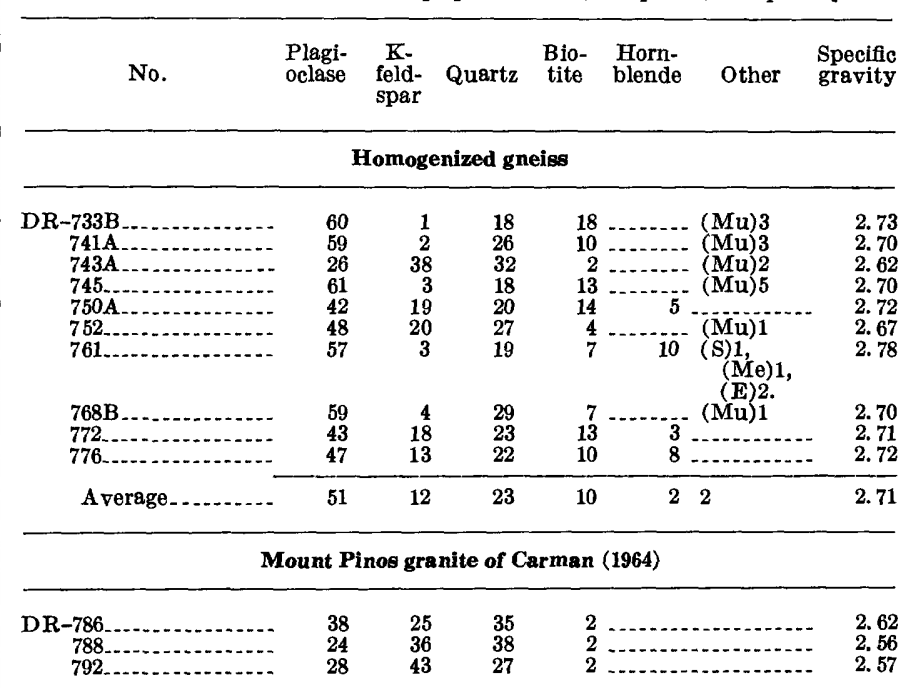

\begin{tabular}{|c|c|c|c|c|c|}
\hline \multicolumn{6}{|c|}{ Muscovite-bearing granodiorite } \\
\hline 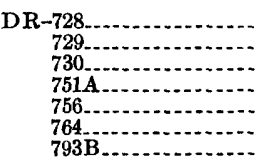 & $\begin{array}{l}50 \\
51 \\
53 \\
45 \\
45 \\
32 \\
51\end{array}$ & $\begin{array}{l}21 \\
29 \\
19 \\
23 \\
20 \\
20 \\
18\end{array}$ & $\begin{array}{l}25 \\
18 \\
24 \\
30 \\
32 \\
37 \\
27\end{array}$ & $\begin{array}{l}2 \\
2 \\
2 \\
2 \\
1 \\
1 \\
1 \\
1 \\
2\end{array}$ & $\begin{array}{r}2.62 \\
2.64 \\
2.62 \\
2.55\end{array}$ \\
\hline A verage............ & 47 & 21 & 28 & $1.5 \ldots \ldots .5$ & -......- \\
\hline
\end{tabular}

Biotite is generally the most abundant dark mineral and is the only dark mineral in some rocks. It occurs as irregular crystals that are pleochroic from $\mathrm{X}=$ grayish yellow to moderate yellow to $\mathrm{Z}=$ light to moderate olive brown. Hornblende is less abundant, but still common. Like the biotite, it occurs as irregular crystals; it is pleochroic as follows: $\mathbf{X}=$ moderate greenish yellow, $\mathrm{Y}=$ light olive, and $\mathrm{Z}=$ moderate to dark yellowish green. Muscovite makes up as much as 5 percent of these rocks. It is well scattered and surprisingly abundant for rocks of this composition.

The general granitic accessories are present: metallic opaque minerals, sphene, apatite, zircon, and allanite. Some euhedral sphene crystals are peppered with inclusions of metallic opaque minerals. The alteration products epidote, chlorite, and sericite are present in variable amounts. 
These rocks are widespread in the gneissic block from the west side of Mount Abel to the Mount Pinos Highway to the east. Though they vary in composition and texture, they have a generally similar appearance, which makes a regionally distinctive unit. The widespread occurrence of muscovite is also distinctive. In general setting, these rocks resemble the rocks of Red Hills, which seem to be homogenized gneisses also. The rocks of the Red Hills, however, do not contain muscovite.

\section{INTRUSIVE GRANITIG ROGKS OF THE SOUTH FLANK OF MOUNT ABEL-MOUNT PINOS}

A variety of rather felsic granitic rocks are exposed along the south flank of Mount Abel-Mount Pinos. These rocks are intrusive into the gneissic central block according to Lofgren (1967). In the part of this area that was studied by Carman (1964), the name Mount Pinos Granite was given these rocks; Carman (1964) recognized four granitic varieties. The limited data that I collected on this granite are recorded in table 22 and figure 25. The general range of composition is from alaskite to coarse-grained biotite quartz monzonite.

A rather distinctive granitic type is widespread along the south flank of Mount Abel-Mount Pinos; its relation to Carman's Mount Pinos Granite is not known. Lofgren $(1967$, p. 47 ) called it a two-mica leucogranodiorite and described it as fine grained and gneissic, with prominent biotite lineation. He noted that dikes of this rock up to 80 feet thick riddle the gneisses. I repeatedly found this rock, which I called muscovite-bearing granodiorite, in the Mount Abel-Mount Pinos area. It is a distinctive light-gray rock with an anastomosing fabric, peppered with small biotite and muscovite crystals. Mosaicked and sutured quartz is strongly shape orientated in thin sections, which, coupled with a sugary aplitic texture, makes a very distinctive rock. The plagioclase is generally oligoclase, but some is albite. Concentric oscillatory zoning is present. Myrmekite is also abundant in these rocks. The biotite is shredlike and pleochroic in yellow to brown. Modal analyses of several specimens of this rock are shown in figure 25 and table 22.

\section{PORPHYROBLASTIC GNEISS OF FRAZIER MOUNTAIN}

The basement rocks of Frazier Mountain cover a large area and are separated from the basement rocks of the Mount Abel-Mount Pinos area by the Big Pine fault. The most distinctive rock type of the Frazier Mountain block is coarsely porphyroblastic gneiss, which is rather widespread. I have seen no rocks like these elsewhere in the basement rocks of the Transverse and Coast Ranges.
The porphyroblasts are as large as $30 \mathrm{~mm}$ across, and the largest are invariably a mat of $\mathrm{K}$-feldspar crystals. Smaller porphyroblasts of plagioclase are also common. The porphyroblasts range from euhedral through a variety of shapes to ovoid lozenges in strongly foliated augen gneiss. The groundmass is a variety of micaceous quartzo-feldspathic material. Olive-brown to brown biotite is abundant in finely divided aggregates and sprinkled through the rocks. Muscovite and sericite are also abundant, as alteration of plagioclase as well as in fine-grained aggregates. All the Frazier Mountain rocks I examined contained abundant sericite.

Most of the gneissic rocks of Frazier Mountain are somewhat altered; granulation and other cataclastic effects are common, and the overall appearance is an irregularly oriented fabric of variable grain size. One surprising feature of these rocks is the apparent absence of amphibole. Carman (1964, p. 12-17) did not mention amphibole in his description of these rocks either.

\section{CONTRAST BETWEEN BASEMENT ROCKS OF THE MOUNT ABEL-MOUNT PINOS AND FRAZIER MOUNTAIN AREAS}

Carman (1964) suggested that the Mount PinosMount Abel basement rocks may be correlative with the Frazier Mountain basement rocks. However, these two adjacent basement suites have some notable differences. Perhaps most distinctive is that amphibole is absent in the Frazier Mountain gneisses, but common on Mount Abel and Mount Pinos. Also, sericitic alteration and muscovite aggregates are abundant on Frazier Mountain, whereas muscovite, though relatively common on Mount Abel-Mount Pinos, generally occurs as discrete grains in relatively fresh rocks.

The abundant coarse porphyroblastic rocks of Frazier Mountain are not present on Mount Abel and Mount Pinos. Mylonitic and cataclastic layers also seem more abundant on Frazier Mountain.

Neither the strongly foliated muscovite-bearing granodiorite nor the homogenized gneiss with granitic affinities that are so widespread on Mount Abel and Mount Pinos appear to be present on Frazier Mountain.

The internal structure of the two blocks is different too. On Mount Abel and Mount Pinos the general structural trend is northeast to easterly, whereas on Frazier Mountain the trend is northerly to northwesterly. These are very gross generalizations, however, for both areas have considerable structural complexity and are separated by a major fault zone. In conclusion, some very significant petrographic features contrast these two basement blocks, and thus I doubt that they are correlative. 
TEJON LOOKOUT GRANITE OF CROWELL (1952)

Crowell (1952, p. 10) described the Tejon Lookout Granite as "composed of five principal facies with minor variations." Exposures are very sparse, but I have observed three rock types in addition to aplitic rocks. Figure 26 and table 23 show modal analyses of these three: a hornblende-bearing granodiorite, a coarsegrained nondescript quartz monzonite, and a rock that apparently corresponds to one of Crowell's five facies. This third type, specimen 664, is a medium-grained rock with euhedral $\mathrm{K}$-feldspar phenocrysts as large as $20 \mathrm{~mm}$ and with abundant rounded quartz masses that look somewhat bluish. It has about the same amount of quartz and biotite as Crowell's rock but somewhat less K-feld-

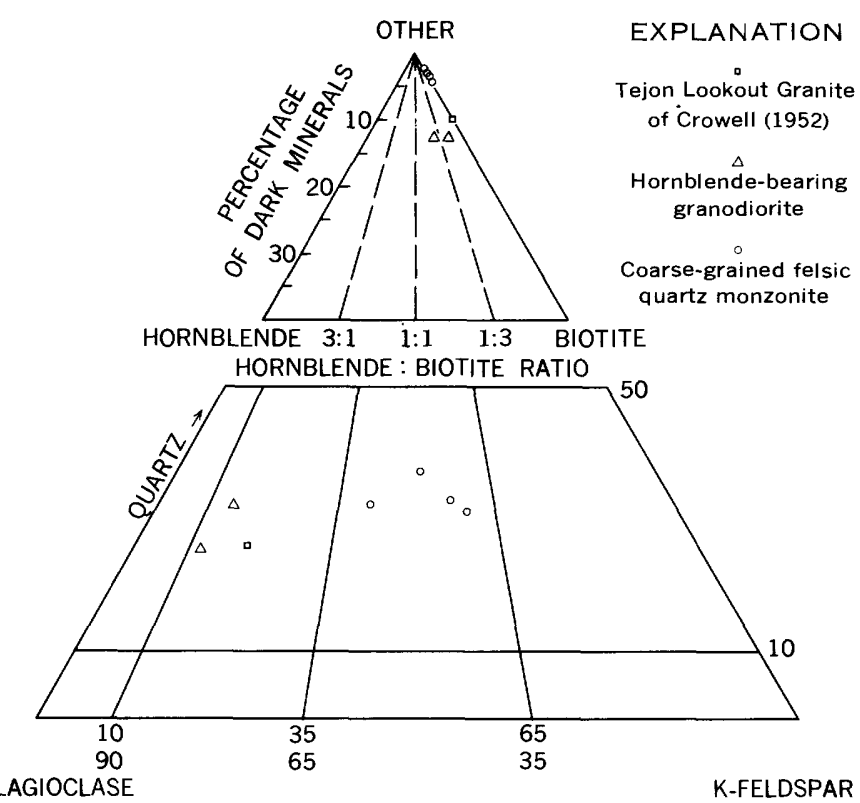

FIGURE 26.-Modal plot of rocks on Tejon Peak.

TABLE 23.-Modes of granitic rock on Tejon Peak

\begin{tabular}{|c|c|c|c|c|c|c|}
\hline No. & $\begin{array}{l}\text { Plagio- } \\
\text { clase }\end{array}$ & $\begin{array}{l}\text { K-feld- } \\
\text { spar }\end{array}$ & Quartz & Biotite & $\begin{array}{c}\text { Horn- } \\
\text { blende }\end{array}$ & $\begin{array}{l}\text { Specific } \\
\text { gravity }\end{array}$ \\
\hline \multicolumn{7}{|c|}{ Tejon Lookout Granite of Crowell (1952) } \\
\hline DR-664 & 53 & 14 & 23 & 10 & $\cdots$ & 2.61 \\
\hline \multicolumn{7}{|c|}{ Hornblende-bearing biotite granodiorite } \\
\hline $\begin{array}{r}\text { DR-662 } \\
663 \ldots \\
\end{array}$ & $\begin{array}{l}50 \\
57\end{array}$ & $\begin{array}{l}9 \\
8\end{array}$ & $\frac{28}{22}$ & $\begin{array}{l}10 \\
10\end{array}$ & $\mathbf{3}$ & $\begin{array}{l}2.68 \\
2.68\end{array}$ \\
\hline \multicolumn{7}{|c|}{ Coarse-grained felsic quartz monzorite } \\
\hline $\begin{array}{r}\text { DR-647 } \\
665 \\
666 \\
667 \mathrm{~B} \\
\end{array}$ & $\begin{array}{l}27 \\
30 \\
38 \\
28\end{array}$ & $\begin{array}{l}39 \\
31 \\
27 \\
36\end{array}$ & $\begin{array}{l}30 \\
36 \\
31 \\
32\end{array}$ & $\begin{array}{l}4 \\
3 \\
4 \\
4\end{array}$ & ( & $\begin{array}{l}2.59 \\
2.61 \\
2.64 \\
2.67\end{array}$ \\
\hline A verage & 31 & 33 & 32 & 4 & -............ & 2.63 \\
\hline
\end{tabular}

spar, perhaps because the large K-feldspar phenocrysts that Crowell reported are absent in the specimen described here.

\section{GRANODIORITE OF MUTAU AND PIRU CREEKS}

\section{SETTING AND GENERAL DESGRIPTION}

A relatively homogeneous fairly well exposed granitic mass crops out over several square miles north of Mutau Flat in the southern part of the Lockwood Valley $71 / 2$-minute quadrangle. The limits of the mass have not been determined.

In fresh outcrops, which are best along Piru Creek, the rock is medium light gray and liberally splashed with dark minerals. Small orange- to reddish-stained spots are characteristic. Ovoid dioritic inclusions are sparsely present; most are small, but some are as large as 8 inches across.

The modes (table 24; fig. 27) are tightly grouped, but these samples represent only a few square miles of a mass of undetermined size.

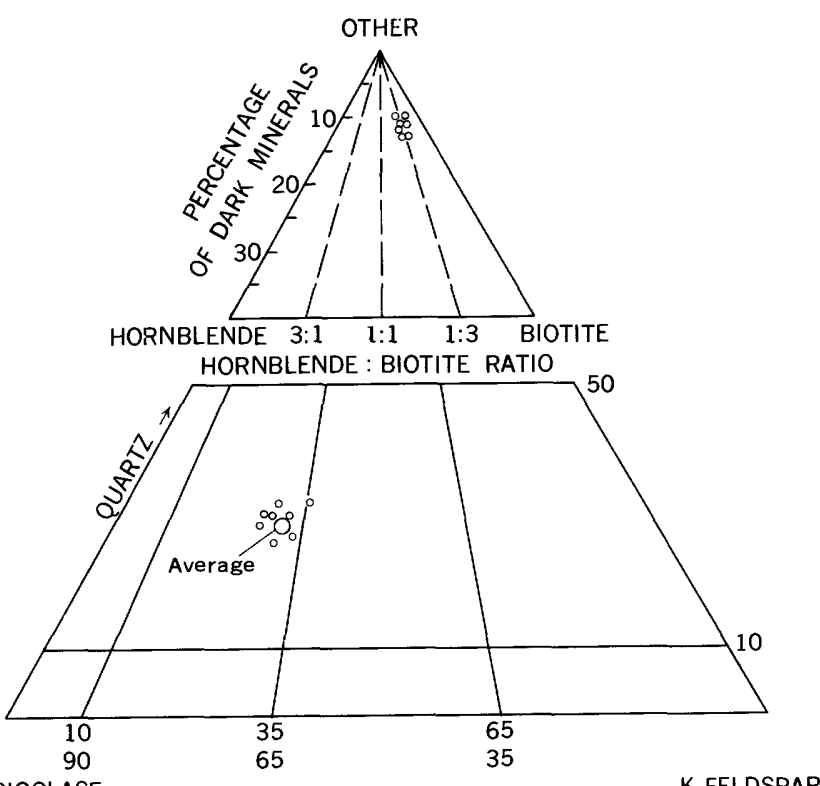

PLAGIOCLASE

K-FELDSPAR

FIGURE 27.-Modal plot of granodiorite of Mutau and Piru Creeks.

TABle 24.-Modes of granodiorite of Mutau and Piru Creeks

\begin{tabular}{|c|c|c|c|c|c|c|}
\hline No. & $\begin{array}{c}\text { Plagio- } \\
\text { clase }\end{array}$ & $\underset{\text { feldspar }}{\mathrm{K}-}$ & Quartz & Biotite & $\begin{array}{l}\text { Horn- } \\
\text { blende }\end{array}$ & $\begin{array}{l}\text { Specific } \\
\text { gravity }\end{array}$ \\
\hline $\begin{array}{r}\text { DR-805B. } \\
806 \\
807 \\
809 \\
810 \\
812 \\
813 \\
814\end{array}$ & $\begin{array}{l}44 \\
42 \\
45 \\
46 \\
45 \\
43 \\
44 \\
39\end{array}$ & $\begin{array}{l}17 \\
17 \\
17 \\
19 \\
18 \\
19 \\
22 \\
21\end{array}$ & $\begin{array}{l}26 \\
28 \\
25 \\
23 \\
27 \\
27 \\
24 \\
29\end{array}$ & $\begin{array}{r}10 \\
9 \\
9 \\
8 \\
8 \\
8 \\
7 \\
8\end{array}$ & $\begin{array}{r}3 \\
4 \\
4 \\
12 \quad 4 \\
2 \\
3 \\
3 \\
3\end{array}$ & $\begin{array}{l}2.69 \\
2.70 \\
2.68 \\
2.69 \\
2.67 \\
2.70 \\
2.69 \\
2.69\end{array}$ \\
\hline Average. & 43 & 19 & 26 & 9 & 3 & 2.69 \\
\hline
\end{tabular}




\section{MICROSCOPIC DESCRIPTION}

These rocks have a hypautomorphic-granular texture. Plagioclase is well formed, and some dark minerals are euhedral. Plagioclase is zoned through the range of sodic to intermediate andesine; oscillatory zoning is particularly evident. Many of the crystals are also composite. K-feldspar engulfs and corrodes other minerals, but individual grains are about the same size as the other constituents. Quartz forms irregular masses, some of which are as large as the feldspar crystals. Much quartz is strongly mosaicked, but some shows little strain. Myrmekite is common in these rocks too. The red-stained spots seen in hand specimen appear to be iron-stained spots in quartz, but no source for the staining is evident.

Biotite generally occurs as irregular crystals and is abundant. It is pleochroic from $\mathrm{X}=$ various pale shades of yellow and orange to $Z=$ moderate olive brown to dark yellowish brown. Some hornblende is euhedral, but most is present as irregular crystals, in part clustered with biotite. It is pleochroic as follows: $\mathrm{X}=$ moderate greenish yellow, $Y=$ light olive, and $Z=$ grayish green to moderate yellowish green.

Sphene, metallic opaque minerals, apatite, and zircon are found in all specimens. Some euhedral sphene crystals include small crystals of metallic opaque minerals. Alteration products are rare in these rocks.

\section{BASEMENT ROCKS OF THE MOJAVE DESERT IN THE LANCASTER-VICTORVILLE AREA}

Dibblee (1968, p. 261) stated that the heterogeneous basement of the Transverse Ranges is in marked contrast to the pre-Tertiary basement of the Mojave Desert to the north, which is mainly nonfoliated quartz monzonite. There is undoubtedly more granitic rock and less gneissic rock in the Mojave Desert than in the Transverse Ranges; however, the basement rocks of these two provinces may not be fundamentally different. Gneissic rocks, gabbroic rocks, and hybrid-looking granitic rocks are present north of the San Andreas fault zone, in the Mojave Desert-perhaps in greater abundance than was previously thought. One fact deserres emphasis: the San Andreas fault in this region is not a break between a gneissic and a granitic basement.

To test the homogeneity of the granitic basement rocks in the Mojave Desert, I sampled some masses in the Lancaster-Victorville area (pl. 2). A composite plot of the samples (fig. 28) shows a considerable range in composition. Most of the samples, however, plot as a relatively compact field that is dominantly granodiorite and less commonly quartz monzonite. Whether these samples are representative of the granitic rocks

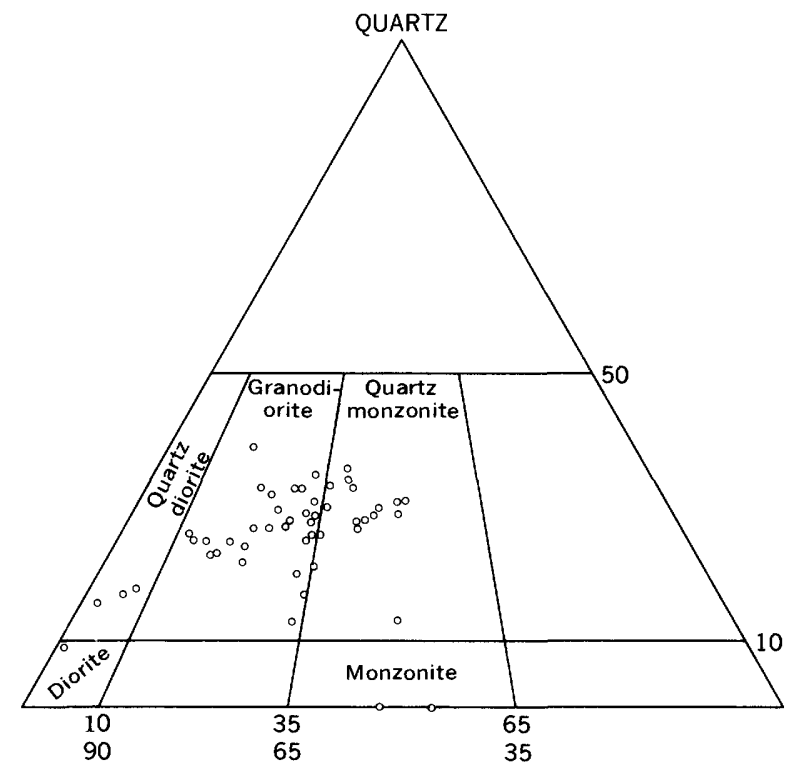

K-FELDSPAR

Figure 28.-Composite modal plots of selected granitic masses, Mojave Desert.

of the entire Mojave Desert region is, of course, a moot question. The following brief petrographic notes catalog some of the variation in the granitic rocks.

\section{GRANODIORITE OF LOVEJOY BUTTES}

\section{SETTING AND GENERAL DESGRIPTION}

Several buttes, the largest of which are the Lovejoy Buttes, rise out of the Mojave Desert northeast of Palmdale. They are composed principally of coarse-grained granitic rock. The isolated buttes definitely made up of this rock type cover an area of some 40 square miles, but similar rocks are much more widespread in the western Mojave Desert. Outcrops are extensive in the largely bare buttes, but most are deeply weathered and present the typical desert appearance of rounded, bouldery outcrop partially buried in grus; fresh specimens are difficult to obtain.

On fresh surfaces these rocks are light gray, but weathered surfaces are generally pale shades of yellow, orange, and brown. The texture ranges from coarsely equigranular to coarsely seriate with grayish-orange $\mathrm{K}$-feldspar crystals, as large as $40 \mathrm{~mm}$, that are notably poikilitic (some look almost like lacework).

Hardly any feature of these rocks can be termed distinctive. They do have a rather high quartz content (28 percent, table 25 ; fig. 29 ), and muscovite is present as a primary mineral. Also, the absence or rarity of metallic opaque minerals and sphene in some specimens may be a noteworthy characteristic. 


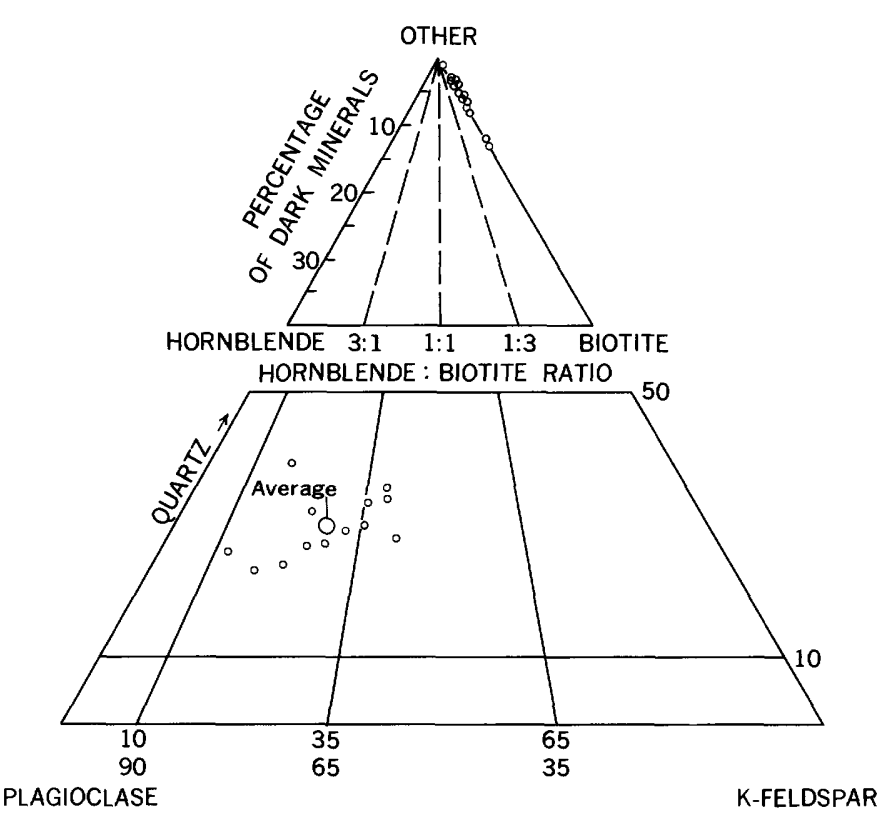

Figure 29.-Modal plot of granodiorite of Lovejoy Buttes.

TABLE 25.-Modes of granodiorite of Lovejoy Buttes

\begin{tabular}{|c|c|c|c|c|c|}
\hline No. & $\begin{array}{l}\text { Plagio- } \\
\text { clase }\end{array}$ & K-feldspar & Quartz & Biotite & $\begin{array}{l}\text { Specific } \\
\text { gravity }\end{array}$ \\
\hline $\begin{array}{r}\text { DR }-308 \\
\quad 315 \\
316 \mathrm{~A} \\
319 \mathrm{~A} \\
\mathbf{3 1 3} \\
913 \\
915 \\
916 \\
917 \\
918 \\
918 \\
921 \\
924 \\
925 \mathrm{~A} \\
926 \\
926\end{array}$ & $\begin{array}{l}45 \\
41 \\
47 \\
39 \\
38 \\
40 \\
55 \\
57 \\
42 \\
47 \\
50 \\
52 \\
56\end{array}$ & $\begin{array}{r}21 \\
23 \\
10 \\
25 \\
25 \\
29 \\
12 \\
8 \\
24 \\
16 \\
20 \\
18 \\
16\end{array}$ & $\begin{array}{l}27 \\
31 \\
37 \\
33 \\
36 \\
27 \\
20 \\
23 \\
28 \\
21 \\
26 \\
26 \\
23\end{array}$ & $\begin{array}{r}7 \\
5 \\
6 \\
3 \\
1 \\
4 \\
13 \\
12 \\
6 \\
8 \\
4 \\
4 \\
5\end{array}$ & $\begin{array}{l}2.63 \\
2.64 \\
2.66 \\
2.64 \\
2.61 \\
2.63 \\
2.70 \\
2.69 \\
2.63 \\
2.63 \\
2.65 \\
2.67 \\
2.67\end{array}$ \\
\hline Average......... & 47 & 19 & 28 & 6 & 2.64 \\
\hline
\end{tabular}

\section{MIGROSCOPIC DESGRIPTION}

The texture of these rocks is hypautomorphic-granular to seriate; crystals of plagioclase and biotite, in part, are well formed. Most specimens appear to have been considerably strained, for the quartz is intricately mosaicked and sutured. Some of the quartz appears to have been granulated and partly healed. Also, bent plagioclase twins and biotite books indicate that the rock has been deformed.

Plagioclase is generally sodic andesine; it is cleanly twinned and oscillatorily zoned and shows only minor sericitic alteration. The K-feldspar engulfs all the other major constituents of the rock and is in part gridtwinned, but it has no particularly distinguishing features. Quartz, as already mentioned, is abundant and typically intricately sutured and mosaicked.

Biotite ranges from well-formed books to irregular shreds. It is normally pleochroic from $\mathrm{X}=$ grayish orange to $\mathrm{Z}=$ moderate to grayish brown. Minor chloritic alteration is present. Muscovite is also present as a primary mineral in small amounts; it is commonly intergrown or clustered with the biotite.

Apatite and zircon are present in all specimens, and zircon is fairly abundant in a few. Sphene and metallic opaque minerals are less common and are absent in some specimens, particularly those containing abundant muscovite. The sphene also seems light colored in these rocks. Trace amounts of what is probably allanite are also present. This high-relief mineral is pleochroic from light olive brown to moderate to dark reddish brown and in this regard is somewhat different from allanite in other rocks of this region.

\section{GRANODIORITES OF HI VISTA AND ADOBE MOUNTAIN AND POSSIBLY RELATED HYBRID ROGKS OF BLACK MOUNTAIN}

\section{SETTING AND GENERAL DESGRIPTION}

North of the granodiorite of Lovejoy Buttes is a large area of granitic rock that is distinguished from the Lovejoy rocks by a higher percentage of dark minerals and the presence of hornblende. Though variable, these granodiorites of the Hi Vista-Adobe Mountain-Black Mountain area form a mappable group of rocks. The relation of these rocks to those at Lovejoy Buttes is not known, as the area between the two masses is covered by alluvium. The modal data for these rocks are given in table 26 and plotted in figure 30.
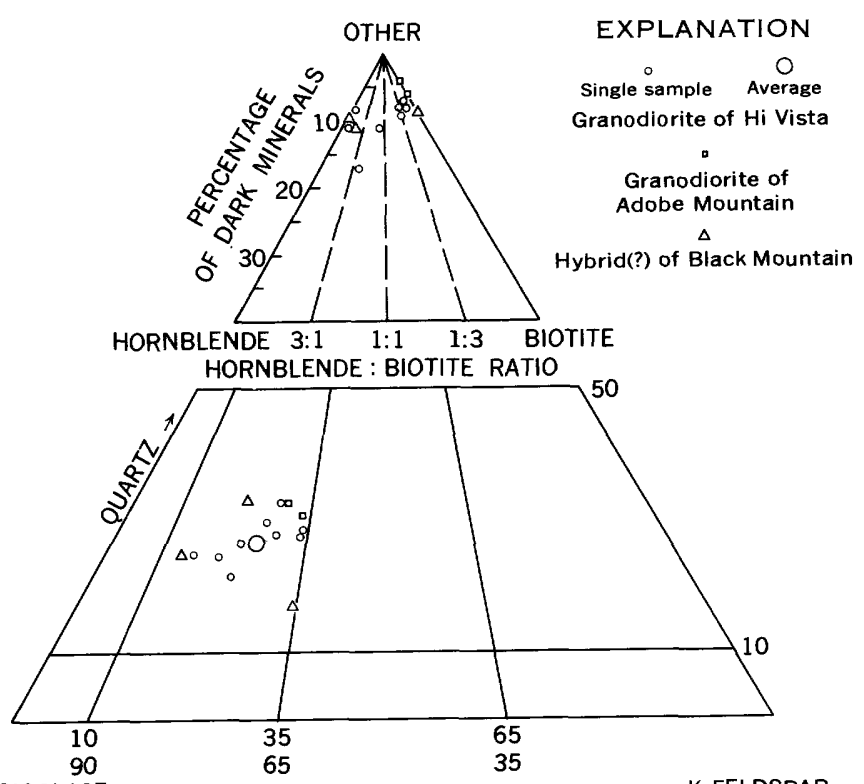

PLAGIOCLASE

K-FELDSPAR

Figure 30.-Modal plot of rocks of Hi Vista, Adobe Mountain, and Black Mountain. 
In the areas where the granodiorite is relatively homogeneous, it is light shades of gray and medium to coarse grained. The presence in most outcrops of visible hornblende, in part in crystals as long as $10 \mathrm{~mm}$, serves to identify this mass. Another characterizing feature of these granodiorites is the presence of scattered large biotite books. Outcrops range from equigranular to sparsely porphyritic or seriate. Throughout this area abundant aplite, alaskite, and simple pegmatite intrude the granodiorites.

TABLE 26.-Modes of rocks of Hi Vista, Adobe Mountain, and Black Mountain

[S = sphene, $\mathbf{M e}=$ metallic opaque minerals, $\mathrm{Clp}=$ clinopyroxene]

\begin{tabular}{|c|c|c|c|c|c|c|c|}
\hline No. & $\begin{array}{l}\text { Plagio- } \\
\text { clase }\end{array}$ & $\begin{array}{l}\text { K-feld- } \\
\text { spar }\end{array}$ & Quartz & Biotite & $\begin{array}{l}\text { Horn- } \\
\text { blende }\end{array}$ & Other & $\begin{array}{l}\text { Specific } \\
\text { gravity }\end{array}$ \\
\hline \multicolumn{8}{|c|}{ Granodiorite of Hi Vista } \\
\hline $\begin{array}{r}\text { DR-298. } \\
299 \\
321 \mathrm{~A}(\mathrm{gneissic}) \\
321 \mathrm{~B} \\
325 \text { (hybrid?) } \\
326 \\
328 \\
\end{array}$ & $\begin{array}{l}44 \\
47 \\
53 \\
51 \\
55 \\
48 \\
42\end{array}$ & $\begin{array}{l}22 \\
19 \\
16 \\
10 \\
14 \\
15 \\
18\end{array}$ & $\begin{array}{l}27 \\
26 \\
20 \\
20 \\
23 \\
23 \\
29\end{array}$ & $\begin{array}{r}6 \\
7 \\
1 \\
12 \\
<1 \\
114 \\
7\end{array}$ & $\begin{array}{r}1 \\
1 \\
10 \\
5 \\
8 \\
\hdashline 2\end{array}$ & (B) ${ }_{(\mathrm{M})}{ }^{1}$ & $\begin{array}{l}2.67 \\
2.67 \\
2.72 \\
2.73 \\
2.68 \\
2.65 \\
2.66\end{array}$ \\
\hline 329 & $\begin{array}{l}44 \\
44\end{array}$ & $\begin{array}{l}22 \\
17\end{array}$ & $\begin{array}{l}25 \\
26\end{array}$ & $\begin{array}{l}6 \\
6\end{array}$ & $\begin{array}{l}2 \\
5\end{array}$ & $\begin{array}{l}\text { (S, Me)1. } \\
\text { (S)1, } \\
\text { (Me) } 1\end{array}$ & $\begin{array}{l}2.67 \\
2.69\end{array}$ \\
\hline Average............ & 48 & 17 & 24 & 6 & 4 & $1 \ldots$ & 2.68 \\
\hline \multicolumn{8}{|c|}{ Granodiorite of Adobe Mountain } \\
\hline DR-294 & $\begin{array}{l}45 \\
43\end{array}$ & $\begin{array}{l}19 \\
22\end{array}$ & $\begin{array}{l}32 \\
29\end{array}$ & $\begin{array}{l}4 \\
6\end{array}$ & (n) & & $\begin{array}{l}2.65 \\
2.65\end{array}$ \\
\hline \multicolumn{8}{|c|}{ Hybrid of Black Mountain } \\
\hline DR-303 & $\begin{array}{l}47 \\
47\end{array}$ & $\begin{array}{l}14 \\
25\end{array}$ & $\begin{array}{l}30 \\
15\end{array}$ & 9 & 10 & (M) 1 (Me)1, & $\begin{array}{l}2.65 \\
2.66\end{array}$ \\
\hline $305 \mathrm{~A}$ & 56 & 9 & 22 & 1 & 10 & $(\mathrm{~s}, \mathrm{Me}) 2 .$. & 2.71 \\
\hline
\end{tabular}

1 Mostly chloritic alteration products.

Near the southeast limit of exposures, in the vicinity of Black Mountain, somewhat unusual granitic rocks are associated with metasedimentary rocks. They are unusual in that although they have about the same percentage of dark minerals as the other granodiorites, they have a highly variable hornblende-to-biotite ratio; some have virtually no biotite, abundant hornblende, and small amounts of clinopyroxene. Their close association with metamorphic rocks suggests that they are contaminated granitic rocks. Elsewhere along the south side of the area of exposure other gneissic and hybrid rocks are present in close and gradational association with normal granodiorite. A good sample of this local variation is in the quarry where sample 321 (table 26) was obtained; here the rocks grade from gneissic to a homogeneous granitics appearance.

The granodiorite of Adobe Mountain (the area near specimen locality 294) appears to be similar to the $\mathrm{Hi}$
Vista rocks, but there are some distinguishing features. Generally the Adobe Mountain rocks are somewhat finer grained and lack hornblende. The finer grained rocks appear to be separable from the Hi Vista rocks: they plot on the felsic edge of the general field of the granodiorite of Hi Vista and thus may be more differentiated and slightly younger than, but closely related to, the granodiorite of Hi Vista.

The hybrid(?) rocks of Black Mountain (area of specimen locality $303,304,305$ ), as well as specimen 325 and the gneissic specimen $321 \mathrm{~A}$, may all be part of a northwest-trending septum of metamorphic and contaminated granitic rocks between the granodiorites of Adobe Mountain-Hi Vista and those of Lovejoy Buttes. The general texture of these rocks is different, in that the dark minerals occur as irregular splotches rather than discrete crystals as are found in the other granodiorites. Also, in some of the hybrid(?) rocks, quartz seems less easy to distinguish from feldspar on weathered surfaces, yet it is just as abundant as in the other granodiorites. There is a messy, dirty look to these rocks in hand specimen that seems to contrast with typical uncontaminated granitic rocks.

\section{MICROSCOPIG DESGRIPTION}

The granodiorite of Hi Vista is generally hypautomorphic-granular with well-formed plagioclase and hornblende. In part it is weakly seriate to porphyritic with poikilitic K-feldspar crystals as large as $15 \mathrm{~mm}$. Another noteworthy textural feature is quartz in discrete grains as large as the average feldspar grains; it is not dominantly interstitial. The Adobe Mountain rocks have more lacy interstitial K-feldspar, though they also have phenocrysts are large as $20 \mathrm{~mm}$. Quartz in these rocks also ranges from interstitial grains in places to phenocrysts as large as $10 \mathrm{~mm}$ long, which are particularly noteworthy in these somewhat finer grained rocks. The Black Mountain rocks are generally xenomorphic-granular and have an irregular fabric. Dark minerals, particularly hornblende, are lacy and extremely irregular and splotchy. In all three rock types quartz exhibits little if any strain. Large, grossly mosaicked, or merely weakly undulatory extinguishing masses are most typical.

In all these rocks the plagioclase is sodic to intermediate andesine, which is cleanly twinned and oscillatorily zoned and has only minor sericitic aleration. $\mathrm{K}$-feldspar is similar to that in the other granitic rocks of the region; it ranges from interstitial traces to large poikilitic phenocrysts that engulf all the other minerals of the rock. Contacts of corroded plagioclase along the margins or included in the late engulfing $K$-feldspar crystals are in part marked by myrmekite zones. 
The quartz in these granodiorites has no distinctive features, but as already mentioned it does tend to range from interstitial small grains to crystals as large as 10 $\mathrm{mm}$ in the Adobe Mountain rocks. In general the quartz competes with the feldspar in grain size, and thus the crystallization of the quartz may have been concurrent, in large part, with crystallization of the feldspar.

Biotite occurs as scattered books as large as 3-5 $\mathrm{mm}$ across. From those well-formed crystals it ranges to shredlike irregular patches, and it has no particularly diagnostic features. Pleochroism is from $\mathrm{X}=$ grayish yellow and grayish orange to $\mathrm{Z}=$ moderate yellowish brown. All three rock types have essentially the same pleochroic formula, with some variation in shades of yellow and brown.

Hornblende ranges from sparse to abundant in the $\mathrm{Hi}$ Vista and Black Mountain rocks, but is absent from the Adobe Mountain rock. In some of the Hi Vista rocks it is subhedral to euhedral, but in the hybrid rocks it ranges from subhedral crystals to lacy irregular crystals and aggregates. In these rocks, small light-green clinopyroxene crystals are included in some hornblende crystals. The green hornblende is generally pleochroic from $\mathrm{X}=$ moderate greenish yellow, to $\mathrm{Y}=$ light olive, to $Z=$ moderate yellowish green, with some minor variation in shades of green. The hornblende pleochroism in the hybrid rocks is similar to that in the Hi Vista rocks.

Sphene and metallic opaque minerals (mostly magnetite) are the most common accessory minerals; some rocks contain nearly 1 percent of each. Euhedral sphene crystals include irregular metallic opaque grains in part, but this feature is not widespread. In some specimens sphene is free of metallic opaque minerals, although the two cluster together. In the hybrid rocks sphene is less commonly euhedral; the irregular crystals rarely include metallic opaque minerals, and in one specimen (303) sphene was absent. Apatite and zircon are present in nearly all specimens, but allanite was seen only in one.

\section{DISTINGUISHING FEATURES}

In hand specimen the well-formed shiny black biotite and hornblende crystals associated with discrete isolated quartz crystals probably constitute the most distinctive feature of the Hi Vista rock. Though all the granodiorites together form a somewhat heterogeneous grouping, they can be distinguished from other rocks in the immediate vicinity. It is doubtful, however, if these rocks are distinctive enough for regional correlationthey are too much like many other granodiorites. In thin section, also these rocks are not very distinctive. The virtual absence of allanite, a mineral otherwise seemingly common in granitic rocks of this region, might be an identifying feature.

\section{AUGITE MONZONITE OF GRANITE MOUNTAIN}

\section{SETTING AND GENERAL DESCRIPTION}

About 10 square miles of the west side of Granite Mountain is underlain by a distinctive foliated monzonite that weathers dusky brown to deep reddish brown and appears to be particularly susceptible to desert varnish. The foliation is primary and is produced principally by tabular K-feldspar crystals as long as $20 \mathrm{~mm}$ that give the rock a trachytic look. Elongate crystal aggregates of pyroxene and amphibole also contribute to the foliation. The foliation generally trends northwest and dips steeply southwest and seemingly parallels the presumed longest direction of the monzonite body.

Another distinctive feature of these rocks is that the dark minerals are stained brown by iron oxide alteration materials. The "trachytic" texture plus the distinctly brownish dark minerals make this rock very striking and quite different from other granitic rocks of the region.

Aplitic biotite quartz monzonite dikes intrude the augite monzonite along the south margin of the outcrop area. The relations of the light-colored quartz monzonite on each side of the somewhat elongate monzonite body are not known for certain, but admixtures of aplite, alaskite, and coarse-grained light-colored quartz monzonite in the northern part of the outcrop area suggest that the augite monzonite is part of an older terrane now engulfed and intruded by the lighter colored rocks.

The limited modal data from this body are shown in table 27. In general, plagioclase and K-feldspar are present in approximately equal amounts, and quartz is absent. There is more augite than hornblende in most specimens, but the ratio of augite to hornblende and total dark-mineral content vary greatly. One notable variant, a quartz-bearing hornblende monzonite, seems to be part of this same mass; it has no pyroxene (near specimen locality 247) but has fresh hornblende crystals as large as $10 \mathrm{~mm}$ long, in contrast with the generally altered iron-stained dark minerals in the rest of the mass.

\section{MICROSCOPIC DESCRIPTION}

The distinctive "trachytic" texture of hand specimen and outcrop is not readily obvious except where coarser $\mathrm{K}$-feldspar crystals are present in a thin section. The "groundmass" is generally xenomorphic-granular but in part looks almost granoblastic, partly because of incipient granulation and the development of some mortar structure. 
The plagioclase is oligoclase, on the basis of index of refraction and extinction angle. Much is surprisingly fresh and not saussuritized, considering the general appearance of outcrops. $\mathrm{K}$-feldspar is characteristically poikilitic and encloses the other constituents of the rocks, particularly plagioclase, which is in part concentrated along definite growth zones in the $\mathrm{K}$-feldspar. Grid-twinning is common, and some $\mathrm{K}$-feldspar is perthitic.

\begin{tabular}{|c|c|c|c|c|c|c|c|}
\hline No. & $\begin{array}{l}\text { K-feld- } \\
\text { spar }\end{array}$ & $\begin{array}{l}\text { Plagi } \\
\text { clase }\end{array}$ & blende & Augite & $\begin{array}{l}\text { Metallic } \\
\text { opaque } \\
\text { minerals }\end{array}$ & Sphene & Apatite \\
\hline DR-66-240A & 43 & & 9 & 4 & & & \\
\hline $\begin{array}{l}241 \mathrm{C}-. \\
243 \mathrm{~B}- \\
247 .- \\
253 \mathrm{~B}-\end{array}$ & 35 & 93 & 4 & $\begin{array}{r}21 \\
4 \\
7\end{array}$ & $\begin{array}{l}4 \\
7 \\
1 \\
1\end{array}$ & $\begin{array}{l}4 \\
2 \\
1\end{array}$ & rr. \\
\hline
\end{tabular}

Green hornblende is present in variable amounts, mostly as irregular crystals that are in part lacy. At least some of the hornblende is an alteration product of clinopyroxene. The hornblende is pleochroic from $\mathbf{X}=$ dusky yellow to moderate greenish yellow, to $\mathrm{Y}=$ dusky to dark yellowish green, to $Z=$ moderate green.

The clinopyroxene is pale green and somewhat pleochroic; in one specimen it has an index of refraction of $a \approx 1.695, \gamma \approx 1.722$, and is probably augite. The brown staining in hand specimen appears to result largely from abundant iron oxide alteration material that is associated with clusters of augite, green hornblende, magnetite, and sphene.

Metallic opaque crystals (chiefly magnetite) and sphene make up as much as several percent each of these rocks. Apatite is widespread but less abundant, and allanite is rare.

\section{DISTINGUISHING FEATURES}

The somewhat dark, reddish-brown outcrops of the augite monzonite, commonly desert varnished, coupled with the coarsely "trachytic" texture shown by tabular $\mathrm{K}$-feldspar crystals, are distinctive features of this unit. The unit may well be unique in this region. The brown altered augite crystals are also notable in many outcrops.

The mineralogical makeup of this rock is also quite atypical in this region. On fresh surfaces the rock appears felsic, but it is almost entirely devoid of quartz and contains no biotite; generally augite (much altered) exceeds hornblende (relatively fresh); the plagioclase is sodic (oligoclase). The features characterize a rock that should be easily recognizable in the clasts of younger fragmental rocks. The general appearance and setting of the augite monzonite suggest that it is an older, possibly hybrid rock engulfed in younger quartzose granitic rocks.

\section{MISCELLANEOUS GRANITIC ROCKS OF THE MOJAVE REGION}

\section{GRANODIORITE OF VICTORVILLE}

Just northwest of Victorville, a medium-grained granitic rock with distinctive brown-stained quartz is exposed in fresh roadcuts. This rock has a peppery texture and contains sparse hornblende and as much as 8 percent biotite. Oscillatorily zoned cleanly twinned plagioclase, lacy interstitial $\mathbf{K}$-feldspar, and small interstitial weakly strained quartz masses form the bulk of the rock. Small biotite flakes are pleochroic from $X=$ moderate yellow to $Z=$ light olive. Green hornblende is pleochroic from $\mathbf{X}=$ moderate greenish yellow, to $\mathbf{Y}=$ light olive, to $Z=$ moderate yellowish green.

One of the characteristic features of this rock is the abundance of euhedral sphene crystals, which are literally peppered with metallic opaque inclusions. Allanite, zircon, and apatite are also present.

Specimen 281 (table 28; fig. 31) is quite different from the other specimens and appears to be part of an alaskitic mass. It is associated with banded aplite and alaskite.

\section{QUARTZ MONZONITE OF THE MOJAVE RIVER AND MISCELLANEOUS GRANITIC ROCKS}

Coarse-grained generally felsic and nondescript quartz monzonite is exposed along the Mojave River east of Hesperia, and similar rocks are found to the northeast, near Rattlesnake pluton (MacColl, 1964, p. 805). Salmon-pink K-feldspar is common. Grains of metallic opaque minerals are rather abundant. Figure 31 and table 28 give the general modal picture of this rock.

\section{GRANODIORITE OF BELL MOUNTAIN AND MISGELLANEOUS DARK HYBRID(?) ROCKS}

Medium- to dark-gray granodiorite on Bell Mountain is in marked contrast to the surrounding felsic rocks. The presence of metavolcanic rocks on Bell Mountain and the abundance of metavolcanic inclusions suggest that the dull color of this rock is due to contamination. 

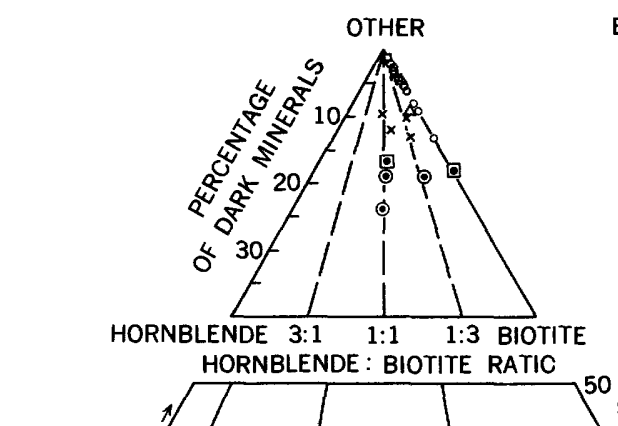

EXPLANATION

Quartz monzonite of Mojave River

Quartz monzonite of Dibblee (1967)

Granodiorite of Victorville

Granódiorite of Bell Mountain

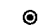

50 Shadow Mountains hybrid(?)

(1)

Miscellaneous hybrid(?)

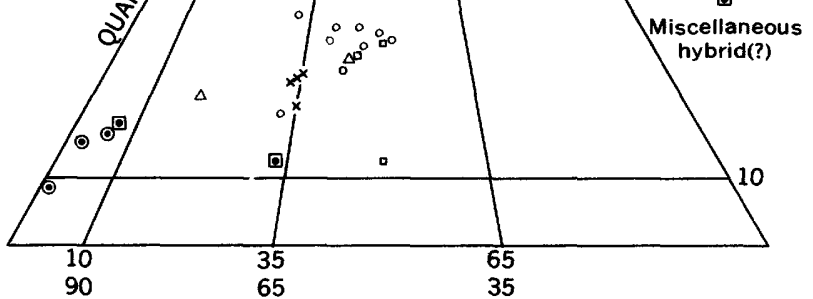

PLAGIOCLASE

K-FELDSPAR

Fraure 31.-Modal plot of miscellaneous granitic rocks in the Mojave Desert.

TABLE 28.-Modes of miscellaneous granitic rocks of the Mojave Desert

[S = sphene, Me=metallic opaque minerals $]$

\begin{tabular}{|c|c|c|c|c|c|c|c|}
\hline No. & $\begin{array}{c}\text { Plagio- } \\
\text { clase }\end{array}$ & $\underset{\text { spar }}{\text { K-feld- }}$ & Quartz & Biotite & $\begin{array}{l}\text { Horn- } \\
\text { blende }\end{array}$ & Other & $\begin{array}{l}\text { Specific } \\
\text { gravity }\end{array}$ \\
\hline \multicolumn{8}{|c|}{ Quartz monzonite of the Mojave Fiver } \\
\hline 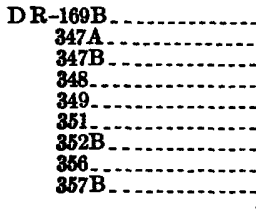 & $\begin{array}{l}34 \\
36 \\
33 \\
39 \\
37 \\
40 \\
41 \\
49 \\
32\end{array}$ & $\begin{array}{l}28 \\
23 \\
32 \\
27 \\
31 \\
30 \\
20 \\
24 \\
33\end{array}$ & $\begin{array}{r}30 \\
27 \\
.31 \\
32 \\
29 \\
26 \\
33 \\
18 \\
29\end{array}$ & $\begin{array}{r}8 \\
13 \\
4 \\
2 \\
3 \\
4 \\
6 \\
9 \\
6\end{array}$ & $\begin{array}{l}2 \\
\cdots\end{array}$ & $\left(\overline{\mathrm{S}}, \mathrm{M}_{\mathrm{e}}\right) \mathrm{i}^{-}$ & $\begin{array}{l}2.65 \\
2.68 \\
2.64 \\
2.63 \\
2.63 \\
2.62 \\
2.64 \\
2.66 \\
2.63\end{array}$ \\
\hline Average. . & 38 & 28 & 28 & 6 & - & & $\overline{2.64}$ \\
\hline
\end{tabular}

Miscellaneous quartz monzonite 1

\begin{tabular}{|c|c|c|c|c|c|}
\hline $\begin{array}{r}\text { DR-245B } \\
\text { 264A } \\
286 \\
\end{array}$ & $\begin{array}{l}\mathbf{4 4} \\
\mathbf{3 3} \\
\mathbf{3 7}\end{array}$ & $\begin{array}{l}\mathbf{4 3} \\
\mathbf{3 3} \\
\mathbf{3 0}\end{array}$ & $\begin{array}{l}12 \\
30 \\
28\end{array}$ & $\begin{array}{l}1 \\
4 \\
5\end{array}$ & $\begin{array}{l}2.68 \\
2.66 \\
2.62\end{array}$ \\
\hline
\end{tabular}

\begin{tabular}{|c|c|c|c|c|c|c|}
\hline \multirow[b]{2}{*}{ DR-280 } & \multicolumn{6}{|c|}{ Granodiorite of Vietorville } \\
\hline & $\begin{array}{l}56 \\
39\end{array}$ & $\begin{array}{l}13 \\
\mathbf{3 0}\end{array}$ & $\begin{array}{l}20 \\
27\end{array}$ & $\begin{array}{l}8 \\
4\end{array}$ & $1(\mathbf{S}) 1,(\mathrm{Me}) 1$ & $\begin{array}{l}2.69 \\
2.66\end{array}$ \\
\hline
\end{tabular}

\begin{tabular}{|c|c|c|c|c|c|c|}
\hline \multicolumn{7}{|c|}{ Granodlorite of Bell Mountain } \\
\hline $\begin{array}{r}\text { DR-271 } \\
\text { 273B } \\
273 \mathrm{C} \\
274 \mathrm{D}\end{array}$ & $\begin{array}{l}44 \\
45 \\
43 \\
43\end{array}$ & $\begin{array}{l}23 \\
24 \\
22 \\
23\end{array}$ & $\begin{array}{l}23 \\
19 \\
22 \\
23\end{array}$ & $\begin{array}{r}8 \\
7 \\
10 \\
5\end{array}$ & $\begin{array}{lll}2 & & \\
5 & \\
3 & (\mathrm{Me}) 1\end{array}$ & $\begin{array}{l}2.68 \\
2.71 \\
2.71 \\
2.71\end{array}$ \\
\hline
\end{tabular}

\begin{tabular}{|c|c|c|c|c|c|c|}
\hline $\begin{array}{r}\text { DR-288 } \\
\quad 289 \\
\quad 292 \mathrm{~B} \\
\end{array}$ & $\begin{array}{l}62 \\
63 \\
73\end{array}$ & $\begin{array}{l}2 \\
4 \\
1\end{array}$ & $\begin{array}{r}12 \\
14 \\
7\end{array}$ & $\begin{array}{l}12 \\
10 \\
16\end{array}$ & $\begin{array}{r}12 \\
9 \\
4\end{array}$ & $\begin{array}{l}2.76 \\
2.78 \\
2.74\end{array}$ \\
\hline
\end{tabular}

Miscellaneous dark hybrld(?) rocks

\begin{tabular}{|c|c|c|c|c|c|}
\hline DR-355B & $\begin{array}{l}62 \\
48\end{array}$ & $\underset{24}{5}$ & $\begin{array}{l}16 \\
11\end{array}$ & 18 - 8 & $\begin{array}{l}2.72 \\
2.70\end{array}$ \\
\hline
\end{tabular}

1 Specimens from unit that Dibblee (1967, pl. 1) mapped as quartz monzonite in the Mojave Desert.
Thin sections of these rocks have the generally messy appearance that might be predicted from hand specimens. The dark minerals are clustered, shredded, and irregular, and the rock is commonly altered and fractured. Although both biotite and hornblende have fairly standard pleochroic colors, both tend to be pale; this may be partly due to alteration. The plagioclase ranges from sodic andesine to sodic labradorite. Metallic opaque minerals are abundant.

In the Shadow Mountains and at Ord Mountain are some dark dull hybrid(?) rocks that may also be contaminated (fig. 31; table 28). The rocks of the Shadow Mountains, however, look rather clean in thin section. Plagioclase occurs as well-formed, well-twinned, oscillatorily zoned crystals (andesine). Both quartz and $\mathrm{K}$-feldspar are interstitial. Biotite is pleochroic from $\mathrm{X}=$ grayish yellow to $\mathrm{Z}=$ light olive brown. Hornblende is pleochroic from $\mathrm{X}=$ moderate greenish yellow, to $\mathrm{Y}=$ light olive, to $\mathrm{Z}=$ grayish green. Metallic opaque minerals, sphene, apatite, and zircon are present as accessories.

\section{CHEMICAL GHARACTERISTICS}

Chemical analyses of 97 specimens from the three regions covered in this report are tabulated in tables 29-31. Of these, 84 are new analyses. These tables also list semiquantitative spectrographic analyses of minor elements, CIPW norms, Niggli numbers, modes, and specific gravity. These data tables form the basis for the 13 diagrams that follow and are used for comparisons with the Sierra Nevada and southern California batholiths. Data from the Sierra Nevada batholith have been divided rather arbitrarily into two categories: (1) western Sierra Nevada (consisting of granitic bodies in the western foothills belt), and (2) eastern Sierra Nevada (which includes the chemical data from the central and eastern Sierra Nevada). Analyses that were used from the western Sierra Nevada include those published by Turner (1894), Hietanen (1951), Best (1963), and Putnam and Alfors (1965), as well as unpublished analyses furnished to me by L. D. Clark and F. C. W. Dodge. Analyses from the eastern Sierra Nevada include those published by Pabst (1928), Loomis (1963), Moore (1963), Rinehart and Ross (1964), Bateman (1965), and Ross (1969), as well as unpublished analyses furnished to me by P. C. Bateman, F. C. W. Dodge, R. B. Fournier, N. K. Huber, and D. L. Peck. The southern California batholith analyses are from Larsen (1948). 
TABLE 29.-Chemical data on basement

[Chemical anaiyses by P. L. D. Elmore, Lowell Artis, S. D. Botts, Gillison Chloe, J. L. Glenn, James Kelsey, and Hezekiah Smith. Semiquantitative spectrographic analyses 0.12 , etc., but are reported arbitrarily as midpoints of these brackets, $1 ., 0.7,0.5,0.3,0.2,0.15,0.1$, etc. The precision of a reported value is approximately plus or minus one

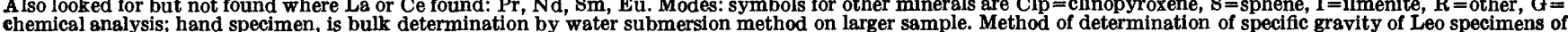

\begin{tabular}{llllllll}
\hline & \multicolumn{3}{c}{ Bodega Head } & \multicolumn{2}{c}{ Point Reyes } \\
\cline { 2 - 5 } & DR-511A & DR-510 & DR-605 & BID-19 & BID-10 & DR-526 & DR-525 \\
\hline
\end{tabular}

Chemical analyses (weight percent)

\begin{tabular}{|c|c|c|c|c|c|c|c|}
\hline 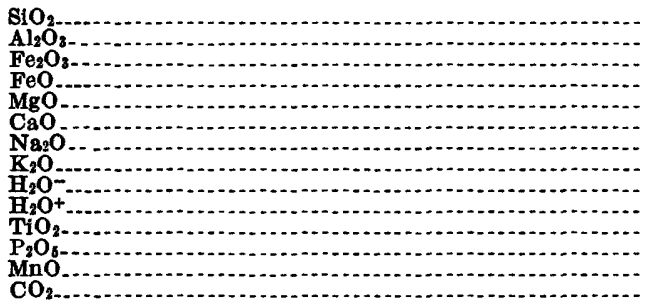 & $\begin{array}{r}60.2 \\
17.7 \\
1.5 \\
4.6 \\
3.5 \\
5.8 \\
3.5 \\
1.6 \\
.21 \\
1.1 \\
.89 \\
.24 \\
<.05 \\
<.05\end{array}$ & $\begin{array}{r}60.7 \\
17.0 \\
1.5 \\
4.7 \\
3.6 \\
5.5 \\
3.1 \\
1.8 \\
.20 \\
1.2 \\
.89 \\
.24 \\
.10 \\
.08\end{array}$ & $\begin{array}{l}63.2 \\
15.8 \\
.80 \\
4.0 \\
2.9 \\
4.2 \\
3.0 \\
2.7 \\
.34 \\
1.7 \\
.91 \\
.16 \\
.09 \\
<.05\end{array}$ & $\begin{array}{r}58.44 \\
17.06 \\
1.36 \\
5.06 \\
2.96 \\
5.82 \\
3.40 \\
2.84 \\
.38 \\
2.12 \\
.15 \\
1.41 \\
\text { n.d0 } \\
\text { n.d. }\end{array}$ & $\begin{array}{r}63.12 \\
16.13 \\
3.53 \\
3.65 \\
1.86 \\
5.04 \\
2.78 \\
1.08 \\
.97 \\
.93 \\
\text { Trace } \\
.39 \\
.38 \\
\text { n.d. }\end{array}$ & $\begin{array}{c}64.0 \\
17.5 \\
.95 \\
3.5 \\
2.0 \\
4.5 \\
3.7 \\
1.8 \\
.25 \\
1.1 \\
.39 \\
.24 \\
.07 \\
<.05\end{array}$ & $\begin{array}{c}64.5 \\
16.3 \\
.84 \\
3.6 \\
2.4 \\
4.0 \\
3.1 \\
2.7 \\
.21 \\
1.2 \\
.80 \\
.19 \\
.05 \\
<.05\end{array}$ \\
\hline Total & 100.89 & 100.61 & 99.80 & 101.50 & 99.86 & 100.00 & 99.89 \\
\hline
\end{tabular}

Semiguantitative epectrographic analyses (weight percent)

\begin{tabular}{|c|c|c|c|c|c|c|}
\hline 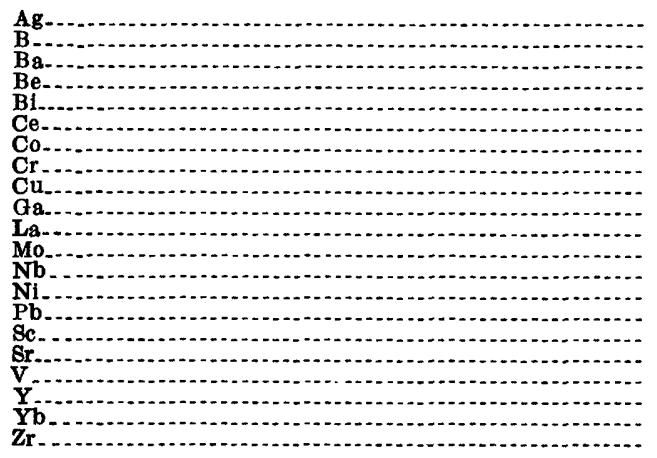 & $\begin{array}{l}0 \\
.001 \\
.05 \\
.00015 \\
0 \\
0 \\
.003 \\
.005 \\
.003 \\
.002 \\
.003 \\
0.001 \\
.0015 \\
.0015 \\
.002 \\
.07 \\
.015 \\
.003 \\
.0003 \\
.02\end{array}$ & $\begin{array}{l}0 \\
.001 \\
.05 \\
.00015 \\
0 \\
0 \\
.002 \\
.005 \\
.005 \\
.002 \\
0 \\
0 \\
.001 \\
.0015 \\
.002 \\
.002 \\
.05 \\
.015 \\
.003 \\
.0003 \\
.015\end{array}$ & $\begin{array}{l}0 \\
.0007 \\
.05 \\
.00015 \\
0 \\
0 \\
.002 \\
.005 \\
.0015 \\
.002 \\
0.0007 \\
.001 \\
.001 \\
.002 \\
.002 \\
.03 \\
.015 \\
.003 \\
.0003 \\
.01\end{array}$ & ( & $\begin{array}{l}0 \\
.0007 \\
.05 \\
.00015 \\
0 \\
0.001 \\
.0007 \\
.0015 \\
.002 \\
.003 \\
0.001 \\
.0003 \\
.0015 \\
.0007 \\
.07 \\
.007 \\
.0015 \\
.00015 \\
.015\end{array}$ & $\begin{array}{l}0 \\
.001 \\
.07 \\
.00015 \\
0 \\
0 \\
.0015 \\
.003 \\
.0005 \\
.002 \\
.005 \\
0.001 \\
.0007 \\
.002 \\
.001 \\
.05 \\
.01 \\
.002 \\
.00015 \\
.015\end{array}$ \\
\hline
\end{tabular}

Norms (weight percent)

\begin{tabular}{|c|c|c|c|c|c|c|c|}
\hline $\begin{array}{l}\text { ob } \\
\text { ab } \\
\text { wo } \\
\text { en } \\
\text { fs }\end{array}$ & $\begin{array}{r}14.2 \\
9.5 \\
29.7 \\
27.3 \\
0 \\
8.8 \\
5.9 \\
2.2 \\
1.7 \\
.6 \\
.2\end{array}$ & $\begin{array}{r}16.9 \\
10.7 \\
26.4 \\
25.4 \\
0 \\
9.0 \\
6.2 \\
2.2 \\
1.7 \\
.6 \\
.7\end{array}$ & $\begin{array}{r}20.6 \\
16.3 \\
26.0 \\
20.2 \\
0 \\
7.4 \\
5.5 \\
1.2 \\
1.8 \\
.4 \\
.7\end{array}$ & $\begin{array}{l}11.0 \\
17.0 \\
29.1 \\
19.9 \\
0.9 \\
7.4 \\
8.9 \\
2.0 \\
.3 \\
3.4 \\
1.2\end{array}$ & $\begin{array}{r}28.9 \\
6.5 \\
24.0 \\
22.9 \\
0 \\
4.7 \\
4.6 \\
5.2 \\
0.9 \\
2.2\end{array}$ & $\begin{array}{r}21.6 \\
10.8 \\
31.7 \\
21.0 \\
0 \\
5.0 \\
5.2 \\
1.4 \\
.8 \\
.6 \\
1.9\end{array}$ & $\begin{array}{c}22.7 \\
16.2 \\
26.6 \\
18.9 \\
0 \\
6.0 \\
4.8 \\
1.2 \\
1.5 \\
.4 \\
1.5\end{array}$ \\
\hline Total & 100.1 & 99.8 & 100.1 & 100.2 & 99.9 & 100.0 & 99.8 \\
\hline \multicolumn{8}{|c|}{ Niggli numbers } \\
\hline $\begin{array}{l}\text { si } \\
\text { fm } \\
\text { cm } \\
\text { quk } \\
\text { qz } \\
\mathbf{k} \\
\mathbf{m g}\end{array}$ & $\begin{array}{r}192.4 \\
33.3 \\
32.7 \\
19.9 \\
14.1 \\
36.0 \\
.2 \\
.5\end{array}$ & $\begin{array}{r}198.5 \\
32.8 \\
34.4 \\
19.3 \\
13.6 \\
44.2 \\
.3 \\
.5\end{array}$ & $\begin{array}{r}235.9 \\
34.8 \\
31.2 \\
16.8 \\
17.3 \\
66.8 \\
.4 \\
.5\end{array}$ & $\begin{array}{r}185.6 \\
31.9 \\
32.1 \\
19.8 \\
16.2 \\
20.7 \\
.4 \\
.4\end{array}$ & $\begin{array}{r}233.0 \\
35.1 \\
32.5 \\
19.9 \\
12.5 \\
83.0 \\
.2 \\
.3\end{array}$ & $\begin{array}{r}241.1 \\
38.8 \\
25.2 \\
18.2 \\
17.8 \\
69.7 \\
.2 \\
.5\end{array}$ & $\begin{array}{r}249.2 \\
37.1 \\
28.1 \\
16.6 \\
18.3 \\
76.2 \\
.4 \\
.5\end{array}$ \\
\hline
\end{tabular}

Modes (volume percent)

\begin{tabular}{|c|c|c|c|c|c|}
\hline $\begin{array}{l}\text { Plagioclase } \\
\text { K-feldspar } \\
\text { Quartz } \\
\text { Biotite } \\
\text { Hornblende. } \\
\text { Other }\end{array}$ & $\begin{array}{l}54 \\
<1 \\
15 \\
16 \\
15\end{array}$ & $\begin{array}{l}53 \\
<1 \\
19 \\
14 \\
14\end{array}$ & $\begin{array}{r}48 \\
9 \\
19 \\
8\end{array}$ & $\begin{array}{r}55 \\
1 \\
26 \\
15 \\
3\end{array}$ & $\begin{array}{r}47 \\
9 \\
25 \\
13 \\
6\end{array}$ \\
\hline Total & 100 & 100 & $100 \ldots$ & 100 & 100 \\
\hline
\end{tabular}


rocks of central Coast Ranges

by Chris Heropoulos (except BID-10, 19 and Leo-1, 2,3, and 4). Results are to be identified with geometric brackets whose boundaries are $1.2,0.83,0.56,0.38,0.26,0.18$, bracket at 68 percent, or two brackets at 95 percent confidence. Looked for but not found: $\mathrm{As}, \mathrm{Au}, \mathrm{Cd}, \mathrm{Ge}, \mathrm{Hf}, \mathrm{Hg}, \mathrm{In}, \mathrm{Li}, \mathrm{Pd}, \mathrm{Pt}, \mathrm{Re}, \mathrm{Sb}, \mathrm{Sn}, \mathrm{Ta}, \mathrm{Te}$, Th, Tl, U, W, Zn . garnet, $M=$ muscovite. Specife gravity: powder, determined by air pycnometer from part of split for chemical analysis; bulk, determined from specimen submitted for Ben Lomond unknown. n.d.=not determined

\begin{tabular}{|c|c|c|c|c|c|c|c|c|c|c|c|}
\hline \multicolumn{2}{|c|}{ Point Reyes-Continued } & \multicolumn{3}{|c|}{ Montara Mountain } & \multicolumn{7}{|c|}{ Ben Lomond } \\
\hline D R-532A & DR-518 & DR-1 & M-3 & HMB-1 & $\mathrm{L}-126$ & D R-499 & DR-496A & Leo-1 & Leo-2 & Leo-3 & Leo-4 \\
\hline \multicolumn{12}{|c|}{ Chemical anals ses (weight percent)-Continued } \\
\hline 70.2 & 73.2 & 58. 6 & 61.8 & 66. 3 & 63.4 & 68. 6 & 74. 3 & 50. 18 & 63. 59 & 71.01 & 73. 77 \\
\hline 15. 4 & 13. 6 & 17.2 & 17.0 & 16. 9 & 17.5 & 15.4 & 13. 5 & 15. 19 & 16. 96 & 15. 16 & 14.41 \\
\hline $\begin{array}{l}1.64 \\
\text {. } 6\end{array}$ & 1.20 & $\begin{array}{l}1.9 \\
5.3\end{array}$ & 5.82 & $\begin{array}{l}1.0 \\
2.8\end{array}$ & $\begin{array}{l}1.0 \\
4.0\end{array}$ & 3.46 & .88 & 7.85 & $\begin{array}{r}.97 \\
4.04\end{array}$ & 2.24 & .04 \\
\hline .97 & .40 & 3.6 & $\begin{array}{l}0.9 \\
1.9\end{array}$ & 1.5 & 2.4 & $\begin{array}{l}3.7 \\
1.4\end{array}$ & .31 & 7. 93 & 2.32 & .56 & .10 \\
\hline .64 & 1.1 & .96 & 1.8 & .94 & 1.0 & 1.0 & .76 & 1.42 & .49 & .60 & .30 \\
\hline $\begin{array}{r}.59 \\
.14\end{array}$ & .80 & .97 & $\begin{array}{l}.76 \\
46\end{array}$ & .64 & .11 & .24 & .54 & 1.94 & .66 & .29 & .03 \\
\hline .11 & .07 & .03 & .14 & $\begin{array}{l}.78 \\
.02\end{array}$ & .06 & .06 & .00 & .03 & .08 & .07 & .02 \\
\hline$<.05$ & $<.05$ & $<.05$ & $<.05$ & $<.05$ & $<.05$ & $<.05$ & $<.05$ & n.d. & n.d. & n.d. & n.d. \\
\hline 99.98 & 99.99 & 99.70 & 99.77 & 99.84 & 99.91 & 100.87 & 100.01 & 99.87 & 100.06 & 99.89 & 99.80 \\
\hline
\end{tabular}

\begin{tabular}{|c|c|c|c|c|c|c|c|c|}
\hline \multicolumn{9}{|c|}{ Semiquautitative spectrographic analyses (weight percent)-Continued } \\
\hline $\begin{array}{l}0 \\
0 \\
.1 \\
.00015 \\
0 \\
0 \\
.0007 \\
.0005 \\
.0003 \\
.002 \\
0 \\
0 \\
.001 \\
.0001 \\
.003 \\
.0005 \\
.07 \\
.005 \\
.0015 \\
.0001 \\
.015\end{array}$ & $\begin{array}{l}0 \\
.001 \\
.07 \\
.0003 \\
0 \\
.01 \\
.0002 \\
.0005 \\
.0005 \\
.002 \\
.005 \\
0.001 \\
.001 \\
.003 \\
.0007 \\
.01 \\
.0015 \\
.003 \\
.0003 \\
.02\end{array}$ & $\begin{array}{c}<0.00007 \\
0 \\
.03 \\
.0001 \\
.002 \\
0 \\
.0015 \\
.005 \\
.0015 \\
.0015 \\
.003 \\
.0003 \\
.0007 \\
.0015 \\
.001 \\
.002 \\
.07 \\
.01 \\
.003 \\
.0003 \\
.01\end{array}$ & $\begin{array}{l}<0.00007 \\
0 \\
.07 \\
0 \\
.0007 \\
0.001 \\
.0007 \\
.001 \\
.0015 \\
.003 \\
.0003 \\
.0007 \\
.00015 \\
.001 \\
.002 \\
.05 \\
.007 \\
.005 \\
.0005 \\
.02\end{array}$ & $\begin{array}{l}0 \\
0 \\
.07 \\
.0001 \\
0 \\
0 \\
.0007 \\
.0007 \\
.0007 \\
.0015 \\
.003 \\
0.0007 \\
.0007 \\
.003 \\
.001 \\
.007 \\
.07 \\
.005 \\
.0015 \\
.0001 \\
.015\end{array}$ & $\begin{array}{l}0 \\
.0015 \\
.07 \\
.0001 \\
0 \\
0 \\
.0015 \\
.0015 \\
.0007 \\
.002 \\
0 \\
0 \\
.001 \\
.0007 \\
.001 \\
.002 \\
.05 \\
.01 \\
.002 \\
.0002 \\
.03\end{array}$ & $\begin{array}{l}0 \\
.001 \\
.07 \\
.0002 \\
0 \\
0 \\
.001 \\
.0015 \\
.0015 \\
.002 \\
.003 \\
0.001 \\
.001 \\
.0001 \\
.003 \\
.0015 \\
.03 \\
.007 \\
.003 \\
.0003 \\
.03\end{array}$ & $\begin{array}{l}0 \\
.0015 \\
.03 \\
.0003 \\
0 \\
0 \\
0 \\
.00015 \\
.0005 \\
.0015 \\
.003 \\
0.0007 \\
.0007 \\
.005 \\
.0003 \\
.005 \\
.001 \\
.003 \\
.0003 \\
.007\end{array}$ & 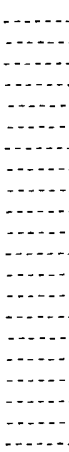 \\
\hline
\end{tabular}

\begin{tabular}{|c|c|c|c|c|c|c|c|c|c|c|c|}
\hline \multicolumn{12}{|c|}{ Norms (weight percent) - Continued } \\
\hline $\begin{array}{c}30.8 \\
19.1 \\
28.1 \\
14.1 \\
0 \\
2.4 \\
1.6 \\
1.1 \\
1.1 \\
.3 \\
1.4\end{array}$ & $\begin{array}{r}33.4 \\
23.9 \\
31.7 \\
6.0 \\
0 \\
1.0 \\
.5 \\
.9 \\
1.5 \\
0 \\
1.0\end{array}$ & $\begin{array}{r}16.9 \\
7.8 \\
24.0 \\
28.9 \\
0 \\
9.1 \\
6.7 \\
2.8 \\
1.9 \\
1.2 \\
.8\end{array}$ & $\begin{array}{r}21.3 \\
6.6 \\
32.9 \\
18.2 \\
0 \\
4.8 \\
9.2 \\
1.2 \\
1.5 \\
1.1 \\
3.1\end{array}$ & $\begin{array}{c}30.9 \\
10.2 \\
29.1 \\
13.4 \\
0 \\
3.8 \\
3.3 \\
1.5 \\
1.2 \\
1.9 \\
4.7\end{array}$ & $\begin{array}{r}19.7 \\
10.8 \\
29.1 \\
20.3 \\
0 \\
6.0 \\
6.5 \\
1.5 \\
.2 \\
.1 \\
.8\end{array}$ & $\begin{array}{c}27.4 \\
19.1 \\
26.6 \\
15.4 \\
0 \\
3.5 \\
5.8 \\
.4 \\
.5 \\
.1 \\
1.3\end{array}$ & $\begin{array}{r}32.9 \\
28.6 \\
29.9 \\
5.0 \\
0 \\
.8 \\
.7 \\
.3 \\
1.0 \\
0.7 \\
.7\end{array}$ & $\begin{array}{r}2.7 \\
2.3 \\
12.8 \\
34.2 \\
12.0 \\
20.1 \\
11.0 \\
1.1 \\
3.7 \\
0^{.1}\end{array}$ & $\begin{array}{r}20.2 \\
10.0 \\
28.4 \\
26.5 \\
.5 \\
5.8 \\
5.7 \\
1.4 \\
1.3 \\
.3 \\
0\end{array}$ & $\begin{array}{c}29.3 \\
22.2 \\
36.4 \\
7.9 \\
0 \\
1.4 \\
0 \\
.2 \\
.6 \\
.3 \\
1.5\end{array}$ & $\begin{array}{r}27.7 \\
48.0 \\
21.0 \\
.6 \\
0 \\
.3 \\
.2 \\
.1 \\
.1 \\
.2 \\
1.3\end{array}$ \\
\hline 100.0 & 99.9 & 100.1 & 99.9 & 100.0 & 100.0 & 100.1 & 99.9 & 100.0 & 100.1 & 99.8 & 100.1 \\
\hline \multicolumn{12}{|c|}{ Niggli numbers-Continued } \\
\hline $\begin{array}{r}334.9 \\
43.3 \\
16.4 \\
15.3 \\
25.0 \\
134.9 \\
.4 \\
.4\end{array}$ & $\begin{array}{r}417.5 \\
45.7 \\
12.0 \\
7.3 \\
35.0 \\
177.5 \\
.4 \\
.3\end{array}$ & $\begin{array}{r}184.3 \\
31.9 \\
35.4 \\
21.6 \\
11.2 \\
39.8 \\
.2 \\
.5\end{array}$ & $\begin{array}{r}226.2 \\
36.7 \\
30.8 \\
16.5 \\
16.1 \\
62.0 \\
.2 \\
.3\end{array}$ & $\begin{array}{r}280.3 \\
42.1 \\
22.6 \\
16.8 \\
18.5 \\
106.3 \\
.3 \\
.4\end{array}$ & $\begin{array}{r}226.9 \\
36.9 \\
27.6 \\
19.6 \\
15.9 \\
63.3 \\
.3 \\
.5\end{array}$ & $\begin{array}{r}303.3 \\
40.1 \\
22.9 \\
14.7 \\
22.3 \\
114.1 \\
.4 \\
.4\end{array}$ & $\begin{array}{r}438.7 \\
47.0 \\
8.6 \\
6.3 \\
38.1 \\
186.3 \\
.5 \\
.3\end{array}$ & $\begin{array}{r}116.4 \\
20.8 \\
44.2 \\
31.1 \\
3.9 \\
.7 \\
.2 \\
.6\end{array}$ & $\begin{array}{r}226.4 \\
35.6 \\
27.2 \\
21.9 \\
15.3 \\
65.0 \\
.3 \\
.5\end{array}$ & $\begin{array}{r}385.7 \\
48.5 \\
6.9 \\
9.9 \\
34.7 \\
147.0 \\
.4 \\
.7\end{array}$ & $\begin{array}{r}443.0 \\
51.0 \\
1.9 \\
1.4 \\
45.7 \\
160.0 \\
.7 \\
.5\end{array}$ \\
\hline \multicolumn{12}{|c|}{ Modes (volume percent)-Continued } \\
\hline $\begin{array}{r}45 \\
18 \\
28 \\
8 \\
1\end{array}$ & $\begin{array}{r}34 \\
26 \\
35 \\
5 \\
\end{array}$ & $\begin{array}{r}53 \\
1 \\
12 \\
16 \\
18\end{array}$ & $\begin{array}{r}57 \\
<1 \\
22 \\
15 \\
6\end{array}$ & $\begin{array}{r}57 \\
1 \\
26 \\
12 \\
4\end{array}$ & $\begin{array}{r}50 \\
1 \\
28 \\
14 \\
7\end{array}$ & $\begin{array}{r}47 \\
6 \\
30 \\
13 \\
4 \\
(\mathrm{Clp})<1\end{array}$ & $\begin{array}{r}38 \\
30 \\
31 \\
1 \\
\\
\end{array}$ & $\begin{array}{r}42.8 \\
\text { (S) } 1.0 \\
\text { (I) } 2.5 \\
\text { (R) } .4\end{array}$ & $\begin{array}{r}52.0 \\
.4 \\
30.5 \\
12.4 \\
3.7 \\
1.0\end{array}$ & $\begin{array}{r}39.8 \\
26.9 \\
27.6 \\
5.3 \\
\text { (G) } .4\end{array}$ & $\begin{array}{r}13.8 \\
60.7 \\
25.1 \\
\text { (Mu) } .3 \\
\text { (G) } .1\end{array}$ \\
\hline 100 & 100 & 100 & 100 & 100 & 100 & 100 & 100 & 100.0 & 100.0 & 100.0 & 100.0 \\
\hline
\end{tabular}


TABLE 29.-Chemical data on basement

\begin{tabular}{|c|c|c|c|c|c|c|c|}
\hline & \multicolumn{5}{|c|}{ Bodega Head } & \multicolumn{2}{|c|}{ Point Reyes } \\
\hline & DR-511A & DR-510 & DR-505 & BID-19 & BID-10 & DR-526 & DR-625 \\
\hline \multicolumn{8}{|c|}{ Specific gravity } \\
\hline $\begin{array}{l}\text { Powder } \\
\text { Bulk } \\
\text { Hand specimen }\end{array}$ & $\begin{array}{l}2.85 \\
2.75 \\
2.77\end{array}$ & $\begin{array}{l}2.85 \\
2.78 \\
2.77\end{array}$ & $\begin{array}{l}2 . \\
2 .\end{array}$ & & & $\begin{array}{l}2.83 \\
2.68 \\
2.72\end{array}$ & $\begin{array}{l}2.78 \\
2.71 \\
2.72\end{array}$ \\
\hline
\end{tabular}

Bodega Head: LOCALITIBS FOR TABLE 29 (SEE PL. 1)

DR-511A. Hornblende-biotite quartz diorite. Mussel Point, Bodega Head DR-510. Hornblende-biotite quartz diorite. Material from "Reactor Hole," D R-505. Bodega Head 71/2-min quad.

D R-505. Biotite-hornblende granodiorite. Beach cliff 5,000 ft S. of Horseshoe BID-19. Biotite diorite from south end of Bodega Peninsula (Osmont, 1905); probably an inclusion in BID-10 type.
BID-10. Quartz diorite from south end of Bodega Peninsula (Osmont, 1905). DR-526. Biotite quartz diorite. Tomales Point, Tomales 71/2-min quad.

DR-525. Hornblende-biotite granodiorite. McClures Beach, Tomales $71 / 2-m i n$ quad.
DR-532A. Biotite granodiorite. Point Reyes Life Boat Station. Drakes Bay DR-518. Biotite quartz monzonite. Sir Francis Drake Highway, 2 miles W. D R-518. Biotite quartz monzonite. Sir Francis Drake
of Inverness, Drakes Bay $71 / 3-$-min quad.

TABLE 30.-Chemical data on basement

[Chemical analyses by P. L. D. Elmore, Lowell Artis, S. D. Botts, Gillison Chloe, J. L. G l enn, James Kelsey, and Hezekiah Smith. Semiquantitative spectrographic analyses $1.2,0.83,0.56,0.38,0.26,0.18,0.12$, etc., but are reported arbitrarily as midpoints of these brackets, $1,0.7,0.5,0.3,0.2,0.15,0.1$, etc. The precision of a reported value is $\mathrm{Sn}, \mathrm{Ts}, \mathrm{Te}, \mathrm{Th}, \mathrm{Tl}, \mathrm{U}, \mathrm{W}, \mathrm{Zn}$. Also looked for but not found where La or Ce found: Pr, Sm, Eu. Norms: symbols for other minerals are cc=calcite, fo=forsterite,
$\mathbf{M u}=$ muscovite, $\mathbf{A l}=$ allanite, $\mathrm{Ch}=$ chlorite. Specific gravity: powder, determined by air pycnometer from part of split for chemical analysis; bulk, determined from

\begin{tabular}{|c|c|c|c|c|c|c|c|c|c|}
\hline \multicolumn{8}{|c|}{ Gabilan Range } & \multicolumn{2}{|c|}{ Stockdale Mountain } \\
\hline & DR-570 & $D R-584$ & DR-566A & $G-1 B$ & $\mathrm{G}-1 \mathrm{~A}$ & D R-576 & DR-546 & DR-145C & D R-142 \\
\hline \multicolumn{10}{|c|}{ Chemical analyses (weight percent) } \\
\hline 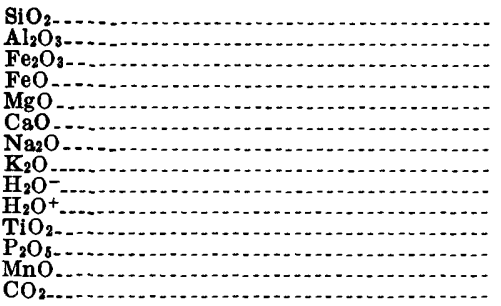 & $\begin{array}{r}61.6 \\
16.9 \\
1.6 \\
3.7 \\
2.6 \\
5.8 \\
3.6 \\
1.9 \\
.07 \\
1.0 \\
.90 \\
.24 \\
.12 \\
<.05\end{array}$ & $\begin{array}{r}62.1 \\
16.8 \\
1.5 \\
3.7 \\
2.6 \\
5.2 \\
3.3 \\
2.2 \\
.12 \\
1.2 \\
.87 \\
.20 \\
.10 \\
<.05\end{array}$ & $\begin{array}{l}65.5 \\
15.8 \\
1.1 \\
2.8 \\
2.0 \\
4.1 \\
3.6 \\
3.1 \\
.09 \\
1.0 \\
.65 \\
.17 \\
.10 \\
<.05\end{array}$ & $\begin{array}{r}66.4 \\
16.2 \\
1.6 \\
2.2 \\
1.4 \\
3.7 \\
3.5 \\
3.0 \\
.02 \\
.88 \\
.78 \\
.18 \\
.05 \\
<.05\end{array}$ & $\begin{array}{l}71.5 \\
14.7 \\
.79 \\
1.1 \\
.68 \\
2.3 \\
3.2 \\
4.4 \\
.05 \\
.51 \\
.31 \\
.07 \\
.25 \\
<.05\end{array}$ & $\begin{array}{c}74.6 \\
14.0 \\
.00 \\
.61 \\
.66 \\
1.7 \\
3.4 \\
4.3 \\
.05 \\
.77 \\
.12 \\
.05 \\
.07 \\
<.05\end{array}$ & $\begin{array}{c}75.0 \\
13.4 \\
.21 \\
.68 \\
.15 \\
1.0 \\
2.9 \\
5.7 \\
.05 \\
.60 \\
.11 \\
.03 \\
.03 \\
<.05\end{array}$ & $\begin{array}{r}66.8 \\
15.9 \\
1.5 \\
2.3 \\
1.4 \\
3.6 \\
3.7 \\
3.0 \\
.02 \\
.71 \\
.76 \\
.20 \\
.16 \\
<.05\end{array}$ & $\begin{array}{r}67.8 \\
16.1 \\
1.6 \\
1.5 \\
1.1 \\
3.3 \\
3.7 \\
3.0 \\
.09 \\
.68 \\
.75 \\
.18 \\
.12 \\
<.05\end{array}$ \\
\hline \multirow[t]{3}{*}{ Total } & 100.03 & 99.89 & 100.01 & 99.91 & 99.86 & 99.93 & 99.86 & 100.05 & 99.92 \\
\hline & & \multicolumn{2}{|c|}{ Logan } & & \multicolumn{3}{|c|}{ Gold Hill } & \multicolumn{2}{|r|}{ Monterey } \\
\hline & & HBGB-8 & DR-589B & DR-588A & $\mathbf{D R}$ & & -132 & D R-121 & Mo-1B \\
\hline
\end{tabular}

Chemical analyses (weight percent)

\begin{tabular}{|c|c|c|c|c|c|c|c|}
\hline $\begin{array}{l}\mathrm{SiO}^{\mathrm{AO}} \mathrm{O}_{2} \mathrm{O}_{2} \\
\mathrm{~F}_{2} \mathrm{O}_{3} \\
\mathrm{~F} \mathrm{O}_{3} \mathrm{O}\end{array}$ & $\begin{array}{r}49.36 \\
16.88 \\
6.49 \\
6.94 \\
4.80 \\
7.58 \\
3.41 \\
.72 \\
.41 \\
2.90 \\
\text { Trace } \\
.34 \\
.61 \\
\text { n.d. }\end{array}$ & $\begin{array}{r}52.6 \\
17.7 \\
2.2 \\
7.3 \\
5.5 \\
10.2 \\
1.8 \\
.24 \\
.06 \\
1.2 \\
.58 \\
.10 \\
.17 \\
.29\end{array}$ & $\begin{array}{r}53.6 \\
18.7 \\
2.7 \\
6.0 \\
4.3 \\
10.0 \\
2.1 \\
.18 \\
.11 \\
1.2 \\
.63 \\
.08 \\
.15 \\
.10\end{array}$ & $\begin{array}{r}48.2 \\
19.6 \\
1.1 \\
3.2 \\
8.5 \\
14.8 \\
1.7 \\
.30 \\
.08 \\
1.7 \\
.22 \\
.01 \\
.18 \\
<.05\end{array}$ & $\begin{array}{c}54.3 \\
14.9 \\
3.3 \\
7.0 \\
6.7 \\
8.7 \\
1.5 \\
.20 \\
.08 \\
2.4 \\
.06 \\
.03 \\
.20 \\
<.05\end{array}$ & $\begin{array}{r}55.5 \\
17.8 \\
1.9 \\
6.3 \\
5.3 \\
10.1 \\
1.2 \\
.20 \\
.04 \\
.77 \\
.39 \\
.06 \\
.14 \\
<.05\end{array}$ & $\begin{array}{c}73.5 \\
14.4 \\
.53 \\
.88 \\
.33 \\
2.1 \\
3.7 \\
3.3 \\
.09 \\
.68 \\
.20 \\
.05 \\
.08 \\
<.05\end{array}$ \\
\hline Total & 100.34 & 99.94 & 99.85 & 99.59 & 99.87 & 99.7 & 99.8 \\
\hline
\end{tabular}


rocks of central Coast Ranges-Continued

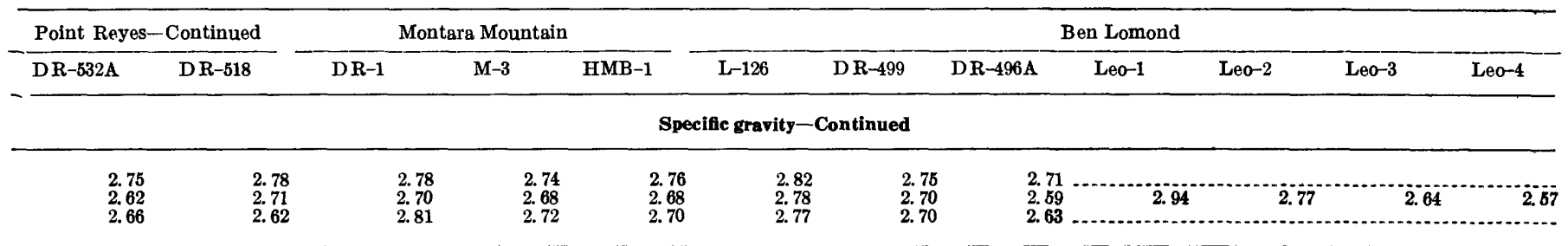

Montara Mountain:

DR-1. Biotito-hornblende quartz diorite. Arroyo de en Medio, Montara Mountain $71 / 2$-min quad

M-3. Hornblende-biotite quartz diorite, 7,000 ft S. of Devils Slide, Highway 1. Montara Mountain 71/2-min quad.

HMB-1. Hornblende-biotite quartz diorite. SW1/4 sec. 14, T. 5 S., R. $5 \mathrm{~W}$ Ben Lomond: Half Moon Bay $71 / 2$-min quad.

L-126. Hornblende-biotite quartz diorite. Same locality as Leo-2. Davenport $71 / 2-$ min quad.
D R-499. Biotite granodiorite-"gnelss." SE 1/4 sec. 12, T. 10 S., R. 2 W. Davenport 71/2-min quad.

DR-496A. Alaskite. Empire Grade 0.7 mile N. of Smith Grade intersection. Felton $71 / 2$-min quad.

Leo-1. Hornblende gabbro near Pine Flat Road (Leo, 1967)

Leo-2. Quartz diorite, Alba Road, $800 \mathrm{ft} \mathrm{SW.} \mathrm{of} \mathrm{Empire} \mathrm{Grade} \mathrm{(Leo,} \mathrm{1967)}$ Leo-3. Quartz monzonite, Laguna Creek, $500 \mathrm{yd} \mathrm{N}$. of sandstone-granitic Aplite, Laguna Creek, 0.5 mile S. of Ice Cream Grade (Leo, 1967).

\section{rocks of southern Coast Ranges}

by Chris Heropoulos (except HB GB-8 of Logan and, as indicated, Santa Lucia Range specimens). Results are to be identified with geometric brackets whose boundaries are approximately plus or minus one bracket at 68 percent, or two brackets at 95 percent confidence. Looked for but not found: As, Au, Cd, Ge, Hf, Hg, In, Li, Pd, Pt, Re, Sb, $\mathrm{fa}=$ fayalite, $\mathrm{hm}=$ hematite, $\mathrm{ru}=$ rutile $\mathrm{cm}=$ chromite, $\mathrm{pr}=$ pyrite, $\mathrm{fr}=$ fiuorite. Modes: symbols for other minerals are $\mathrm{E}=\mathrm{epidote}, \mathrm{S}=$ sphene, Me $=$ metallic opaque minerals, specimen submitted for chemical analysis; hand specimen, is bulk determination by water submersion method on larger sample. n.d.=not determined]

\begin{tabular}{|c|c|c|c|c|c|c|c|c|c|c|c|c|c|c|}
\hline \multicolumn{5}{|c|}{ La Panza Range } & \multicolumn{2}{|c|}{ San Juan Creek } & \multicolumn{3}{|c|}{ Red Hills } & \multicolumn{5}{|c|}{ Barrett Ridge } \\
\hline B R-6-3 & P-1 & LaP-3 & P-7A & SLO-10B & DR-63A & DR-66 & $\mathrm{C}-1 \mathrm{~A}$ & D R-109 & DR-100 & D R-59 & DR-46 & D R-24A & DR-20A & $\mathrm{BM}-1 \mathrm{C}$ \\
\hline \multicolumn{15}{|c|}{ Chemical analyses (weight percent)-Continued } \\
\hline $\begin{array}{c}62.2 \\
16.8 \\
1.8 \\
3.4 \\
2.3 \\
4.8 \\
3.7 \\
2.2 \\
.08 \\
1.1 \\
.78 \\
.42 \\
.11 \\
.24\end{array}$ & $\begin{array}{c}67.5 \\
15.9 \\
1.5 \\
2.2 \\
1.4 \\
3.4 \\
3.2 \\
2.6 \\
.07 \\
.62 \\
.60 \\
.43 \\
.04 \\
<.05\end{array}$ & $\begin{array}{c}68.2 \\
16.1 \\
1.2 \\
2.0 \\
1.2 \\
2.9 \\
3.1 \\
3.5 \\
.00 \\
.71 \\
.55 \\
.58 \\
.02 \\
<.05\end{array}$ & $\begin{array}{c}70.0 \\
15.2 \\
.70 \\
2.0 \\
1.0 \\
2.1 \\
2.9 \\
3.0 \\
.09 \\
.61 \\
.44 \\
.95 \\
.03 \\
.05\end{array}$ & $\begin{array}{c}70.6 \\
15.7 \\
.74 \\
.96 \\
.86 \\
1.9 \\
2.8 \\
4.6 \\
.10 \\
.66 \\
.29 \\
.66 \\
.04 \\
<.05\end{array}$ & $\begin{array}{c}73.7 \\
14.3 \\
.70 \\
.64 \\
.27 \\
1.2 \\
2.6 \\
4.9 \\
.07 \\
.51 \\
.20 \\
.06 \\
.02 \\
.05\end{array}$ & $\begin{array}{c}75.4 \\
13.8 \\
.00 \\
.47 \\
.20 \\
.84 \\
4.1 \\
4.5 \\
.00 \\
.33 \\
.18 \\
.04 \\
.17 \\
<.05\end{array}$ & $\begin{array}{c}56.9 \\
18.0 \\
2.2 \\
4.6 \\
3.7 \\
4.6 \\
3.3 \\
2.3 \\
.29 \\
1.7 \\
1.2 \\
.68 \\
.07 \\
.42\end{array}$ & $\begin{array}{r}62.7 \\
16.8 \\
1.9 \\
3.3 \\
2.7 \\
4.1 \\
3.1 \\
2.3 \\
.15 \\
1.0 \\
.76 \\
.51 \\
.08 \\
<.05\end{array}$ & $\begin{array}{c}69.0 \\
15.4 \\
.71 \\
1.9 \\
1.3 \\
3.0 \\
2.7 \\
3.5 \\
.08 \\
.69 \\
.39 \\
.38 \\
.08 \\
.08\end{array}$ & $\begin{array}{r}66.2 \\
15.2 \\
2.0 \\
3.3 \\
1.9 \\
1.2 \\
2.4 \\
5.4 \\
.05 \\
1.0 \\
.65 \\
.04 \\
.18 \\
<.05\end{array}$ & $\begin{array}{c}70.1 \\
13.0 \\
3.2 \\
2.3 \\
.55 \\
1.9 \\
2.5 \\
4.7 \\
.00 \\
.68 \\
.68 \\
.15 \\
.18 \\
<.05\end{array}$ & $\begin{array}{c}73.4 \\
12.6 \\
.00 \\
1.8 \\
.89 \\
2.4 \\
2.5 \\
4.0 \\
.00 \\
.64 \\
.78 \\
.18 \\
.09 \\
<.05\end{array}$ & $\begin{array}{c}73.6 \\
13.0 \\
1.8 \\
1.6 \\
.67 \\
1.8 \\
2.4 \\
3.8 \\
.02 \\
.52 \\
.52 \\
.12 \\
.02 \\
.05\end{array}$ & $\begin{array}{c}71.7 \\
14.7 \\
.59 \\
.74 \\
.60 \\
2.3 \\
3.6 \\
4.2 \\
.00 \\
.51 \\
.22 \\
.04 \\
.06 \\
<.05\end{array}$ \\
\hline 99.93 & 99.46 & 100.06 & 99.07 & 99.91 & 99.22 & 100.03 & 99.96 & 99.40 & 99.21 & 99.52 & 99.89 & 99.28 & 99.92 & $\overrightarrow{99.26}$ \\
\hline
\end{tabular}

Santa Lucia Range (Unpub. analyses furnished by R. C. Pearson. Specimens located and described in Pearson and others (1967))

Santa Lucia Range (Compton, 1966, p. 280)

\begin{tabular}{|c|c|c|c|c|c|c|c|c|c|c|c|c|c|c|c|}
\hline$P-43$ & P-144 & $\mathrm{H}-135$ & P-85 & $\mathrm{P}-\mathbf{1 3 5}$ & P-94 & $\mathrm{H}-135$ & $\mathrm{P}-222$ & H-39 & H-75 & CP-8-68A & $\mathrm{BC}-3-32 \mathrm{~B}$ & CP-2-1 & $J S P-6-2$ & JS-1 & BC-1-4C \\
\hline \multicolumn{16}{|c|}{ Chemical analyses (weight percent)-Continued } \\
\hline $\begin{array}{r}46.6 \\
8.7 \\
2.4 \\
9.4 \\
19.8 \\
9.3 \\
1.1 \\
.56 \\
.00 \\
.86 \\
.56 \\
.23 \\
.26 \\
.08\end{array}$ & $\begin{array}{r}47.4 \\
14.5 \\
2.8 \\
9.5 \\
9.6 \\
10.6 \\
1.4 \\
.90 \\
.16 \\
.12 \\
1.7 \\
.38 \\
.24 \\
<.05\end{array}$ & $\begin{array}{c}52.5 \\
14.5 \\
1.7 \\
6.7 \\
9.1 \\
9.1 \\
1.8 \\
1.0 \\
.06 \\
1.5 \\
1.2 \\
.42 \\
.20 \\
<.05\end{array}$ & $\begin{array}{r}63.4 \\
15.9 \\
1.5 \\
3.4 \\
2.5 \\
5.5 \\
3.4 \\
2.0 \\
.04 \\
.95 \\
.90 \\
.37 \\
.13 \\
<.05\end{array}$ & $\begin{array}{c}64.0 \\
16.5 \\
1.4 \\
2.7 \\
1.8 \\
5.1 \\
3.5 \\
2.8 \\
.02 \\
.83 \\
.66 \\
.36 \\
.12 \\
<.05\end{array}$ & $\begin{array}{r}64.2 \\
15.9 \\
1.5 \\
2.7 \\
2.0 \\
5.1 \\
3.3 \\
2.9 \\
.08 \\
.88 \\
.74 \\
.36 \\
.12 \\
.10\end{array}$ & $\begin{array}{c}72.0 \\
14.7 \\
.76 \\
1.4 \\
.31 \\
1.5 \\
3.8 \\
4.3 \\
.02 \\
.85 \\
.14 \\
.16 \\
.10 \\
<.05\end{array}$ & $\begin{array}{c}73.1 \\
14.0 \\
.23 \\
.24 \\
.20 \\
.90 \\
2.8 \\
6.5 \\
.03 \\
.67 \\
1.0 \\
.15 \\
.06 \\
<.05\end{array}$ & $\begin{array}{c}73.3 \\
14.3 \\
.36 \\
.76 \\
.50 \\
2.3 \\
3.1 \\
4.0 \\
.00 \\
.57 \\
.24 \\
.21 \\
.06 \\
<.05\end{array}$ & $\begin{array}{c}74.2 \\
13.6 \\
.40 \\
1.0 \\
.30 \\
1.2 \\
3.2 \\
4.7 \\
.00 \\
.74 \\
.12 \\
.22 \\
.17 \\
.06\end{array}$ & $\begin{array}{r}47.82 \\
5.10 \\
1.03 \\
8.45 \\
20.43 \\
14.57 \\
.53 \\
.11 \\
.26 \\
1.12 \\
.56 \\
\text { n.d. } \\
\text { n.d. } \\
\text { n.d. }\end{array}$ & $\begin{array}{r}53.04 \\
9.98 \\
1.20 \\
7.30 \\
13.58 \\
10.53 \\
1.08 \\
.36 \\
.46 \\
1.04 \\
.61 \\
\text { n.d. } \\
\text { n.d. } \\
\text { n.d. }\end{array}$ & $\begin{array}{r}55.85 \\
19.64 \\
1.70 \\
5.59 \\
2.38 \\
6.29 \\
4.64 \\
1.32 \\
.31 \\
1.01 \\
1.19 \\
\text { n.d. } \\
\text { n.d. } \\
\text { n.d. }\end{array}$ & $\begin{array}{c}71.74 \\
13.46 \\
1.52 \\
2.03 \\
0.94 \\
2.22 \\
3.35 \\
3.30 \\
.33 \\
.69 \\
.42 \\
\text { n.d. } \\
\text { n.d. } \\
\text { n.d. }\end{array}$ & $\begin{array}{r}71.90 \\
14.76 \\
.06 \\
1.55 \\
.63 \\
2.11 \\
3.10 \\
4.50 \\
.16 \\
.43 \\
.45 \\
\text { n.d. } \\
\text { n.d. } \\
\text { n.d. }\end{array}$ & $\begin{array}{r}73.66 \\
\text { 13. } 86 \\
.35 \\
.79 \\
.43 \\
.82 \\
1.92 \\
6.79 \\
.25 \\
.26 \\
.16 \\
\text { n.d. } \\
\text { n.d. } \\
\text { n.d. }\end{array}$ \\
\hline 99.85 & 99.30 & 99.78 & 100.00 & 99.79 & 99.88 & 100.04 & 99.88 & 99.70 & 99.85 & 99.98 & 99. 18 & 99.92 & 100.00 & 99.65 & 99.28 \\
\hline
\end{tabular}


TABLE 30.-Chemical data on basement

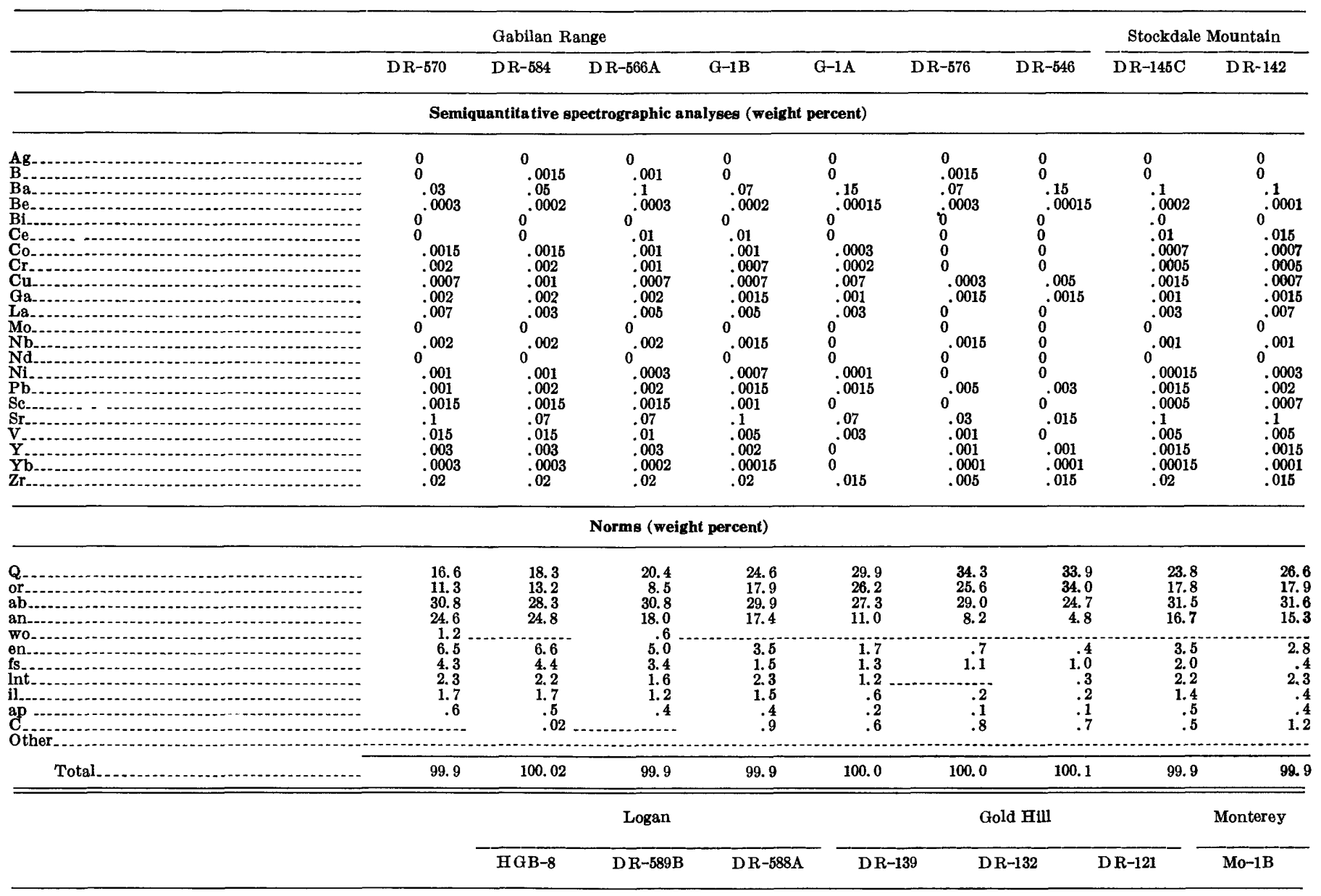

Semiquantitative spectrographic analyses (weight percent)

\begin{tabular}{|c|c|c|c|c|c|c|}
\hline $\begin{array}{l}{ }_{1}^{\mathrm{B}} \mathrm{B} \\
\mathrm{B}\end{array}$ & $\begin{array}{l}0 \\
0 \\
.007 \\
0 \\
0 \\
0 \\
.005 \\
.005 \\
.03 \\
.0015 \\
0 \\
0 \\
0 \\
.003 \\
0.005 \\
.015 \\
.05 \\
.002 \\
.0002 \\
.0015\end{array}$ & $\begin{array}{l}0 \\
0 \\
0 \\
0 \\
0 \\
005 \\
.005 \\
.0015 \\
.01 \\
.0015 \\
0 \\
0 \\
0 \\
.001 \\
0 \\
.005 \\
.02 \\
.03 \\
.002 \\
.0002 \\
.003\end{array}$ & $\begin{array}{l}0 \\
0 \\
.007 \\
0 \\
0 \\
0 \\
.003 \\
.00 \\
.005 \\
.001 \\
0 \\
0 \\
0 \\
0 \\
.007 \\
0.005 \\
.005 \\
.03 \\
.01 \\
0 \\
0 \\
.0005\end{array}$ & $\begin{array}{l}0 \\
0 \\
.01 \\
0 \\
0 \\
0 \\
.005 \\
.015 \\
.007 \\
.001 \\
0 \\
0 \\
0 \\
0 \\
.005 \\
0.007 \\
.015 \\
.015 \\
.001 \\
.0001 \\
.002\end{array}$ & $\begin{array}{l}0 \\
0 \\
.007 \\
0 \\
0 \\
0 \\
.003 \\
.005 \\
.007 \\
.001 \\
0 \\
0 \\
0 \\
0 \\
.003 \\
0.005 \\
.02 \\
.02 \\
.0015 \\
.00015 \\
.0015\end{array}$ & $\begin{array}{l}0 \\
0 \\
.1 \\
.0002 \\
0 \\
0 \\
0 \\
.00015 \\
.0007 \\
.001 \\
.005 \\
0.001 \\
.001 \\
0^{\circ} .0003 \\
.002 \\
0.05 \\
.05 \\
.003 \\
.0003 \\
.015\end{array}$ \\
\hline
\end{tabular}

\begin{tabular}{|c|c|c|c|c|c|c|c|}
\hline \multicolumn{8}{|c|}{ Norms (weight percent) } \\
\hline $\begin{array}{l}\text { Q } \\
\text { or } \\
\text { ab } \\
\text { an } \\
\text { wo } \\
\text { en } \\
\text { fs }\end{array}$ & $\begin{array}{r}1.9 \\
4.4 \\
29.7 \\
29.5 \\
2.9 \\
12.3 \\
8.8 \\
9.7\end{array}$ & $\begin{array}{r}9.2 \\
1.4 \\
15.4 \\
40.0 \\
3.6 \\
13.9 \\
11.1 \\
3.2 \\
1.1\end{array}$ & $\begin{array}{r}11.5 \\
1.1 \\
18.0 \\
41.7 \\
3.1 \\
10.9 \\
8.1 \\
4.0 \\
1.2\end{array}$ & $\begin{array}{r}1.8 \\
14.7 \\
46.0 \\
12.1 \\
12.0 \\
2.8 \\
1.6 \\
.4\end{array}$ & $\begin{array}{r}14.4 \\
1.2 \\
13.0 \\
34.2 \\
4.1 \\
17.1 \\
9.8 \\
4.9 \\
1.1\end{array}$ & $\begin{array}{r}15.6 \\
1.1 \\
10.2 \\
42.4 \\
3.2 \\
13.3 \\
10.5 \\
2.8 \\
.7\end{array}$ & $\begin{array}{l}34.4 \\
19.7 \\
31.6 \\
10.2 \\
.8 \\
1.0 \\
.8\end{array}$ \\
\hline ap & .8 & .2 & .2 & $\operatorname{tr}$ & .1 & .1 & 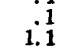 \\
\hline
\end{tabular}

\begin{tabular}{cccccccc}
\cline { 2 - 2 } & & & \\
Total & 100.0 & 99.8 & 100.0 & 99.8 & 99.9 & 99.9 & 100.1 \\
\hline
\end{tabular}


rocks of southern Coast Ranges-Continued

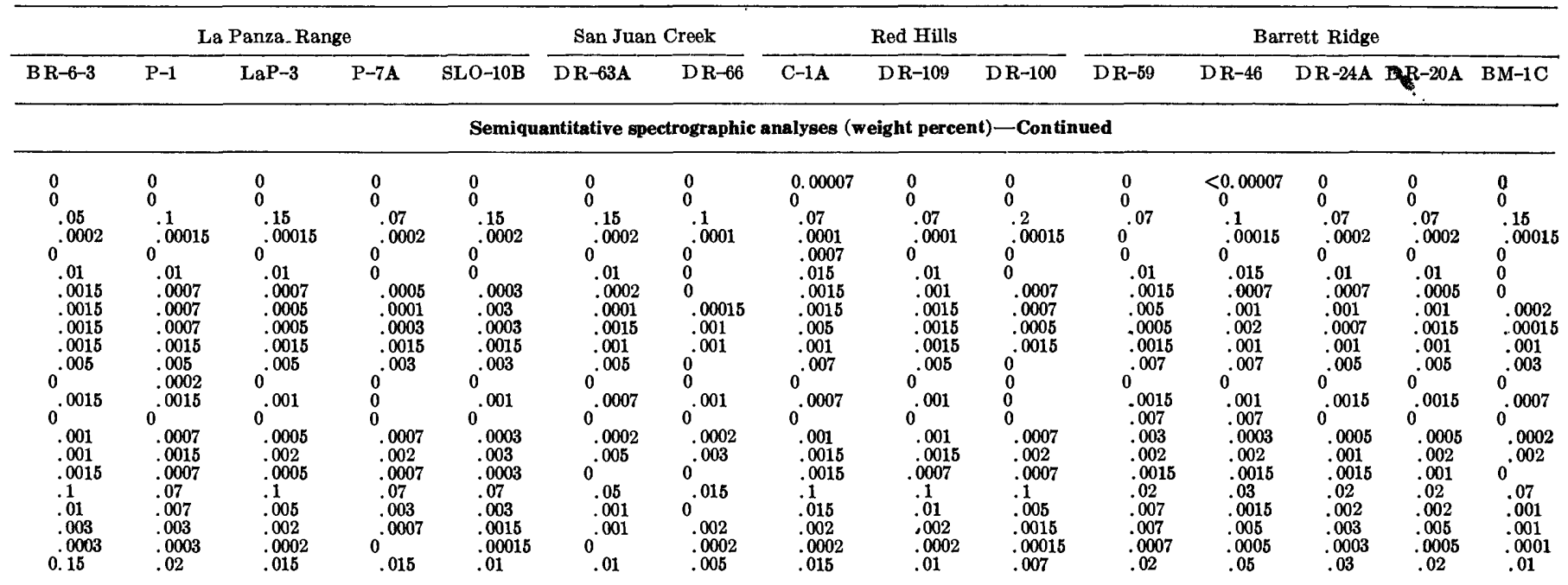

Norms (weight percent)-Continued

\begin{tabular}{|c|c|c|c|c|c|c|c|c|c|c|c|c|c|c|}
\hline $\begin{array}{l}19.0 \\
13.2 \\
31.7 \\
19.8\end{array}$ & $\begin{array}{l}30.3 \\
15.6 \\
27.4 \\
14.2\end{array}$ & $\begin{array}{l}29.8 \\
20.8 \\
26.4 \\
10.7\end{array}$ & $\begin{array}{r}38.0 \\
18.0 \\
24.9 \\
4.0\end{array}$ & $\begin{array}{r}33.2 \\
27.4 \\
23.9 \\
5.2\end{array}$ & $\begin{array}{r}37.5 \\
29.4 \\
22.3 \\
5.3\end{array}$ & $\begin{array}{r}32.0 \\
26.7 \\
34.8 \\
3.9\end{array}$ & $\begin{array}{l}\mathbf{1 4 . 7} \\
13.9 \\
28.5 \\
16.0\end{array}$ & $\begin{array}{l}23.4 \\
13.8 \\
26.7 \\
17.3\end{array}$ & $\begin{array}{l}32.2 \\
21.0 \\
23.2 \\
12.1\end{array}$ & $\begin{array}{r}25.0 \\
32.4 \\
20.6 \\
5.8\end{array}$ & $\begin{array}{r}33.0 \\
28.0 \\
21.3 \\
8.5\end{array}$ & $\begin{array}{l}37.1 \\
24.0 \\
21.4 \\
10.9\end{array}$ & $\begin{array}{r}40.7 \\
22.6 \\
20.4 \\
7.9\end{array}$ & $\begin{array}{l}29.1 \\
25.1 \\
30.8 \\
11.3\end{array}$ \\
\hline $\begin{array}{r}5.8 \\
3.7 \\
2.6 \\
1.5 \\
1.0 \\
1.2 \\
\text { (cc). } 6\end{array}$ & $\begin{array}{l}3.5 \\
1.9 \\
2.2 \\
1.2 \\
1.0 \\
2.7\end{array}$ & $\begin{array}{l}3.0 \\
1.8 \\
1.8 \\
1.1 \\
1.4 \\
3.4\end{array}$ & $\begin{array}{r}2.5 \\
2.5 \\
1.0 \\
.8 \\
2.3 \\
5.9 \\
\text { (cc). } 1\end{array}$ & $\begin{array}{l}2.2 \\
.8 \\
1.1 \\
1.6 \\
1.6 \\
4.3\end{array}$ & $\begin{array}{r}.7 \\
.3 \\
1.0 \\
.4 \\
.1 \\
2.8 \\
\text { (cc). } .1\end{array}$ & \begin{tabular}{c}
.5 \\
.9 \\
\hdashline .3 \\
.1 \\
.8 \\
$\cdots .$.
\end{tabular} & $\begin{array}{r}9.4 \\
4.9 \\
3.3 \\
2.3 \\
1.6 \\
4.4 \\
\text { (cc) } 1.0\end{array}$ & $\begin{array}{l}6.8 \\
3.4 \\
2.8 \\
1.5 \\
1.2 \\
3.0\end{array}$ & $\begin{array}{r}3.3 \\
2.4 \\
1.0 \\
.8 \\
.9 \\
2.9 \\
\text { (cc). }\end{array}$ & $\begin{array}{l}4.8 \\
3.7 \\
2.9 \\
1.3 \\
.1 \\
3.4\end{array}$ & $\begin{array}{r}7.4 \\
4.8 \\
1.3 \\
.4 \\
.7\end{array}$ & $\begin{array}{r}2.2 \\
2.2 \\
1.5 \\
.4 \\
.2\end{array}$ & $\begin{array}{r}1.7 \\
.6 \\
2.6 \\
1.0 \\
.3 \\
2.1 \\
\text { (cc). } 1\end{array}$ & $\begin{array}{r}1.5 \\
.6 \\
.9 \\
.4 \\
.1 \\
.1\end{array}$ \\
\hline 100.1 & 100.0 & 100.2 & 100.0 & 100.3 & 99.9 & 100.0 & 100.0 & 99.9 & 100.0 & 100.0 & 100.1 & 99.9 & 100.0 & 99.9 \\
\hline
\end{tabular}

Santa Lucia Range (Unpub, analyses furnished by R. C. Pearson. Specimens located and described

Santa Lucia Range (Compton, 1966, p. 280)

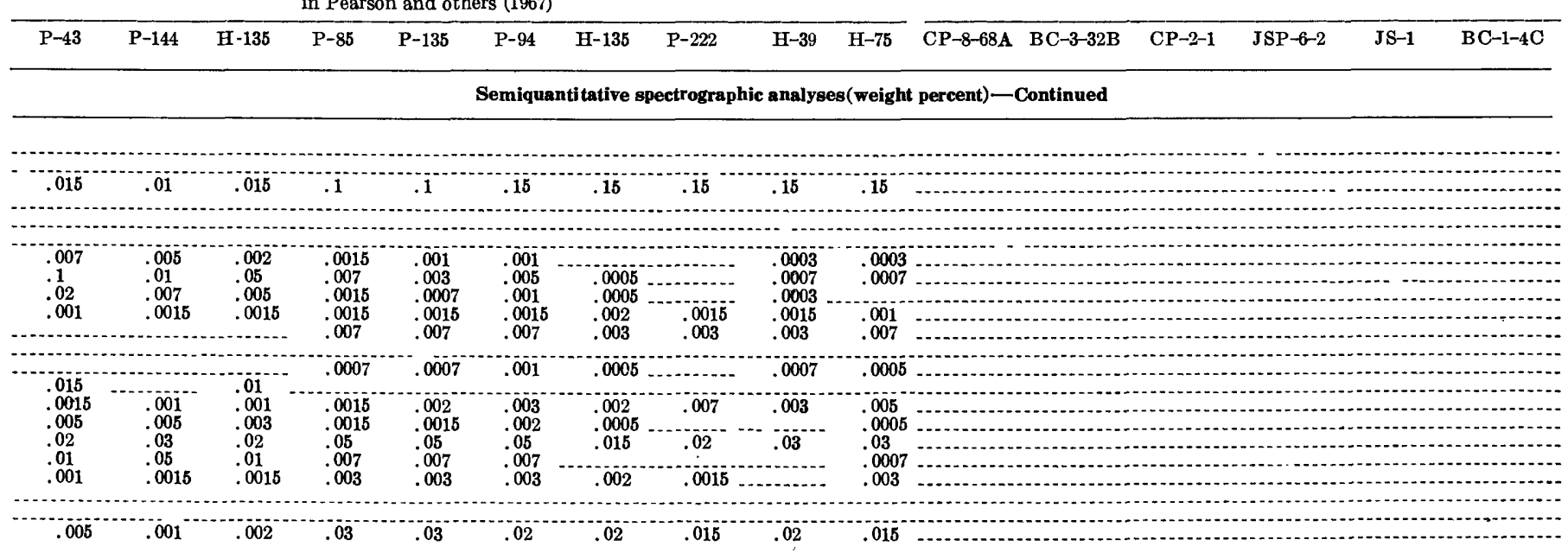

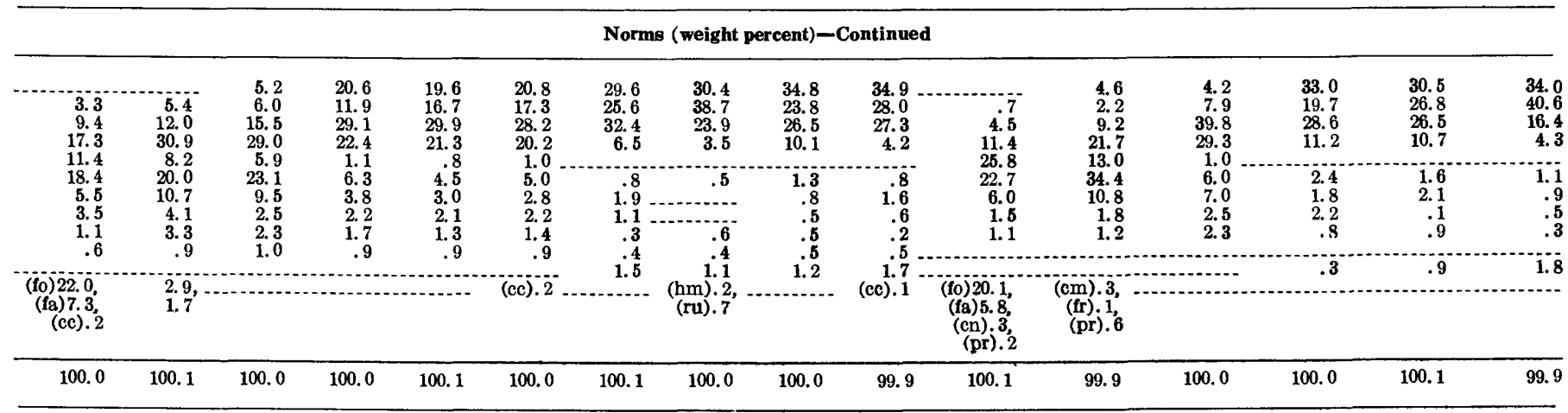


TABLE 30.-Chemical data on basement

\begin{tabular}{|c|c|c|c|c|c|c|c|c|c|}
\hline \multicolumn{8}{|c|}{ Gabilan Range } & \multicolumn{2}{|c|}{ Strok lale Mountain } \\
\hline & DR-570 & DR-584 & DR-566A & G-1B & G-1A & DR-576 & DR-546 & DR-145C & DR-14 2 \\
\hline \multicolumn{10}{|c|}{ Niggli numbers } \\
\hline $\begin{array}{l}\text { s1 } \\
\text { al } \\
\text { fm } \\
\text { c } \\
\text { glk }\end{array}$ & $\begin{array}{r}211.3 \\
34.2 \\
28.4 \\
21.3 \\
16.1 \\
46.8 \\
.3 \\
.5\end{array}$ & $\begin{array}{r}219.8 \\
35.0 \\
29.0 \\
19.7 \\
16.3 \\
54.6 \\
.3 \\
.5\end{array}$ & $\begin{array}{r}257.8 \\
36.7 \\
24.5 \\
17.3 \\
21.5 \\
71.7 \\
.4 \\
.5\end{array}$ & $\begin{array}{r}276.8 \\
39.8 \\
21.6 \\
16.5 \\
22.1 \\
88.3 \\
.4 \\
.4\end{array}$ & $\begin{array}{r}361.6 \\
43.8 \\
13.9 \\
12.5 \\
29.9 \\
142.1 \\
.5 \\
.4\end{array}$ & $\begin{array}{r}437.0 \\
48.3 \\
5.6 \\
10.7 \\
35.4 \\
195.6 \\
.5 \\
.4\end{array}$ & $\begin{array}{r}457.6 \\
48.2 \\
6.0 \\
69.5 \\
39.3 \\
200.3 \\
.6 \\
.2\end{array}$ & $\begin{array}{r}278.3 \\
39.0 \\
22.0 \\
16.1 \\
22.9 \\
86.7 \\
.4 \\
.4\end{array}$ & $\begin{array}{r}298.4 \\
41.8 \\
18.5 \\
15.6 \\
24.2 \\
101.6 \\
.4 \\
.4\end{array}$ \\
\hline
\end{tabular}

Modes (volume percent)

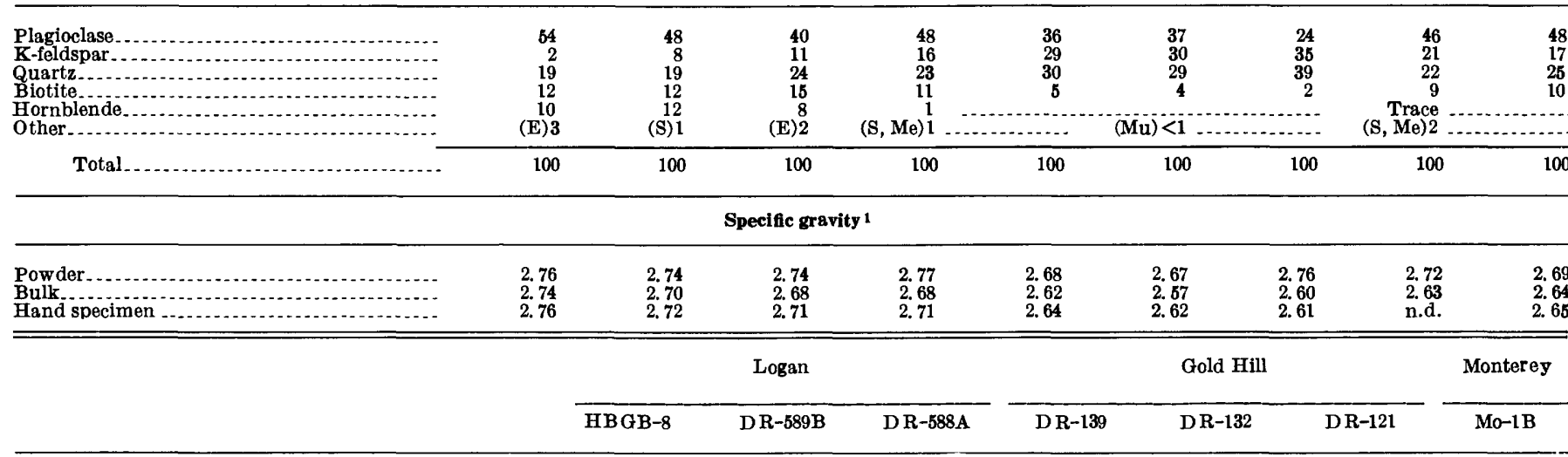

\begin{tabular}{|c|c|c|c|c|c|c|c|}
\hline \multicolumn{8}{|c|}{ Niggli numbers } \\
\hline 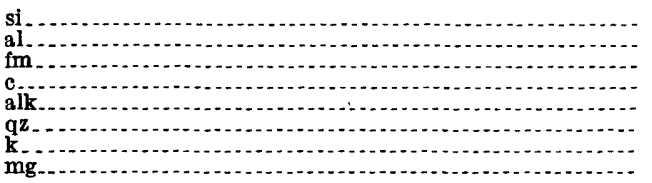 & $\begin{array}{r}122.6 \\
24.8 \\
45.7 \\
20.2 \\
9.4 \\
(-) 14.9 \\
.1\end{array}$ & $\begin{array}{r}133.6 \\
26.5 \\
40.9 \\
27.8 \\
4.8 \\
14.4 \\
.1 \\
.5\end{array}$ & $\begin{array}{r}143.1 \\
29.4 \\
36.3 \\
28.6 \\
5.7 \\
20.1 \\
.1 \\
.5\end{array}$ & $\begin{array}{r}105.8 \\
25.3 \\
35.8 \\
34.8 \\
4.1 \\
(-) 10.4 \\
.1 \\
.8\end{array}$ & $\begin{array}{r}142.2 \\
23.0 \\
48.4 \\
24.4 \\
4.1 \\
25.7 \\
.1 \\
.5\end{array}$ & $\begin{array}{r}148.2 \\
28.0 \\
39.3 \\
28.9 \\
3.8 \\
33.0 \\
.2 \\
.5\end{array}$ & $\begin{array}{r}405.6 \\
46.8 \\
9.4 \\
12.4 \\
31.4 \\
180.0 \\
.4 \\
.3\end{array}$ \\
\hline
\end{tabular}

\begin{tabular}{|c|c|c|c|c|c|c|}
\hline \multicolumn{7}{|c|}{ Modes (volume percent) } \\
\hline Plagioclase. & 53 & 46 & $\ldots$ & 33 & 54 & 41 \\
\hline $\begin{array}{l}\text { K-feldspar } \\
\text { Quartz } \\
\text { Biotite } \\
\text { Hornblende } \\
\text { Other }\end{array}$ & $\begin{array}{r}8 \\
35 \\
35 \\
(\mathrm{Me}) 2\end{array}$ & $\begin{array}{r}\text { Trace } \\
35 \\
(\mathrm{Me}) 2,(\mathrm{E}) 3 \\
(\mathrm{Ch}) 2\end{array}$ & (n) & 53 & $\begin{array}{r}12 \\
\text { Trace } \\
33 \\
(\mathbf{M e}) 1\end{array}$ & $\begin{array}{r}18 \\
\mathbf{3 6} \\
5\end{array}$ \\
\hline Total ......... & 100 & 100 & $\ldots$ & 100 & 100 & $\overline{100}$ \\
\hline \multicolumn{7}{|c|}{ Specific gravity } \\
\hline $\begin{array}{l}\text { Powder } \\
\text { Bulk } \\
\text { Hand specimen }\end{array}$ & $\begin{array}{l}2.83 \\
2.83 \\
2.81\end{array}$ & $\begin{array}{l}2.70 \\
2.86 \\
2.86\end{array}$ & $\begin{array}{l}2.94 \\
2.90 \\
\text { n.d. }\end{array}$ & $\begin{array}{l}2.93 \\
2.76 \\
2.99\end{array}$ & $\begin{array}{l}2.8 \\
2.84 \\
\text { n.d. }\end{array}$ & $\begin{array}{l}2.68 \\
2.56 \\
2.62\end{array}$ \\
\hline
\end{tabular}

Hand specimen.

\section{Gabilan Range: LOcALITIES FOR TABLE 30 (SEE PL. 1)}

DR-570. Hornblende-biotite quartz diorite. Center sec. 10, T. 19 S., R. 9 E., DR-584. Hornblende-biotite quartz diorite. NW. cor. sec. 26, T. 15 S., R. 5 E., DR-566A. Gonzales 15-min quad.

Benlende-biotite granodionite. Center Q-1B. Biotite granodiorite.

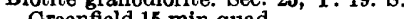
G-1A. Biotite quartz monzonite. Sec. 23, T. 19 S., R. 8 E., Bitterwater DR-576. Quartz monzonite. West of railroad tunnel on Metz-King City Road, Greenfield 15-min quad.
DR-546. Quartz monzonite. Elev 2,000 ft on Fremont Peak-State Park Road, Hollister 15-min quad.

DR-145C. Biotite granodiorite. NW1/4 sec. 11, T. 23 S., R. 13 E., Stockdale DR-142. Biotite granodiorite. NE $1 / 4$ sec. 3, T. 23 S., R. 13 E., Stockdale moun-
La Panza Range:
B R-6-3. Hornblende-biotite quartz diorite. NW1/4 sec. 5, T. 30 S., R. 16 E. B R-6-3. Hornblende-biotite quartz diorite. NW1/4 sec. 5, T. 30 S., R. 16 E.,
Pozo 15-min quad. $\begin{array}{ll}\text { P-1 } & \text { Biotite granodiorite. SE1/4 sec. 32, T. } 28 \text { S., R. } 14 \text { E., Pozo 15-min quad. } \\ \text { LaP-3. Blotite granodiorite. SE1/4 sec. 35, T.30 S., R. } 16 \text { E., La Panza 15-min }\end{array}$ P-7A. Biotite granodiorite. NW1/4 sec. 29, T. 29 S., R. 16 E., Pozo 15-min SLO-10B. Biotite quartz monzonite. SE1/4 sec. 2, T. 28 S., R. 14 E., San Luis Obispo 15-min quad.

San Juan Creek:
DR-63A. Biotite quartz monzonite. NW1/4 sec. 25, T. 30 S., R. 17 E., La Panza DR-66. Alaskite. SE $1 / 4$ sec. 25, T. 30 S., R. 17 E., La Panza 15-min quad.

Red Hills: "Mnartz diorite." NE $1 / 4$ sec. 5, T. 27 S., R. 16 E., Camatta Canyon C-1A. "Qnartz diorite." NE $1 / 4$ sec. 5, T. 27 S., R. 16 E., Camatta Canyon Hornblende-biotite quartz diorite.

DR-100. Gneissic hornblende-biotite granodiorite. SE1/4 sec. 5, T. 27 S., R. 16 E., Camatta Canyon 71/2-min quad. 
rocks of southern Coast Ranges-Continued

\begin{tabular}{|c|c|c|c|c|c|c|c|c|c|c|c|c|c|c|}
\hline \multicolumn{5}{|c|}{ La Panza Range } & \multicolumn{2}{|c|}{ San Juan Creek } & \multicolumn{3}{|c|}{ Red Hills } & \multicolumn{5}{|c|}{ Barrett Ridge } \\
\hline B R-6-3 & $\mathrm{P}-1$ & $\mathrm{LaP}-3$ & $\mathrm{P}-7 \mathrm{~A}$ & SLO-10B & DR-63A & DR-66 & $\mathrm{C}-1 \mathrm{~A}$ & DR-109 & DR-100 & D R-59 & DR-46 & DR-24A & DR-20A & BM-1C \\
\hline \multicolumn{15}{|c|}{ Niggli numbers-Continued } \\
\hline $\begin{array}{r}224.1 \\
35.7 \\
27.8 \\
18.5 \\
18.0 \\
52.2 \\
.3 \\
.4\end{array}$ & $\begin{array}{r}295.3 \\
41.0 \\
22.3 \\
15.9 \\
20.8 \\
112.0 \\
.4 \\
.4\end{array}$ & $\begin{array}{r}307.0 \\
42.7 \\
19.7 \\
14.0 \\
23.6 \\
11.7 \\
.4 \\
.4\end{array}$ & $\begin{array}{r}356.3 \\
45.6 \\
18.9 \\
11.5 \\
24.1 \\
160.1 \\
.4 \\
.4\end{array}$ & $\begin{array}{r}360.0 \\
47.2 \\
13.6 \\
10.4 \\
28.8 \\
144.8 \\
.5 \\
.5\end{array}$ & $\begin{array}{r}437.7 \\
50.0 \\
8.8 \\
7.6 \\
33.5 \\
203.6 \\
.6 \\
.3\end{array}$ & $\begin{array}{r}451.2 \\
48.7 \\
5.0 \\
5.4 \\
41.0 \\
187.3 \\
.4 \\
.4\end{array}$ & $\begin{array}{r}181.9 \\
33.9 \\
35.4 \\
15.8 \\
14.9 \\
22.2 \\
.3 \\
.5\end{array}$ & $\begin{array}{r}231.8 \\
36.6 \\
30.6 \\
16.2 \\
16.5 \\
65.7 \\
.3 \\
.5\end{array}$ & $\begin{array}{r}324.4 \\
42.7 \\
19.4 \\
15.1 \\
22.8 \\
133.2 \\
.5 \\
.5\end{array}$ & $\begin{array}{r}284.6 \\
38.5 \\
31.2 \\
5.5 \\
24.8 \\
85.4 \\
.6 \\
.4\end{array}$ & $\begin{array}{r}343.3 \\
37.5 \\
26.0 \\
10.0 \\
26.6 \\
137.1 \\
.6 \\
.2\end{array}$ & $\begin{array}{r}410.5 \\
41.5 \\
16.3 \\
14.4 \\
27.8 \\
199.2 \\
.5 \\
.5\end{array}$ & $\begin{array}{r}407.8 \\
42.5 \\
20.6 \\
10.7 \\
26.3 \\
202.5 \\
.5 \\
.3\end{array}$ & $\begin{array}{r}377 . \\
44 . \\
10 . \\
12 . \\
32 . \\
143 .\end{array}$ \\
\hline \multicolumn{15}{|c|}{ Modes (volume percent)-Continued } \\
\hline $\begin{array}{r}61 \\
3 \\
15 \\
13 \\
8\end{array}$ & $\begin{array}{r}43 \\
18 \\
27 \\
12 \\
<1\end{array}$ & $\begin{array}{r}47 \\
15 \\
27 \\
<11\end{array}$ & $\begin{array}{l}44 \\
13 \\
33 \\
10\end{array}$ & $\begin{array}{r}34 \\
36 \\
25 \\
5\end{array}$ & $\begin{array}{r}27 \\
39 \\
32 \\
2\end{array}$ & $\begin{array}{r}28 \\
35 \\
35 \\
2\end{array}$ & (1) & $\begin{array}{r}55 \\
4 \\
21 \\
10\end{array}$ & & & & & & \\
\hline 100 & 100 & 100 & 100 & 100 & 100 & 100 & (n.................. & 100 & $\bar{\cdots}$ & $\ldots$ & $\ldots$ & $\cdots$ & & \\
\hline \multicolumn{15}{|c|}{ Speciffe gravity - Continued } \\
\hline $\begin{array}{l}2.76 \\
2.69 \\
\text { n.d. }\end{array}$ & $\begin{array}{l}2.69 \\
2.67 \\
2.70\end{array}$ & $\begin{array}{l}2.70 \\
2.65 \\
2.68\end{array}$ & $\begin{array}{l}2.68 \\
2.61 \\
2.66\end{array}$ & $\begin{array}{l}2.66 \\
2.56 \\
2.63\end{array}$ & $\begin{array}{l}2.68 \\
2.67 \\
2.61\end{array}$ & $\begin{array}{l}2.61 \\
2.58 \\
2.61\end{array}$ & $\begin{array}{c}2.76 \\
2.70 \\
\text { n.d. }\end{array}$ & $\begin{array}{r}2.78 \\
2.70 \\
2.75\end{array}$ & $\begin{array}{l}2.71 \\
2.66 \\
2.70\end{array}$ & $\begin{array}{l}2.75 \\
2.68 \\
\text { n.d. }\end{array}$ & $\begin{array}{l}2.70 \\
2.68 \\
\text { n.d. }\end{array}$ & $\begin{array}{l}2.71 \\
2.68 \\
\text { n.d. }\end{array}$ & $\begin{array}{l}2.70 \\
2.66 \\
\text { n.d. }\end{array}$ & $\begin{array}{l}2.6 \\
2.6 \\
\text { n.d }\end{array}$ \\
\hline
\end{tabular}

Santa Lucia Range (Unpub. analyses furnished by R. C. Pearson. Specimens located and described

Santa Lucia Range (Compton, 1966, p. 280)

\begin{tabular}{|c|c|c|c|c|c|c|c|c|c|c|c|c|c|c|c|}
\hline \\
\hline$P-43$ & P-144 & H-135 & P-85 & P-135 & P-94 & H-135 & $\mathrm{P}-222$ & $\mathrm{H}-39$ & $\mathrm{H}-75$ & CP-8-68A & $\mathrm{BC}-3-32 \mathrm{~B}$ & CP-2-1 & $J S P-6-2$ & JS-1 & BC-1-4C \\
\hline \multicolumn{16}{|c|}{ Niggli numbers-Continued } \\
\hline $\begin{array}{r}83.3 \\
9.2 \\
70.5 \\
17.8 \\
2.6 \\
(-) 26.8 \\
.3 \\
.8\end{array}$ & $\begin{array}{r}102.2 \\
18.4 \\
52.9 \\
24.5 \\
4.2 \\
(-) 14.5 \\
.3 \\
.6\end{array}$ & $\begin{array}{r}127.1 \\
20.7 \\
49.9 \\
23.6 \\
5.8 \\
4.1 \\
.3 \\
.7\end{array}$ & $\begin{array}{r}229.4 \\
33.9 \\
28.3 \\
21.3 \\
16.5 \\
63.2 \\
.3 \\
.5\end{array}$ & $\begin{array}{r}241.9 \\
36.7 \\
23.0 \\
20.7 \\
19.6 \\
63.6 \\
.3 \\
.4\end{array}$ & $\begin{array}{r}243.6 \\
35.6 \\
24.6 \\
20.7 \\
19.2 \\
67.0 \\
.4 \\
.5\end{array}$ & $\begin{array}{r}379.2 \\
45.6 \\
12.1 \\
8.5 \\
33.9 \\
143.8 \\
.4 \\
.2\end{array}$ & $\begin{array}{r}435.2 \\
49.1 \\
4.3 \\
5.7 \\
40.8 \\
71.8 \\
.6 \\
.4\end{array}$ & $\begin{array}{r}403.9 \\
46.4 \\
9.4 \\
13.6 \\
30.6 \\
181.4 \\
.5 \\
.4\end{array}$ & $\begin{array}{r}433.2 \\
46.8 \\
10.1 \\
7.5 \\
35.6 \\
190.8 \\
.5 \\
.3\end{array}$ & $\begin{array}{r}83.1 \\
5.4 \\
66.5 \\
27.1 \\
1.0 \\
(-) 21.0 \\
.1 \\
.8\end{array}$ & $\begin{array}{r}115.9 \\
13.0 \\
59.9 \\
24.7 \\
2.8 \\
4.7 \\
.2 \\
.7\end{array}$ & $\begin{array}{r}168.4 \\
34.9 \\
28.7 \\
20.4 \\
16.1 \\
4.0 \\
.2 \\
.4\end{array}$ & $\begin{array}{r}360.3 \\
39.8 \\
21.3 \\
12.0 \\
26.9 \\
152.8 \\
.4 \\
.3\end{array}$ & $\begin{array}{r}375.8 \\
45.5 \\
11.9 \\
11.9 \\
30.7 \\
153.0 \\
.5 \\
.4\end{array}$ & $\begin{array}{r}437.3 \\
48.5 \\
9.3 \\
5.5 \\
36.8 \\
190.2\end{array}$ \\
\hline
\end{tabular}

Modes (volume percent)-Continued

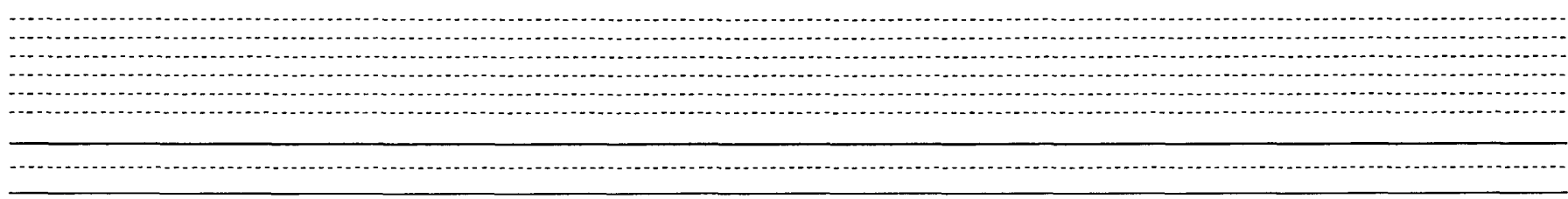

Specific gravity-Continued

(1)

\section{Barrett Ridge:}

DR-59. Quartzo-feldspathic gneiss. Sec. 9, T. 31 S., R. 18 E., Branch Moun-

DR-46. Quartzo-feldspathic gneiss. SE $1 / 4$ sec. 15, T. 31 S., R. 18 E., Branch Mountain 15-min quad.

D R-24A. Quartzo-feldspathic gneiss. SE1/4 sec. 25, T. 31 S., R. 18 E., Caliente Mountain 15-min quad.

DR-20A. Quartzo-feldspathic gneiss. NE1/4 sec. 26, T. 31 S., R. 18 E., Branch

BM-1C. Alaskite. NE $1 / 4$ sec. 26, T. 31 S., R. 18 E., Branch Mountain 15-min quad

HB GB-8. Hornblende gabbro, Logan quarry (Reid, 1902).

D R-589B. Hornblende quartz gabbro. Logan quarry. San Juan Bautista 15-

min quad.
DR-588A. Hornblende quartz gabbro. About 1 mile SE. of Anzar Lake, San Juan Bautista 15-min quad.

DR-139. Anorthositic gabbro. About $2 \frac{1}{4}$ miles S. $38^{\circ}$ E. of NW. cor. Cholame D R-132. Hornblende quartz gabbro. West slope of Gold Hill. Cholame Valley DR-121. Hornblende quartz gabbro. West slope of Gold Hill. Cholame Valley
$71 / 2-$ min quad.
Monterey:
Mo-1B. Biotite quartz monzonite. Huckleberry Hill quarry, Monterey PeninSanta Lucia Range: Monterey 15-min quad.

P-43. Hornblendite.

P-144. Hornblende gabbro.

H-135. Gabbro.

P-82. Granodiorite.

P-135. Granodiorite.

P-94. Quartz diorite.

P-222. Pegmatitic granite.

P-39. Piotite granite.

H-76. Garnetiferous biotite granite.

Santa Lucia Range:

BC-3-32B. Plagioclase-pyroxene hornblendite, Bear Canyon 15-min quad

CP-2-1. Quartz diorite, Cone Peak 15-min quad.

JSP-6-2. Granodiorite, Junipero Serra Peak 15-min quad.

JS-1. Quartz monzonite, Junipero Serra Peak 15-min quad.

BC-1-4C. Granite, Bear Canyon 15-min quad. 
TABLE 31.-Chemical data on basement rocks of [Chemical analyses by P. L. D. Elmore, Lowell Artis, S. D. Botts, Gillison Chloe, J. L. Glenn, James Kelsey, and Hezekiah Smith. Semiquantitative spectrographic analyses
midpoints of these brackets, 1, 0.7, 0.5, 0.3, 0.2, 0.15, 0.1, etc. The precision of a reported value is approximately plus or minus one bracket at 68 percent, or two brackets where $\mathrm{La}$ or Ce found: $\mathrm{Pr}, \mathrm{Sm}$, Eu. Norms: symbols for other minerals are cc $=$ calcite, $\mathrm{hm}=$ hematite. Modes: symbols for other minerals are $\mathrm{S}=$ sphene, Me=metallic specimen submitted for chemical analysis; hand specimen, is bulk determination by water submersion method on larger sample]

TRANSVERSE RANGES

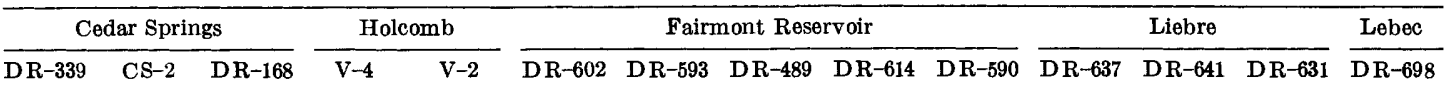

\begin{tabular}{|c|c|c|c|c|c|c|c|c|c|c|c|c|c|c|}
\hline \multicolumn{15}{|c|}{ Chemical analyses (weight percent) } \\
\hline 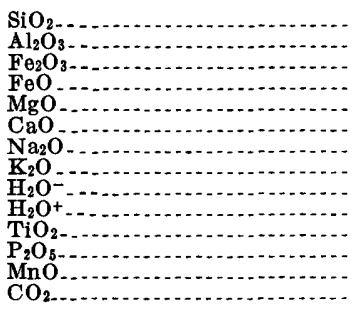 & $\begin{aligned} 60.0 \\
17.8 \\
2.2 \\
4.0 \\
3.1 \\
5.7 \\
3.6 \\
1.9 \\
.18 \\
.82 \\
.18 \\
.36 \\
.06 \\
<.05\end{aligned}$ & $\begin{array}{r}64.5 \\
17.2 \\
1.6 \\
2.4 \\
1.6 \\
4.4 \\
4.1 \\
2.5 \\
.08 \\
.74 \\
.78 \\
.28 \\
<.05\end{array}$ & $\begin{array}{r}64.9 \\
17.0 \\
2.0 \\
1.9 \\
1.5 \\
3.9 \\
4.2 \\
2.5 \\
.13 \\
.82 \\
.76 \\
.29 \\
.08 \\
<.05\end{array}$ & $\begin{array}{r}62.9 \\
17.3 \\
2.1 \\
2.5 \\
2.1 \\
4.8 \\
3.6 \\
2.4 \\
.11 \\
.88 \\
.76 \\
.80 \\
.07 \\
<.05\end{array}$ & $\begin{array}{r}64.5 \\
16.5 \\
2.0 \\
2.2 \\
1.9 \\
4.6 \\
3.7 \\
2.1 \\
.06 \\
1.0 \\
.89 \\
.28 \\
.07 \\
<.05\end{array}$ & $\begin{array}{r}62.3 \\
17.1 \\
1.7 \\
2.9 \\
1.9 \\
5.2 \\
4.1 \\
2.0 \\
.06 \\
.90 \\
1.1 \\
.32 \\
.12 \\
.16\end{array}$ & $\begin{array}{r}63.3 \\
17.1 \\
1.8 \\
2.6 \\
1.8 \\
4.8 \\
4.0 \\
2.1 \\
.06 \\
1.0 \\
.95 \\
.28 \\
.06 \\
<.05\end{array}$ & $\begin{array}{c}65.8 \\
16.6 \\
1.4 \\
2.5 \\
1.7 \\
4.3 \\
3.4 \\
2.6 \\
.08 \\
1.1 \\
.84 \\
.13 \\
.10 \\
<.05\end{array}$ & $\begin{array}{r}67.0 \\
16.3 \\
1.2 \\
2.0 \\
1.4 \\
3.4 \\
3.6 \\
3.0 \\
.06 \\
1.0 \\
.67 \\
.22 \\
.10 \\
<.05\end{array}$ & $\begin{array}{c}72.5 \\
14.0 \\
.92 \\
.80 \\
.65 \\
2.2 \\
3.0 \\
4.6 \\
.09 \\
.65 \\
.81 \\
.16 \\
.08 \\
<.05\end{array}$ & $\begin{array}{c}60.8 \\
17.5 \\
2.0 \\
3.4 \\
2.6 \\
5.1 \\
3.6 \\
2.3 \\
.14 \\
1.4 \\
.82 \\
.27 \\
.12 \\
<.05\end{array}$ & $\begin{array}{r}61.0 \\
17.7 \\
1.8 \\
3.3 \\
2.4 \\
5.4 \\
4.0 \\
2.2 \\
.08 \\
.79 \\
.87 \\
.28 \\
.05 \\
<.05\end{array}$ & $\begin{array}{r}67.0 \\
16.2 \\
1.4 \\
1.9 \\
1.5 \\
3.6 \\
3.3 \\
3.4 \\
.08 \\
.72 \\
.58 \\
.18 \\
.10 \\
<.05\end{array}$ & $\begin{array}{c}67.8 \\
15.7 \\
.31 \\
2.9 \\
1.6 \\
3.3 \\
3.2 \\
3.2 \\
.08 \\
.73 \\
.54 \\
.15 \\
.10 \\
.30\end{array}$ \\
\hline Total & 99.90 & 100.18 & 99.98 & 99.82 & 99.80 & 99.86 & 99.85 & 100.05 & 99.95 & 99.96 & 100.05 & 99.87 & 99.96 & 99.91 \\
\hline \multicolumn{15}{|c|}{ Semiguantitative spectrographic analyses (weight percent) } \\
\hline $\begin{array}{l}\mathrm{B} \\
\mathrm{Ba} \\
\mathrm{Be} \\
\mathrm{Ce} \\
\mathrm{Co} \\
\mathrm{Cr} \\
\mathrm{Cu} \\
\mathrm{Ga} \\
\mathrm{L} \mathrm{a} \\
\mathrm{Mo} \\
\mathrm{Nb} \\
\mathrm{Nd} \\
\mathrm{Ni} \\
\mathrm{Pb} \\
\mathrm{S} \mathrm{C} \\
\mathrm{Sr} \\
\mathrm{V} \\
\mathrm{Y} \\
\mathrm{Y} \mathrm{b} \\
\mathrm{Zr}\end{array}$ & $\begin{array}{l}0.0007 \\
.05 \\
.0002 \\
0 \\
.003 \\
.002 \\
.0015 \\
.002 \\
.005 \\
0.002 \\
.00 \\
.0015 \\
.001 \\
.002 \\
.1 \\
.015 \\
.005 \\
.0003 \\
.015\end{array}$ & $\begin{array}{l}0.001 \\
.07 \\
.0005 \\
.015 \\
.001 \\
.0007 \\
.0005 \\
.002 \\
.007 \\
0.002 \\
.007 \\
.0001 \\
.002 \\
.001 \\
.07 \\
.007 \\
.002 \\
.0002 \\
.03\end{array}$ & $\begin{array}{l}0.001 \\
.07 \\
.0003 \\
.015 \\
.001 \\
.0007 \\
.0007 \\
.003 \\
.007 \\
0 \\
.0015 \\
.007 \\
.00015 \\
.002 \\
.001 \\
.1 \\
.007 \\
.002 \\
.0002 \\
.02\end{array}$ & $\begin{array}{l}0.001 \\
.07 \\
.0003 \\
0 \\
.0015 \\
.001 \\
.0005 \\
.003 \\
.007 \\
.0003 \\
.002 \\
.007 \\
.0007 \\
.002 \\
.0015 \\
.1 \\
.01 \\
.003 \\
.0002 \\
.03\end{array}$ & $\begin{array}{l}0.0015 \\
.07 \\
.0003 \\
0.0015 \\
.0015 \\
.0015 \\
.0005 \\
.002 \\
.003 \\
.0002 \\
.002 \\
0 \\
.0007 \\
.002 \\
.0015 \\
.1 \\
.01 \\
.003 \\
.0003 \\
.03\end{array}$ & $\begin{array}{l}0 \\
.05 \\
.0003 \\
.01 \\
.001 \\
.0007 \\
.0015 \\
.0015 \\
.005 \\
0 \\
.003 \\
.007 \\
.0001 \\
.0015 \\
.0007 \\
.1 \\
.01 \\
.003 \\
.0002 \\
.02\end{array}$ & $\begin{array}{l}0 \\
.07 \\
.0002 \\
.01 \\
.001 \\
.0005 \\
.0015 \\
.002 \\
.003 \\
0 \\
.002 \\
0 \\
.0001 \\
.0015 \\
.0007 \\
.1 \\
.01 \\
.002 \\
.0002 \\
.02\end{array}$ & $\begin{array}{l}0.0007 \\
.1 \\
.0003 \\
.01 \\
.001 \\
.001 \\
.0005 \\
.002 \\
.005 \\
00 \\
.003 \\
0.0002 \\
.002 \\
.001 \\
.1 \\
.007 \\
.005 \\
.0003 \\
.02\end{array}$ & $\begin{array}{l}0 \\
.1 \\
.0002 \\
0.0007 \\
.0003 \\
.002 \\
.0015 \\
.005 \\
0.0015 \\
0^{.0015} \\
0 \\
.002 \\
.0005 \\
.07 \\
.007 \\
.0015 \\
.00015 \\
.02\end{array}$ & \begin{tabular}{l}
0.001 \\
.15 \\
.00015 \\
0 \\
.0003 \\
.0001 \\
.0015 \\
.0015 \\
0 \\
0 \\
.001 \\
\hdashline 0.003 \\
.003 \\
.05 \\
.005 \\
.001 \\
.0001 \\
.015
\end{tabular} & $\begin{array}{l}0 \\
.07 \\
.00015 \\
.01 \\
.0015 \\
.001 \\
.002 \\
.0015 \\
.005 \\
0.0015 \\
00 \\
.0007 \\
.0015 \\
.0015 \\
.1 \\
.015 \\
.003 \\
.0002 \\
.015\end{array}$ & $\begin{array}{l}0 \\
.05 \\
.00015 \\
.01 \\
.0015 \\
.0007 \\
.003 \\
.002 \\
.005 \\
0.001 \\
.00 \\
.0005 \\
.0015 \\
.001 \\
.1 \\
.015 \\
.002 \\
.0002 \\
.03\end{array}$ & $\begin{array}{l}0.001 \\
.1 \\
.00015 \\
.01 \\
.001 \\
.0005 \\
.0007 \\
.0015 \\
.005 \\
0.0015 \\
.0015 \\
.0002 \\
.002 \\
.0007 \\
.07 \\
.01 \\
.002 \\
.0002 \\
.01\end{array}$ & $\begin{array}{l}0.001 \\
.05 \\
.0003 \\
.007 \\
.0007 \\
.001 \\
.0007 \\
.002 \\
.005 \\
0.0015 \\
.00 \\
.0003 \\
.002 \\
.0007 \\
.05 \\
.005 \\
.002 \\
.00015 \\
.01\end{array}$ \\
\hline \multicolumn{15}{|c|}{ Norms (weight percent) } \\
\hline $\begin{array}{l}\text { Q... } \\
\text { or } \\
\text { ab.- } \\
\text { an }\end{array}$ & $\begin{array}{l}13.7 \\
11.4 \\
30.8 \\
26.2\end{array}$ & $\begin{array}{l}19.4 \\
14.9 \\
34.9 \\
20.1\end{array}$ & $\begin{array}{l}21.0 \\
14.9 \\
35.9 \\
17.6\end{array}$ & $\begin{array}{l}19.6 \\
14.4 \\
30.8 \\
22.1\end{array}$ & $\begin{array}{l}22.9 \\
12.6 \\
31.7 \\
21.3\end{array}$ & $\begin{array}{l}17.4 \\
12.0 \\
35.1 \\
22.6\end{array}$ & $\begin{array}{l}19.2 \\
12.6 \\
34.3 \\
22.3\end{array}$ & $\begin{array}{l}23.6 \\
15.5 \\
29.1 \\
20.7\end{array}$ & $\begin{array}{l}25.3 \\
17.9 \\
30.8 \\
15.6\end{array}$ & $\begin{array}{r}32.3 \\
27.4 \\
25.6 \\
9.9\end{array}$ & $\begin{array}{l}15.7 \\
13.8 \\
30.9 \\
23.9\end{array}$ & $\begin{array}{l}13.9 \\
13.1 \\
34.2 \\
24.1\end{array}$ & $\begin{array}{l}24.9 \\
20.3 \\
28.2 \\
16.8\end{array}$ & $\begin{array}{l}27.0 \\
19.1 \\
27.8 \\
13.6\end{array}$ \\
\hline $\begin{array}{l}\text { wo } \\
\text { on } \\
\text { fs } \\
\text { mt } \\
\text { il } \\
\text { ap } \\
\text { other }\end{array}$ & $\begin{array}{r}7.8 \\
5.4 \\
3.2 \\
.3 \\
.9 \\
.3\end{array}$ & $\begin{array}{r}7.0 \\
1.8 \\
2.3 \\
1.5 \\
.7 \\
.4\end{array}$ & $\begin{array}{r}3.8 \\
.7 \\
2.9 \\
1.5 \\
.7 \\
1.0\end{array}$ & $\begin{array}{r}5.3 \\
1.8 \\
3.1 \\
1.5 \\
.7 \\
.8\end{array}$ & $\begin{array}{l}4.8 \\
1.1 \\
2.9 \\
1.7 \\
.7 \\
.5 \\
. . .\end{array}$ & $\begin{array}{r}.1 \\
4.8 \\
2.4 \\
2.5 \\
2.1 \\
.8 \\
\text { cc. }) .4\end{array}$ & $\begin{array}{r}4.5 \\
1.9 \\
2.6 \\
1.8 \\
.7 \\
.2\end{array}$ & $\begin{array}{l}4.3 \\
3.1 \\
2.1 \\
.7 \\
.3 \\
.7\end{array}$ & $\begin{array}{l}3.5 \\
1.8 \\
1.8 \\
1.3 \\
.5 \\
1.5\end{array}$ & $\begin{array}{r}1.6 \\
.3 \\
1.3 \\
.6 \\
.4 \\
.5\end{array}$ & $\begin{array}{l}6.6 \\
3.5 \\
2.9 \\
1.6 \\
.7 \\
.5\end{array}$ & $\begin{array}{r}.5 \\
6.0 \\
3.3 \\
2.6 \\
1.7 \\
.7 \\
. .-\end{array}$ & $\begin{array}{l}3.8 \\
1.6 \\
2.0 \\
1.1 \\
.4 \\
1.0\end{array}$ & $\begin{array}{r}4.0 \\
4.4 \\
.5 \\
1.0 \\
.4 \\
2.1 \\
\text { (ce.). }\end{array}$ \\
\hline Total. & 100.0 & 100.0 & 100.0 & 100.1 & 100.2 & 100.2 & 100.1 & 100.1 & 100.0 & 99.9 & 100.1 & 100.1 & 100.1 & 100.1 \\
\hline \multicolumn{15}{|c|}{ Niggli numbers } \\
\hline 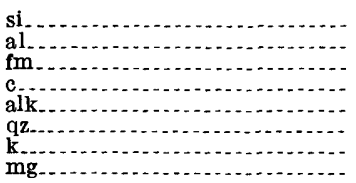 & $\begin{array}{r}193.7 \\
33.9 \\
31.2 \\
19.7 \\
15.2 \\
33.0 \\
.3 \\
.5\end{array}$ & $\begin{array}{r}247.9 \\
39.0 \\
21.5 \\
18.1 \\
21.4 \\
62.3 \\
.3 \\
.4\end{array}$ & $\begin{array}{r}256.9 \\
39.7 \\
21.4 \\
16.5 \\
22.4 \\
67.2 \\
.3 \\
.4\end{array}$ & $\begin{array}{r}231.1 \\
37.5 \\
25.2 \\
18.9 \\
18.5 \\
57.3 \\
.3 \\
.5\end{array}$ & $\begin{array}{r}249.9 \\
37.7 \\
24.2 \\
19.1 \\
19.1 \\
73.5 \\
.3 \\
.5\end{array}$ & $\begin{array}{r}226.3 \\
36.6 \\
24.1 \\
20.2 \\
19.1 \\
50.0 \\
.2 \\
.4\end{array}$ & $\begin{array}{r}237.1 \\
37.7 \\
23.5 \\
19.3 \\
19.5 \\
58.9 \\
.3 \\
.4\end{array}$ & $\begin{array}{r}262.1 \\
39.0 \\
23.0 \\
18.4 \\
19.7 \\
83.2 \\
.3 \\
.4\end{array}$ & $\begin{array}{r}286.3 \\
41.1 \\
20.3 \\
15.6 \\
23.1 \\
94.0 \\
.4 \\
.4\end{array}$ & $\begin{array}{r}384.7 \\
43.8 \\
12.7 \\
12.5 \\
31.0 \\
160.7 \\
.5 \\
.4\end{array}$ & $\begin{array}{r}209.2 \\
35.5 \\
28.7 \\
18.8 \\
17.1 \\
41.0 \\
.3 \\
.5\end{array}$ & $\begin{array}{r}208.7 \\
35.7 \\
26.5 \\
19.8 \\
18.1 \\
36.4 \\
.3 \\
.5\end{array}$ & $\begin{array}{r}282.3 \\
40.2 \\
20.9 \\
16.3 \\
22.6 \\
91.8 \\
.4 \\
.5\end{array}$ & $\begin{array}{r}294.0 \\
40.1 \\
22.2 \\
15.3 \\
22.3 \\
104.8 \\
.4 \\
.5\end{array}$ \\
\hline
\end{tabular}

See explanation at end of table. 
Transverse Ranges and Mojave Desert

by Chris Heropoulos. Results are to be identified with geometric brackets whose boundaries are $1.2,0.83,0.56,0.38,0.26,0.18,0.12$, etc., but are reported arbitrarily as at 95 percent confidence. Looked for but not found: Ag, As, Au, Bi, Cd, Ge, Hf, Hg, In, Li, Pd, Pt, Re, Sb, Sn, Ta, Te, Th, Tl, U, W, Zn. Also looked for but not found opaque minerals, $\mathbf{E}=$ epidote, $\mathrm{Mu}=$ muscovite. Specific gravity: powder, determined by air pycnometer from part of split for chemical analysis; bulk, determined from

\begin{tabular}{|c|c|c|c|c|c|c|c|c|c|c|c|c|c|c|}
\hline \multicolumn{9}{|c|}{ TRANVERSE RANGES-Continued } & \multicolumn{6}{|c|}{ MOJAVE } \\
\hline Lebec-Continued & \multicolumn{8}{|c|}{ Miscellaneous } & \multicolumn{3}{|c|}{ Lovejoy Butte } & \multicolumn{2}{|c|}{ Hi Vista } & Miscellaneous \\
\hline D R-686 DR-690 & $\mathrm{DR}-460$ & DR-479 & D R-745 & D R-810 & DR-814 & BBL & D R-728 & DR-726 & $\underset{316 \mathrm{~A}}{\mathrm{DR}}$ & D R-315 & $\underset{319 A}{\mathrm{DR}-}$ & $\underset{321 B}{\text { DR- }}$ & D R-298 & DR-280 DR-349 \\
\hline
\end{tabular}

Chemical analyses (weight percent)-Continued

\begin{tabular}{|c|c|c|c|c|c|c|c|c|c|c|c|c|c|c|c|c|}
\hline $\begin{array}{c}68.0 \\
16.2 \\
.26 \\
2.4 \\
1.0 \\
3.2 \\
3.9 \\
3.4 \\
.08 \\
.65 \\
.54 \\
.16 \\
.07 \\
.19\end{array}$ & $\begin{array}{c}68.5 \\
16.0 \\
.45 \\
2.5 \\
1.0 \\
3.2 \\
3.5 \\
3.4 \\
.06 \\
.55 \\
.50 \\
.15 \\
.07 \\
.11\end{array}$ & $\begin{array}{c}58.0 \\
18.6 \\
3.1 \\
3.0 \\
2.0 \\
6.1 \\
4.3 \\
2.4 \\
.14 \\
.71 \\
.95 \\
.29 \\
.18 \\
<.05\end{array}$ & $\begin{array}{c}58.3 \\
17.4 \\
2.2 \\
4.2 \\
3.3 \\
5.8 \\
3.5 \\
2.3 \\
.07 \\
1.8 \\
.76 \\
.19 \\
.17 \\
<.05\end{array}$ & $\begin{array}{c}62.4 \\
18.6 \\
1.1 \\
3.0 \\
1.6 \\
4.2 \\
4.1 \\
2.6 \\
.07 \\
.90 \\
.77 \\
.34 \\
.10 \\
<.05\end{array}$ & $\begin{array}{c}66.7 \\
16.0 \\
1.5 \\
1.9 \\
1.7 \\
3.3 \\
3.4 \\
3.5 \\
.20 \\
.90 \\
.54 \\
.17 \\
.10 \\
<.05\end{array}$ & $\begin{array}{c}66.7 \\
16.0 \\
1.3 \\
2.0 \\
1.5 \\
3.7 \\
3.5 \\
3.5 \\
.10 \\
.86 \\
.54 \\
.15 \\
.07 \\
<.05\end{array}$ & $\begin{array}{c}71.1 \\
15.0 \\
.90 \\
1.0 \\
.69 \\
2.2 \\
3.7 \\
3.8 \\
.16 \\
.75 \\
.68 \\
.02 \\
.09 \\
<.05\end{array}$ & $\begin{array}{c}72.5 \\
15.3 \\
.62 \\
.44 \\
.38 \\
2.1 \\
4.6 \\
3.2 \\
.11 \\
.51 \\
.15 \\
.05 \\
.10 \\
<.05\end{array}$ & $\begin{array}{c}75.6 \\
13.2 \\
.24 \\
.96 \\
.17 \\
.87 \\
3.7 \\
4.4 \\
.04 \\
.54 \\
.11 \\
.04 \\
.07 \\
<.05\end{array}$ & $\begin{array}{c}73.5 \\
14.9 \\
.38 \\
1.2 \\
.55 \\
2.2 \\
3.7 \\
2.2 \\
.11 \\
.81 \\
.13 \\
.12 \\
.06 \\
<.05\end{array}$ & $\begin{array}{c}73.9 \\
14.2 \\
.30 \\
1.0 \\
.48 \\
2.0 \\
3.7 \\
3.2 \\
.13 \\
.74 \\
.20 \\
.06 \\
.06 \\
<.05\end{array}$ & $\begin{array}{c}74.2 \\
14.1 \\
.45 \\
.68 \\
.34 \\
1.3 \\
3.3 \\
3.5 \\
.14 \\
.75 \\
.80 \\
.12 \\
.05 \\
<.05\end{array}$ & $\begin{array}{c}65.0 \\
16.6 \\
1.7 \\
2.5 \\
1.8 \\
4.4 \\
3.6 \\
2.5 \\
.05 \\
.75 \\
.78 \\
.24 \\
.06 \\
<.05\end{array}$ & $\begin{array}{c}69.8 \\
15.5 \\
1.1 \\
1.3 \\
1.0 \\
3.0 \\
3.7 \\
3.4 \\
.14 \\
.60 \\
.16 \\
.14 \\
.06 \\
<.05\end{array}$ & $\begin{array}{r}65.5 \\
16.5 \\
2.0 \\
1.8 \\
1.5 \\
3.8 \\
4.2 \\
2.6 \\
.20 \\
.72 \\
.47 \\
.28 \\
.06 \\
<.05\end{array}$ & $\begin{array}{c}73.8 \\
14.0 \\
.65 \\
.68 \\
.44 \\
1.4 \\
3.5 \\
4.1 \\
.12 \\
.44 \\
.66 \\
.13 \\
.11 \\
<.05\end{array}$ \\
\hline 100.05 & 99.99 & 99.77 & 99.99 & 99.78 & 99.91 & 99.92 & 100.09 & 100.06 & 99.94 & 99.86 & 99.97 & 99.73 & 99.98 & 99.90 & 99.63 & 100.03 \\
\hline \multicolumn{17}{|c|}{ Semiguantitative spectrographic analyses (weight percent)-Continued } \\
\hline $\begin{array}{l}0.0015 \\
.1 \\
.0002 \\
.01 \\
.0005 \\
.0005 \\
.0007 \\
.002 \\
.005 \\
0 \\
.0015 \\
0 \\
0 \\
.002 \\
.0003 \\
.05 \\
.005 \\
.0015 \\
.00007 \\
.015\end{array}$ & $\begin{array}{l}0.001 \\
.1 \\
.0003 \\
0 \\
.0005 \\
.0005 \\
.0005 \\
.003 \\
.003 \\
0.0015 \\
.00 \\
0 \\
.003 \\
.0007 \\
.05 \\
.003 \\
.002 \\
.00015 \\
.02\end{array}$ & $\begin{array}{l}0.0007 \\
.15 \\
.00015 \\
0 \\
.002 \\
.0002 \\
.01 \\
.002 \\
.005 \\
0.001 \\
.001 \\
0 \\
.003 \\
.0015 \\
.15 \\
.015 \\
.005 \\
.0003 \\
.01\end{array}$ & $\begin{array}{l}0.0007 \\
.07 \\
.0003 \\
0 \\
.003 \\
.003 \\
.005 \\
.002 \\
.003 \\
0.001 \\
0.00 \\
.003 \\
.0015 \\
.002 \\
.1 \\
.015 \\
.003 \\
.0002 \\
.015\end{array}$ & $\begin{array}{l}0 \\
.1 \\
.0003 \\
.015 \\
.001 \\
.0005 \\
.005 \\
.003 \\
.007 \\
0.005 \\
.005 \\
.007 \\
.0002 \\
.003 \\
.001 \\
.1 \\
.007 \\
.003 \\
.0002 \\
.02\end{array}$ & $\begin{array}{l}0 \\
.07 \\
.0003 \\
.01 \\
.001 \\
.001 \\
.0015 \\
.002 \\
.005 \\
00 \\
.002 \\
0.0007 \\
.003 \\
.0007 \\
.07 \\
.01 \\
.002 \\
.0002 \\
.015\end{array}$ & $\begin{array}{l}0 \\
.07 \\
0.0002 \\
.001 \\
.001 \\
.003 \\
.0015 \\
.003 \\
0.001 \\
00 \\
.0007 \\
.003 \\
.0007 \\
.05 \\
.007 \\
.0015 \\
.00015 \\
.015\end{array}$ & $\begin{array}{l}0.001 \\
.07 \\
.0005 \\
.01 \\
.0005 \\
.0002 \\
.0015 \\
.002 \\
.005 \\
0.001 \\
.001 \\
0 \\
.005 \\
.0003 \\
.05 \\
.003 \\
.001 \\
.0001 \\
.015\end{array}$ & $\begin{array}{l}0.001 \\
.15 \\
.0002 \\
0 \\
0 \\
0 \\
.0005 \\
.0015 \\
0 \\
0 \\
.0015 \\
0.002 \\
0.002 \\
.07 \\
.001 \\
0 \\
0 \\
.01\end{array}$ & \begin{tabular}{l}
0.001 \\
.1 \\
.0003 \\
0 \\
0 \\
.0001 \\
.0003 \\
.0015 \\
0 \\
0.001 \\
.001 \\
\hdashline 0.0 \\
.003 \\
.0003 \\
.007 \\
0.003 \\
.003 \\
.0002 \\
.01
\end{tabular} & $\begin{array}{l}0.001 \\
.15 \\
.00015 \\
0 \\
0 \\
.0007 \\
.0015 \\
.002 \\
.003 \\
0.001 \\
0.002 \\
.0002 \\
.003 \\
.07 \\
.001 \\
.001 \\
.0001 \\
.01\end{array}$ & $\begin{array}{l}0.0015 \\
.1 \\
.0002 \\
0 \\
0 \\
.0001 \\
.003 \\
.002 \\
0 \\
0 \\
.0015 \\
0.005 \\
.005 \\
.05 \\
.0015 \\
.0015 \\
.00015 \\
.01\end{array}$ & $\begin{array}{l}0.0015 \\
.07 \\
.0005 \\
0 \\
0 \\
.0003 \\
.0015 \\
.002 \\
.003 \\
0.0015 \\
0 \\
0 \\
.005 \\
0 \\
.03 \\
.001 \\
.0015 \\
.00015 \\
.007\end{array}$ & $\begin{array}{l}0.001 \\
.07 \\
.0003 \\
.01 \\
.0015 \\
.001 \\
.0015 \\
.003 \\
.005 \\
0.002 \\
.002 \\
.0005 \\
.003 \\
.001 \\
.07 \\
.007 \\
.002 \\
.0002 \\
.02\end{array}$ & $\begin{array}{l}0.0007 \\
.07 \\
.0003 \\
0.0007 \\
.0005 \\
.002 \\
.002 \\
.005 \\
0.001 \\
.001 \\
.00015 \\
.005 \\
.0005 \\
.07 \\
.005 \\
.001 \\
.0001 \\
.015\end{array}$ & $\begin{array}{l}0.001 \\
.07 \\
.0003 \\
0 \\
.001 \\
.0005 \\
.001 \\
.003 \\
.007 \\
00 \\
.0015 \\
0 \\
0 \\
.003 \\
.0007 \\
.1 \\
.007 \\
.0015 \\
.00015 \\
.02\end{array}$ & $\begin{array}{l}0.0015 \\
.07 \\
.0005 \\
.01 \\
.00015 \\
.0007 \\
.0015 \\
.005 \\
0.002 \\
.0 \\
0.005 \\
.0003 \\
.03 \\
.001 \\
.002 \\
.0002 \\
.015\end{array}$ \\
\hline \multicolumn{17}{|c|}{ Norms (weight percent)-Continued } \\
\hline $\begin{array}{l}23.5 \\
20.2 \\
33.2 \\
13.7\end{array}$ & $\begin{array}{l}26.1 \\
20.2 \\
29.8 \\
14.3\end{array}$ & $\begin{array}{r}8.8 \\
14.3 \\
36.8 \\
24.6 \\
1.7\end{array}$ & $\begin{array}{l}10.8 \\
13.9 \\
30.2 \\
25.5 \\
1.1\end{array}$ & $\begin{array}{l}16.8 \\
15.5 \\
35.1 \\
18.8\end{array}$ & $\begin{array}{l}24.0 \\
20.9 \\
29.1 \\
15.4\end{array}$ & $\begin{array}{l}22.6 \\
20.9 \\
29.9 \\
17.6\end{array}$ & $\begin{array}{l}29.5 \\
22.6 \\
31.6 \\
10.9\end{array}$ & $\begin{array}{l}28.6 \\
19.0 \\
39.1 \\
10.1\end{array}$ & $\begin{array}{r}34.8 \\
26.2 \\
31.5 \\
4.1\end{array}$ & $\begin{array}{l}38.0 \\
13.1 \\
31.6 \\
10.2\end{array}$ & $\begin{array}{r}35.0 \\
19.1 \\
31.6 \\
9.6\end{array}$ & $\begin{array}{r}39.1 \\
20.9 \\
28.3 \\
5.7\end{array}$ & $\begin{array}{l}22.3 \\
14.9 \\
30.7 \\
20.4\end{array}$ & $\begin{array}{l}27.4 \\
20.3 \\
31.6 \\
14.1\end{array}$ & $\begin{array}{l}21.4 \\
15.6 \\
36.0 \\
17.2\end{array}$ & $\begin{array}{r}34.7 \\
24.4 \\
29.8 \\
6.1\end{array}$ \\
\hline $\begin{array}{r}2.5 \\
3.5 \\
.4 \\
1.0 \\
.4 \\
1.1 \\
\text { (cc.). } 4\end{array}$ & $\begin{array}{r}2.5 \\
3.5 \\
.7 \\
1.0 \\
.4 \\
1.4 \\
\text { (cc.). } \\
\end{array}$ & $\begin{array}{r}5.0 \\
1.7 \\
4.5 \\
1.8 \\
.7\end{array}$ & $\begin{array}{r}8.4 \\
5.1 \\
3.3 \\
1.5 \\
.5 \\
-. .-\end{array}$ & $\begin{array}{l}4.0 \\
3.6 \\
1.6 \\
1.5 \\
.8 \\
2.2\end{array}$ & $\begin{array}{l}4.3 \\
1.6 \\
2.2 \\
1.0 \\
.4 \\
1.0\end{array}$ & $\begin{array}{l}3.8 \\
1.9 \\
1.9 \\
1.0 \\
.4 \\
.1\end{array}$ & $\begin{array}{l}1.7 \\
.1 \\
1.3 \\
1.3 \\
.9\end{array}$ & $\begin{array}{l}1.0 \\
.2 \\
.9 \\
.3 \\
.1 \\
.6\end{array}$ & $\begin{array}{r}.4 \\
1.5 \\
.4 \\
.2 \\
.1 \\
.9\end{array}$ & $\begin{array}{l}1.4 \\
1.8 \\
.6 \\
.2 \\
.3 \\
2.7\end{array}$ & $\begin{array}{r}1.2 \\
1.4 \\
.4 \\
.4 \\
.1 \\
1.2\end{array}$ & $\begin{array}{r}.9 \\
1.5 \\
.3 \\
2.8 \\
(\mathrm{hm} .) .4\end{array}$ & $\begin{array}{l}4.5 \\
2.0 \\
2.5 \\
1.5 \\
.6 \\
.6\end{array}$ & $\begin{array}{l}2.5 \\
1.3 \\
1.6 \\
.3 \\
.3 \\
.6\end{array}$ & $\begin{array}{l}3.8 \\
1.0 \\
2.9 \\
.9 \\
.7 \\
.6 \\
0\end{array}$ & $\begin{array}{r}1.1 \\
.6 \\
1.3 \\
.3 \\
1.6 \\
(\mathrm{hm} .)^{2} .2\end{array}$ \\
\hline 99.9 & 100.2 & 99.9 & 100.3 & 99.9 & 99.9 & 100.1 & 100.1 & 99.9 & 100.1 & 99.9 & 100.0 & 99.9 & 100.0 & 100.0 & 100.1 & 100.1 \\
\hline \multicolumn{17}{|c|}{ Niggli numbers-Continued } \\
\hline $\begin{array}{r}299.9 \\
42.1 \\
16.6 \\
15.1 \\
26.2 \\
94.9 \\
.4 \\
.4\end{array}$ & $\begin{array}{r}305.8 \\
42.1 \\
17.8 \\
15.3 \\
24.8 \\
106.5 \\
.4 \\
.4\end{array}$ & $\begin{array}{r}186.1 \\
35.2 \\
25.6 \\
21.0 \\
18.3 \\
12.9 \\
.3 \\
.4\end{array}$ & $\begin{array}{r}184.7 \\
32.5 \\
32.4 \\
19.7 \\
15.4 \\
23.1 \\
.3 \\
.5\end{array}$ & $\begin{array}{r}232.0 \\
40.8 \\
21.6 \\
16.7 \\
20.9 \\
48.2 \\
.3 \\
.4\end{array}$ & $\begin{array}{r}279.9 \\
39.6 \\
22.4 \\
14.8 \\
23.2 \\
87.1 \\
.4 \\
.5\end{array}$ & $\begin{array}{r}278.3 \\
39.4 \\
20.6 \\
16.5 \\
23.5 \\
84.4 \\
.4 \\
.5\end{array}$ & $\begin{array}{r}358.6 \\
44.6 \\
13.2 \\
11.9 \\
30.3 \\
137.4 \\
.4 \\
.4\end{array}$ & $\begin{array}{r}376.6 \\
46.8 \\
7.7 \\
11.7 \\
33.8 \\
141.5 \\
.3 \\
.4\end{array}$ & $\begin{array}{r}461.0 \\
47.4 \\
7.9 \\
5.7 \\
39.0 \\
205.0 \\
.4 \\
.2\end{array}$ & $\begin{array}{r}401.9 \\
48.0 \\
11.8 \\
12.9 \\
27.3 \\
192.8 \\
.3 \\
.4\end{array}$ & $\begin{array}{r}411.3 \\
46.6 \\
10.2 \\
11.9 \\
31.3 \\
186.0 \\
.4 \\
.4\end{array}$ & $\begin{array}{r}447.3 \\
50.1 \\
8.8 \\
8.4 \\
32.7 \\
216.3 \\
.4 \\
.4\end{array}$ & $\begin{array}{r}253.1 \\
38.1 \\
23.8 \\
18.4 \\
19.8 \\
73.9 \\
.3 \\
.4\end{array}$ & $\begin{array}{r}323.8 \\
42.4 \\
16.0 \\
14.9 \\
26.7 \\
117.0 \\
.4 \\
.4\end{array}$ & $\begin{array}{r}263.9 \\
39.2 \\
21.3 \\
16.4 \\
23.1 \\
71.6 \\
.3 \\
.4\end{array}$ & $\begin{array}{r}420.2 \\
47.0 \\
10.3 \\
8.5 \\
34.2 \\
183.3 \\
.4 \\
.4\end{array}$ \\
\hline
\end{tabular}


TABLE 31.-Chemical data on basement rocks of

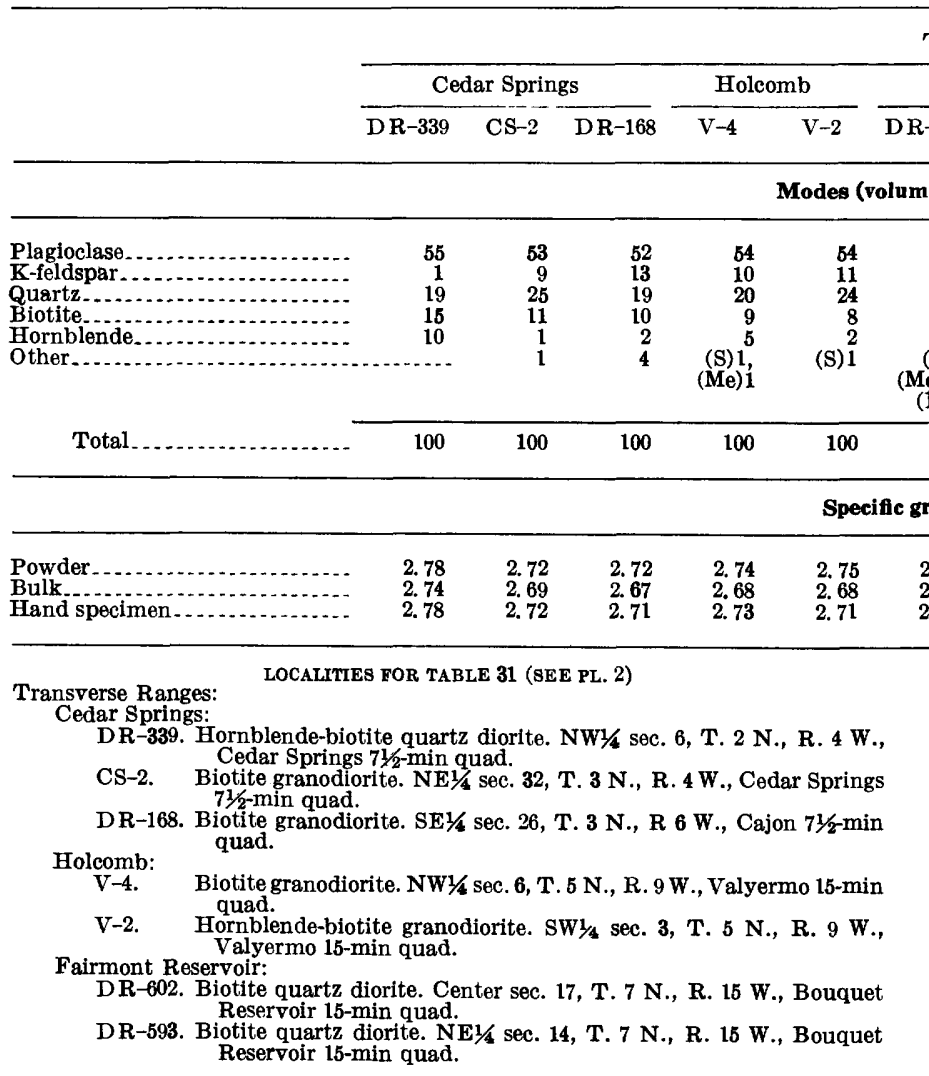

Conclusions about individual masses cannot be drawn confidently from these limited data, but in total the data offer a pattern for the whole province. The Coast Ranges and Transverse Ranges are treated separately, for they are physically and structurally separate. The central and southern Coast Ranges are in part also treated separately. This is more a subdivision of convenience than of nature, but some characteristics suggest that the central Coast Ranges granitic rocks are more closely related to each other thin to the bulk of the granitic rocks of the southern Coast Ranges.

In some of the graphic plots, chemical data on ultramafic rocks of the Santa Lucia Range, quartzo-feldspathic gneisses of Barrett Ridge, and hornblende quartz gabbro of the Gold Hill and Logan areas are shown separately. The ultramafic rocks of the Santa Lucia Range tend to distort comparisons with other batholithic areas where I do not have data on comparable rocks. The Barrett Ridge rocks probably are paragneisses and thus not comparable. The gabbros of Gold Hill and Logan are probably "orphan" rocks that do not belong to the Salinian block. Their unusual chemical characteristics also tend to skew data plots.
TPANSVERSE RANGES

\begin{tabular}{|c|c|c|}
\hline Fairmont Reservoir & Liebre & \\
\hline
\end{tabular}

(nercent)

\begin{tabular}{|c|c|c|c|c|c|c|c|c|}
\hline $\begin{array}{r}55 \\
5 \\
23 \\
12 \\
1 \\
\text { (S), } \\
\text { (e) } 1 \text {, }\end{array}$ & $\begin{array}{r}55 \\
6 \\
21 \\
12 \\
4 \\
4 \\
(\mathrm{~S}) 1, \\
(\mathrm{Me}) 1\end{array}$ & $\begin{array}{r}50 \\
8 \\
29 \\
11 \\
1 \\
\text { (E)1 }\end{array}$ & $\begin{array}{r}47 \\
12 \\
29 \\
10 \\
\left(\mathrm{CS}^{\mathrm{E}} 1 ;\right. \\
\text { (E) } 1\end{array}$ & $\begin{array}{r}32 \\
28 \\
34 \\
6 \\
6 \\
(\mathrm{Mu})<1\end{array}$ & $\begin{array}{r}57 \\
3 \\
21 \\
13 \\
6\end{array}$ & $\begin{array}{r}59 \\
3 \\
19 \\
15 \\
4\end{array}$ & $\begin{array}{r}46 \\
17 \\
26 \\
8 \\
2 \\
\text { (S) } 1\end{array}$ & $\begin{array}{r}41 \\
17 \\
27 \\
13 \\
2\end{array}$ \\
\hline 100 & 100 & 100 & 100 & 100 & 100 & 100 & 100 & 100 \\
\hline
\end{tabular}

$\begin{array}{lllllllll}2.80 & 2.80 & 2.77 & 2.72 & 2.68 & 2.72 & 2.74 & 2.67 & 2.70 \\ 2.69 & 2.69 & 2.67 & 2.65 & 2.67 & 2.72 & 2.69 & 2.65 & 2.67 \\ 2.73 & 2.72 & 2.71 & 2.67 & 2.62 & 2.73 & 2.73 & 2.69 & 2.68\end{array}$

\footnotetext{
DR-489. Biotite granodiortie. NW1/4 sec. 30, T. 7 N., R. 14 W., Bouquet DR-614. Biotite granodiorite. SE $1 / 4$ sec. 12, T. 7 N., R. 16 W., Burnt Peak $71 / 2-$-min quad.
DR-590. Biotite quartz monzonite. SW1/4 sec. 12, T. 7 N., R. 15 W., Bouquet otite quartz monzonite. Reservoir 15-min quad.

D R-637. Hornblende-biotite quartz diorite. SW1/4 sec. 5, T. 7 N., R. 17 W.,

Liebre Mountain 71/2-min quad.
DR-641. Biotite quartz diorite. SW1/4 sec. 28 , T. 8 N., R. 18 W., Lebec 71/2-min quad.
DR-631. Biotite granodionite. SW1/4 sec. 32, T. 8 N., R. 17 W., Liebre Mountain $7 \frac{1}{2}$-min quad.

DR-698. Biotite granodiorite, NW1/4 sec. 35, T. 9 N., R. 20 W., Frazier DR-686. Biotite granodiorite. NE $1 / 4$ sec. 31, T. 9 N., R. 19 W., Frazier Mountain $7 \frac{1}{2}$-min quad.
}

Liebre:

Lebec:

\section{VARIATION DIAGRAMS}

Several different variation diagrams have been proposed, but probably the most commonly used is still the simple silica-variation diagram (Harker diagram) in which the weight percentage of each oxide is plotted against the weight percentage of silica. Figure 32 presents such diagrams for the rocks described in this report. If the ultramafic rocks of the Santa Lucia Range, the gneisses of Barrett Ridge, and the hornblende quartz gabbros of Gold Hill and Logan are omitted-for reasons already discussed-the trends are rather well defined for each of the oxides. The field for $\mathrm{TiO}_{2}$ seems more "diffuse" largely because the vertical scale is more exaggerated than the scale used for the other oxides.

The plotted trends are so well defined that lines approximating least-squares fits can be plotted by eye with a fair degree of confidence. Just to be sure of the trends, however, a least-squares line fit computer program was run that also gave standard deviation of the spread of the data from the least-squares lines. The lines on figure 30 are plotted from the computer data. Understandably there were no great surprises in the least-squares lines, and there were no significant differences between the 
Transverse Ranges and Mojave Desert-Continued

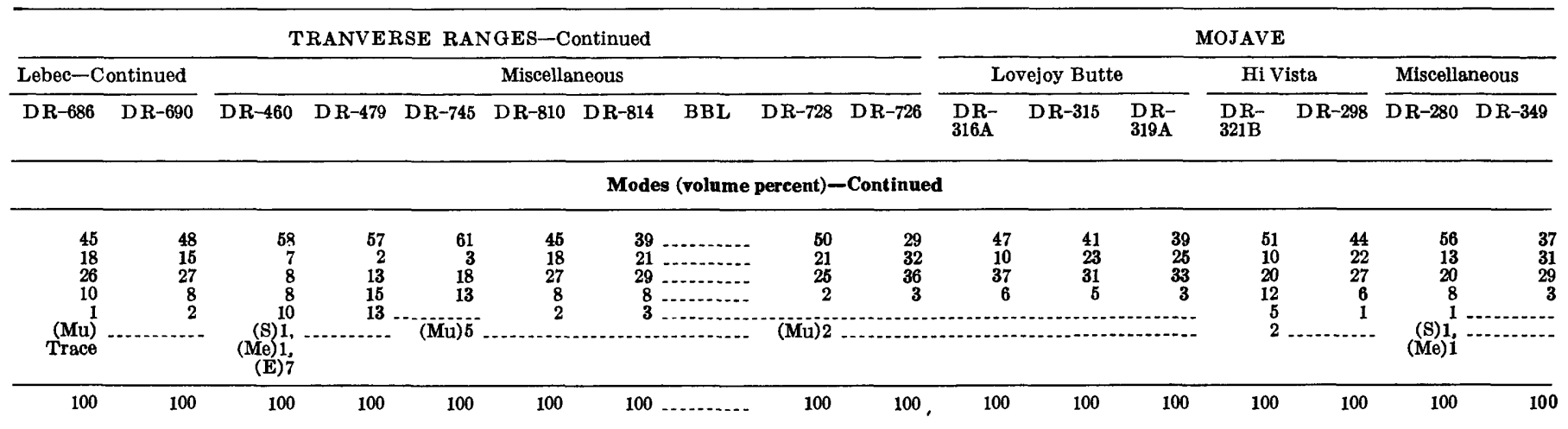

\begin{tabular}{ccccccccccccccccc}
\hline 110 \\
\hline 110 \\
\hline 10
\end{tabular}

DR-690. Biotite granodiorite. SW1/4 sec. 25, T. 9. N., R. 20 W., Frazier Miscellaneous:

DR-460. Biotite-hornblende granodionite of Acton (near diorite field) NE1/4NW1/4, sec. 31, T. 5 N., R. 12 W., Acton 15-min quad. DR-479. Hornblende-biotite quartz diorite gneiss of Bouquet Reservoir 15-min quad. SE cor. sec. 18, T. 6 N., R. $14 \mathrm{~W}$.
DR-745. Muscovite-bearing biotite-quartz diorite of

DR-746. Muscovite-bearing biotite-quartz diorite of Mount Abel. NE1/4 sec. 34, T. 9 N., R. 22 W., Sawmill Mountain 71/2-min quad.

iotite granodiorite of Mutau and Piru Creeks, NW1/4 sec. 36,

T. 7 N., R. 21 W., Lockwood Valley $71 / 2-$ min quad.
DR-814. Biotite granodiorite of Mutau and Piru Creeks, SE cor. sec. 25,

T. 7 N., R. 21 W., Lockwood Valley $71 / 2$-min quad.

BBL. Biotite quartz monzonite; near west end of Big Bear Lake on highway.

Muscovite-bearing granodiorite of Mount Abel and Pinos. NE1/4 sec. 32, T. 9 N., R. 22 W., Sawmill Mountain 71/2-min quad. laskite of Brush Mountain. NW1/ sec. $10, T .9$ N., 22 W Eagle Rest Peak 71\%-min quad.

Coast and Transverse Ranges suites. $\mathrm{Al}_{2} \mathrm{O}_{3}$ and $\mathrm{Na}_{2} \mathrm{O}$ are somewhat lower in general in the Coast Ranges, and total $\mathrm{Fe}$ as $\mathrm{FeO}$ and $\mathrm{MgO}$ are a bit higher. The $\mathrm{K}_{2} \mathrm{O}$ data suggest at first glance rather marked trend differences between the Coast and Transverse Ranges suites. This difference is probably due to the inclusion of published analyses of very felsic rocks in the Coast Ranges. K-feldspar-rich alaskitic and aplitic rocks are also present in the Transverse Ranges, and analysis of these rocks would have made the trends more similar. If the three analyses with the highest $\mathrm{K}_{2} \mathrm{O}$ values in the Coast Ranges suite are omitted, the two suites are much more similar. This is a good example of the caution necessary in making comparisons on the basis of gross sampling where bias may be introduced either by locality or rock type. This problem should be kept in mind throughout the ensuing discussion.

Figure 33 shows the computer-calculated least-squares line plots for granitic suites of the Coast Ranges, Transverse Ranges, Sierra Nevada, and the southern California batholith. To facilitate comparison, the standard deviation of the spread from the calculated line is given. This is a measure of how well the least-squares line fits
Mojave Desert:

Lovejoy Butte:

DR-316A. Muscovite-bearing biotite granodiorite. SW1/4 sec. 12, T. 6 N., R. $10 \mathrm{~W}$., Littlerock 71/2-min quad.

DR-315. Biotite granodiorite. Center of north boundary sec. 29, T. 6 N., R. 9 W., Lovejoy Buttes $71 / 2$-min quad.
DR-319A. Quartz monzonite. NW1/4 sec. 32, T. 7 N., R. 9 W., (Piute Butte), Hi Vista: Hi Vista $71 / 2$-min quad.

DR-321B. Hornblende-biotite granodiorite. SW1/4 sec. 15, T. 7 N., R. 9 W., DR-298. Biotite granodiorite. SW $1 / 4$ sec. 9, T. 6 N., R. 7 W., (Gray MounDR-298. Biotite granodiorite. SW1/4 sec. $9, \mathrm{~T} .6 \mathrm{~N}$
tain), Shadow Mountains 15 -min quad.

Miscellaneous: Biotite granodiorite. SE $1 / 4$ sec. 29 , T. 6 N., R. 5 W., Victorville

DR-349. Quartz monzonite. SE cor. sec. 13, T. 3 N., R. 4 W., Lake Arrowhead 15-min quad.

the data points-the lower the standard deviation, the better the trend.

Some of the oxides, particularly $\mathrm{Al}_{2} \mathrm{O}_{3}, \mathrm{MgO}, \mathrm{CaO}$, and to some extent $\mathrm{K}_{2} \mathrm{O}$, provide some interesting and identifiable differences between the suites. Probably the most general relation is the similarity of chemical trends of the southern California batholith rocks and those of the western Sierra Nevada, and the difference of those suites from the granitic rocks of the eastern Sierra Nevada. The Coast and Transverse Ranges suites have characteristics distinct from these other suites. For example, they compare closely with eastern Sierra rocks in $\mathrm{CaO}$, and to a lesser extent $\mathrm{MgO}$. They appear to be intermediate between the trends of the eastern Sierra and western Sierra-southern California batholith with respect to $\mathrm{K}_{2} \mathrm{O}$ (if the highly $\mathrm{K}_{2} \mathrm{O}$-rich Coast Range values are discounted). The Coast and Transverse Ranges are somewhat higher in $\mathrm{Al}_{2} \mathrm{O}_{3}$ than the other granitic suites. $\mathrm{Na}_{2} \mathrm{O}$ has its usual "near horizontal" trend, very typical for normal granitic suites. Iron has an almost mirror image reversal of $\mathrm{FeO}$ and $\mathrm{Fe}_{2} \mathrm{O}_{3}$ for all the suites, suggesting a regional difference in degree of oxidation which $I$ do not understand at present. 
74 PETROGRAPHIC, CHEMICAL STUDY, GRANITIC AND GNEISSIC ROCKS, SAN ANDREA FAULT, CALIF.
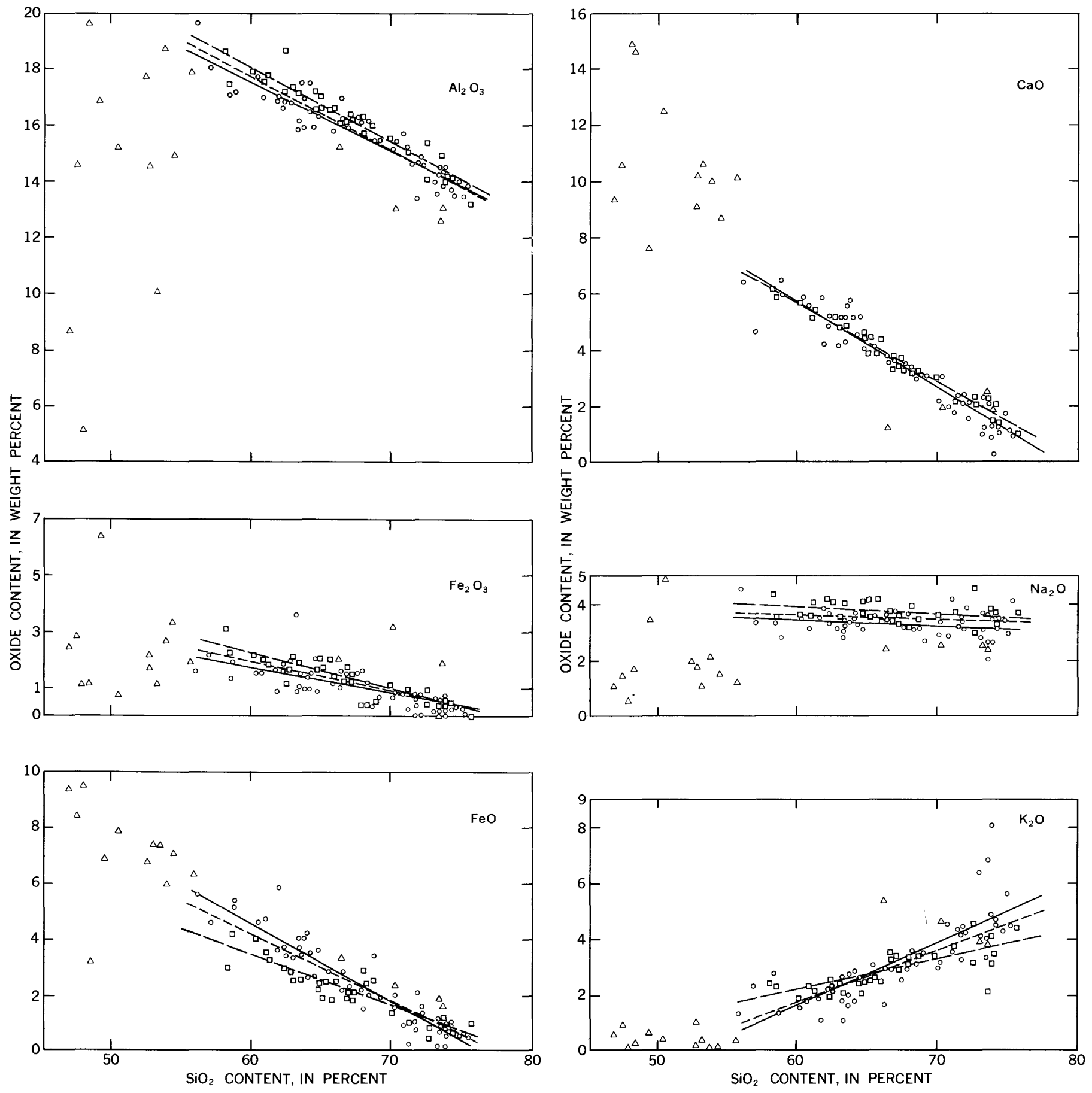

FIGURE 32.-Silica-variation diagrams. 

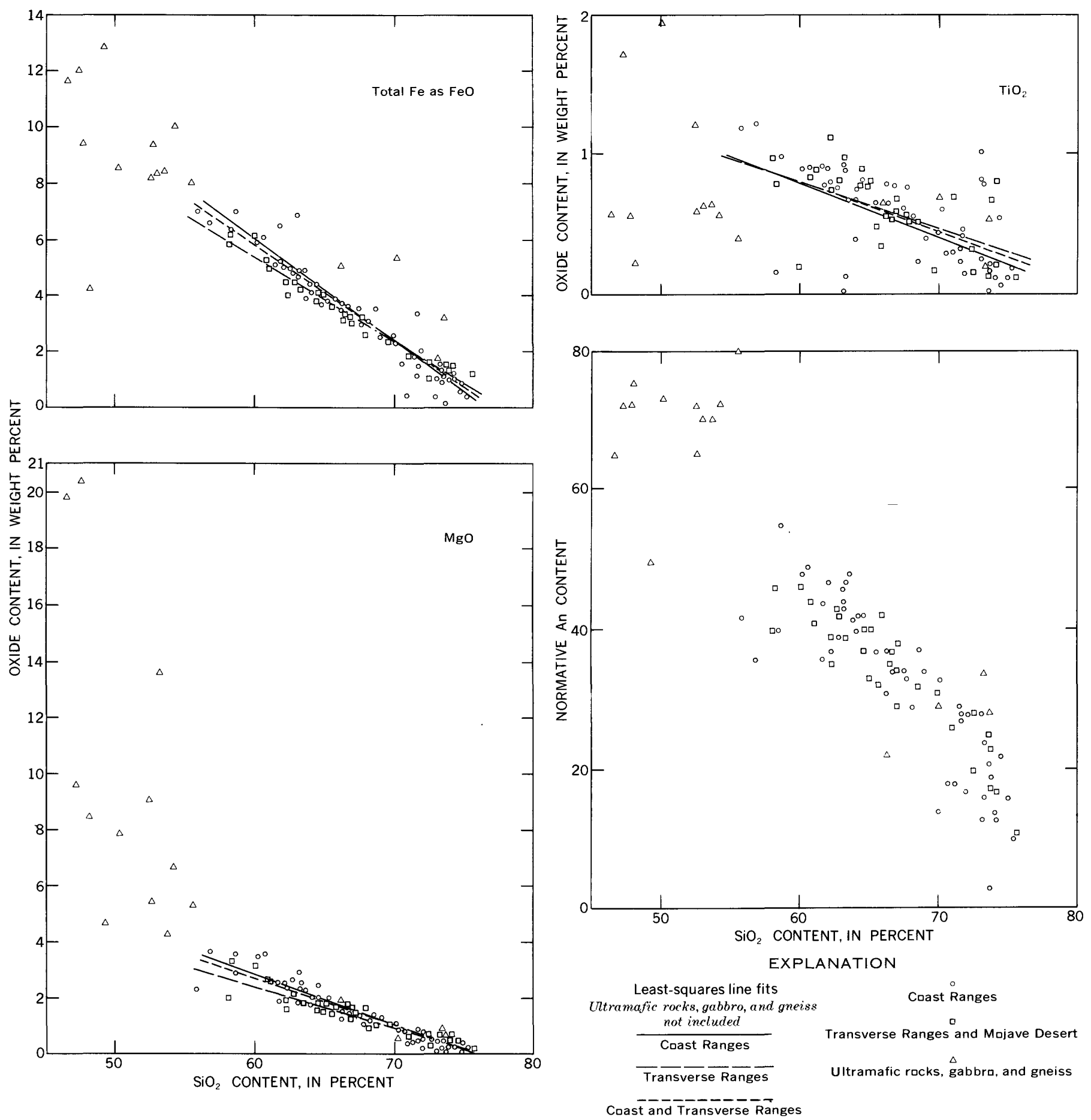

Figure 32.-Continued. 

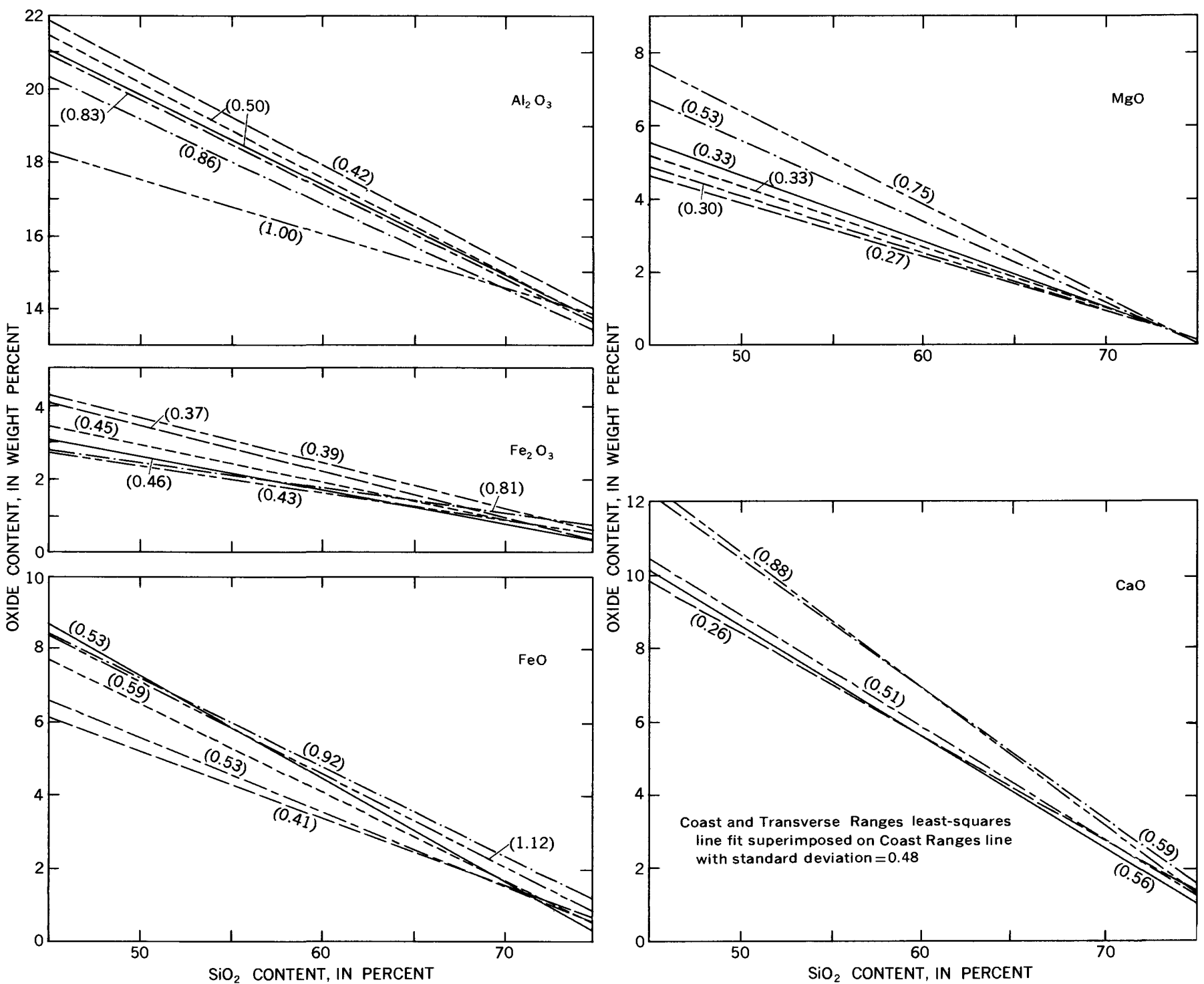

FraURE 33.-Graphs showing least-squares line fits of silica-variation diagram data. Standard deviation shown in parentheses.

These silica-variation data suggest that the Coast and Transverse Ranges have chemical trends distinctly different from those of the southern California batholith and the western Sierra Nevada suite. In fact, the Coast and Transverse Ranges rocks more closely resemble the eastern Sierra Nevada suite but have a slightly higher $\mathrm{Al}_{2} \mathrm{O}_{3}$ and lower $\mathrm{K}_{2} \mathrm{O}$ content.

Another type of variation diagram, the differentiation index, has also been used to show the Coast and Transverse Ranges chemical data (fig. 34). In this diagram the sum of normative quartz, orthoclase, and albite is plotted against weight percentages of the various oxides. Not surprisingly, considering the silicavariation data, these diagrams give exceedingly well defined linear trends (except for the ultramafic rocks). Figure 34 does show that the Coast and Transverse Ranges rocks are a bit richer in $\mathrm{SiO}_{2}$ and a bit poorer in $\mathrm{K}_{2} \mathrm{O}, \mathrm{Fe}_{2} \mathrm{O}_{3}$, and $\mathrm{Na}_{2} \mathrm{O}$ than the averages compiled for granitic rocks by Washington (1917). These variations, though slight, seem relatively consistent, and therefore probably cannot be accounted for solely by comparison of relatively old and new analyses. 

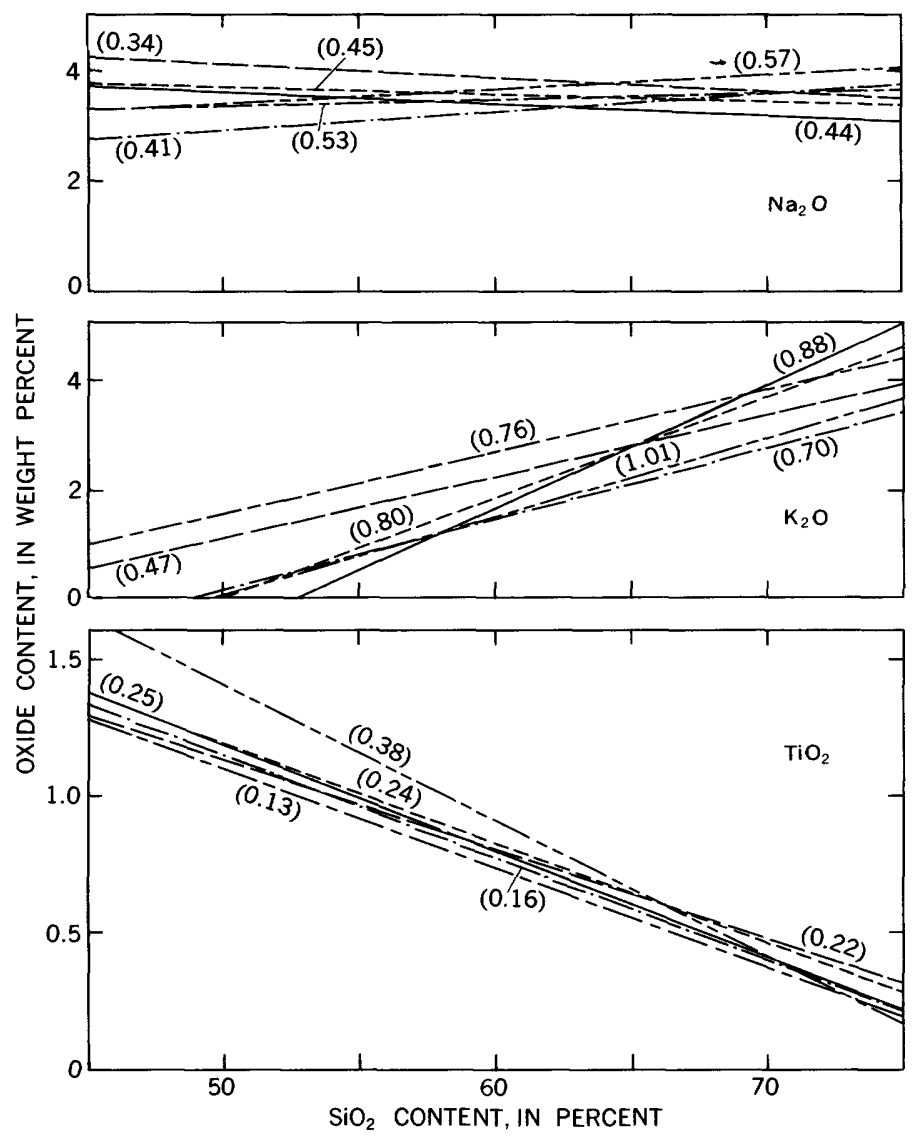

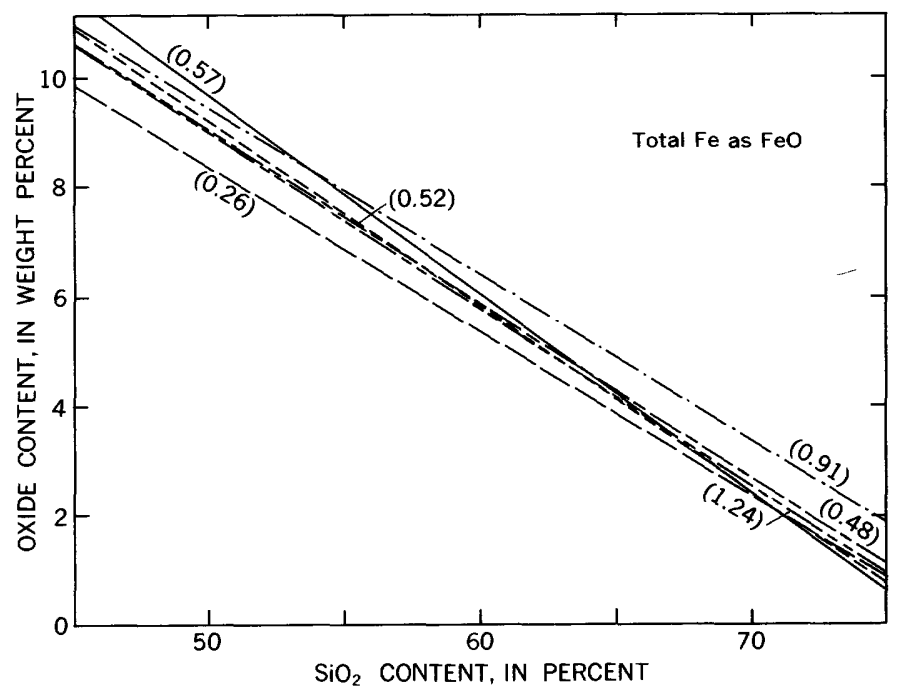

EXPLANATION

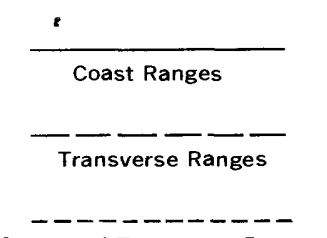

Coast and Transverse Ranges

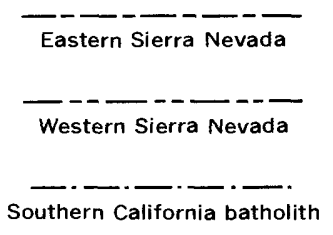

Figure 33.-Continued.

\section{PEACOCK INDEX}

Peacock (1931) observed that the silica value at which the variation diagram curves for total alkalis $\left(\mathrm{Na}_{2} \mathrm{O}\right.$ plus $\mathrm{K}_{2} \mathrm{O}$ ) and $\mathrm{CaO}$ intersect-the alkali-lime indexis a characteristic of rock suites and serves to help classify and distinguish various rock suites. This silica index value, now commonly called the Peacock index, has been calculated for the Coast and Transverse Ranges rocks (fig. 35).

If the ultramafic rocks of the Santa Lucia Range and the gabbro of Gold Hill and Logan are eliminated from consideration, the Peacock index is 59.5 and well within the calc-alkalic class of Peacock (1931). If they are included, the Peacock index is 62.5 , and the suite is calcic. The ultramafic rocks of the Santa Lucia Range also are somewhat problematical because they may be either forerunners of the granitic suite or a separate magmatic series. Both the ultramafic rocks and gabbros have more spread from a trend line than the rest of the "suite," but it is not known with the present data if this spread is significant. If only the Coast Ranges rocks are plotted the Peacock index is more calcic (fig. 36) than if all the samples are plotted (fig. 35).

It is interesting to note that comparative Peacock index values for some other batholithic areas (fig. 37) have affinities with both of the aforementioned Peacock values-59.5 and 62.5 . The eastern Sierra suite is identical, at 59.5, with the Coast and Transverse Ranges suite without the gabbro and ultramafic rocks. On the other hand, both the western Sierra and southern California suites have a calcic Peacock index not far different from the index for all the Coast and Transverse Ranges rock.

It is plain from these data that the bulk of the Coast and Transverse Ranges granitic rocks (quartz diorite to quartz monozonite range) are chemically very similar to the bulk of the eastern Sierra Nevada granitic rocks. It is also clear that the western Sierra and southern California batholith suites have a different character. More important, perhaps, is the fact that this difference is not the result of anomalous mafic rocks that are on 

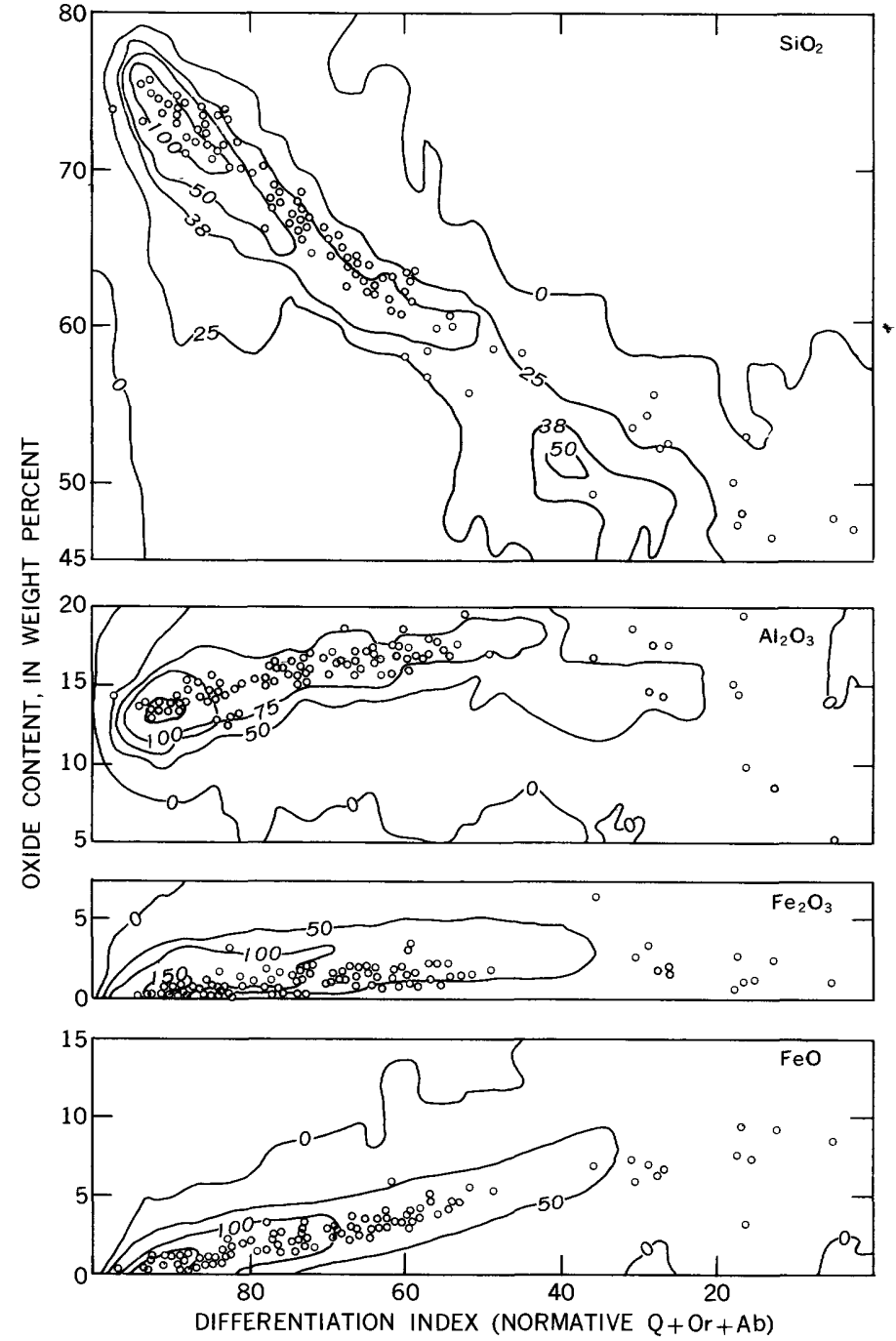
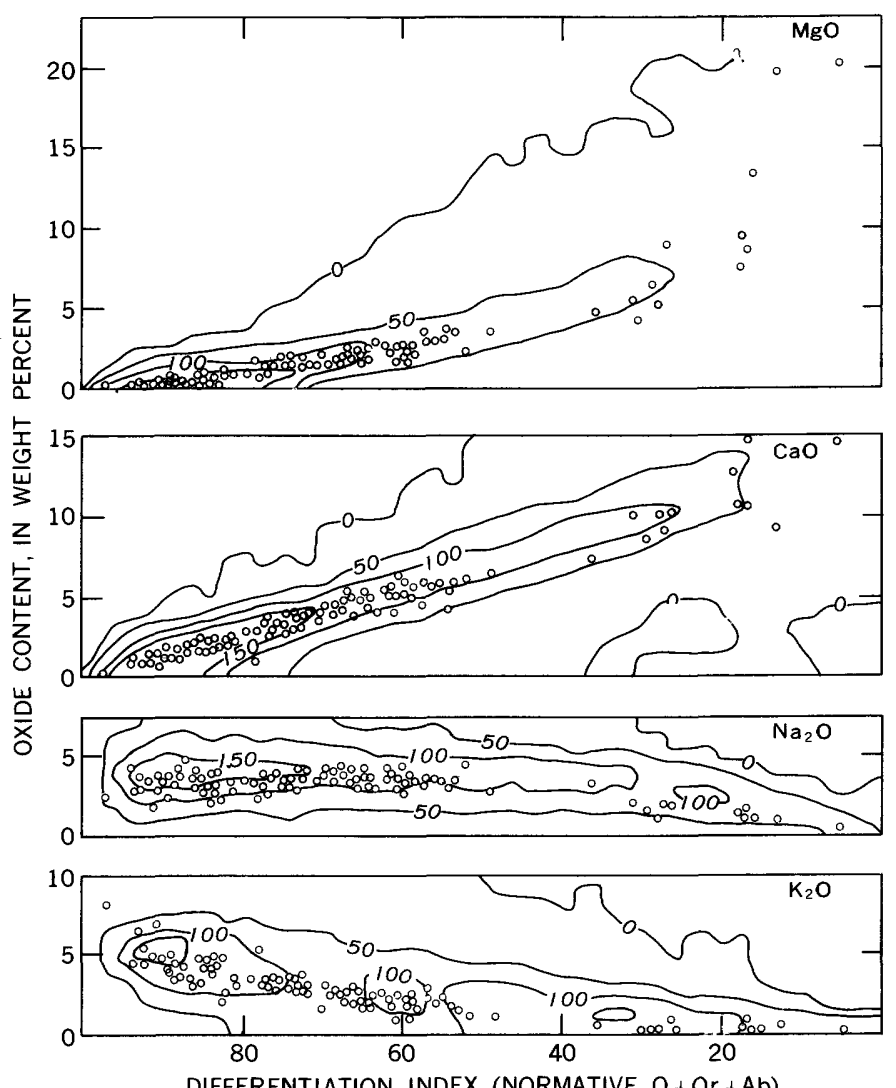

DIFFERENTIATION INDEX (NORMATIVE Q +Or $+\mathrm{Ab}$ )

Note: Contoured background from Thornton and Tuttle (1960, p. 673) who plotted oxide percentage against the differentiation index for 5000 igneous-rock analyses compiled by Washington (1917)

FIgURE 34.-Graphs showing percentage of various oxides plotted against differentiation index. Coast and Transverse Ranges.

different trends from the more silicic rocks. Particularly for the analyzed rocks of the southern California batholith, which have a wide range of silica values in the analyzed rocks, the trend of both alkalis and lime is remarkable consistent throughout the silica range. This tentatively suggests that the highly variable alkali and lime values for the Coast and Transverse Ranges ultramafic rocks and gabbro point to a different mode of origin or a different magmatic suite from the rest of the plutonic rocks.

\section{SELECTED OXIDE PLOTS}

Variation diagrams based on percentages of iron, magnesia, and lime can also be plotted to show trends if the oxides are plotted against each other without the somewhat overpowering presence of $\mathrm{SiO}_{2}$. Total iron plotted against $\mathrm{MgO}$ (fig. 38) shows a generally similar trend for all the suites, but with some subtle differences. The Coast and Transverse Ranges trend suggests more $\mathrm{MgO}$ for any particular iron value, particularly for the rocks low in total iron, compared with the eastern Sierra Nevada suite. Both the western Sierra and southern Califormia suites have similar trends, distinctively different from the Coast and Transverse Ranges trend, that suggest both higher total iron in the more felsic rocks and a larger increase in $\mathrm{MgO}$ relative to iron increase. These trends suggest that the Coast and Transverse Ranges are intermediate between the eastern Sierra and the western Sierra-southern California trend and that they are more closely related to the eastern Sierra in ratio of total iron to magnesia.

Total iron plus $\mathrm{MgO}$ has been plotted against $\mathrm{CaO}$ for the four suites (fig. 39). This ratio does not seem to be useful for distinguishing these suites as all the 


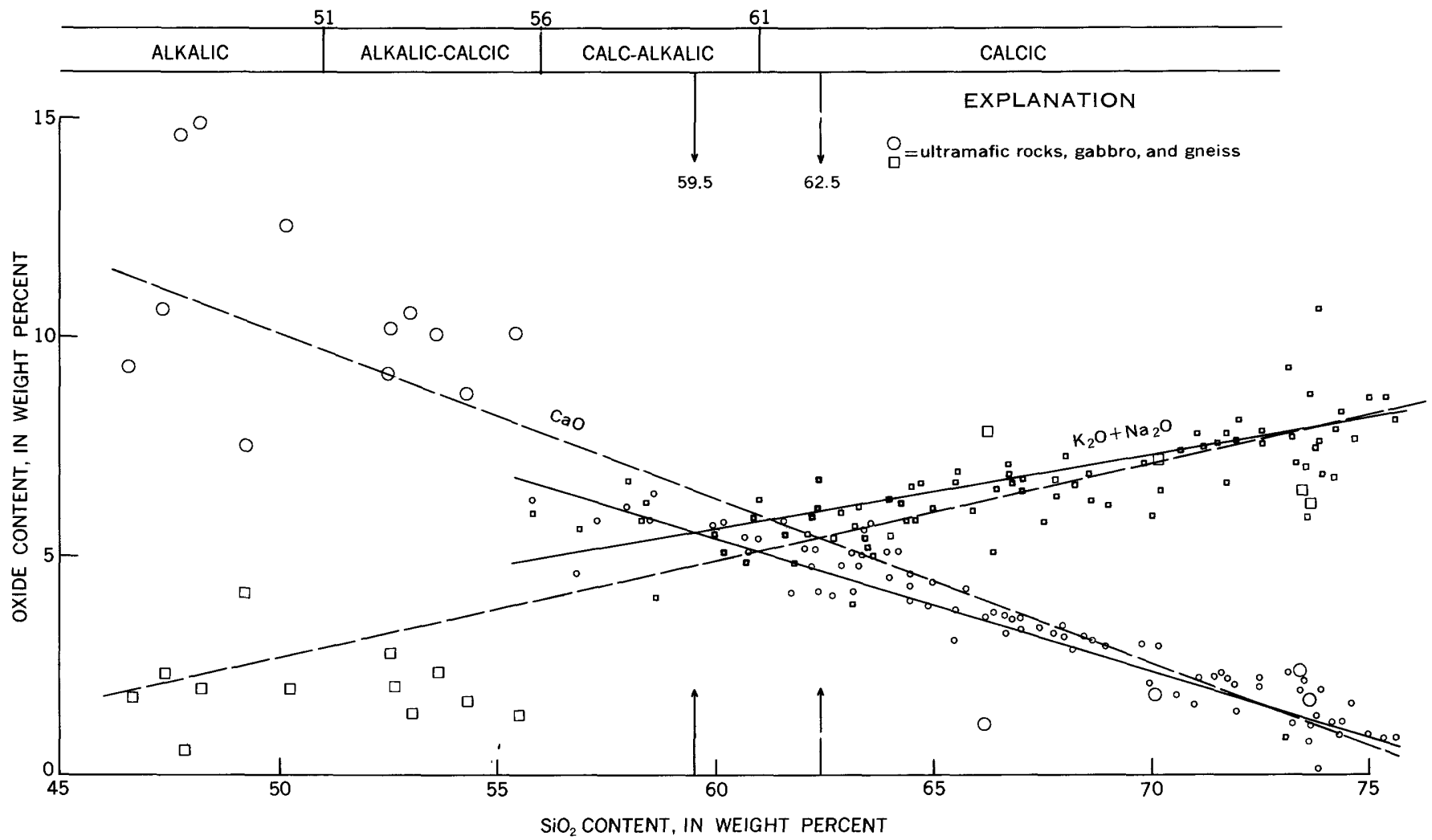

Figure 35.-Graph showing Peacock index of intrusive rocks in the Coast and Transverse Ranges. Solid line, granitic rocks only; dashed line, all rocks including ultramafic rocks, gabbro, and gneiss.

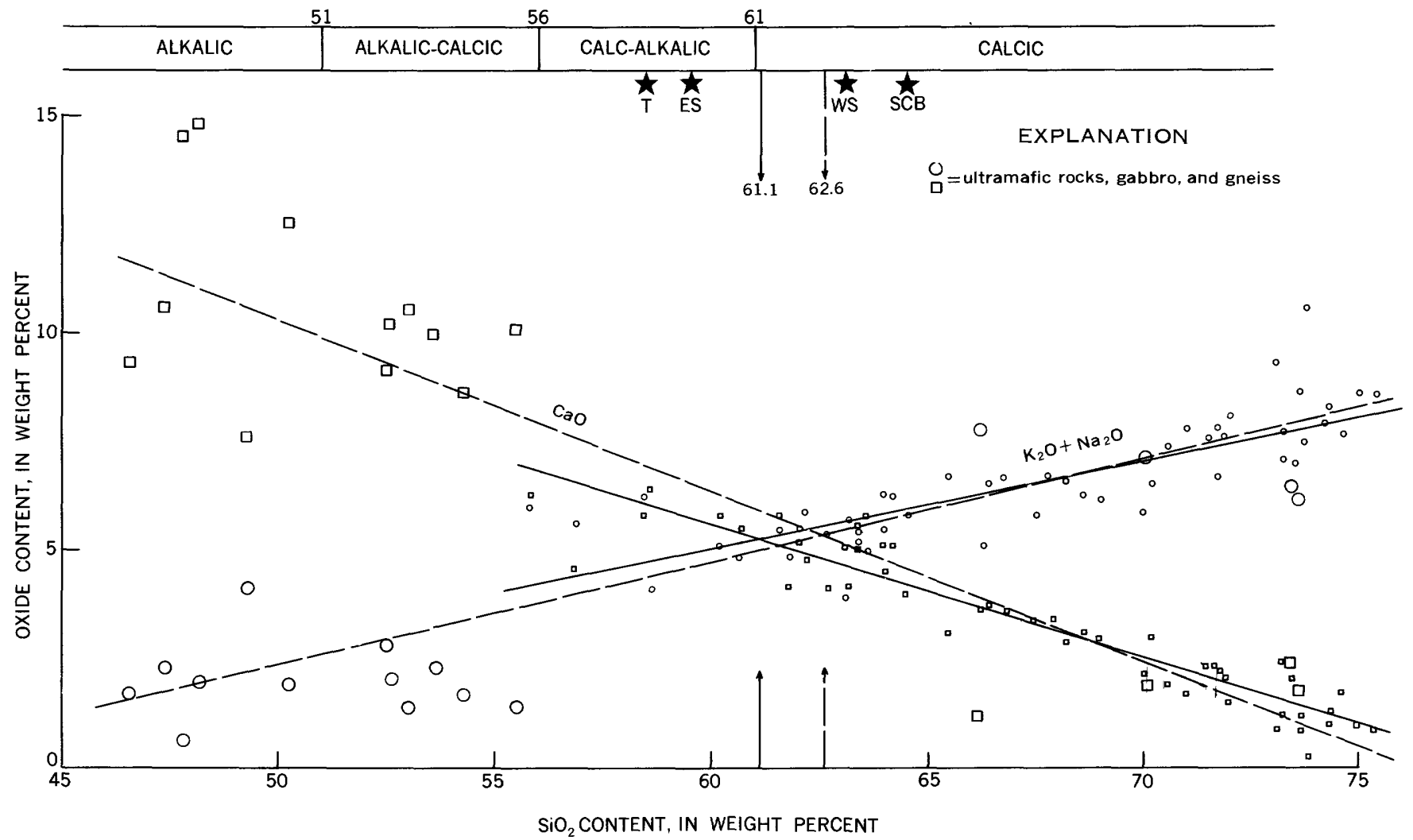

Figure 36.-Graph showing Peacock index of Coast Ranges granitic rocks. Solid line, granitic rocks only; dashed line, all rocks including ultramafic rocks, gabbro, and gneiss. T, Transverse Ranges; ES, eastern Sierra Nevada; WS, western Sierra Nevada; SCB, southern California batholith. 


\begin{tabular}{l|l|l|l}
\multicolumn{2}{c}{51} & \multicolumn{1}{c}{61} \\
\hline ALKALIC & ALKALIC-CALCIC & CALC-ALKALIC & CALCIC \\
\hline
\end{tabular}
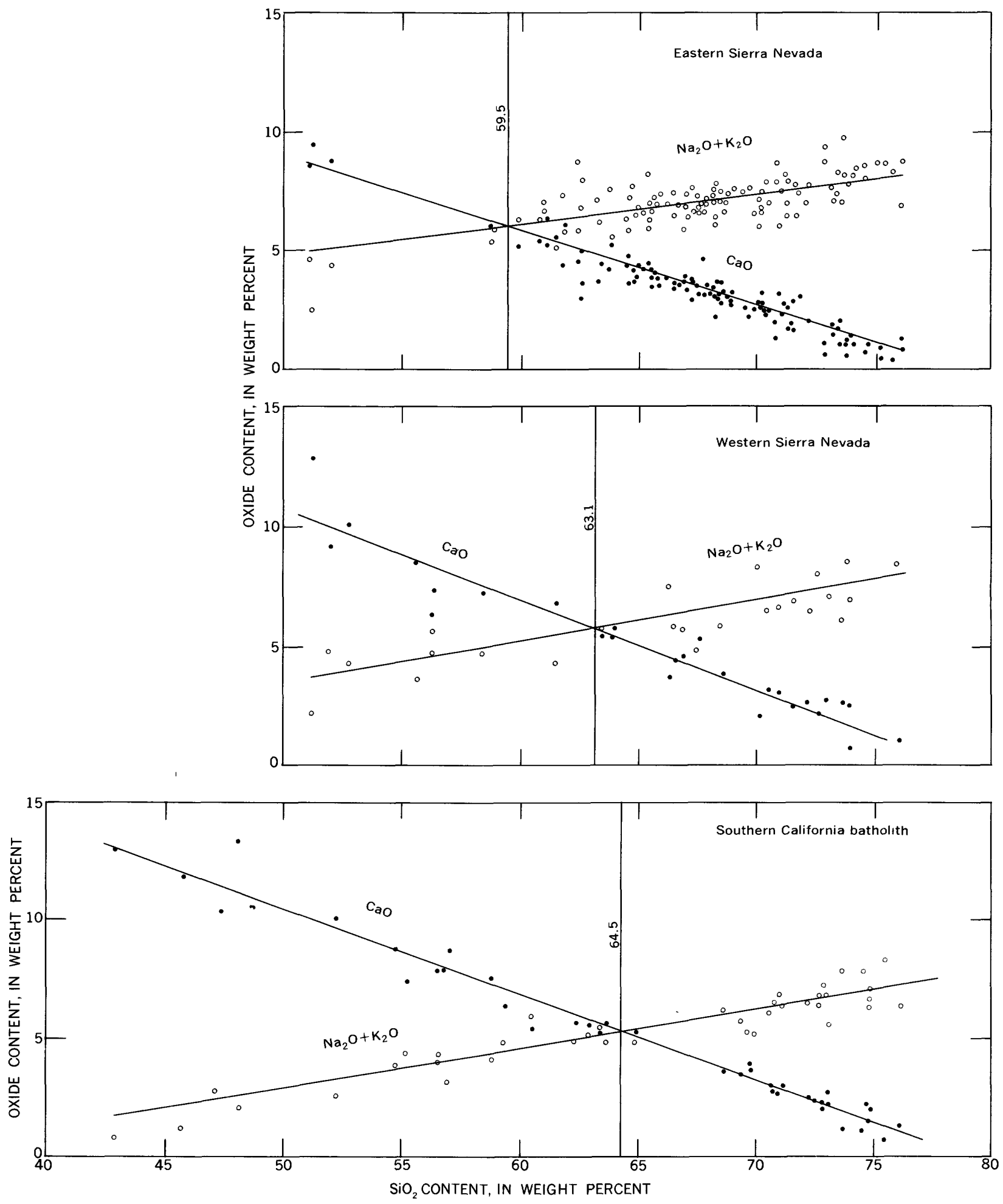

Frgurr 87.-Graphs showing Peacock index of selected batholithic areas. 


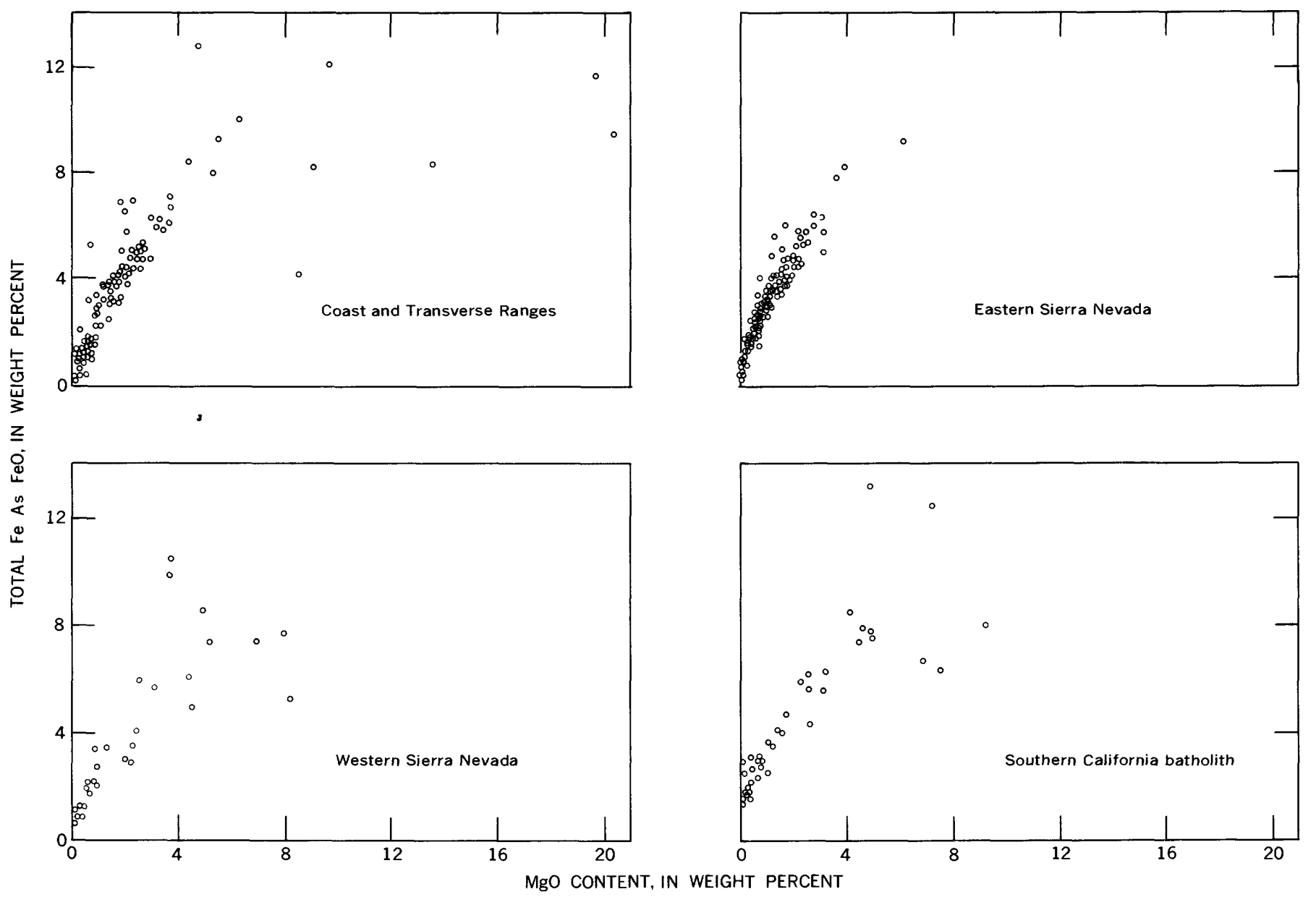

FroURE 38.-Graph showing comparison of percentage of total Fe as FeO plotted against MgO for several granitic suites.
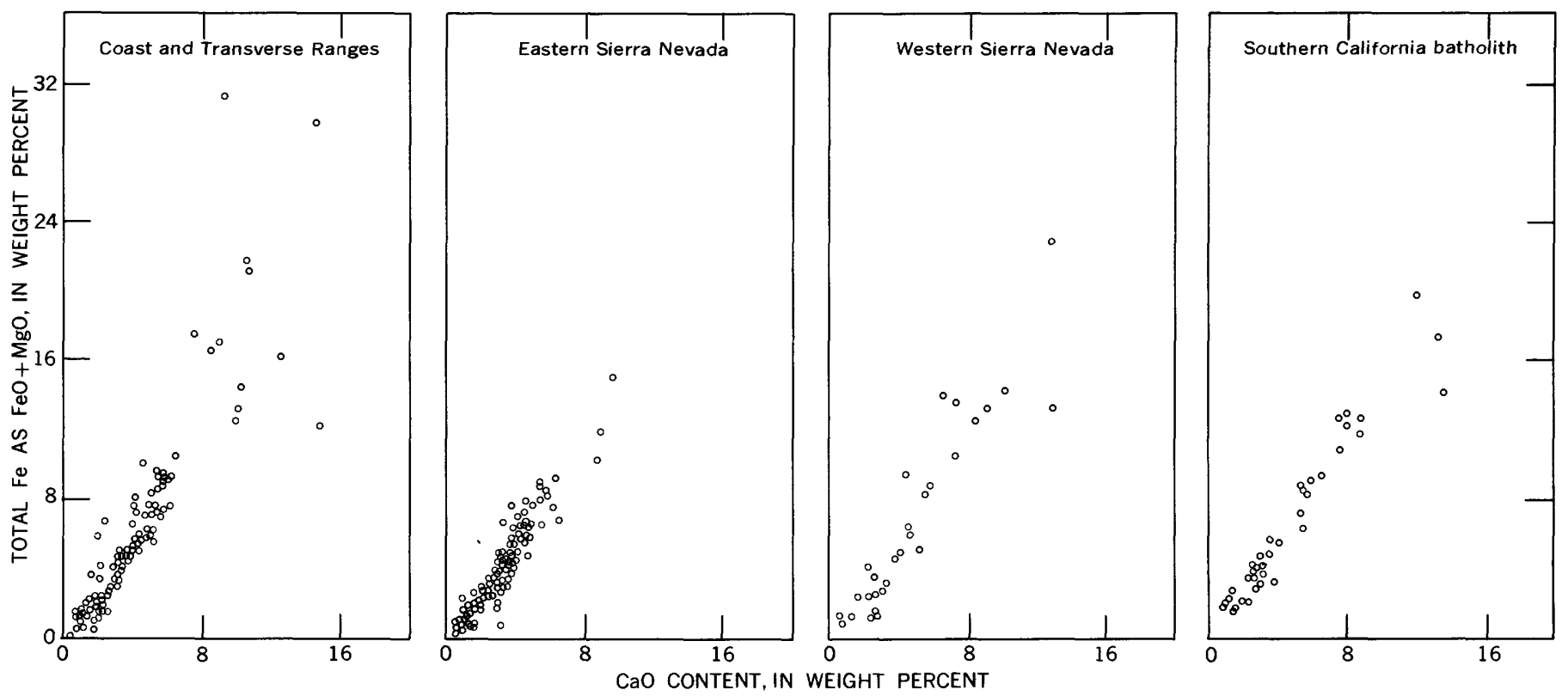

FrgURE 39.-Graph showing comparison of percentage of total Fe as FeO+MgO plotted against CaO for several granitic suites. 
trends are virtually identical. All this plot seems to show is that the Coast and Transverse Ranges rocks are not anomalous compared with other batholithic suites in the California region.

A triangular plot showing the relation between total iron, total alkalis, and magnesia (Alk-F-M diagram) has also been made for these rocks (fig. 40). The Coast and Transverse Ranges rocks show a relatively linear trend in which the iron-to-magnesia ratio remains essentially constant as the total alkalis vary. The very slight bowing of the trend line indicates a minute enrichment in $\mathrm{MgO}$ as total alkalis decrease. This trend is strongly accentuated in the gabbros and ultramafic rocks. The trend of the Transverse Ranges rocks is strikingly linear, and the southern Coast Ranges trend (excluding the gabbro and ultramafics) is virtually the same. The slight bowing seems to be due to the central Coast Ranges rocks. The general trend line of the eastern Sierra Nevada granitic rocks is virtually identical with the main Coast and Transverse Ranges trend. The trend in the western Sierra and southern California batholith suites is about the same for the rocks rich in alkalis relative to iron and magnesia, but both suites seem to be more generally enriched in magnesia in the more alkali-poor rocks.
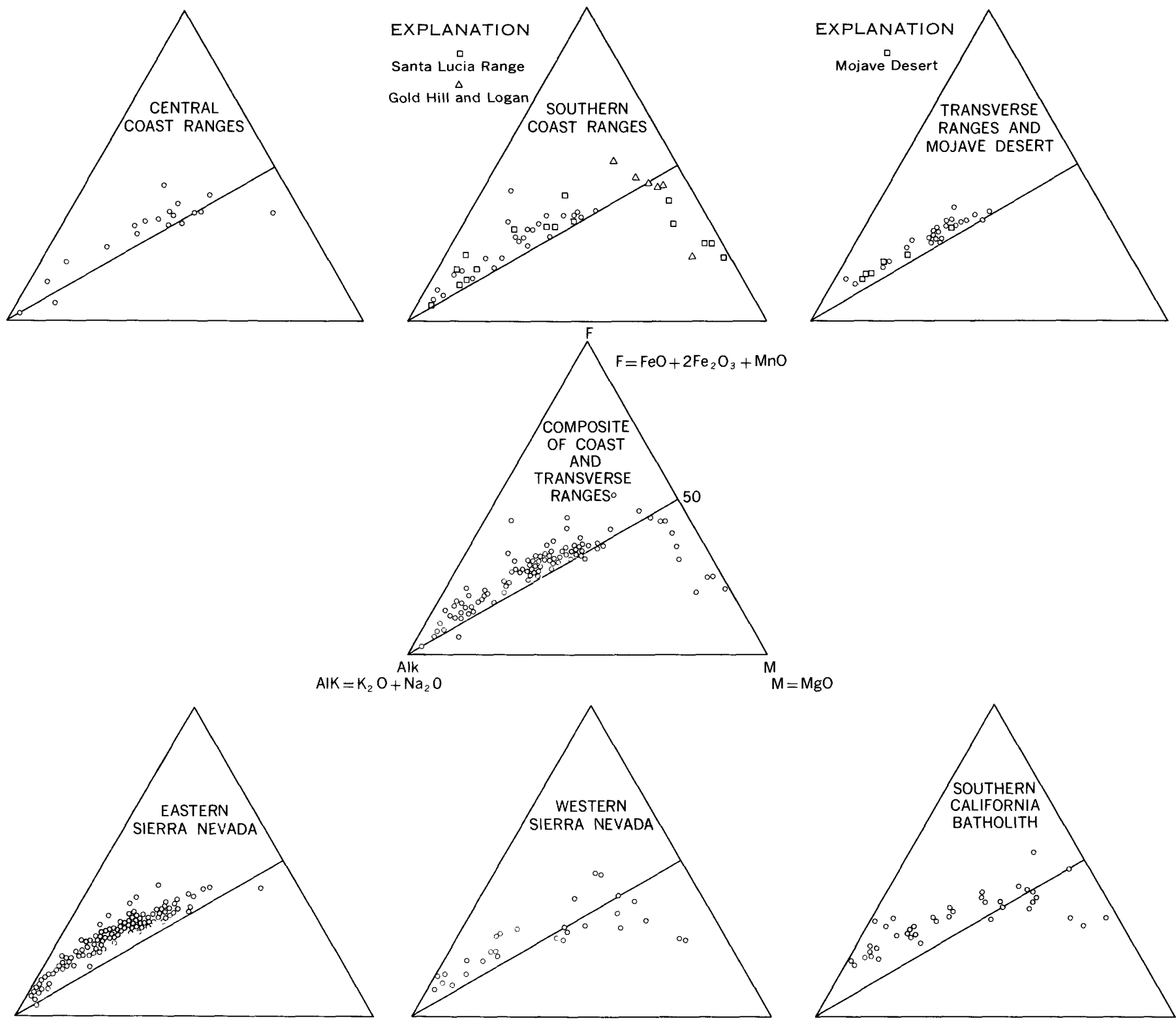

Figure 40.-Plots of Alk-F-M data. 
The Coast and Transverse Ranges rocks have more affinity with the eastern Sierra rocks than with either the western Sierra or the southern California rocks. This relation may be artificial, however. If the eastern and western Sierra plots are combined, the trend for the entire Sierra Nevada very closely resembles the southern California batholith trend.

\section{NORMATIVE MINERAL PLOTS}

One of the most common plots of normative data is the triangular plot quartz $(\mathrm{Q})$, orthoclase (Or), and plagioclase $(A b+A n)$. This gives a normative mineral comparison with the common modal mineral triangular plot (quartz, K-feldspar, and plagioclase). Figure 41 shows these normative minerals plotted for the Coast and Transverse Ranges and some other granitic suites. The overall normative trend is rather well defined through the rocks of intermediate to felsic composition and is somewhat diffuse in the mafic rocks. The contrast between this trend and the comparable modal trend (figs. $3 A, 17 A$ ) is very marked. Whereas in the modal plots, quartz remains abundant throughout the breadth of compositional range from quartz monzonite to quartz diorite, in normative plots quartz falls off sharply as the rocks become richer in normative plagioclase.
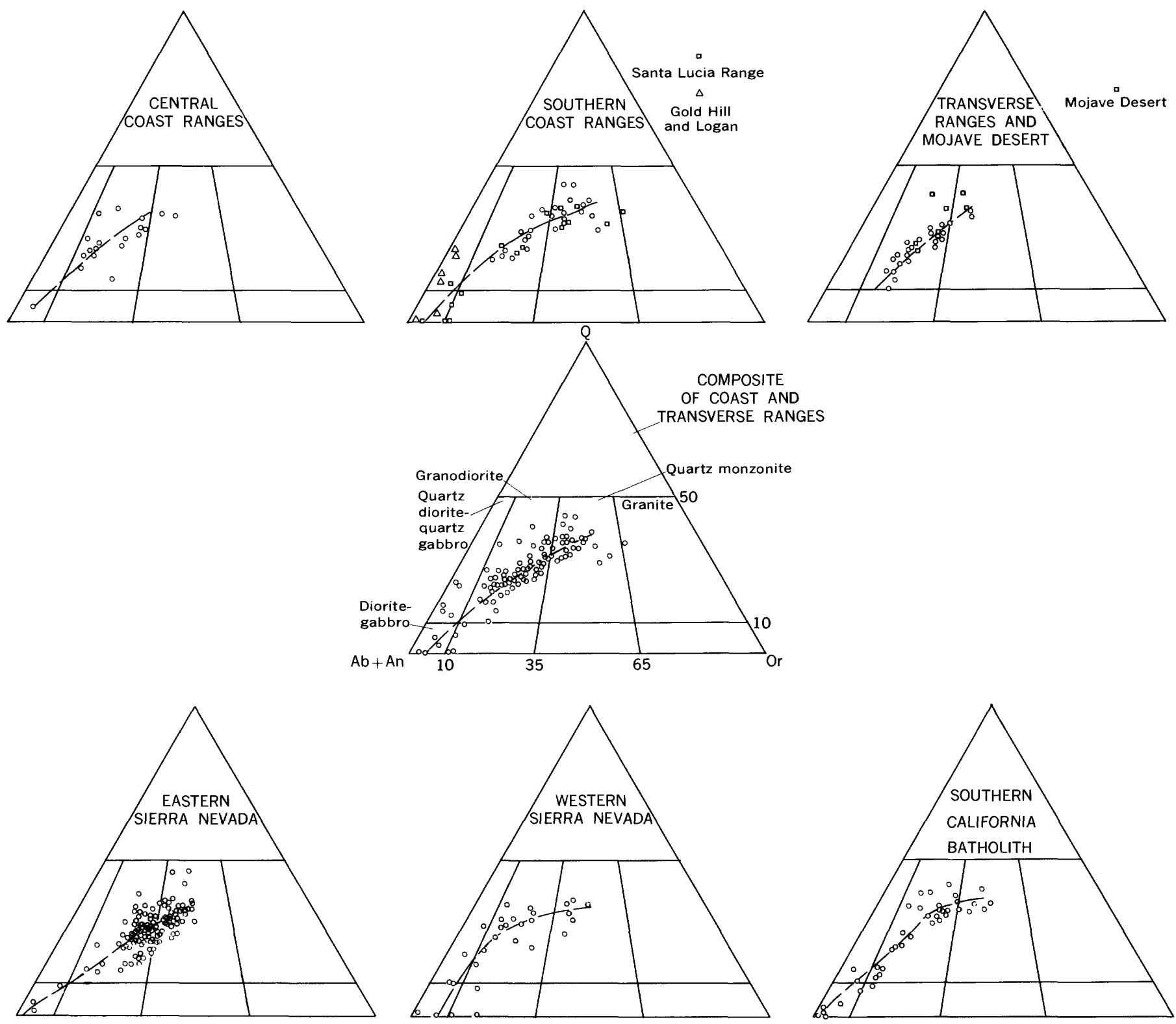

Figure 41.-Plats of normative quartz (Q), orthoclase (Or), and plagioclase $(A b+A n)$. 
From the data available it looks as if the normative trend of the eastern Sierra Nevada rocks is somewhat similar to that of the Coast and Transverse Ranges rocks. The eastern Sierra rocks, however, almost form a bull's-eye cluster over the granodiorite-quartz monzonite boundary ; only a few specimens tail off to the plagioclase corner. If the data from both areas are representative, a different overall chemical pattern is shown by these plots. By contrast, both the western Sierra Nevada and southern California batholith plots (fig. 41) have a humpbacked trend that bows out like the start of a trondhjemitic trend, but then plummets down toward the plagioclase corner. The modal data lead me to ex- pect that the normative trend of the Coast and Transverse Ranges rocks would be more like those of the western Sierra or the southern California granitic rocks, but the similarity to the eastern Sierra rocks is much closer.

Another standard plot of normative data shows the three feldspar components (orthoclase (Or), albite $(\mathrm{Ab})$, and anorthite $(\mathrm{An}))$ on a triangular plot (fig. 42). For the Coast and Transverse Ranges rocks these data make a rather well defined band. They can essentially be superimposed over the similar plots for the eastern and western Sierra Nevada and the southern California batholith with no significant differences. The
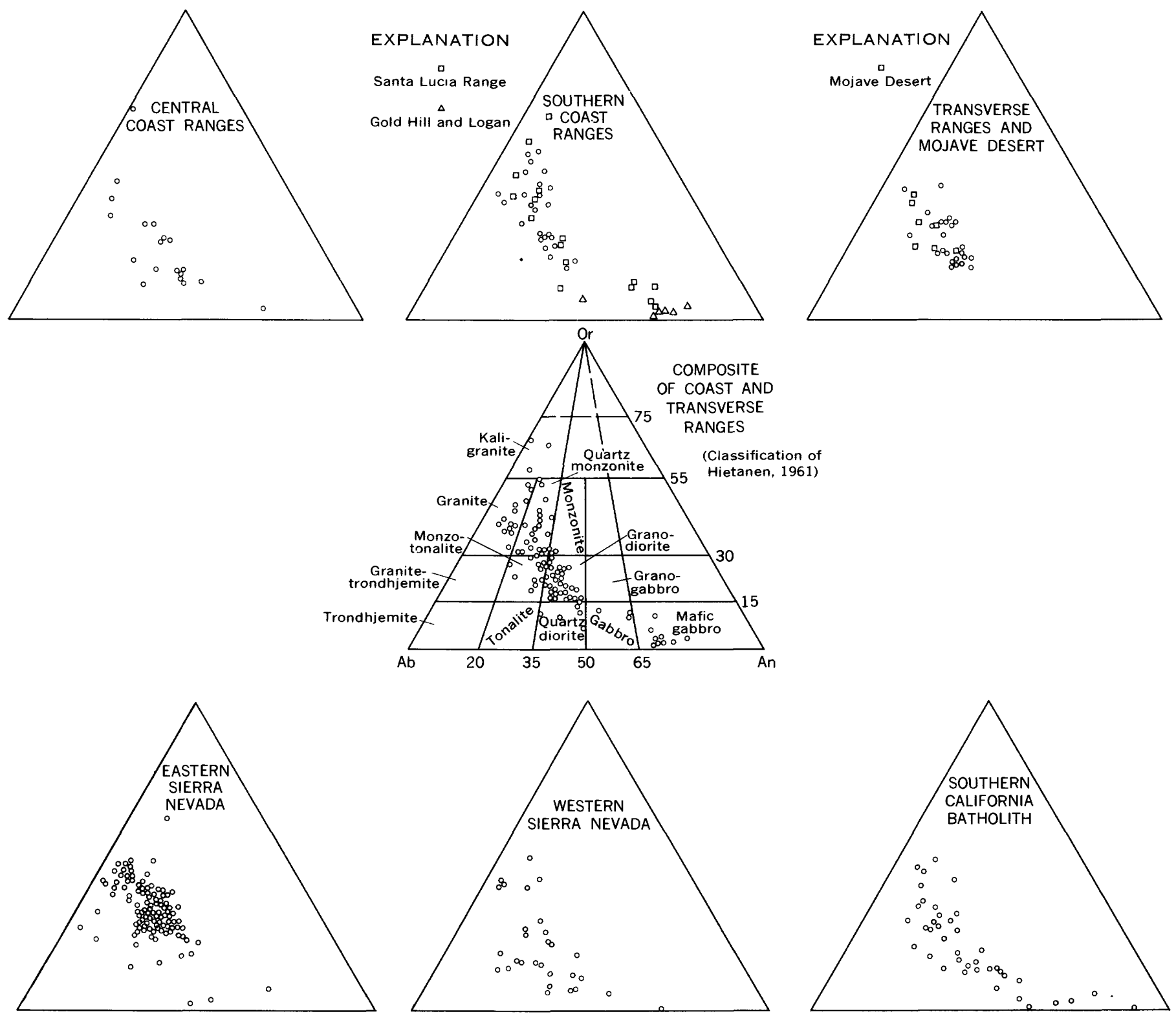

FrguRe 42.-Plots of normative orthoclase (Or), albite ( $\mathrm{Ab}$ ), and anorthite (An). 
western Sierra points are somewhat displaced toward the $\mathrm{Ab}$ corner relative to the Coast and Transverse Ranges points. The southern California batholith points represent about the same compositional range as the Coast and Transverse Ranges points, whereas the eastern Sierra rocks show a marked concentration of somewhat more felsic rocks.

The character of normative feldspar has been used by Hietanen (1961) as the basis for a classification of granitic rocks (shown in fig. 42). I think it is significant that, though the majority of the specimens have the same name that they would have in the modal rock classification used in this report, there are differences. According to the Hietanen classification, a number of the rocks are granite and monzo-tonalite, and very few specimens are in the tonalite or quartz diorite categories. In contrast, the standard modal plot of the chemically analyzed specimens (fig. 43) shows that many specimens are quartz diorite, almost none are granite, and none are syeno-diorite (presumably the equivalent of Hietanen's monzo-tonalite). Some of the Coast and Transverse Ranges rocks have sodic oligoclase and albite plagioclase, but this has all been called plagioclase; in some modal classifications this would be classified as alkali feldspar (in the $\mathrm{K}$-feldspar corner) and would pull some of the quartz monzonite into the granite field. The major difference between the chemical (normative) classification and the modal classification is, however,

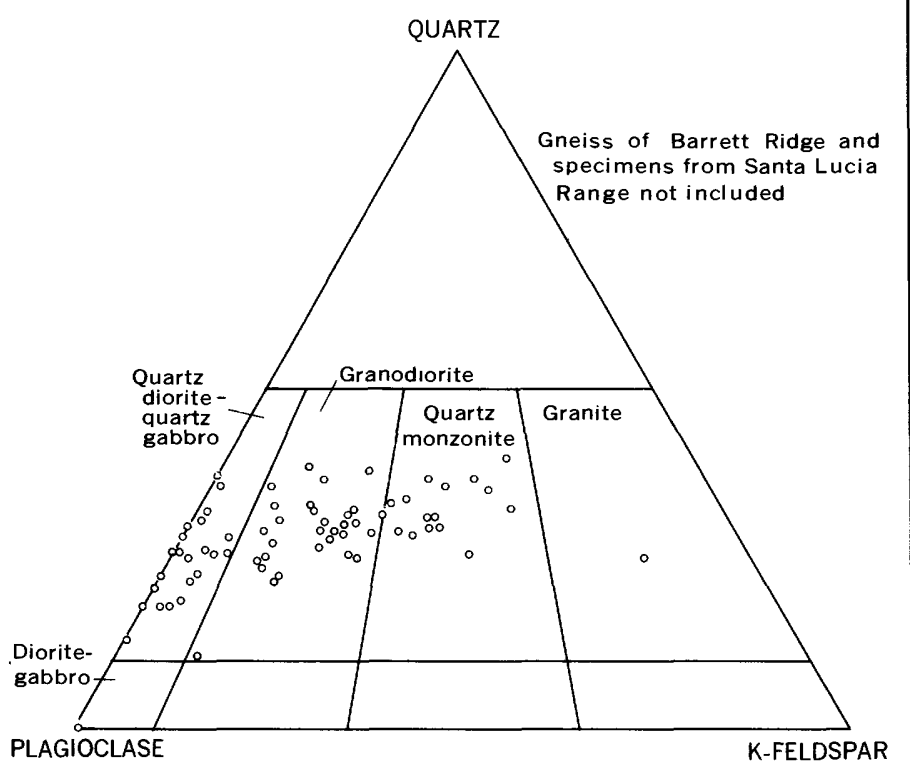

FTgURE 43.-Triangular diagram showing modes of chemically analyzed specimens, Coast and Transverse Ranges. the presence of "monzonitic" rocks and the virtual absense of quartz diorite and tonalite in the normative classification.

Hietanen's normative classification (1961) may be more valuable for rocks with less quartz. The standard modal classification seems to emphasize the relatively quartz-rich character of the rocks of the Coast and Transverse Ranges and other California batholithic areas (fig. 35), whereas the normative classification, which depends on feldspar proportion, does not adequately express this character. Also, the rather pronounced trend of the Coast and Transverse Ranges rocks on the Or-Ab-An diagram does not match the orientation of the normative classification categories. This is equally a problem with the modal classification (fig. 43), although because there are fewer and bigger categories, the modal classification appears less restricting.

Figure 44 shows the expanded faces of the tetrahedron quartz $(\mathrm{Q})$, orthoclase $(\mathrm{Or})$, albite $(\mathrm{Ab})$, and anorthite (An), to which the normative data for the Coast and Transverse Ranges have been projected and plotted separately. Also on this figure are the mineral phases determined by experimental studies. (See Bateman and others, 1963, p. D34, for details of sources.) These two plots show some rather concentrated fields of points for the Transverse Ranges and some scatter (largely because of the gabbro and ultramafic rocks) for the Coast Ranges. There is at least an apparent difference between the two suites. The Coast Ranges rocks trend away from the An corner and then take a rather decided bend toward the Or corner. The Transverse Ranges rocks, contrastingly, do not show this bend. Also, the general trend in the densest part of the field on the $\mathrm{Q}-\mathrm{Ab}-\mathrm{Or}$ face has a significantly different orientation in the two suites. These differences may in part be due to the less varied composition of the Transverse Ranges specimens, but they could also be due to some difference in the crystallization history of the two suites.

\section{TRACE-ELEMENT CONCENTRATIONS}

The concentrations of 44 trace elements were determined by semiquantitative spectrographic analysis of the chemically analyzed specimens (tables 29-31). To show the concentration and range of concentration of those trace elements that occurred in most of the rocks, a histogram was constructed that plotted the occurrences of each semiquantitative step (fig. 45). It should 
be remembered in using these data that the percentage figures along the base of the histogram represent midpoints of the semiquantitative analysis steps; they are not absolute values, but are subject to the limitations discussed in tables 29-31.

Most of the commonly occurring trace elements have concentrations that are comparable with averages in granitic rocks reported by Taylor (1965). Both barium (Ba) and strontium ( $\mathrm{Sr}$ ) are somewhat more abundant in the Coast and Transverse Ranges. Also cerium (Ce) is somewhat higher, but was not found in many specimens. Niobium $(\mathrm{Nb})$ appears to be less common than in Taylor's (1965) averages. Boron (B) is also less common and was below the limit of detectability for most of the southern Coast Ranges specimens.

The range of concentrations is surprisingly limited for some trace elements. For others, those with a considerable range, the concentration was plotted against percentage of $\mathrm{SiO}_{2}$ (fig. 46). These plots show that as trace-element concentrations rise, silica decreases. There appears to be no significant variation in the pattern of trace-element occurrence between the central and southern Coast Ranges and the Transverse Ranges.

\section{AVERAGE CHEMICAL COMPOSITION OF BIOTITE AND HORNBLENDE}

Averages have been calculated for chemical analyses of nine biotite and eight hornblende samples from granitic rocks from the Coast and Transverse Ranges (table 32). These averages and the calculated structural formulas should serve as an index for anyone who wishes to draw generalizations about the chemical and structural character of biotite and hornblende in the granitic rocks of this region but who does not have access to chemical data. The averages, from analyses of coexisting biotite and hornblende, are probably fairly representative of dark minerals of the quartz diorite and granodiorite of the region, but may be less representative of the dark minerals of the more felsic biotite quartz monzonite. The chemical data for the individual minerals, their location, and a discussion of their significance have been reported by Dodge and Ross (1971).

The biotites and hornblendes were obtained from Bodega Head, Montara Mountain, Ben Lomond, and Red Hills in the Coast Ranges, from the Valyermo area on the north slope of the San Gabriel Mountains, from the Cedar Springs area on the north slope of the San Bernardino Mountains, and from the Mojave Desert northeast of Palmdale. Although both hornblende and biotite are present at Cedar Springs, only biotite was analyzed; hence, there is one more biotite than hornblende sample in the average.
TABLE 32.-Average chemical composition and structural formulas for biotite and hornblende in basement rocks of the Coast and Transverse Ranges

[Structural formulas calculated on the basis of $24(\mathrm{O}, \mathrm{OH})$ to the formula unit]

\begin{tabular}{|c|c|c|}
\hline \multicolumn{2}{|r|}{ Average } & Range \\
\hline \multicolumn{3}{|c|}{ Biotite } \\
\hline 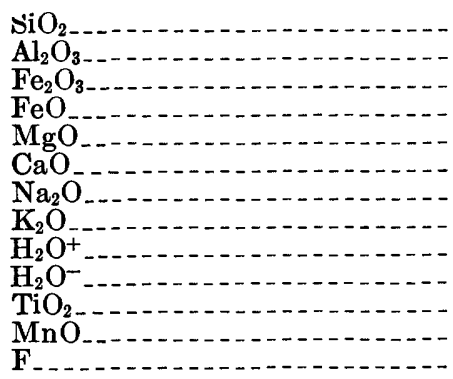 & $\begin{array}{r}\text { 36. } 2 \\
15.8 \\
3.4 \\
16.7 \\
11.4 \\
.6 \\
.2 \\
8.3 \\
3.9 \\
.1 \\
2.8 \\
.3 \\
.3\end{array}$ & $\begin{array}{r}\text { 35. } 36-37.18 \\
15.24-16.43 \\
2.32-4.55 \\
14.95-18.56 \\
9.63-12.34 \\
.27-1.10 \\
7.19-.33 \\
7.52-9.10 \\
3.53-4.33 \\
.07-.29 \\
2.35-3.37 \\
.14-.43 \\
.18-.45\end{array}$ \\
\hline Total & 100.0 & \\
\hline
\end{tabular}

Structural formula for biotite:

$\mathrm{Si}$

$\mathrm{Al}^{\mathrm{IV}}$

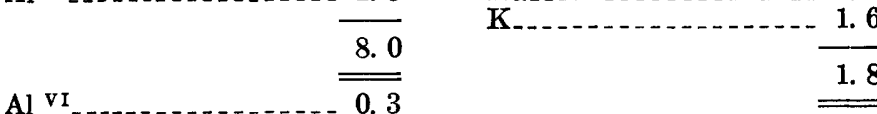

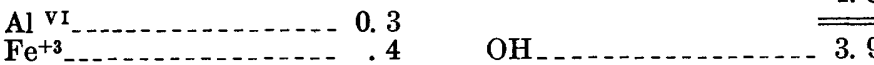

Tín $13 \quad F_{1}$

$\mathrm{Fe}^{+2} \mathrm{~g}^{2}$

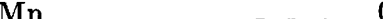

4. 0
5. 1

Hornblende

$\mathrm{SiO}_{2}$

$\mathrm{SiO}_{2}$

$\mathrm{Al}_{2} \mathrm{O}_{3} \ldots$

$\mathrm{Fe}_{2} \mathrm{O}_{3}$

$\mathrm{FeO}$

$\mathrm{MgO}$

$\mathrm{CaO}$

$\mathrm{Na}_{2} \mathrm{O}_{-}$

$\mathrm{K}_{2} \mathrm{O}$

$\mathrm{H}_{2} \mathrm{O}^{+} \ldots \ldots$

$\mathrm{H}_{2} \mathrm{O}^{-}$

$\mathrm{TiO}_{2}$

$\mathrm{P}_{2} \mathrm{O}_{5}$

$\mathrm{MnO}$

$\mathrm{Cl}_{1} \ldots$

F

Total

1. 1

1. 1

.5

. 1

100. 0

41. 73-44. 67

8. $85-11.16$

3. 90-6. 72

12. 24-15. 12

9. $09-10.98$

11. $20-12.09$

1. $01-1.41$

. 82-1. 34

1. $58-1.93$

.03-. 25

99-1. 42

$.02-.35$

.36-. 50

$.03-.09$

$.08-.22$

Structural formula for hornblende:

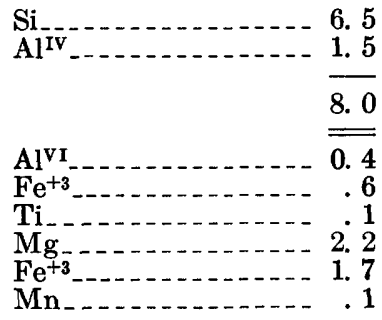

$\mathrm{Ca} \ldots$

$\mathrm{Na}$

$\mathrm{K}$

2. 5

0

4

OH $\ldots \ldots \overline{\overline{1.7}}$

F 
COAST RANGES

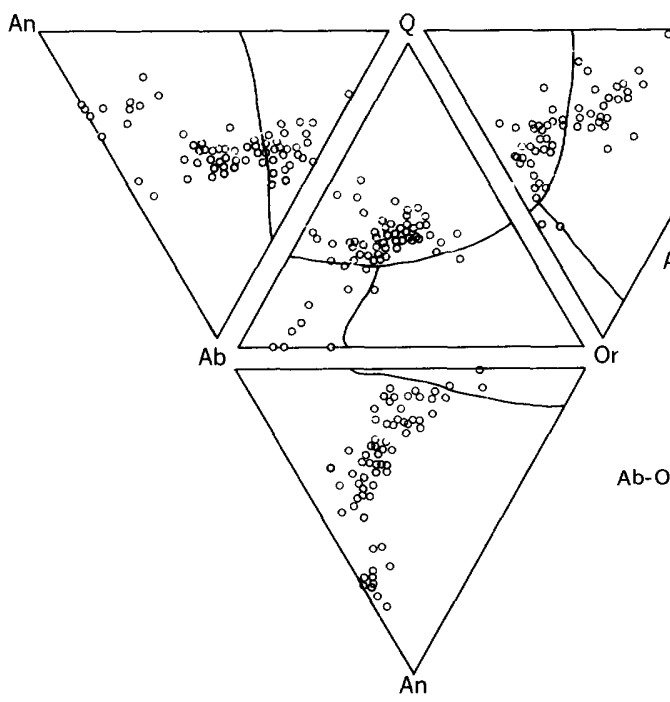

TRANSVERSE RANGES AND MOJAVE DESERT
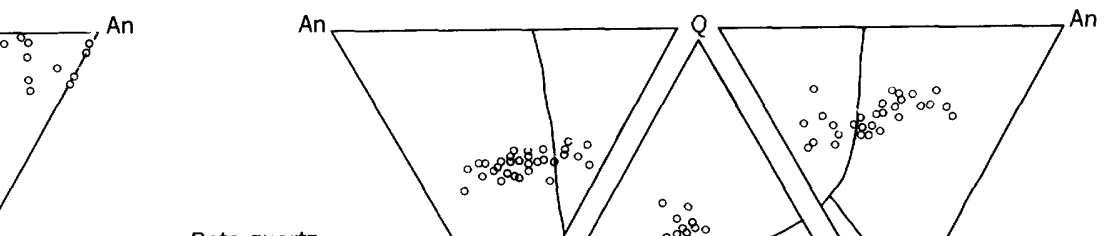
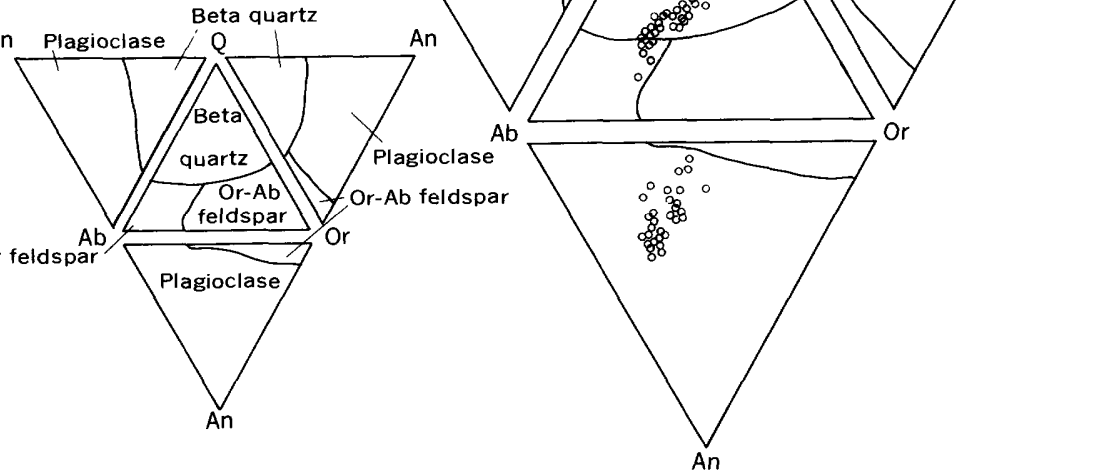

FIGURE 44.- Normative quartz (Q), orthoclase (Or), albite $(A b)$, and anorthite (An) projected to faces of tetrahedron showing mineral phases of the system Or $\left(\mathrm{KAlSi}_{3} \mathrm{O}_{8}\right)-\mathrm{Ab}\left(\mathrm{NaAlSi}_{3} \mathrm{O}_{8}\right)-\mathrm{An}\left(\mathrm{CaAlSi}_{2} \mathrm{O}_{8}\right)-\mathrm{Q}\left(\mathrm{SiO}_{2}\right)-\mathrm{H}_{2} \mathrm{O}$ at 5,000 bars water pressure. (Experimental data from several sources; see Bateman, 1965, p. 105.)

\section{CONGLUSIONS}

As a preface to any concluding remarks, it should be reiterated that the data in this report were collected in a broad reconnaissance sampling of a variety of granitic and gneissic terranes located near the San Andreas fault zone. Also, the basic purpose of this report should be restated here: to assemble these data in a somewhat systematic fashion and to present them as a base for regional interpretation.

Basically, the data have suggested that the great bulk of the Salinian block, except for the gneissic Santa Lucia and Barrett Ridge slices, has a comagmatic granitic basement. From this, it follows that the central granitic core of the Salinian block is relatively coherent. The abundance of rather high-grade quartzofeldspathic gneiss and the migmatitic mixing of granitic material in both the Santa Lucia and Barrett Ridge slices suggest an environment deeper than the central granitic slice, and, hence, differential vertical movement between the slices. Radiometric age dating of biotite and hornblende by the potassium-argon method shows a 70-90-million-year range for both the central granitic slice and the Santa Lucia slice (Compton, 1966, p. 277, fig. 1). The rocks of the Barrett Ridge slice have not yet been age dated. No conclusion can be drawn from the sparse radiometric ages in the Coast Ranges at this time beyond the obvious fact that more dating needs to be done. Other methods should be used to see if this $70-90$ million years is really the age of the rocks or represents an event that has reset the radiometric clock in a suite of rocks of varying age. The present sparse radiometric dates therefore need not mean that the Santa Lucia slice and the central Gabilan-La Panza slice are of the same age. Certainly the gneissic rocks of the San Lucia and Barrett Ridge slices can be any pre-Cretaceous age.

The gross similarity of structural setting and lithology might be interpreted to suggest that these two gneissic slices are related to the gneissic rocks of the Transverse Ranges, which are at least in part Precambrian. Such a comparison and correlation have already been made on the basement-rock map of the United States (Bayley and Muehlberger, 1968). If we accept. large-scale movement on the San Andreas fault system, pieces such as the Barrett Ridge slice could have been slivered off the Precambrian basement terrane to the southeast as the Salinian block slid by. The explanation is not so simple for the Santa Lucia slice, but certainly it is plausible that those gneisses represent a part of the original Precambrian terrane that has differentially risen as the Salinian block slid north, so that gneissic and migmatitic rocks are now superimposed against higher level granitic rocks. This would not necessitate large strike-slip movements on the NacimientoRinconada-San Marcos-Espinosa-Reliz fault zone (pl. 2) to bring the contrasting basements together. The outcrops in the Transverse Ranges and Mojave Desert seem to be more difficult to subdivide structurally, at least from the work that I have done. Part of the difficulty is the more complicated geology and part of it is my less thorough knowledge of much of the Trans- 
PETROGRAPHIC, CHEMICAL STUDY, GRANITIC AND GNEISSIC ROCKS, SAN ANDREAS FAULT, CALIF.

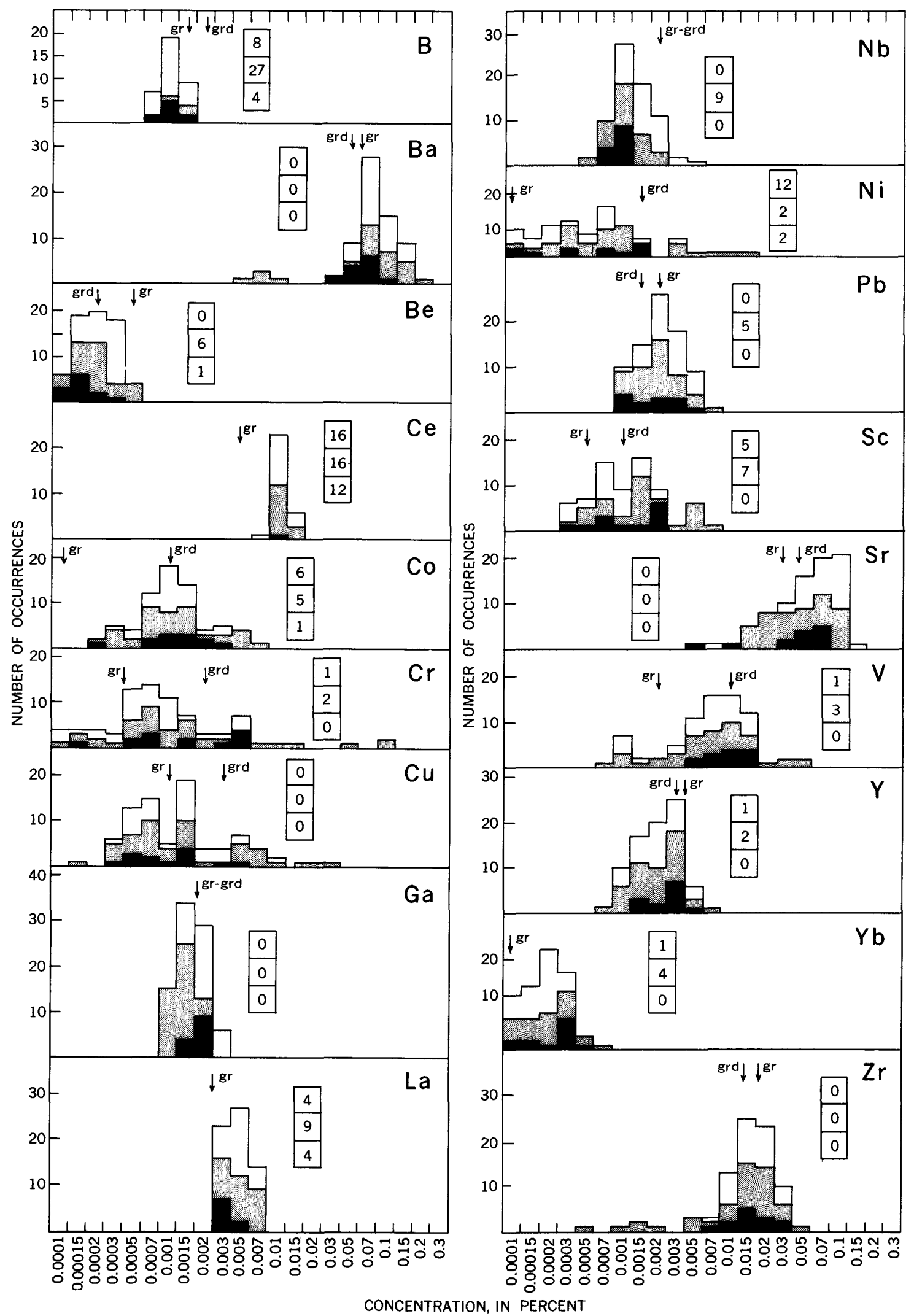

FTGURE 45.-Occurrences of "midpoint" trace-element concentration. (Data from semiquantitative spectrographic analysis.) 
EXPLANATION

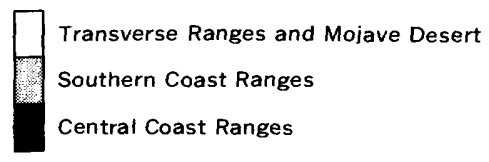

\begin{tabular}{|l|l}
\hline 1 & Transverse Ranges and Mojave Desert \\
\cline { 1 - 1 } 2 & Southern Coast Ranges \\
\cline { 1 - 1 } 0 & Central Coast Ranges
\end{tabular}

Number of occurrences of

"looked for but not found"

\section{grd $\downarrow^{\text {gr }}$}

Average values for granodiorite (grd) and granite ( $g r$ ) are taken from Taylor (1965). Absence of average value indicates information on which to base an estimate is lacking.

Note: Ag, Bi, Mo, Nd not plotted

\section{Frgure 45.-Continued.}

verse Ranges basement. Plate 2 shows this latter point rather well; only selected units have been examined and sampled. In general this region is typified by much gneiss and the migmatitic mixing of gneissic and granitic material. Also it should be noted that whereas no obvious basement rock correlations can be made across the San Andreas fault zone, there is a general similarity of basement rock types on both sides of the zone. For example, high-grade quartzo-felspathic gneiss is common to both sides of the fault zone.

In detail, however, there are striking contrasts across the fault zone. At the west end of the basement outcrops (pl. 2), the gneissic rocks of the Mount Abel-Mount Pinos area that are in part homogenized or ultrametamorphosed to rocks of granitic apperance are in sharp contrast to the homogeneous granodiorite of the Lebec area immediately across the fault to the north. Between these two terranes is a large fault wedge of the Pelona Schist that presumably is a sliver in the San Andreas fault zone. Also north of the fault zone is the block of quartz gabbro, gabbro, peridotite, and hornfels of the Eagle Rest Peak locality. These rocks, separated from the main basement mass of the San Emigdio Mountains by Tertiary rocks, appear to be a unique occurrence in the Transverse Ranges and are possibly related to the Gold Hill and Logan gabbro localities. (See Ross, 1970.)

The Mount Abel-Mount Pinos basement and the granodiorite of the Lebec area are in sharp contrast also to the mixed gneissic and granitic terrane of Frazier Mountain. Extremely coarse and distinctive porphyroblastic gneisses, characteristic of the Frazier Mountain mass, were not found elsewhere in the region. The rather strong contrast, both of rock types and regional structural alinement, between these two areas suggests possible large displacement on the Big Pine fault, yet the fault zone seems to die out to the west.
Some workers have speculated that the Big Pine fault may be the westward continuation of the Garlock fault across the San Andreas fault (Hill and Dibblee, 1953, p. 452-453). Smith (1962) correlated a distinctive dike swarm across the Garlock fault that seems to fix the basement offset on this zone to 40 miles left lateral. The basement rocks in the Tejon block near the Garlock fault are poorly exposed, but those present are clearly distinct from the Lebec type. The geologic relations and significance of the San Andreas-Garlock-Big Pine fault intersection have long been an enigma. My studies have done little to clarify these relations, although they do indicate that there are strongly contrasting basement rock types across all the fault zones in the region of the intersection.

The Frazier Mountain rocks are also notably different from those to the east. Although regional maps do not join the San Gabriel fault and the San Andreas fault (pl. 2), these two faults surely must connect east of Frazier Mountain. The basement-rock contrast between the Frazier Mountain and Liebre blocks necessitates a major structural break. Presumably, the maximum movement on the San Gabriel fault zone to the east is well established at about 13 miles of right-lateral movement by offset on a distinctive contact between gneiss and granodiorite (Ehlig, 1966, p. 60). However, we do not know what movement has occurred on that part of the San Gabriel fault west of where it coalesces with the Sierra Madre fault.

The large fault sliver between the Sierra Madre-San Gabriel fault zones and the San Andreas fault zonethe bulk of the San Gabriel Mountains basement outcrop-contains a distinctive anorthosite and gabbro sequence (Crowell and Walker, 1962). A counterpart of the anorthosite and gabbro complex has been found in the Orocopia Mountains, 130 miles east of the San Gabriel occurrence and on the opposite side of the San Andreas fault zone (Crowell and Walker, 1962).

The rocks that I have sampled along both sides of the San Andreas fault in the segment of this great fault sliver lack distinctive features. The gross resemblance of the granitic rocks of the Holcomb, Fairmont, Liebre, and Bouquet Reservoir masses serves to emphasize the lack of major contrast in basement rocks across the San Andreas fault zone in this segment. Dibblee (1968, p. 263) suggested that the Holcomb-Wrightwood rocks are lithologically and structurally similar to the LiebreBouquet Reservoir rocks. This certainly is a permissible correlation based on the rocks, but I have the same reservation about it that Dibblee expressed: that this correlation would mean a basement-rock offset of 50-60 miles across the same fault zone on which Crowell and 

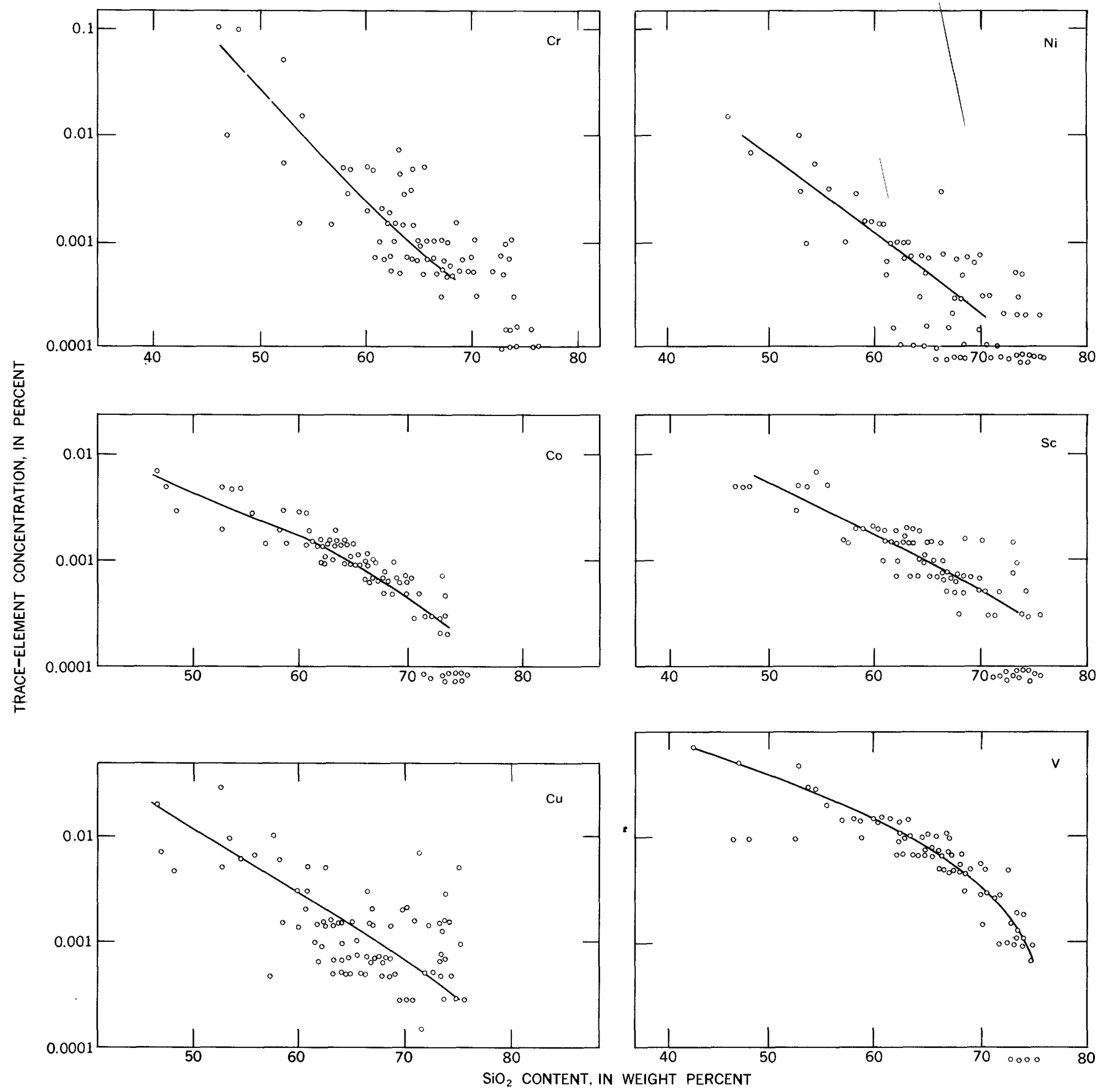

Frgure 46.-Variation of some trace elements with percentage of $\mathrm{SiO}_{2}$.

Walker (1962) postulated a 130-mile offset on the basis of very distinctive anorthositic rocks. Probably the most distinctive petrographic feature of the Wrightwood gneissic rocks is the abundance of coarse euhedral phlogopite plates in the marble layers. These prominent crystals were not seen in the marble in the Liebre-Bouquet Reservoir area, and this seems also to argue against the correlation of those two suites.

The gneissic rocks and lesser granitic rocks of Pinyon
Ridge, though grossly similar to the quartzo-feldspathic gneiss of Wrightwood, seem to have more varieties rich in euhedral hornblende. In addition, marble is absent in these rocks, but rather abundant in the Wrightwood mass. This difference suggests a fault sliver of the Pinyon Ridge rocks between the San Andreas fault and the bulk of the San Gabriel mass.

The mixed gneissic and granitic terrane of the Cedar Springs mass is another example of gneissic rocks north 
of the San Andreas fault zone in the Transverse Ranges. Smaller patches of gneiss are also present in the Mojave Desert basement outcrops to the north.

Plate 2 shows the very small areas that were sampled in the Mojave Desert basement. One very distinctive rock type was found that has not been seen in any other area. This is the augite monzonite of Granite Mountain. This dark-brown-weathering rock, whose alined tabular K-feldspar crystals impart a prominent "trachytic" texture, is presumably an older intrusive included in the felsic granitic rocks of Granite Mountain, but contact relations are not clear. This plutonic mass, however, is small and is found more than 20 miles from the San Andreas fault.

The other Mojave samples provide some idea of the petrographic character of the granitic rocks of the western Mojave, but are too sparse to suggest any correlations. There is a vague resemblance of the Lovejoy and Hi Vista masses to the Gabilan Range granitic rocks, but the rock types are not distinctive or unusual enough to offer more than the vaguest hint of possible correlation. Also the abundant marble bodies of the Gabilan Range have no counterparts in the areas of the Lovejoy and $\mathrm{Hi}$ Vista rocks that I have sampled.

\section{REFERENCES CITED}

Bailey, E. H., Blake, M. C., Jr., and Jones, D. L., 1970, On-land Mesozoic oceanic crust in California Coast Ranges, in Geological Survey research 1970 : U.S. Geol. Survey. Prof. Paper 700-O, p. C70-C81.

Bateman, P. C., 1965, Geology and tungsten mineralization of the Bishop district, California : U.S. Geol. Survey Prof. Paper $470,208 \mathrm{p}$.

Bateman, P. C., Clark, L. D., Huber, N. K., Moore, J. G., and Rinehart, C. D., 1963, The Sierra Nevada batholith; a synthesis of recent work across the central part: U.S. Geol. Survey Prof. Paper 414-D, p. D1-D46.

Bayley, R. W., and Muehlberger, W. R., compilers, 1968, Basement rock map of the United States, exclusive of Alaska and Hawaii : U.S. Geol. Survey, 2 sheets, scale 1: 2,500,000.

Best, M. G., 1963, Petrology of the Guadalupe igneous complex, southwestern Sierra Nevada foothills, California: Jour. Petrology, v. 4, p. 223-259.

Carman, M. F., Jr., 1964, Geology of the Lockwood Valley area, Kerm and Ventura Counties, California: California Div. Mines and Geology Spec. Rept. 81, 62 p.

Chesterman, C. W., 1952, Descriptive petrography of rocks dredged off the coast of central California : California Acad. Sci. Proc., 4th ser., v. 27, no. 10, p. 359-374.

Compton, R. R., 1960, Charnockitic rocks of Santa Lucia Range, California : Am. Jour. Sci., v. 258, p. 609-636.

Compton, R. R., 1966, Granitic and metamorphic rocks of the Salinian block, California Coast Ranges: California Div. Mines and Geology Bull. 190, p. 277-287.

Crowell, J. C., 1952, Geology of the Lebec quadrangle, California : California Div. Mines Spec. Rept. 24, 23 p.

Crowell, J. C., and Walker, J. W. R., 1962, Anorthosite and related rocks along the San Andreas fault, southern Cali- fornia : California Univ. Pubs. Geol. Sci., v. 40, no. 4, p. 219-287.

Dibblee, T. W., Jr., 1967, Areal geology of the western Mojave Desert, California : U.S. Geol. Survey Prof. Paper 522, 153 p. 1968, Displacements on the San Andreas fault system in the San Gabriel, San Bernardino, and San Jacinto Mountains, southern California, in Dickinson, W. R., and Grantz, Arthur, eds., Proceedings of conference on geologic problems of the San Andreas fault system: Stanford Univ. Pubs. Geol. Sci., v. 11, p. 260-278.

Dickinson, W. R., 1966, Structural relationship of San Andreas fault system, Cholame Valley and Castle Mountain Range, California : Geol. Soc. America Bull., v. 77, p. 707-726.

Dodge, F. C. W., and Ross, D. C., 1971. Coexisting bornblendes and biotites from granitic rocks near the San Andreas fault, California : Jour. Geology, v. 79, p. 158-172.

Ehlig, P. L., 1966, Displacement along the San Gabriel fault, San Gabriel Mountains, southern California [abs.]: Geol. Soc. America Ann. Mtgs., San Francisco 1966, Program, p. 60.

Fiedler, W. M., 1944, Geology of the Jamesburg quadrangle, Monterey County, California, in 40th Rept. State Mineralogist: California Jour. Mines and Geology, v. 40, no. 2, p. $177-250$.

Fyfe, W. S., Turner, F. J., and Verhoogen, John, 1958, Metamorphic reactions and metamorphic facies: Geol. Soc. America Mem. 73, 259 p.

Gastil, R. G., 1968, How good is the evidence for 450 miles of offset on the San Andreas fault?, in Dickinson, W.R., and Grantz, Arthur, eds., Proceedings of conference on geologic problems of the San Andreas fault system: Stanford Univ. Pubs. Geol. Sci., v. 11, p. 208-211.

Hammond, P. E., 1958, Geology of the lower Santiago Creek area, San Emigdio Mountains, Kern County, California: M.S. thesis, Univ. California, Los Angeles, 108 p.

Hanna, G. D., 1952, Geology of the continental slope off central California: California Acad. Sci. Proc., 4th Ser., v. 27, no. 9 , p. 325-358.

Hietanen, Anna, 1951, Metamorphic and igneous rocks of the Merrimac area, Plumas National Forest, California: Geol. Soc. America Bull., v. 62, p. 565-608.

1961, A proposal for clarifying the use of plutonic calcalkalic rock names, in Short papers in the geologic and hydrologic sciences, 1961: U.S. Geol. Survey Prof. Paper 424-D, p. D340-D342.

Hill, M. L., and Dibblee, T. W., Jr., 1953, San Andreas, Garlock, and Big Pine faults, California-a study of the character, history and tectonic significance of their displacements: Geol. Soc. America Bull., v. 64, p. 443-458.

Jennings, C. W., compiler, 1959, Geologic map of California (Olaf J. Jenkins ed., San Luis Obispo sheet) : California Div. Mines, scale $1: 250,000$.

Jennings, C. W., and Burnett, J. L., compilers, 1961, Geologic map of California (Olaf P. Jenkins ed., San Francisco sheet) : California Div. Mines and Geology, scale $1: 250,000$.

Jennings, C. W., and Strand, R. G., compilers, 1959, Geologic map of California (Olaf P. Jenkins ed., Santa Cruz sheet) : California Div. Mines and Geology, scale 1:250, 000 . 1969, Geologic map of California (Olaf P. Jenkins, ed., Los Angeles sheet): California Div, Mines and Geology, scale $1: 250,000$.

Johannsen, Albert, 1932, A descriptive petrography of the igneous rocks, v. 2: Chicago, Illinois, Chicago Univ. Press, $428 \mathrm{p}$. 
Koenig, J. B., compiler, 1963, Geologic map of California (Olaf P. Jenkins ed., Santa Rosa sheet) : California Div. Mines and Geology, scale $1: 250,000$.

Larsen, E. S., Jr., 1948, Batholith and associated rocks of Corona, Elsinore, and San Luis Rey quadrangles, Southern California : Geol. Soc. America Mem. 29, 182 p.

Leo, G. W., 1961, The plutonic and metamorphic rocks of Ben Lomond Mountain, Santa Cruz County California: Stanford Univ. unpub. thesis, $169 \mathrm{p}$.

- 1967, The plutonic and metamorphic rocks of the Ben Lomond Mountain area, Santa Cruz County, California: California Div. Mines and Geology Spec. Rept. 91, p. 27-43.

Lofgren, G. E., 1967, Geology of the Mount Pinos basement complex [abs.] : Geol. Soc. America Spec. Paper 115, p. 337.

Loney, R. A., 1970, Faulting in the Burro Mountain area, and its relation to the Nacimiento fault: Geol. Soc. America Bull., v. 81 , p. $1249-1254$.

Loomis, A. A., 1963, Noritic anorthosite bodies in the Sierra Nevada batholith: Mineral. Soc. America Spec. Paper 1, p. 62-68.

MacColl, R. S., 1964, Structural geology of Rattlesnake Mountain pluton Part 1, Geochemical and structural studies in batholithic rocks of southern California : Geol. Soc. America Bull., v. 75, p. 805-822.

Moore, J. G., 1959, The quartz diorite boundary line in the western United States: Jour. Geology, v. 67, no. 2, p. 198210.

- 1963, Geology of the Mount Pinchot quadrangle, southern Sierra Nevada, California: U.S. Geol. Survey Bull. 1130, $152 \mathrm{p}$.

Noble, L. F., 1954, Geology of the Valyermo quadrangle and vicinity, California : U.S. Geol. Survey Geol. Quad. Map GQ-50, scale $1: 24,000$.

Osmont, V. C., 1905, A geological section of the Coast Ranges north of the Bay of San Francisco: California Univ. Pubs. Geol. Sci. Bull., v. 4, p. 39-87.

Pabst, Adolph, 1928, Observations on inclusions in the granitic rocks of the Sierra Nevada: Univ. California Pubs. Geol. Sci. Bull., v. 17, no. 10 , p. $325-386$.

Page, B. M., 1969, Relation between ocean floor spreading and structure of the Santa Lucia Range, California [abs.]: Geol. Soc. America, Cordilleran Sec. Ann. Mtg., Eugene, Oreg., 1969, Abstracts with Programs, pt. 3, p. 51-52.

- 1970, Sur-Nacimiento fault zone in California: Continental margin tectonics: Geol. Soc. America Bull., v. 81, p. $667-690$.

Peacock, M.A., 1931, Classification of igneous rock series: Jour. Petrology, v. 39, no. 1, p. 54-67.

Pearson, R. C., Hayes, P. T., and Fillo, P. V., 1967, Mineral resources of the Ventana primitive area, Monterey County, California: U.S. Geol. Survey Bull. 1261-B, 42 p.

Putnam, G. W., and Alfors, J. T., 1965, Depth of intrusion and age of the Rocky Hill stock, Tulare County, California: Geol. Soc. America Bull., v. 76, p. 357-364.

Reid, J. A., 1902, The igneous rocks near Pajaro: California Univ. Pubs. Geol. Sci., v. 3, p. 173-190.
Rinehart, C. D., and Ross, D. C., 1964, Geology and mineral deposits of the Mount Morrison quadrangle, Sierra Nevada, California: US. Geol. Survey Prof. Paper 385, 106 p.

Rogers, T. H., compiler, 1966, Geologic map of California (Olaf P. Jenkins ed., San Jose sheet) : California Div. Mines and Geology, scale $1: 250,000$.

1969, Geologic map of California (Olaf P. Jenkins ed. San Bernardino sheet) : California Div. Mines and Geology, scale $1: 250,000$.

Ross, D. C., 1958, Igneous and metamorphic rocks of parts of Sequoia and Kings Canyon National Parks, California : California Div. Mines Spec. Rept. 53, 24 p.

1969, Descriptive petrography of three large granitic bodies in the Inyo Mountains, California : U.S. Geol. Survey Prof. Paper 601, 47 p.

1970, Quartz gabbro and anorthositic gabbro-markers of offset along the San Andreas fault in the California Coast Ranges: Geol. Soc. America Bull. v. 81, p. 3647-3662.

Smith, G. I., 1962, Large lateral displacement on Garlock fault, Oalifornia, as measured from offset dike swarm: Am. Assoc. Petroleum Geologists Bull., v. 46, no. 1, p. 85-104.

Spotts, J. H., 1962, Zircon and other accessory minerals, Coast Range batholith, California : Geol. Soc. America Bull., v. 73, p. 1221-1240.

Taylor, S. R., 1965, The application of trace element data to problems in petrology, in Physics and chemistry of the earth, v. 6 : Oxford, Pergamon Press, p. 133-213.

Thornton, C. P., and Tuttle, O. F., 1960, Chemistry of igneous rocks-1. Differentiation index: Am. Jour. Sci., v. 258, no. 9, p. $664-684$.

Trask, P. D., 1926, Geology of the Point Sur quadrangle, California : California Univ. Pubs. Geol. Sci. Bull., v. 16, no. 6, p. 119-186.

Turner, H. W., 1894, The rocks of the Sierra Nevada : U.S. Geol. Survey 14th Ann. Rept., pt. 2, p. 435-495.

Vedder, J. G., and Brown, R. D., Jr., 1968, Structural and stratigraphic relations along the Nacimiento Fault in the southern Santa Lucia Range and San Rafael Mountains, California, in Dickinson, W. R., and Grantz, Arthur, eds., Proceedings of conference on geologic problems of the San Andreas fault system : Stanford Univ. Pubs. Geol. Sci., v. 11, p. $242-259$.

Washington, H. S., 1917, Chemical analyses of igneous rocks published from 1884-1913 inclusive, with a critical discussion of the character and use of analyses : U.S. Geol. Survey Prof. Paper 99, 1201 p.

Wiebe, R. A., 1970, Relations of granitic and gabbroic rocks, northern Santa Lucia Range, California : Geol. Soc. America Bull., v. 81, p. 105-116.

Yeats, R. S., 1968, Rifting and rafting in the southern California borderland, in Dickinson, W. R., and Grantz, Arthur, eds., Proceedings of conference on geologic problems of the San Andreas fault system: Stanford Univ. Pubs. Geol. Sci., v. 11, p. 307-322.

U. S. GOVERNMENT PRINTING OFFICE : $1972 \cdot 0$ - 456- 774 